$$
\begin{aligned}
& 111+171 \%
\end{aligned}
$$

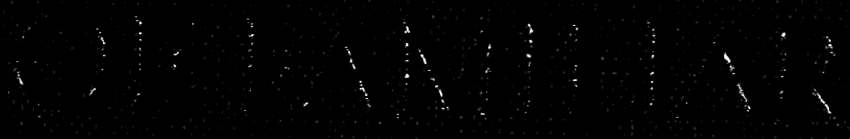

$$
\begin{aligned}
& 1+3 \times
\end{aligned}
$$

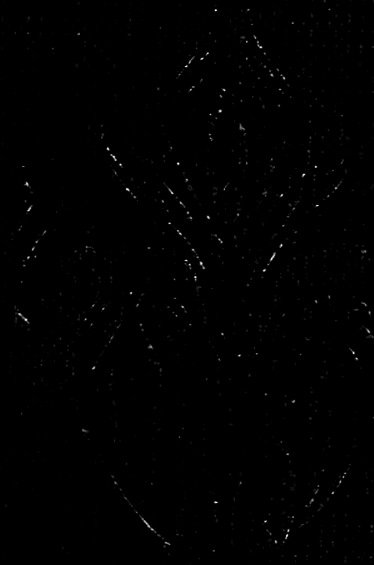



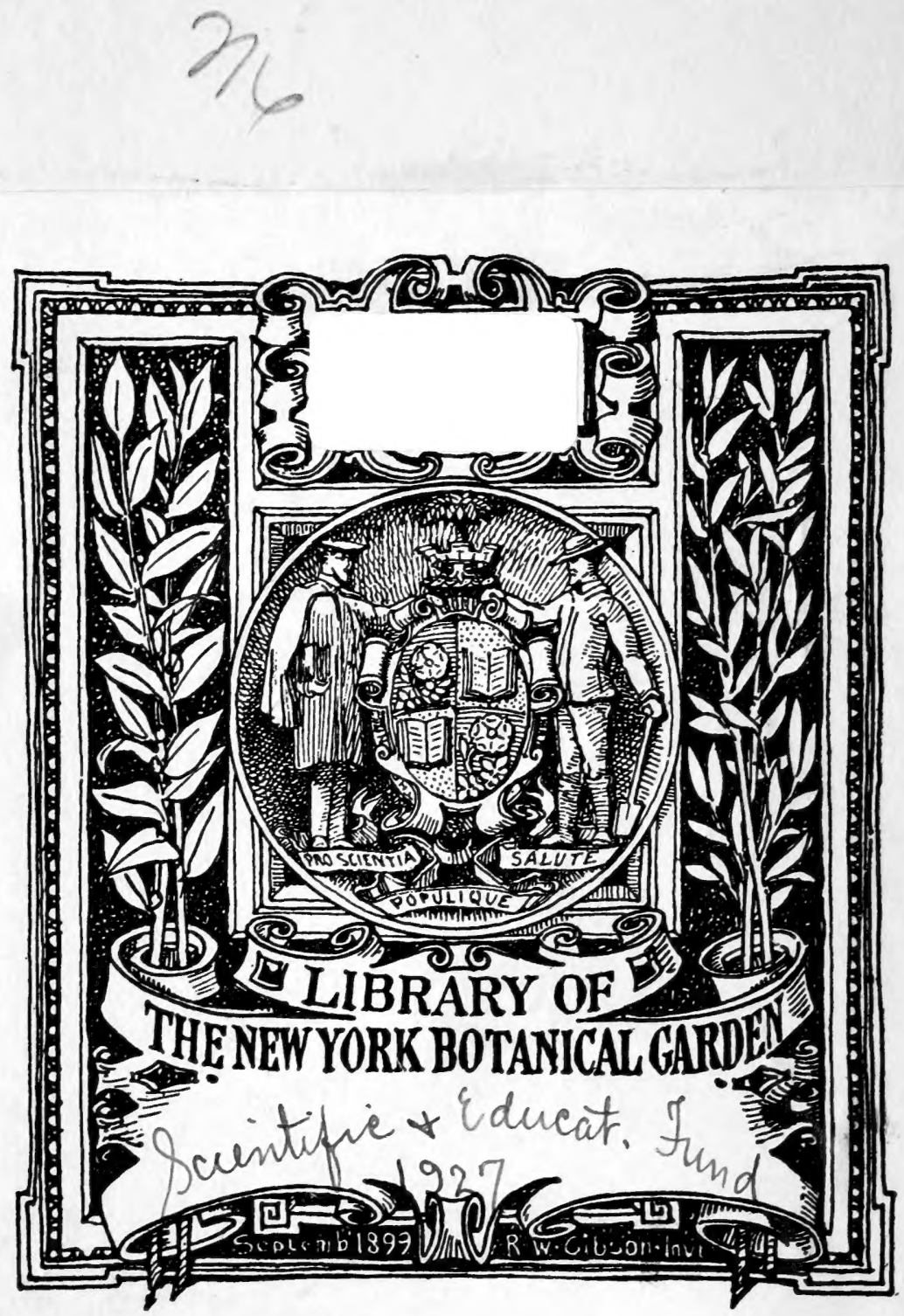


\section{LIFE HISTORIES \\ OF FAMILIAR PLANTS}



Hor

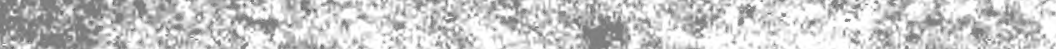
Her a

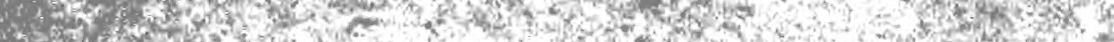
3.7.6.

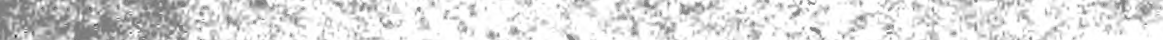

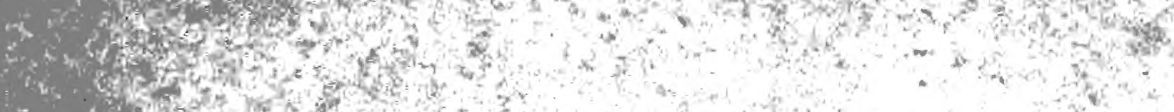

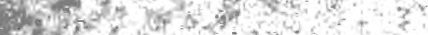

sersese

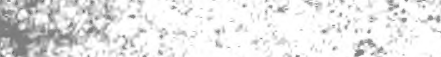

s.

inte

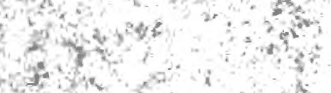

mence

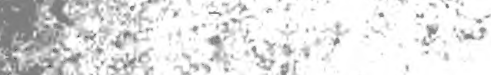

tor 1 w is

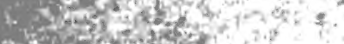

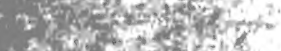

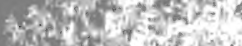

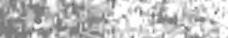

tow

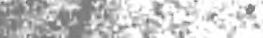

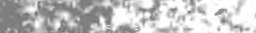

$40 \cos \sin ^{\circ}$

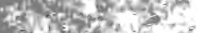

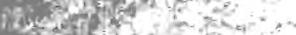

H,

Howe

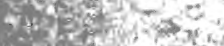

Hes a

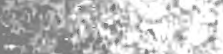

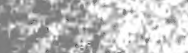

a 1 .

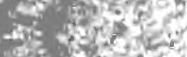

rot 103

$4^{2}{ }^{3} x^{2} x^{2}+y^{2}$

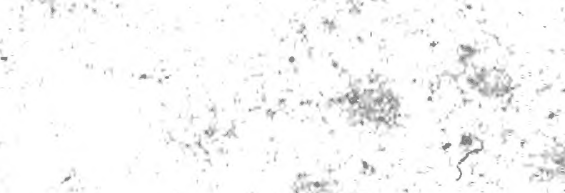

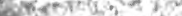

3 ind 5 an

Whex mo

sin 3 .

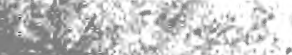

and

$\sin$

(n)

$45 x$

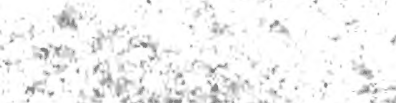

in arososoth

Who 70 in in

Sos os sis

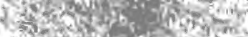

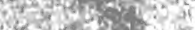
1. x. a 35003

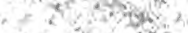

side

$5 \cdot 2+2$

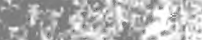

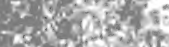

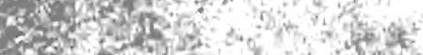

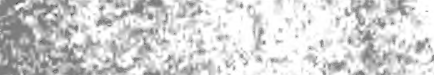

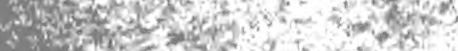

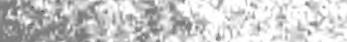

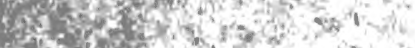

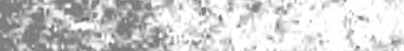

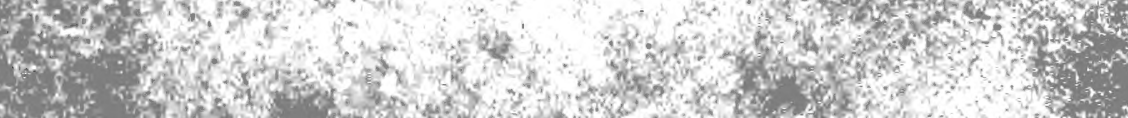

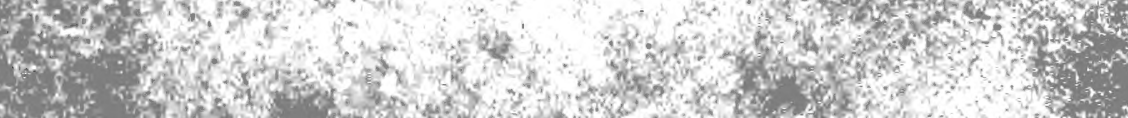

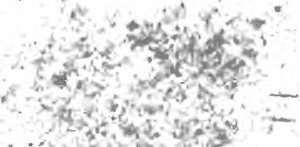

The 20 .

sict

कno 17 . Fa

ir.

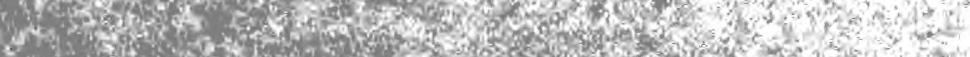

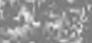

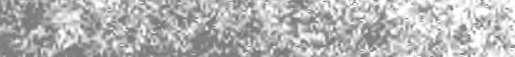

ers.s.

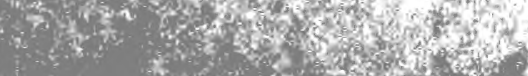




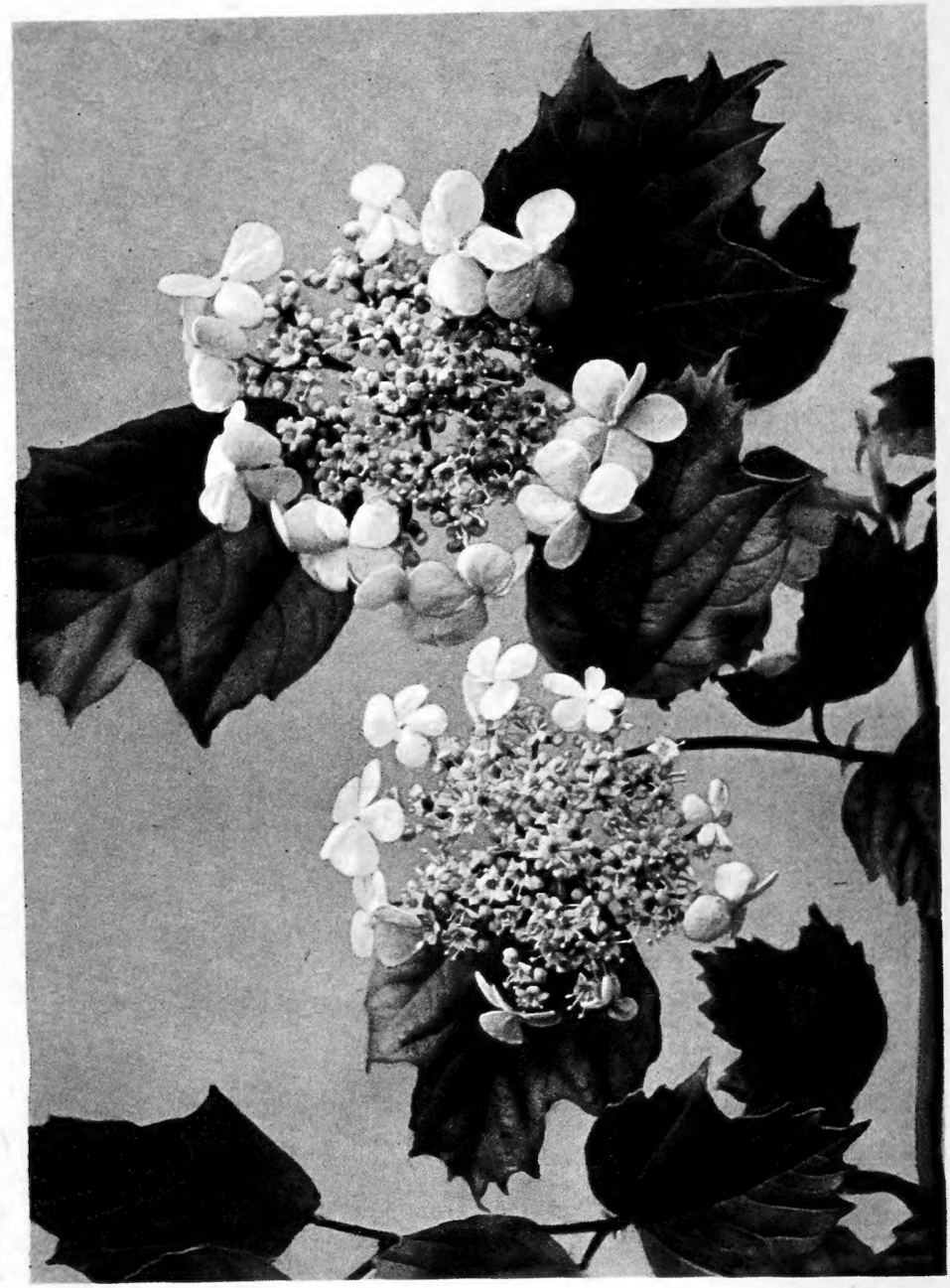

GUELDER ROSE (Viburnum opulus).

The outer flowers of each group are specialised for display, thereby attracting insects towards the insignificant seed-bearing flowers within. 


\title{
LifE Histories
}

OF

\section{Familiar Plants}

\author{
BY \\ JOHN J. WARD \\ Author of "Some Nature Biographies," "Minute Marvels \\ of Nature," "Peeps into Nature's Ways," etc., etc.
}

WITH REMBRANDT FRONTISPIECE AND

I 2 I FIGURES REPRODUCED FROM

PHOTOGRAPHS AND PHOTOMICROGRAPHS TAKEN BY

THE AUTHOR

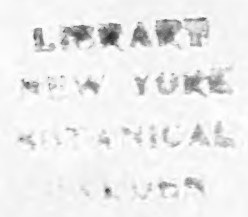

CASSELL AND COMPANY, LIMITED

London, Paris, New York, Toronto and Melbourne MCMVIII 
ALI RIGHTS RESERVED 


\section{P R E FA C E}

THE primary purpose of this book is to assist that large and growing class of non-professional Nature investigators who derive pleasure from seeking the Why and the Wherefore of details in plant structure, and the relationship of these details to animal life. I have, therefore, endeavoured so far as possible to keep clear of technical terminology. Botany, I am well aware, is a science associated in the popular mind with hard names, and is often for that reason regarded by many as uninteresting and dry-asdust. In this volume my effort has been to show that plant life has a very considerable human interest, and that the technicalities of the subject need not disturb the leisure-moment investigator, but can well be left for the use of the botanist and scientist.

In the various chapters I have taken familiar plants almost haphazard from field and garden, and, by the aid of the generally recognised principles of evolution, I have attempted to read the meaning of their diverse forms and details. As some of the later chapters presuppose an 


\section{PREFACE}

acquaintance with the earlier, the non-botanist will be well advised to read them in the order placed, but for those who have already some knowledge of botany this sequence is immaterial.

In a work of this class it would be folly for the author to pretend to originality, for he would be courting disaster to ignore the recognised working hypotheses and valuable suggestions of such authorities as Darwin, Kerner, H. Müller, Sprengel, Grant Allen, Lubbock (Lord Avebury), Ogle, Wallace, Spencer, and others. The foundation of this volume is necessarily laid on the work of previous inquirers.

Nevertheless, the author of a book or this character should not shrink from offering suggestions on points which appear to have been overlooked or ignored by previous writers; and therefore, while the various plants treated of were under my consideration, I attempted to explain the meaning of any structure, or any aspect in their economy, that seemed to present a hitherto unsolved problem. Why are the leaves of the wild orchid spotted? Why is it that the wild camomile opens wide its flowerhead at night, and the similar inflorescence of the field daisy closes? Why do the stonecrops still retain the parts of their flowers in whorls of five? These inquiries represent the class of 


\section{PREFACE}

problem referred to. Each chapter will be found to contain suggested solutions.

In the chapter on "Sensitive Plants" many of the principles of the mnemic theory, and the inheritance of acquired characters, promulgated by Dr. Francis Darwin in his Presidential address to the British Association on September 2nd, I908, are, apparently, largely implied; although at the time the address was delivered the book was being printed.

Regarding the illustrations, the publishers have spared no expense; all are printed from blocks prepared especially for this volume.

If this book serve to encourage Nature lovers to pursue their investigations into her secrets on their own account, and help to direct them to that end, and if at the same time (by means or the numerous illustrations) it bring to the towndweller a breath of the country, its author's object will have been attained.

$$
\text { J. J. W. }
$$

Rusinurbe House, Coventry,

September, Igo8. 



\section{CONTENTS}

\section{CHAPTER I}

THE WILD CAMOMILE (Matricaria Chamonilla):

\section{A WEED OF EMINENCE}

The Advent of the Camomile-On the Rubbish Heap-A

Veritable Sea of Daisy Blooms-Eminence in Rank-Its

Relations-The Daisy-like Inflorescence under a Magnify. ing Lens-Primitive Flowers-Insects and Pollen-Nectar -Plants the First Advertisers-Specialisation for Insect Visitors-Origin of Petal--Saving the Time of the Busy Bee-Fertilisation-Why Daisies are so Lasting as Cut "Flowers"-The White Florets-Mimicry of a FlowerFoliage-Difference in the Behaviour of the Camomile and Field Daisy at Night

\section{CHAPTER II}

\section{THE SYCAMORE "KEY"}

The Boisterous Wind and the Sycamore Tree-Its Seeds or "Keys"-Provision for its Offspring-Dispersion of the Seeds-How they came to Utilise the Wind-Germination of the Seed-The Young Root and the Nurse-leavesFirst Pair of True Leaves-Buds and Branches-The Pendent Stalk of Flowers-A Veritable Flies' PicnicFlowers a Fly Speciality-The Scheme for PollinationUnisexual Flowers and Cross-fertilisation-Hairs from * 


\section{CONTENTS}

the Body of the Bee- "Keys" in the Process of Manufacture-The Seedling Plant within the "Key"-Development of "Wings "-The Whirling Flight . . . I7-30

\section{CHAPTER III}

THE COMMON ARUM, OR CUCKOO-PINT (Arum maculatum)

Science reveals Economy in the Beauties of Nature-A Function for every Detail associated with the Organism-The Quaint Form of the Inflorescence-A Veritable Army of Midge-flies within-How the Arum starts Life-Development-Function of the Leaves-Meaning of the Quaint Floral Structure-The Midge-fly-Drunken Orgies within the Bloom-Buried in the Yellow Pollen DustTemperature inside the Bloom-Effects of the Cooler Air - The Reason of the Arum's Generosity-Arum not a Flower-Structural Details-The Purple Club-How the Midges are Entrapped-The Flowers Mature-Crossfertilisation-Intoxicating. Nectar-Showers of PollenHow the Pollen is Conveyed-Taking in the SignpostBrilliant Red Berries-A Self-contradictory TheoryThrushes' Development of a Power to Resist Poison-A Successful Plant more to Nature than a Foolish Animal .

\section{CHAPTER IV}

\section{CATKINS}

All Forest Trees bear Flowers-Plants that do not appear to produce Flowers-Fruit Necessarily a Product of the Flower-Hazel Catkins and Hedge-nuts-The Catkin a Pendent Spike of Male Flowers-Female Catkins-Bee and Catkins-Insects not desired-Little Shelves loaded with Pollen-Wind and Clouds of Pollen-Structure beautifully adapted for Action of the Wind-Pollen blown to Distant Towns-Size of Pollen Grains-Stigmas and Pollination-Their.Crimson Colour-Germination of the Pollen 


\section{CONTENTS}

Grain-Cross-pollination-Alder Catkins-Flowers of the

Ash and the Elm-The Perfect Unity that underlies all

Nature's Processes . . . . . . . 47-57

\section{CHAPTER V}

\section{SENSITIVE PLANTS}

The "Woolly Bear," or Larva of the Tiger-moth, and its Sense of Touch-The Hedgehog-Defensive Actions of Caterpillar and Hedgehog-Sense of Touch in Plants-The Sensitive Plant-Grazing Animals and Sensitive PlantsTempting Green Leaves instantly become Scrubby FareProtective Movements-A Caterpillar amongst the Leaves - How the Delicate Sensitiveness was First Acquired -The Wood-sorrel-Beginning of Sensitiveness in Leaves-A Useful Device-Copper-coloured FoliageOxalis sensitiva-Sensitive Characteristic Evolved from the Sleeping Habit-Explanation of the Shrinking Movement at the Approach and Touch of AnimalsSensitiveness in a Root-tip-The Aerial Roots of an Orchid-Sensitive Tendrils of Climbing Plants-Barberry and its Sensitive Stamens-Beetles within the FlowersHow Tightly the Stamens can Grip an Insect-The Purpose of the Device . . . . . . 58-72

\section{CHAPTER VI}

\section{THE COMMON PRIMROSE (Primula vulgaris)}

The Primrose Bank-Unfolding of the Leaves-Underground Rootstock-The Cowslip-Prinrose the most Advanced Member of its Genus-Bird's-eye Primrose-Its Protection against Heavy Dews-Flowers of Primrose and Cowslip in relation to Insects-'Two Types of FlowersWatching the Occasional Bee-Significance of the "Pineyed" and the "Thrum-eyed" Flowers-The Proboscis of the Bee-Pollination Efficiently Performed by InsectsScattering of the Seeds-Winter-The Seedlings . . 73-83 


\section{CONTENTS}

\section{CHAPTER VII}

\section{LABURNUM (Cytisus laburnum), BROOM (Sarothamnus scobarius), AND GORSE (Ulex europreus)}

Laburnum and Red Hawthorn-The Broom's Blaze of Golden PAGES

Yellow-Leaves of Laburnum, Broom, and GorseLeaves Characteristic of the Pea-flower Family and their Modifications-Their Arrangement in the LaburnumChange in Position of Flowering Stem-The Foliage of the Broom-Starving off its Enemies-Broom FlowersDivergence from the Ancestral Type-The Gorse and its Thorny Foliage-Young Shoots used as Fodder-Existing Proof that the Gorse once had Trefoil Leaves-The Young Plant Records in miniature the whole Evolution of its Species-Perfect Bayonet Protection-Branches carry on Leaf-functions-The Unceasing Warfare between Plants and Animals . . . . . . . . 84-96

\section{CHAPTER VIII}

\section{SOME STRANGE GREENHOUSE PLANTS}

Variety in Plant Forms-Species that Puzzle our Understanding-Cactus Family- "Vegetable Camels"-Dangers; from Animal Attacks-Unassailable Protection-Offshoots Distributed by Enemies-The Caladium-Leaves several Feet in Length--Large Leaves and Open Situations-Pitcherplants-Entrapped Insects-An Original Orchid-A Topsyturvy Attitude-Throwing off Water-Torrential Rains and Long Periods of Drought-Only a Moist Atmosphere needed

\section{CHAPTER IX}

\section{THE COLTSFOOT (Tussilago Farfara)}

The Farmer is bent on Warfare-How the Coltsfoot made the First Move-A Successful and Enterprising WeedHow it came to Possess such Power-Its Credentials$\mathrm{xii}$ 


\section{CONTENTS}

Overcoming the Soil Difficulties-A Peep at the UnderPAGES ground Stem-Its Methods of Meeting the Farmer's Attacks-Scaly Flowering Stems-The Flower-headsOvary Losing Power of Maturing its Seed-Cross-fertilisation-Guarding the Pollen-Fluffy Heads of Seeds in March and April-A Modified Calyx-On the Newlymade Railway Cutting-The Matter of Leaves-The Building Process-Monopolising Sunlight-Function of the Woolly Hairs-The Farmer Again-Defiance . . 106-II7

\section{CHAPTER $\mathrm{X}$ \\ THE CATKINS OF THE WILLOW \\ (Salix Caprea)}

The Sallow or "Palm" of the Country People-Willow-blooms and Easter Religious Ceremonies-British WillowsGolden or Yellow "Palm"-The Catkins-A Male Flower-Silver "Palm"-A Female Flower-Male and Female Catkins growing apart on Distinct Trees-Insects and the Catkins-Wind- and Insect-fertilisation-A New Nectary-The Lost Perianth-Female Flowers producing Nectar-Origin of the Unisexual Flowers-Wind-fertilisation now Abandoned . . . . . . . . 118-126

\section{CHAPTER XI \\ THE WILD ORCHID (Orchis maculata)}

My Orchid Garden-The Blooms-Nothing more Extraordinary in the Plant World-Roots and Tubers-The Plant Exploits New Ground-Striking and Mysterious LeavesTheir Curious Brown Markings an Insoluble Problem-A Suggestion-The Startled Reptile-Arrangement of the Leaves-How Grazing Animals view the Plants-Necessity of Protection for Leaves-Spotless Leaves-Plants that Resemble Animals-Complex Specialisation of Floral Structures-An Orchid but a Modification of some Type of Lily-Structural Details-The Visiting Insect and the xiii 


\section{CONTENTS}

Stamen-Changing of Position of the Pollen Clubs-The

Stigmas - No Honey in the Spur-Darwin's suggestion -Adhesive Nature of the Pollen Masses-The Twisted Ovary $127-142$

\section{CHAPTER XII}

THE QUAKE-GRASS (Briza media)

The Quake-Grass a Modified Member of the Lily FamilyGrasses the most Perfect Type of Wind-fertilised PlantsUtility of the Inflorescence-The Spikelets-Stigmas and Stamens-A Perfect Arrangement for Pollen DispersalDegenerate Lilies-Details of Flower-Trinary Arrangements almost Lost-Progress and Degeneracy-Grasses and Orchids

\section{CHAPTER XIII \\ THE WHITE OR DUTCH CLOVER \\ (Trifolium repens)}

Clovers, Descendants of the Pea-flower Family-Inflorescence of the Family Progenitor-Grouping of the Flowers-The Course of Evolution-A Sure Sign of Advancement-Colour-A Large Supply of Honey with Little WorkPollination of the Stigmas-Assisting (unconsciously) its Insect Guests-Seed Pods-Creeping Stems -Each Species possesses Characteristic Devices-Subterranean CloverA Modified Calyx and its Function-Sowing its SeedsThe most Specialised Member of the Pea-flower Family

$150-159$

\section{CHAPTER XIV}

\section{THE STONECROPS (Sedum)}

The Orpine, or Livelong-Insect Visitors-Wall-Pepper-Its Popular Name-All Species are Succulent-An Experiment with the Mock Orange and the Orpine-The "Cactus" of British Plants-No Protective Devices xiv 


\section{CONTENTS}

-An Uneventful Career-Simple Leaves-Primitive Sim-

plicity Revealed by Flowers-Monocotyledons and Dicotyledons-Primitive Form retained owing to Lack of Competition . . . . . . . . . 160-165

\section{CHAPTER XV}

\section{THE DAFFODIL (Narcissus Pseudo-narcissus)}

Threefold Flowers-Daffodils and Lilies-Superior or Inferior Ovary-Advanced Groups of Lilies-Complex Lily Types -Bilateral Flowers-The Crown, or Entrance TubeStigma and the Bee-Origin of the Crown-The Pink Family-Nature and Successful Devices . . . I66-I7I

\section{CHAPTER XVI \\ BUTTERCUP EVOLUTION}

Buttercups and English Landscape-Pedigree ButtercupsBulbous Buttercup-Meadow Buttercup-Difference in Height-Variety in Species-Water Buttercup-Adaptation to Aquatic Surroundings-Aquatic and Aerial Leaves -A Unique Water Plant-Colour of Petals-HairsTypical Buttercup-Coloured Calyx-Nectaries of Hellebore and Globe-flower-Anemone and Clematis-Honeyless Flowers Rich in Pollen-Marsh Marigold-Honey amongst the Carpels-Lesser Meadow Rue and Windfertilisation-Aristocrats of the Family-The ColumbineThe Larkspurs-Fertilisation-Monkshood-The Specialised Nectaries-Insects' Unconscious Agency-Complex Forms

\section{CHAPTER XVII}

\section{SOME FLORAL ADVERTISEMENTS}

The Foxglove at Home-The Difficulty Overcome-Competition in the Plant World-A Huge Advertisement designed exclusively for Humble-bees-Honeysuckle-Hawk- 


\section{CONTENTS}

moth Visitors-Attracting Power of Scent-General

PAGES Advertisers-White Water Lily-Small Flowers Massed together for Show-The Wild Angelica-Unsymmetrical Flowers-Guelder Rose-Neuter Blossoms-Cornflower 186-192

\section{CHAPTER XVIII}

\section{FERNS (Filices)}

Flowerless Plants-"Spore-plants" and "Seed-plants"Fructification of Ferns-A Common Error-The Sporecase-Spores and Atmosphere-Spores do not Produce Ferns-Germination of a Spore-The Prothallus-Antheridia and Archegonia-Birth of the Fern Plant-Flowerless Plants in the Carboniferous Age-Ferns once a Great Race-Advent of Pollen- and Nectar-seeking Insects . r93-rg8 


\section{LIST OF PLATES}

GUElder Rose (Viburmum Opulus) . . . PLATE

1. The Wild Camomile at home . . Facing page 2

2. Camomile flower-head-Tiny tubular florets from the central mass of the Camomile Daisy

3. Foxglove and Ox-eye Daisy-Part of a rayFrontispiece foret showing the one-sided development of the tube to produce the petal-like part .

4. Branch of Wild Camomile photographed at mid.day

5. The same branch photographed at 6 p.m. .

6 . Showing the development of the young seedling from the Sycamore "key" . . .

7. Unfolding of the nurse-leaves-The first pair of true leaves appear. . . . .

8. The nurse-leaves then shrivel up-A flower bud opening . • . . . . " 23

9. Young branches developing from the buds .

I0. The pendent stalk of flowers appears-Stigmabearing flowers whose stamens develop later or not at all .

II. The flowers attract swarms of flies of many species-Wild bee feeding on the nectar of the flowers . . . . . .

12. Stigma after having been visited by a fly, showing the pollen grains upon it-Showing how the flowers slowly change into Sycamore "keys"

13. Hairs from body of a bee, showing pollen grains entangled .

I4. The completed work at the end of August

I5. Common Arum

I6. The first stages - The second leaf 


\section{LIST OF PLATES}

PLATE

I7. A third leaf and the curious central object-

The central object has become important Facing page 35

I8. The fully-developed Arum

I9. Midge-fly-Chamber where the midge-flies are entrapped . $\quad$ • $\quad$ • $\quad$ • $\quad$ " 37

20. Showing the minute pollen grains adhering to the wings-The decline of the inflorescence

2I. Bursting from it is a cluster of plump green berries-The scarlet berries .

22. Pollen grains from Hazel catkins (immensely

23. Male and female catkins of the Hazel or Nut

23. Male and female catkins of the Hazel or Nut
Tree-Female catkin magnified to show pollen grains on its stigmas

24. The catkins appear in the autumn together with the nuts-Pollen tubes of Evening Primrose penetrating the stigma

25. Alder catkins-Flowers of the Ash Tree . " 54

26. Flower of the Ash-Elm flowers . • • " 55

27. Leafy, winged seeds of the Elm-Winged seeds or "keys" of the Ash . . .

28. The Sensitive Plant when circumstances are favourable; but if you breathe upon it-

29. It immediately closes its leaflets__ •

30. Lets fall its leaf stalks, and a second later-

3I. Presents this appearance - ${ }^{-} \cdot{ }^{\circ}$

32. Species of Oxalis with leaves in sleeping attitude . $. ~ \cdot . \cdot$

33. Tip of the young root of Barley showing its sensitive root-cap. . . . .

34. An Orchid whose sensitive roots leave the pot and feed upon the atmosphere . . .

35. Sensitive tendrils of the Bryony plant seeking for a friendly grip-Barberry flowers with sensitive stamens. In next Fig. they are seen to have- . . . . . . losed down on the ovary or central part of the flower-Showing how tightly the stamens can grip an insect. Two stamens are holding a large pin 


\section{LIST OF PLATES}

PLATE

37. Cowslip, a relative of the Primrose-Primroses

and-green-veined white butterfly .

Facing page 74

38. The flowers present a bold show that is conspicuous even at night

39. The "pin-eyed" and "thrum-eyed" forms of flower

78

40. Magnified view of the end of the bee's proboscis .

4I. The offspring growing up around their parents

42. Primroses in the coppice . . . . .

43. Laburnum

44. Broom

45. Gorse seedlings developing thorns from their primary trefoil leaves . . . . . . 93

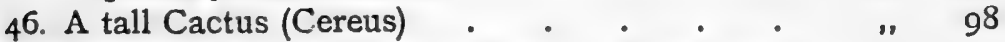

47. A short Cactus (Mammillaria) - The plant two months later

48. Caladium: a South American relation of the Common Arum .

49. Pitcher-plant (Nepenthes)
50. An Orchid (Cattleya citrina) that grows upside down

51. The Coltsfoot develops its stem underground in a horizontal position

52. The broad angular leaves of the Coltsfoot .

53. The leaves of the Coltsfoot thrust their way amongst the grasses and other plants into the sunlight

54. Fully developed and half developed catkins of the Golden "Palm"

55. Fully developed and half developed catkins of the Silver "Palm"

92

93

9 


\section{LIST OF PLATES}

PLATE

6o. The bristle represents the tongue of an insect being inserted in the tube of the nectaryThe bristle being withdrawn. Observe the two tiny clubs now upon it . . . Facing page 138

6r. Magnified view of the pollen clubs . . . . " 139

62. Quake-grass with unopened spikelets . . " I44

63. Quake-grass with opened spikelets and stamens protruding . . . .

64. Flower from a spikelet of Quake-grass showing the two feathery stigmas, three stamens, and covering scales magnified . . . " I46

65. White or Dutch Clover . . . . . . I50

66. Development of a flower-head of Clover as the florets are fertilised by the visiting bees . " I $_{5} \mathbf{I}$

67. The Orpine, or Livelong . . . . . . I60

68. Wall-Pepper-Wall-Pepper growing on a roof $\quad$ " 162

69. Branches of Orpine and Mock Orange exposed to daylight and without water-Half an hour later the Mock Orange has half collapsed .

70. Six hours later, the Orpine is still fresh-The Orpine beginning to flag twenty-six hours later

7r. Daffodils .

72. Meadow and Bulbous Buttercups

73. Roots of the Meadow and Bulbous Buttercups

74. Water Buttercup with aquatic and aerial leaves .

75. Clematis .

76. Columbine-leaved Meadow Rue . . . $\quad$, 179

77. Columbine-Larkspur . : . . . , 182

78. Monkshood flowers and their nectaries . . . $\quad 183$

79. Foxgloves . . . . . . , 186

8o. Honeysuckle or Woodbine . . . . " $\quad 187$

81. Wild Angelica . . . . . . " 188

82. Cornflowers . . . . . . . Igo

83. White Water Lily . . . . . . . I9I

84. Fructification of Pteris, Davallia, and Polystichum

I92

85. Germinating Ferns - Hart's-tongue Ferns growing from between bricks of a wall . " 193

86. The Prothallus produced from the Fern Spore ." I94 


\section{LIFE HISTORIES \\ OF FAMILIAR PLANTS}

\section{CHAPTER I}

THE WILD CAMOMILE (Matricaria Chamomilla):

A WEED OF EMINENCE

THE wild camomile is a most accommodating plant. It only needs the slightest introduction to make itself quite comfortably "at home." I well remember its advent in a field at the top of the lane. Some seasons back the farmer cultivated this field with swedes, and it was then that the camomile got its chance. How the first seeds came there I am not prepared to say; most probably they came with the seeds of the root crop, for there are no other fields in the near vicinity that, to my knowledge, offer friendly shelter to this weed. Or, it may be, a bird had been feeding on the seeds at some distant spot and flew down into this field one wet day, bringing a single seed adhering with a little mud to one of its feet. That would be quite sufficient, provided the seed had a little open space in which to make a start; the camomile would do all the rest!

B 


\section{LIFE HISTORIES OF FAMILIAR PLANTS}

At first the farmer was lenient; he found the weeds growing apace, and bundled them outside the gate into the lane on the rubbish heap. Now, if there is one spot on the earth that the camomile loves, it is a rubbish heap. There it will hold up its blossoms to the sunlight from early June until the end of October, or even November. So presently that rubbish heap exhibited to passers-by quite a glorious display of white and yellow blooms, and, although school children treated them unmercifully, the plants flourished, and never failed to show an ample store of blossoms.

The following year, for some reason, the farmer neglected his field entirely, and the camomile, spying out the land from the top of the rubbish heap, was not slow to recognise its opportunity. That, at all events, is my conclusion. I have endeavoured to show you a small corner of it on Plate I.

In the sunlight the field presented a veritable sea of daisy blooms. There they stood, thousands of plants, with branches two or three feet in height, and all more or less covered with blossoms ; they held the field, no other plant growing amongst them. It is true that some straggling and sickly-looking groundsel, and still more sicklylooking dock, may have been found low down, but their days were numbered. This, indeed, was a plain case of "survival of the fittest"; for this wild camomile weed comes of a very dominant family of plants, a family that stands at the head 


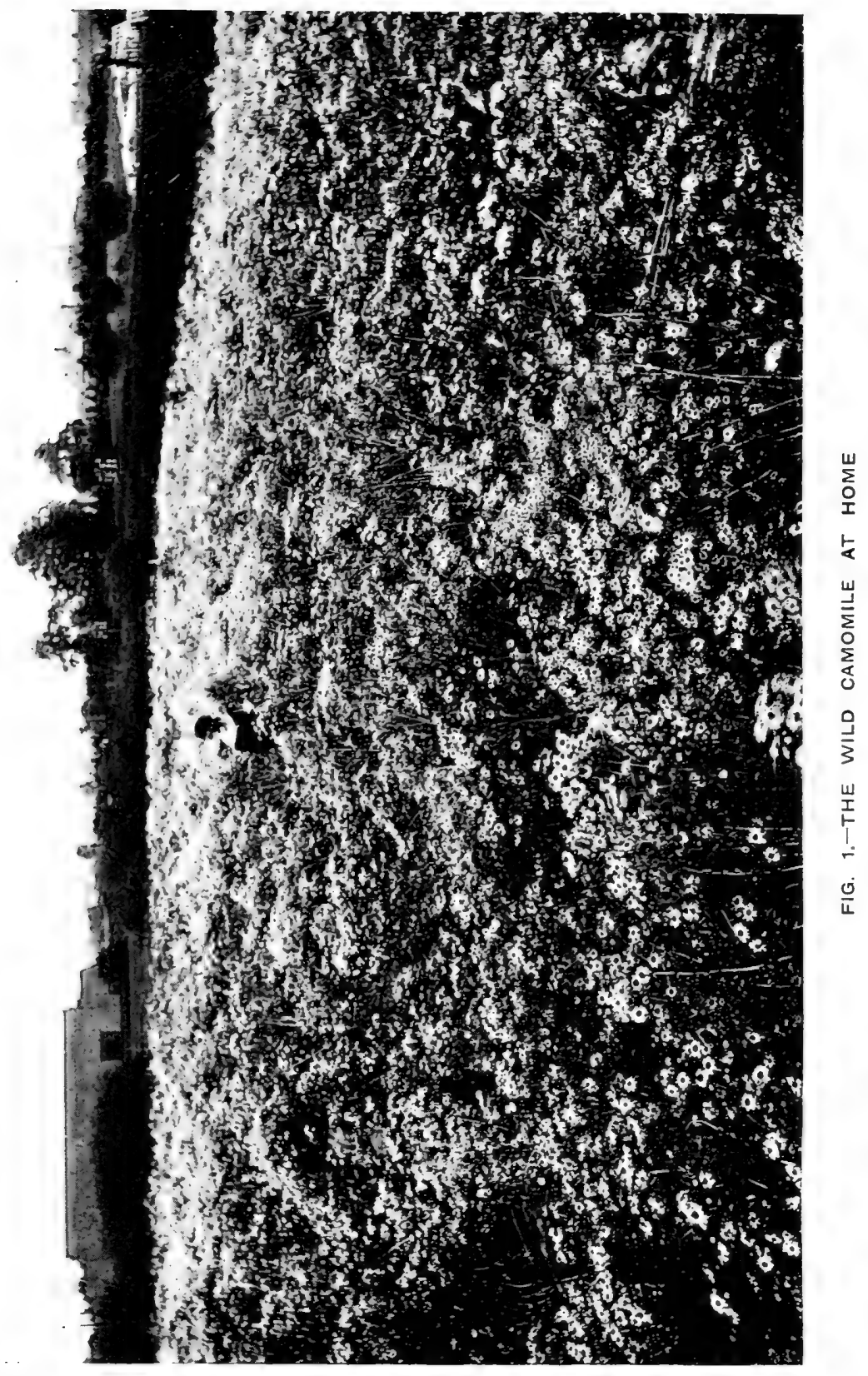





\section{THE WILD CAMOMILE}

of the vegetable kingdom, just as man stands at the head of the animal world.

- But, it may be said, there are oak, elm, and pine trees; surely these must come before such simple and insignificant weeds of the field ? Then I may make reply that there are elephants, whales, and other huge living animals, to say nothing of the greater monsters whose fossil remains record their earlier existence ; but, nevertheless, in relative development man is far superior to all these, and much more highly evolved. Indeed, for such comparisons, size can be no criterion whatever. This is well illustrated by the fact that the highest amongst British animals is the bat; these little, weird, nocturnal animals rank next to man in the mammalia of the British Isles.

In view, then, of the fact that the wild camomile has so well established itself that it is now one of the most successful plants in the vegetable kingdom, it should prove interesting to consider a few details of its history, especially as these details throw considerable light on the reasons for its success in life, and show how it came to hold such eminence in rank. However, before going farther, I had better say that there are other plants very nearly related, such as the familiar ox-eye daisy (Fig. 4, Plate 3), the yellow corn-marigold, the feverfew chrysanthemum, and similar plants (not forgetting the common field daisy), which are just as successful in life; and what I state here concerning the camomile may be applied (allowing for insignificant differences of detail) in a general way 


\section{LIFE HISTORIES OF FAMILIAR PLANTS}

to all such plants-that is, to plants that bear daisy-like blossoms.

Doubtless, the secret of the daisy tribe's success is the daisy-like form of its inflorescence. I say "inflorescence" and not "flowers" advisedly, because I purpose now to show that a daisy is not a flower. It is, however, a most extraordinary simulation of one. You will understand better what I mean if you will take the trouble to pull to pieces the next buttercup, dog-rose, or bramble flower you happen to meet with. Outside the coloured petals of these flowers you will find (I) some protective green leaf-like sepals; (2) inside the petals numerous stalked stamens which produce the fertilising dust known as pollen, and (3) a central part occupied with the carpels, or ovaries, in which the seeds are matured after the fertilising pollen from the stamens has reached them.

Now dissect in a similar manner a camomile, or some other daisy-like bloom, and you will soon discover that things are very differently arranged there. The green "sepals" of these "flowers" are numerous and closely packed around the base of what seem like petals (what they are we shall learn later), but then comes a rounded central mass of tiny objects which we see are quite unlike the stamens and ovaries of the buttercup or bramble flower. Hence, although the camomile daisy appears to resemble other flowers, if we try to compare it with, say, a buttercup, or, in fact, any ordinary single flower, 


\section{THE WILD CAMOMILE}

we find a very great difference in structure; and no wonder, for if we had eyes that would magnify a few diameters, we should then realise that in each daisy there are really several hundreds of tiny flowers in very orderly arrangement, and nearly all of them possessing the various organs found in the bramble or buttercup flower.

Now, the way out of the difficulty of understanding the camomile is to use a magnifying lens, for the head of florets measures little more than half an inch across even when fully expanded, and in this space there are hundreds of flowers each as perfect as a buttercup, or even more so; but on this point more later. Lest you may think it too great a trouble to separate the tiny flowers that make up the daisy bloom, I will dissect a blossom and photograph it through my magnifying lens, and so show by direct photograph the actual thing.

If, however, you are feeling any regret that you are unable yourself to examine the actual flowers because you are not accustomed to dissect such small things and to use a magnifying lens, let me advise you to go into your garden and cut a large daisy-one about a foot in diameter. Pray do not look so startled. You, doubtless, grow sunflowers, or, at least, know where they are grown, and sunflowers are only very large daisies. In these large forms, then, the numerous flowers of each head are big enough for you to examine them with the unaided eye.

In Fig. 2 (Plate 2) is shown my camomile 


\section{LIFE HISTORIES OF FAMILIAR PLANTS}

bloom sliced through and slightly magnified, and it will be noticed that in the centre is a hollow conical space, and that from the walls enclosing this space spring numerous little short tubes, all very closely and systematically packed together. I now select four of these little tubes, one from very near the top of the rounded mass; two others from successively lower levels, and finally one from the lowest layer; and in Fig. 3 (Plate 2) you will see these further magnified and arranged in their relative positions.

Now I may say that each of these little central tubes represents a single flower, or floret, of the camomile; each is as truly a flower as the rose is the flower of a rose tree, as truly a flower as that produced by the buttercup, bramble, or dog-rose we have previously spoken of ; in fact, each floret constitutes an altogether higher and more advanced type of flower than either of the larger flowers mentioned above, as I will endeavour to show later.

Darwin has conclusively proved that flowers when cross-fertilised (that is, impregnated by pollen from the stamens of other flowers of their species), produce better seed, and in greater quantity than when self-fertilised (i.e., impregnated with their own pollen), and it follows that those plants whose structures are best adapted to effect cross-pollination necessarily make greater progress and become better fitted to survive in the struggle for existence.

Now, primitive flowers, before the advent of 


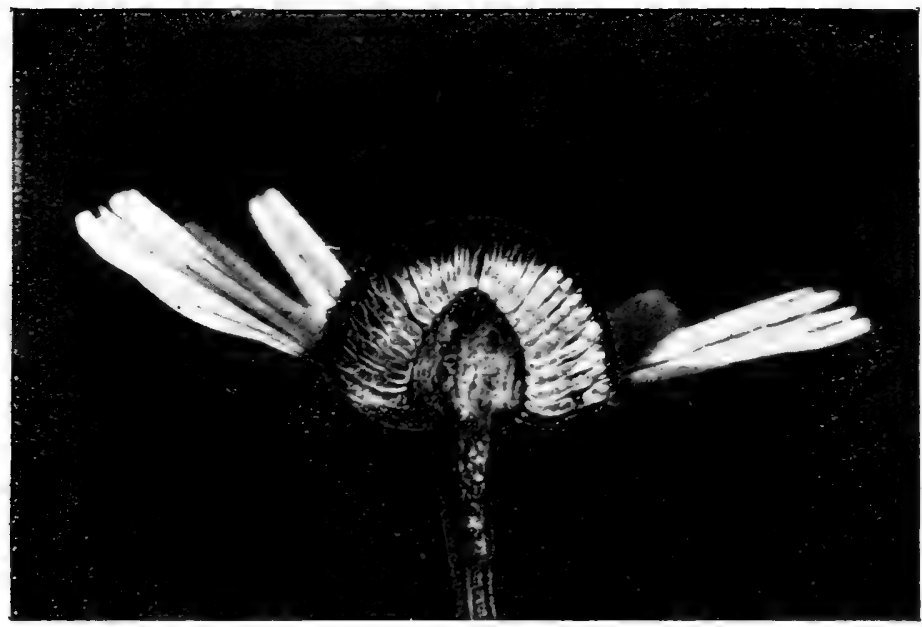

FIG. 2.-CAMOMILE FLOWER-HEAD (sliced through and magnified)

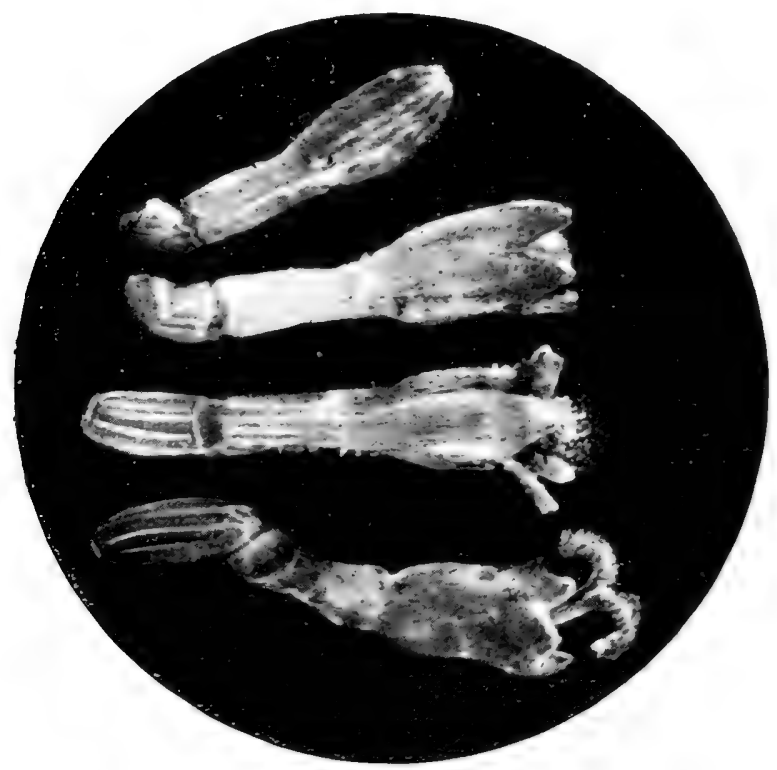

FiG, 3.-TINY TUBULAR FLORETS FROM THE CENTRAL MASS OF THE CAMOMILE DAISY (more highly magnified) 


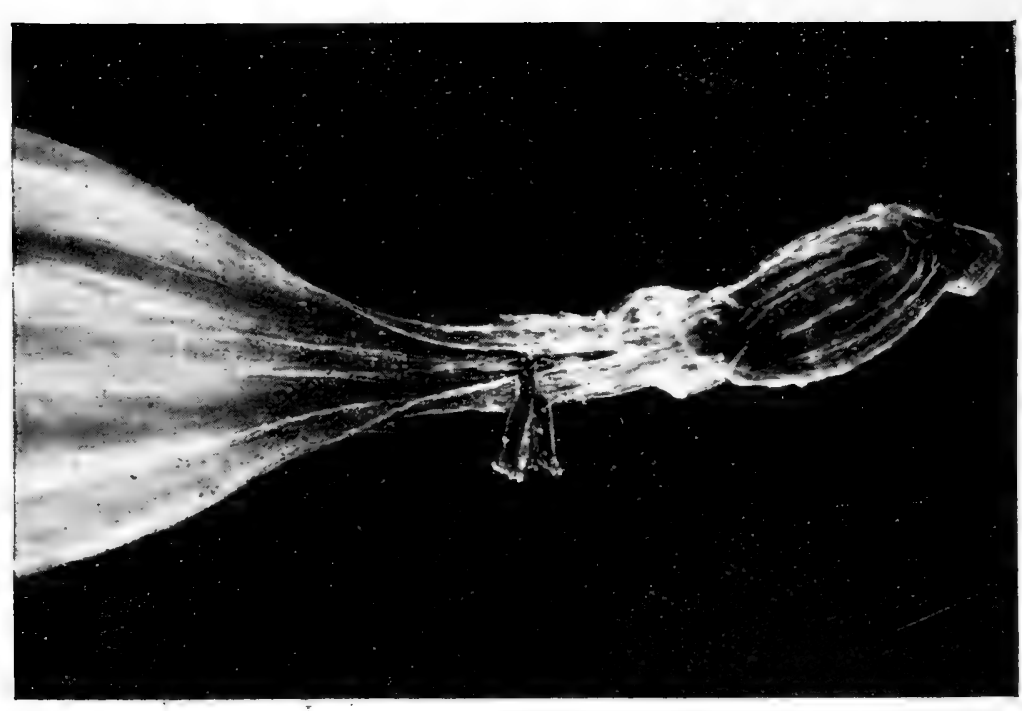

난요 I 路的。

了

인은 का 乩岩岩㟧 岁员的 和岁

山

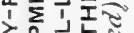

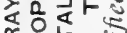
w山 $\sum_{0}$ : 《正山礼 니도 ○ เ俞㟧品

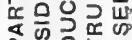
的。 เo z选 은

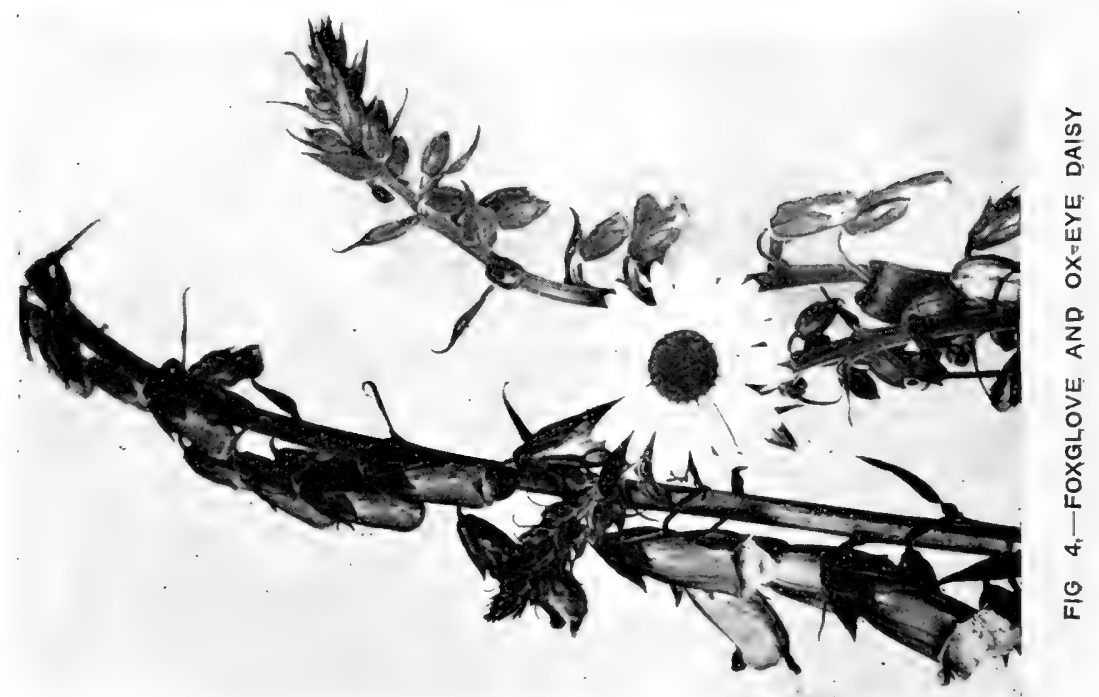




\section{THE WILD CAMOMILE}

insects, or before insects had become so numerous or so varied as in the present day, were often cross-pollinated by the wind blowing the pollen from the stamens of neighbouring flowers to the stigmas, or sensitive surfaces, of the ovaries. As will be shown in a future chapter, many plants still carry on this primitive method of pollination by the wind, and such plants have acquired the habit of producing vast quantities of pollen as a means of insuring the stigma being reached by some of it.

And, as time went on, insects discovered that this pollen so abundantly produced was a very nutritious substance, and consequently developed the habit of eating it ; and in travelling from plant to plant in search of it, they often cross-pollinated flowers by conveying pollen (which adhered to their hairy legs and bodies) from flowers they had previously visited. This considerably benefited the plants so visited, as it insured cross-fertilisation, and although quantities of pollen were lost through being consumed by the insects, yet the net gain to the plant was considerable, as a little pollen conveyed by insects pollinated more stigmas than when the wind was the sole agent of distribution; at the same time the work was done more surely.

Consequently, in the course of time a smaller quantity of pollen would be provided by such plants. Then insects would gradually cease visiting flowers where they were not well fed, and thereupon a new attraction appeared, one less costly 


\section{LIFE HISTORIES OF FAMILIAR PLANTS}

to produce than pollen, viz., sweet nectar, and this sweet fluid pleased insects even more than pollen. It may be asked: How could plants suddenly produce nectar? The answer to that is that there are many plants which secrete drops of nectar about their leaves as a means of keeping ants and such harmful insects away from their flowers, and there is no reason why nectar should not appear around the floral parts for the purpose of attracting other insects which would be welcome and useful guests.

I may seem to be making some digression from the subject of those four little tubes that I dissected from my camomile daisy, but I want the reader fully to understand the elements of the subject so that he may appreciate how marvellously the structure of the daisy type of inflorescence has been worked out for the good of the plant, and how intricate are Nature's schemes even down to the microscopic details of a camomile flower.

Now, when a person has produced a desirable commodity, from a business point of view, the next thing is to put it on the market and advertise it well, so as to make it known. Man was by no means a pioneer in this kind of enterprise. Plants had been advertising extensively ages before man came on the earth, and competition was very keen amongst them when he made his advent. Those plants which advertised best, or which put out the most attractive posters, so to speak, naturally did the largest business. 


\section{THE WILD CAMOMILE}

Or, I will put it in another way; the flowers of those plants which happened to develop coloured petals about their floral parts (i.e., the ovary and stamens) caught the eyes of passing insects first. These petals were to the insects the equivalent of the signboard of the inn to the thirsty traveller; the insect read from them "Stop here for prime sweet nectar." The coloured petals, then, were advertisements pure and simple; the plant provided nectar for insects and in return asked of the insect that in seeking the nectar it should rub against its stamens, and so (unknowingly) carry its pollen to the stigmas of sister blooms. Of course, the insect at the same time was bringing pollen from some brother flower to this flower for its own stigma.

These petals, be it noted, were comparatively easy to produce by sacrificing a few outer stamens ; these stalked bodies readily flatten out and become petals, as you may witness for yourself in any double flower that your garden produces. The gardener, too, is well aware of this, and by cultivation readily produces double roses and other flowers, for it will be remembered that the wild rose has only five petals but numerous stamens, while the cultivated garden rose has numerous petals and few or no stamens.

The bright petals of the flowers of the buttercup, rose, or bramble are, then, simply devices for attracting insects. The essential parts required for reproduction are stamens and ovary. But, as I have previously stated, the little florets of the 


\section{IIFE HISTORIES OF FAMILIAR PLANTS}

wild camomile are more evolved and belong to a higher type of flower than the familiar buttercup, rose, or bramble, and now I will explain why.

As time went on and the coloured petals succeeded so well in drawing the attention of insects, it happened that the nectar and colours of certain plants proved more attractive to certain types of insects than to others; so they gradually adapted themselves to these particular insect visitors. If you will notice the next stalk of foxglove flowers (Fig. 4, Plate 3 ) that you meet with, it will make my point quite clear. These flowers, it will be seen, have joined their petals together to form a tube that fits almost exactly the humblebee that visits them. A foxglove, then, is a higher type of flower than our bramble, buttercup, or rose, because it has specialised by uniting its petals together to form a tube specially adapted to a particular form of insect, an adaptation which makes it practically certain of pollination when the bee enters, whereas in open flowers, as buttercups and wild roses, pollination is not so certain.

Also, notice that the flowers of the foxglove are arranged on a special central stalk (not mixed up with leaves), and that they open from the bottom upwards, the youngest being at the top (Fig. 4, Plate 3). Of course, it is plain that the bee can only visit one flower on the stalk at a time; but now let us suppose that a plant, with a stalk of flowers something on the lines of the foxglove, should slowly shorten its stalk and evolve such an arrangement of its flowers that they 


\section{THE WILD CAMOMILE}

became crowded all together on a more or less flat surface, so that the bee could, as it were, tumble out of one into the next immediately, without seeking for it round and up or down the stem. This, of course, would result in a great saving of time in the day's work of the busy bee, and the bee would thus be able to visit many more flowers. Then if the same plant narrowed down its tubular flowers into smaller tubes, so that the bee would only have to thrust in its proboscis or tongue to reach the nectar, instead of entering the flowers, a still further advantage would be gained in the same direction.

It is easily seen that our camomile daisy has done all these things. If you could take hold of the centre florets of a daisy blossom, at the point where the youngest flowers are found, and pull it upwards, spiral-fashion, until it became straightened out, just as you might the centre of a watchspring, you would then have in miniature a stalk with numerous florets arranged about it with the youngest at the top, very like the foxglove. Or, conversely, if you could press in from the top, spiral-fashion, the stalk of the foxglove so that the youngest flowers were left in the centre and the oldest outside, you would have produced a kind of large daisy. I do not mean, of course, that daisies have originated from foxgloves, but simply desire to show how the shortening of a stalk of bell- or tube-shaped flowers could produce a daisy-like inflorescence.

Now, if we look at Fig. 2 (Plate 2), we see the 


\section{LIFE HISTORIES OF FAMILIAR PLANTS}

rounded central mass arranged about the wall of a hollow conical space, and this walled space is really the equivalent of the foxglove's elongated stalk. Also we notice in Fig. 3 on the same plate that the highest tube, or floret, which comes from the top of the central mass is unopened, because it is one of the youngest flowers. The second one is seen to be opening its petals, and the third is opened and pouring from its mouth a mass of pollen, pushed from the united ring of stamens within by the stigma as it makes its way through. The stigma, however, does not open its receptive surface while working through lest it should be pollinated with its own pollen. In the lowest floret the stigma has appeared and opened its receptive surface.

If you watch a bee when it visits a daisy inflorescence, you will see that it starts on the lowest and widest-opened florets, and then works round thrusting its proboscis in each tube as it goes in search of the nectar. Having just come from a neighbouring blossom, with its body and legs well dusted with pollen, the projecting and sticky stigmas, being outermost on these florets, are practically certain to receive some of this pollen. The bee eventually reaches the higher tiers of florets where the pollen has appeared, but from which the stigmas have yet to protrude, and after it has ransacked these for their nectar it is again well dusted with pollen. It leaves the younger and unopened florets for some other day, and so departs loaded with fertilising pollen for the 


\section{THE WILD CAMOMILE}

stigmas of the lowest florets of the next daisy bloom it visits ; for the bee generally keeps to one kind of nectar on each of its journeys, although occasionally it may suddenly find attractions elsewhere. In such cases, however, the pollen conveyed usually has no effect unless the species visited is nearly related, when the seeds may produce a hybrid form.

I think the meaning of the central yellow mass of the camomile daisy will now be understood and if such daisy blooms be looked at closely the successive stages of unopened, opening, and opened flowers may be seen by the observer. This, too, explains why daisies are so lasting as cut "flowers" - the blossom lasts while the numerous florets have time to open and develop.

There still remain, however, the white outer florets. What of these? Well, when the daisies adopted this method of dwarfing and crowding their flowers together, although they attained the desired end of rapid pollination by insect agency, yet they necessarily did away with large showy petals, which was a somewhat serious loss, for this convenient arrangement certainly needed attraction for the insects for which it was designed. The problem was solved, though, by specialising the outermost row of florets. That specialisation consisted in suppressing their stamens entirely, leaving them with an ovary only, and then the energy which would have been required for building their stamens and pollen was directed into producing a one-sided development of their 


\section{LIFE HISTORIES OF FAMILIAR PLANTS}

tubes; so that we get, apparently, all round the yellow central florets strap-shaped white petals; but in reality these outer florets are just like the inner ones, except that the tubes are abnormally developed on one side, that their stamens are absent, and that they are white, whereas the central florets are yellow, Fig. 5 (Plate 3).

Thus the daisies have mimicked the appearance of a single flower, owing probably to the fact that insects had so thoroughly learned to distinguish that style of floral form that it had become indispensable. Insects, however, and especially bees, have learnt to distinguish between single flowers and the composite class, and they patronise the latter much more freely, for the simple reason that they find them so much more profitable; that is to say, they get a bigger supply of nectar and pollen in a shorter time with less trouble. This patronage results in further establishing the daisy tribe, and therefore to-day it is the most extensive family of flowering plants in the world.

The wild camomile presents many other interesting aspects, such as its method of dividing up its foliage into the finest segments, so that, no matter how crowded it may be amongst grasses and such like leaves, it can edge its way between and get some of the all-important sunlight. Such details all point to the keen struggle it has had to attain the rank and power that it now possesses. However, I will conclude this brief monograph by pointing out a somewhat striking feature that I particularly noticed while 


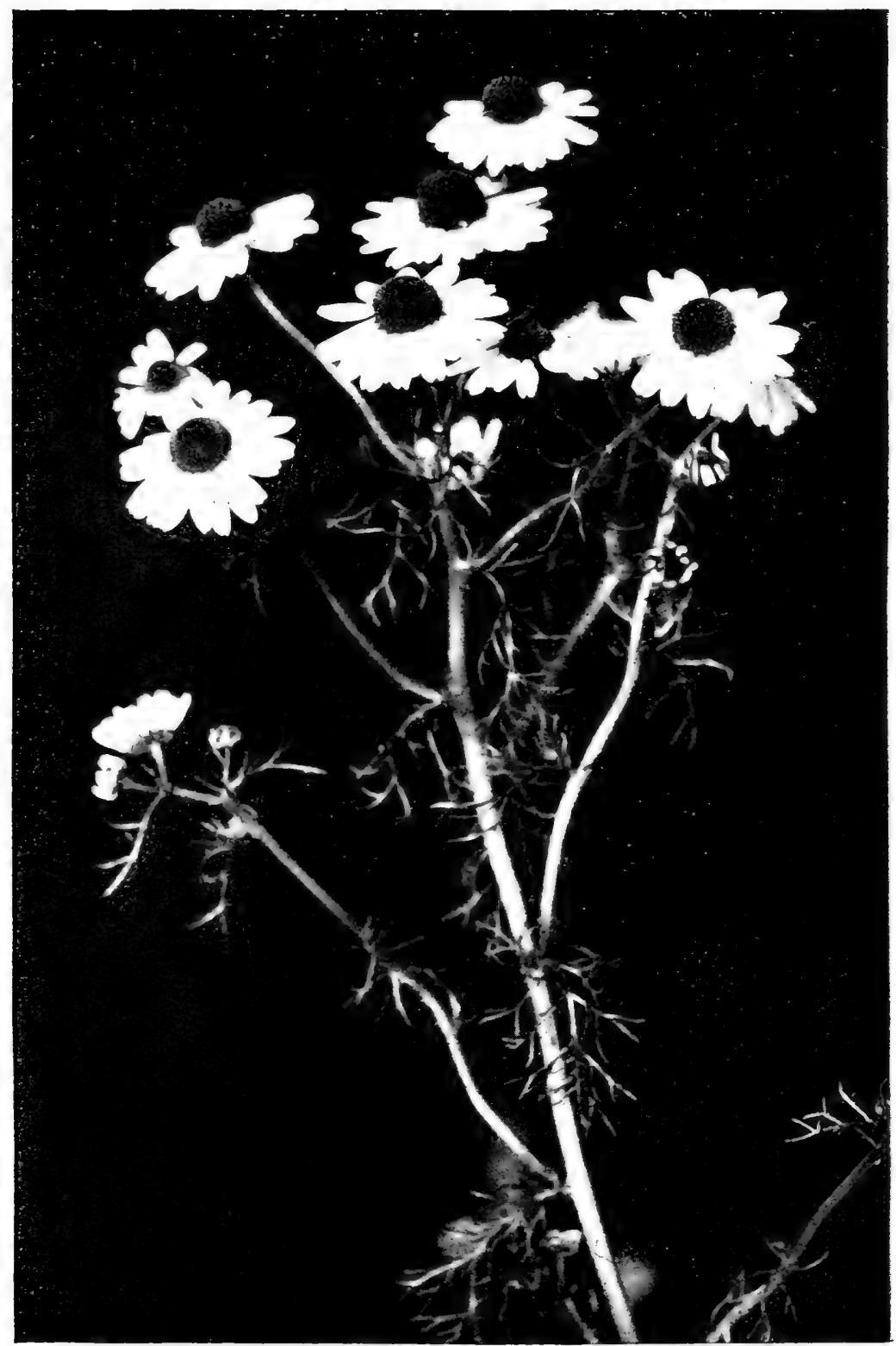

FIG. 6.-BRANCH OF WILD CAMOMILE PHOTOGRAPHED AT MID-DAY 
PLATE 5

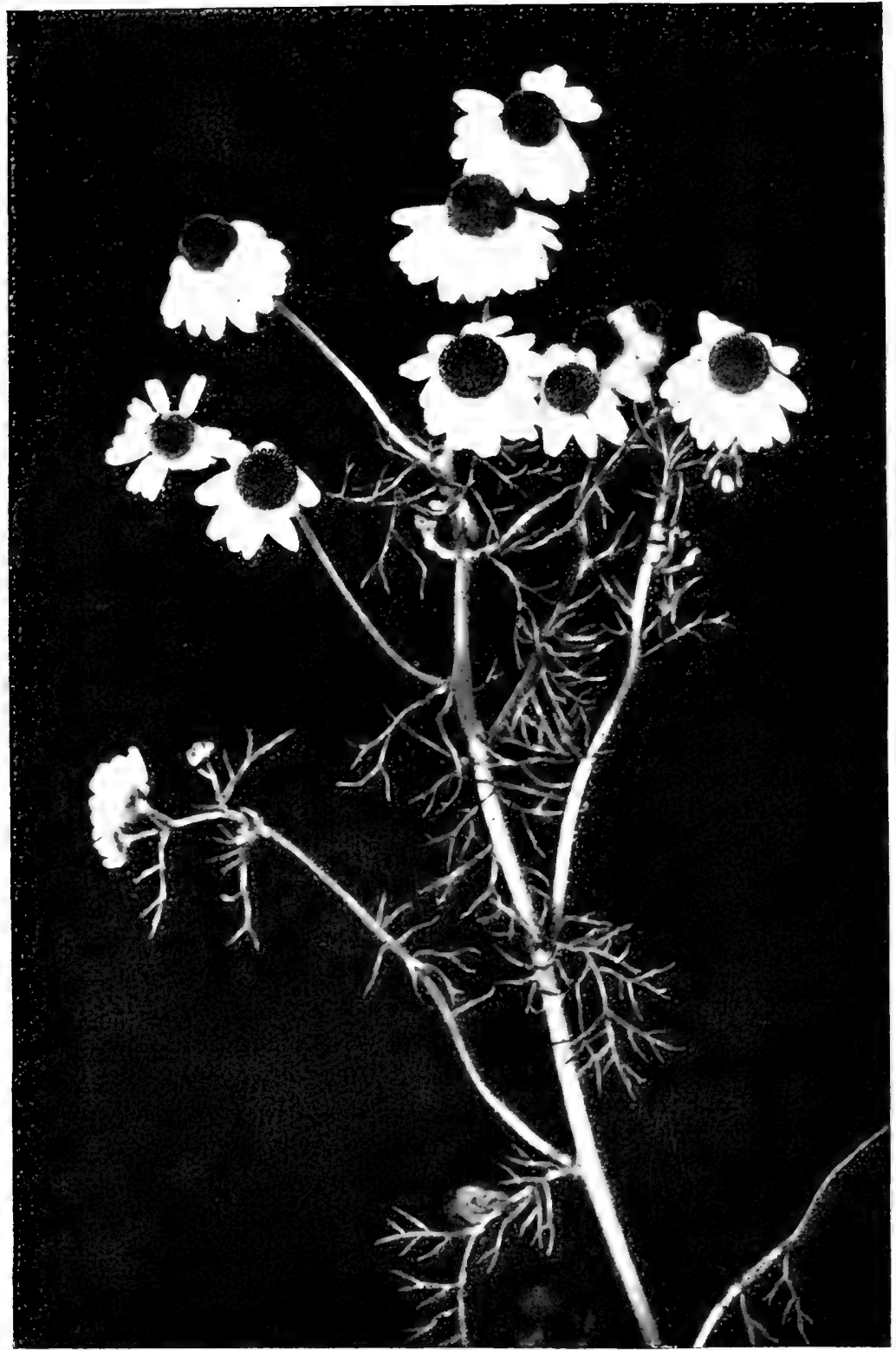

FIG. 7. - THE SAME BRANCH AS SHOWN IN FIG. 6 PHOTOGRAPHED AT 6 P.M. 


\section{THE WILD CAMOMILE}

studying the plant for the preparation of this chapter.

In Fig. 6 (Plate 4) part of a plant is shown photographed about mid-day. In Fig. 7 (Plate 5) the plant is shown again photographed about six p.m. Note how the white florets have now turned back towards the stem. Later at night, or in the darkness caused by an approaching storm, they turn back still more. Now, the field daisy, an almost identical kind of blossom, closes up its white florets at night to protect its central florets from cold and wet. Why does the camomile act in an exactly opposite manner? The answer is, to protect its florets from dew and wet. The central florets of the field daisy are arranged upon a much flatter surface than the camomile, and its florets are more upright, so that rain and dew could accumulate in the tubes and wash out their pollen and nectar. Therefore, the daisy closes over them its outer ray florets. But the tubular florets of the camomile do not stand upright when they open, but lie more or less horizontally, and, moreover, the central mass of tubular florets is more conical and larger than that of the field daisy. Consequently, the outer florets of the camomile could not completely cover the central mass if they closed over as do those of the daisy, and then rain drops that fell in would be driven into the horizontal lower tubes. But by turning the ray florets downwards these conduct the water, which might fall on the somewhat conical centre, to the ground. Furthermore, the camomile takes no risks with 


\section{LIFE HISTORIES OF FAMILIAR PLANTS}

cold and frosts, as it produces its heads of flowers only during the warm months of the year. The field daisy, however, often flowers as early as January, and so needs warmth and protection. This, therefore, is probably the reason why these two very similar flowers act so differently when storms and night approach. 


\section{CHAPTER II \\ THE SYCAMORE "KEY"}

IT is an afternoon in early autumn, and now and again the wind is inclined to be decidedly boisterous, occasionally almost bringing me and my cycle to a standstill. As I am in no particular hurry, and therefore not disposed to contest the point with the wind, I have pulled up on a hill-top, and resting the cycle against the fence, I suddenly discover that my late antagonist has changed its rôle into that of entertainer.

It so happens that I have stopped against a large sycamore tree, and on the side of the hill there is a deep railway cutting, which the tree overlooks. Now, a sudden and extra powerful gust of wind has just bent the boughs of the tree and revealed its foliage in quite different hues by overturning the numerous leaves, and exhibiting more or less of their under sides ; indeed, so strong was that gust that several of the leaves have been altogether disconnected and carried fluttering away into the cutting below.

Besides these leaves, what is apparently a small host of bewildered insects has also been dislodged by this fitful gust. But then I observe that the erratic movements of these apparent insects are almost immediately converted into a 


\section{LIFE HISTORIES OF FAMILIAR PLANTS}

straightaway course, each one whirling along its individual path through space, as though by some surprising instinct it had selected that particular course. Some went flying far away, while others alighted upon the banks of the cutting at no great distance from the tree, just according to the impetus with which they each started off. Also, it at once became obvious that these objects were not insects. In fact, one erratic member has just landed at my feet here, and, of course, it is a winged sycamore seed or, if you prefer it, a sycamore "key."

Yes, the sycamore has finished its season's work. The tree has been exceedingly busy from the earliest hours of spring until now, preparing to meet these blustering winds that suddenly rise in autumn, and now to each worthy gust it offers a number of its offspring; for it may well be said that the sycamore's "keys" are its children. Indeed, while watching each little party start off with each succeeding breeze, I can almost imagine I hear the tree saying, "There, my children, I have done my best for you; now go out into the world and prosper."

What the parent has done for each of its offspring is to provide it with two nurse-leaves which will feed and nourish the baby sycamore plant until it can spread its own leaves out to the sunlight, and send down its own little root into the soil, and so feed itself. Furthermore, the tree has protected each of its seeds and their nurse-leaves by a strong outer covering, one side of which is 18 


\section{THE SYCAMORE “ KEY"}

developed into a flattened wing; and how useful that wing is to the offspring I have already explained in describing how surprisingly the seeds can travel. It is, of course, obvious that large trees like sycamores cannot grow too closely together, so the parent plant provides its offspring with the means whereby it can reach a suitable situation in which to germinate and flourish. We naturally expect that animals will affectionately tend and help on their progeny, but with regard to plants we are apt to overlook how thoroughly their unconscious intelligence conveys to their offspring those features and habits, inherited from their remote ancestors, which have been tested and found good. Their methods are necessarily quite different from those employed by animals, but in their life economy they are none the less potent.

This ingenious method of dispersing the seeds by the agency of the wind may at first seem difficult to account for as a phase of evolution. Here we have a plant producing seeds with remarkable powers of flight, considering that they are only seeds. How did they first become aeronauts and learn to utilise the air to their advantage? Of course, when once the wings had been produced their further perfection would be simply the work of successive generations; since the farther the seeds were scattered from the parent tree, the better chance of thriving would the young plant have, and thus their wings and peculiar method of flight would be further evolved 


\section{LIFE HISTORIES OF FAMILIAR PIANTS}

and strengthened in the offspring that followed. But the point that does not seem so clear is how they came to develop wings at all, for naturally the plant could not discover the use of these organs by premeditation of the matter. Let us trace the development of one of these winged sycamore "keys" and I think it will not only explain how the seed acquired its wings, but will also introduce to us some very fascinating sidelights on sycamore history.

Having thus witnessed the flight of the seeds in autumn, and wondered at Nature's curious methods of attaining her ends, it is, of course, quite easy then to go on our way and forget the matter completely. Let us, however, bear in mind that the fluttering and whirling seed is only the first step in Nature's scheme. When the seed reaches the soil, it is travelling with such force that it often penetrates soft ground, and so gets half sown, and even if it alights upon grass it generally lands low down, well between the numerous blades, rather than on their surface. Then assisted by the rain, and the accumulating débris of autumn, it slowly becomes embedded in the soil, and is seen no more.

In Fig. 8 (Plate 6) we see what happens to the seed that has successfully carried out these first manœuvres. It remains hidden away in the humus and moist soil throughout the remaining autumn and winter months-indeed until the end of March of the next year. Then from the lower side of its rounded end, a delicate and palecoloured shoot breaks through the hard protective 
PLATE 6
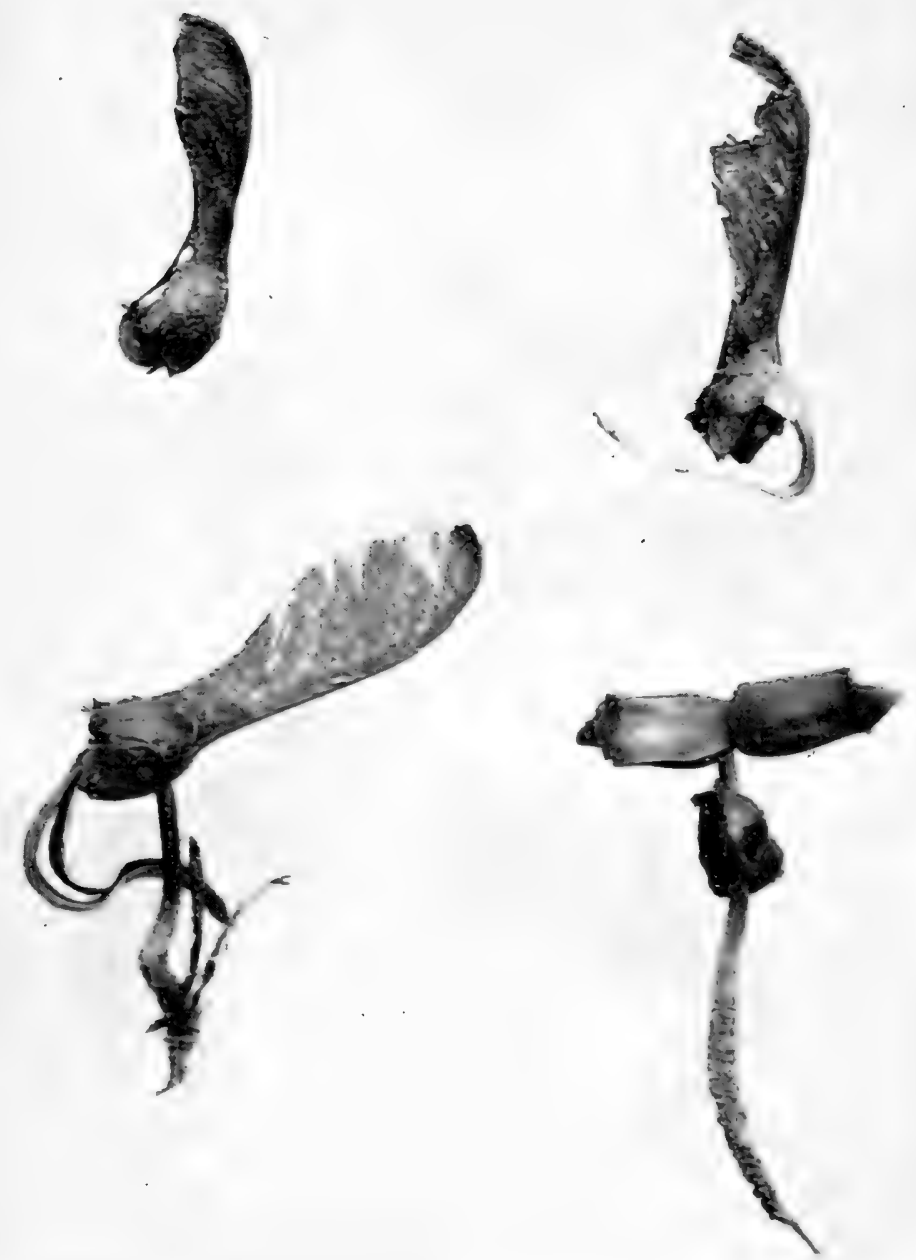

FIG. 8.-SHOWING THE DEVELOPMENT OF THE YOUNG SEEDLING FROM THE SYCAMORE "KEY" 



\section{THE SYCAMORE "KEY"}

skin, which has now become soft and decayed. This shoot is the root of the young sycamore plant just beginning to seek for moisture and mineral substances. In the two upper examples of the figure the root is seen developing from the seed.

On the opposite end to this root are two large and carefully-folded green leaves, and as the young root penetrates the soil, they begin to unfold and spread themselves out to the sunlight. They, like the root, are seeking food; for these leaves can assimilate food material from the atmosphere. In the two lower examples of the figure the leaves are shown unfolding, the final one showing the wing completely thrown off, leaving nothing but the shrunken base still adhering.

The young root works its way amongst the interstices of the soil, and sends up supplies of moisture and mineral matters in solution to the nurse-leaves, which, however, are not the true leaves of the plant; indeed it only needs a glance at their shape as they unfold to see that they are quite unlike sycamore leaves. In Fig. 9 (Plate 7) we see them at the next stage, the example on the right being fully expanded.

The function of the nurse-leaves thenceforth is to assimilate carbon from the impurities of the atmosphere, or, technically speaking, from the carbon dioxide of the atmosphere, the poisonous gas which we exhale in respiration, and thousands of tons of which are passed into the atmosphere. from the chimneys of manufacturing works. The carbon derived in this way is chemically combined 


\section{LIFE HISTORIES OF FAMILIAR PLANTS}

by the leaves with the watery sap supplied by the root, the ultimate product of this combination -in which the energy of sunlight is interwovenbeing energy-yielding starches, and similar food materials, that will build and sustain a young and growing plant.

The nurse-leaves being spread out to the sunlight, therefore, the machinery of growth, as it were, comes into motion, and, consequently, further development proceeds apace. In Fig. Io (Plate 7) the young plant is shown as it appears about the middle of April. It will be observed that the central part is now occupied with two leaves - the first pair of true leaves of the young sycamore tree-and between these leaves is a tiny bud where other leaves are being formed.

Later these leaves will open out, and their place be then occupied with two younger ones. In Fig. II (Plate 8) this further development. is shown. It should now be noticed that the nurseleaves are shrivelling up, and soon they will fall away. The young plant no longer needs nurseleaves, for it now has green leaves of its own with which to capture carbon dioxide, and its root is branching in all directions in the soil and plentifully supplying the necessary sap to manufacture still other leaves. It is true that the leaves have not yet assumed the palmate shape characteristic of the sycamore species, but, nevertheless, each pair now produced gets nearer to the type.

The little central bud steadily persists in producing new leaves for a while, and then from its 
PLATE 7

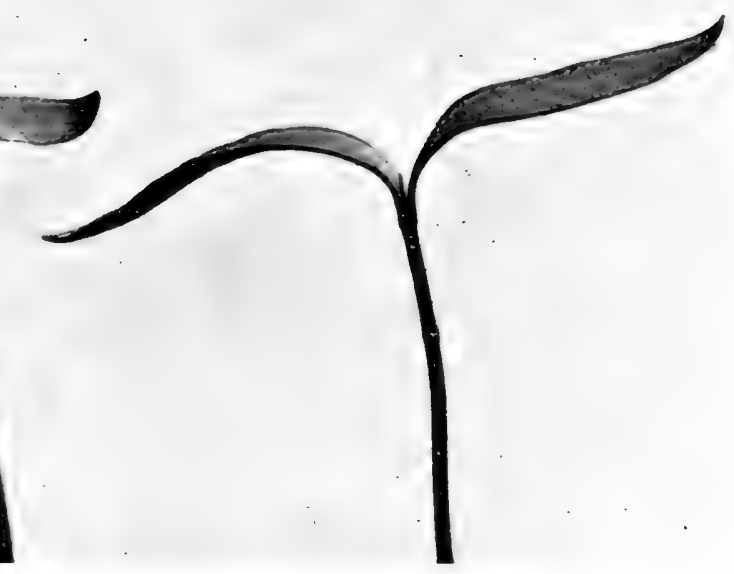

FIG. 9. -UNFOLDING OF THE NURSE-LEAVES

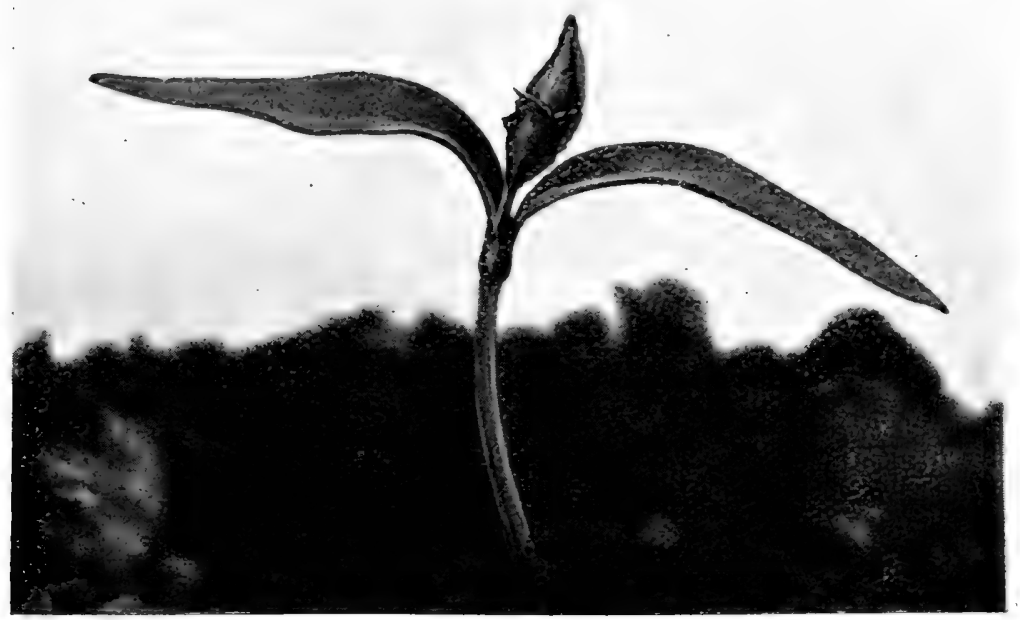

FIG 10. -THE FIRST PAIR OF TRUE LEAVES APPEAR 
PLATE 8
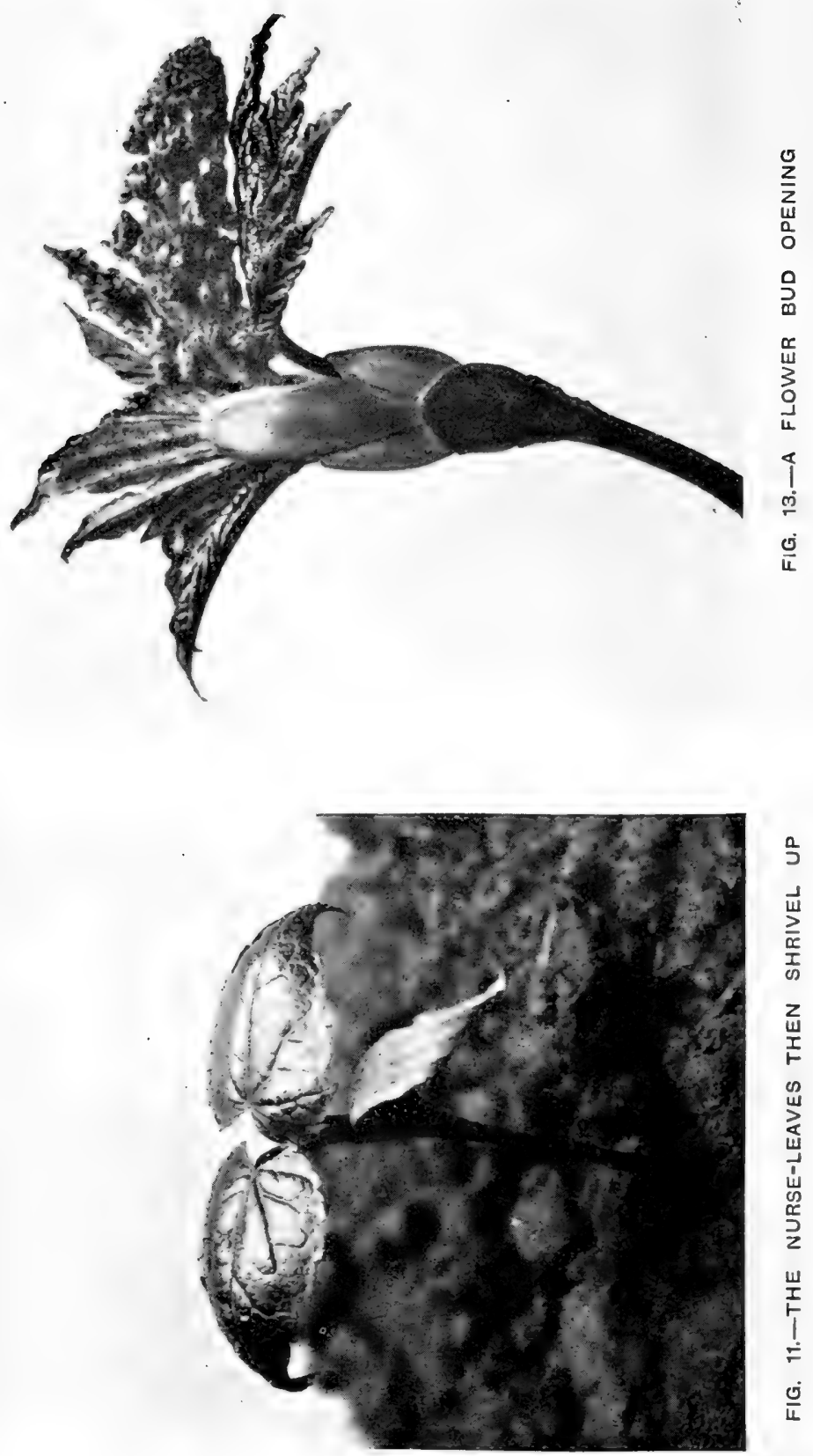


\section{THE SYCAMORE "KEY"}

heart it pushes forward a central branch that bears beautifully-formed leaves in pairs along its length. That tender little first branch may some day be the great trunk of a bold sycamore tree several feet in diameter and encased in strong bark. It may hold above it huge branches bearing innumerable leaves, amongst which several men might successfully hide; but the root and leaves have many years of persistent work to perform before they will have completed a structure of that size. In Fig. I2 (Plate 9) we see the young branches shooting forth from what once were buds, and spreading out their graceful leaves to capture still more carbon and sunlight energy.

When the tree gets on somewhat in years, and has made its structure firm, other important matters besides those of green leaves and branches are developed. In Fig. I3 (Plate 8) is shown one of these developments. Here we see a bud opening and producing something more than green leaves. In Fig. I4 (Plate Io) we see it at a later stage, and there it becomes obvious that a pendent stalk of flowers is being produced. By about the middle of May these flowers have reached their perfection, and I would like you to investigate them with me, not because they are at all striking in beauty or colour (indeed they are small, greenish, and usually very sticky to the touch, and therefore not particularly attractive as flowers), but in order that I may show you how the sycamore produces its winged seeds.

We arrive at our sycamore tree, let us say, at 


\section{LIFE HISTORIES OF FAMILIAR PLANTS}

the end of May, and it is a sunny afternoon with little or no wind. As we reach the tree we observe that the air round about it is swarming with flies; moreover, from the grass and hedges near at hand swarms of flies of many and varied species rise, as we move, buzzing upwards. Why these flies are gathered there becomes obvious presently; they are seeking the sycamore flowers. There are blow-flies, flesh-flies, dung-flies, house-flies, hoverflies, alder-flies and innumerable other species; there are honey-bees, humble-bees, and solitary bees of many kinds ; indeed it is a veritable flies' picnic.

We pull down by means of our walking-stick one of the hanging racemes of flowers, and at once become aware of its strong honey-like scent, and at the same time we perceive that the flowers are quite sticky by the abundance of a sugary substance that they are producing. Why the sycamore entertains this motley throng of insects we have now to see.

In the first place the sycamore's flowers have no showy petals to attract bees, butterflies, and moths; bees are attracted in large numbers, but by the strong, sweet smell of the nectar. In truth the sycamore lays out its flowers especially for pollination by flies; its yellowish and brownish green flowers are a kind of fly speciality, attracting them much more strongly than would brightly coloured flowers. In Fig. I5 (Plate II) are shown some fully-developed examples of the flowers, and a wild bee is seen travelling along one of the leaf stalks. Also in the top left-hand corner is seen 
PLATE 9

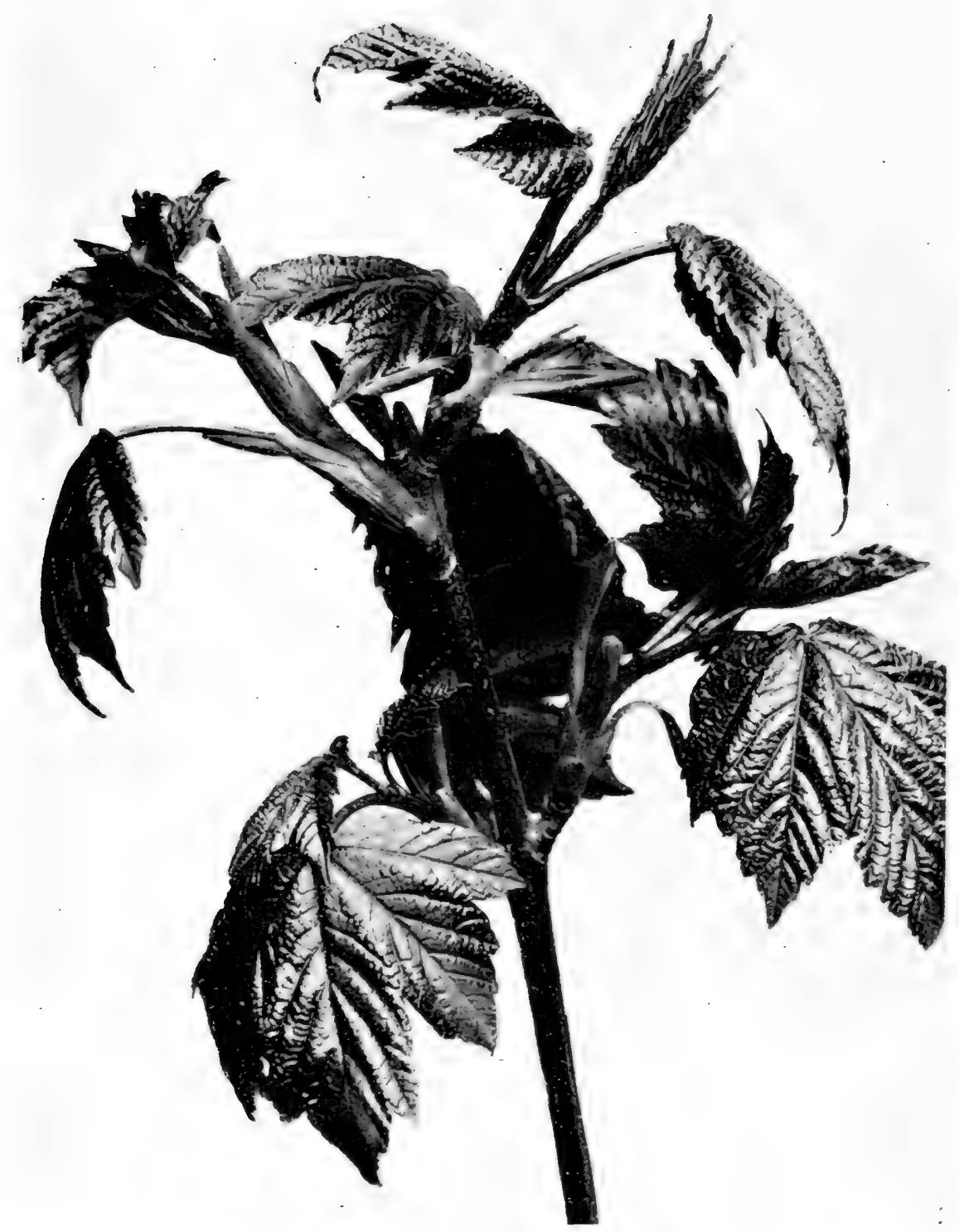

FIG. 12.-YOUNG BRANCHES DEVELOPING FROM THE BUDS 
PLATE 10

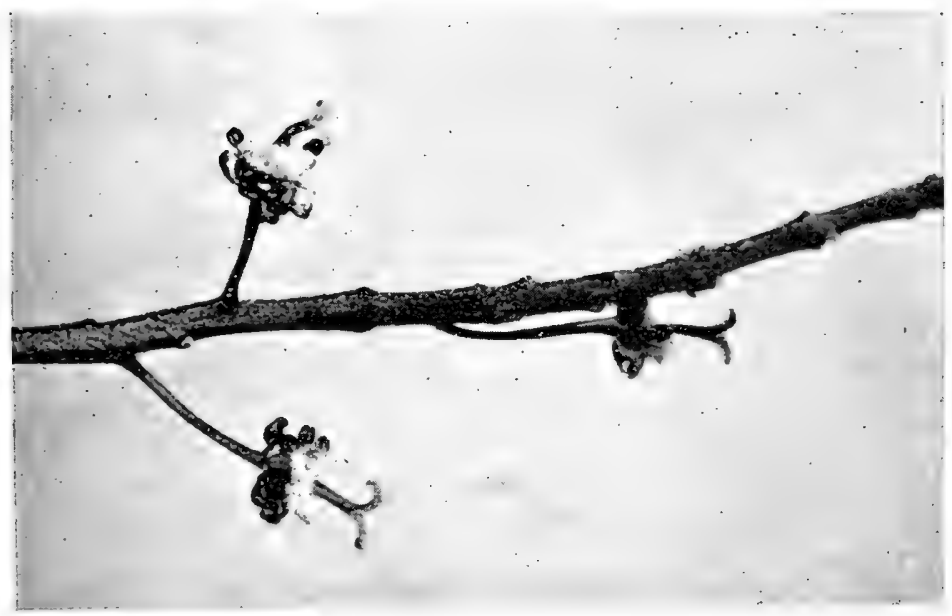

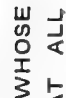

$3 \&$

品

$3_{0}^{2}$

농

品皆

更

i a

$\sum_{0}^{\infty} \frac{1}{J}$

ज茨

I.

@

U.

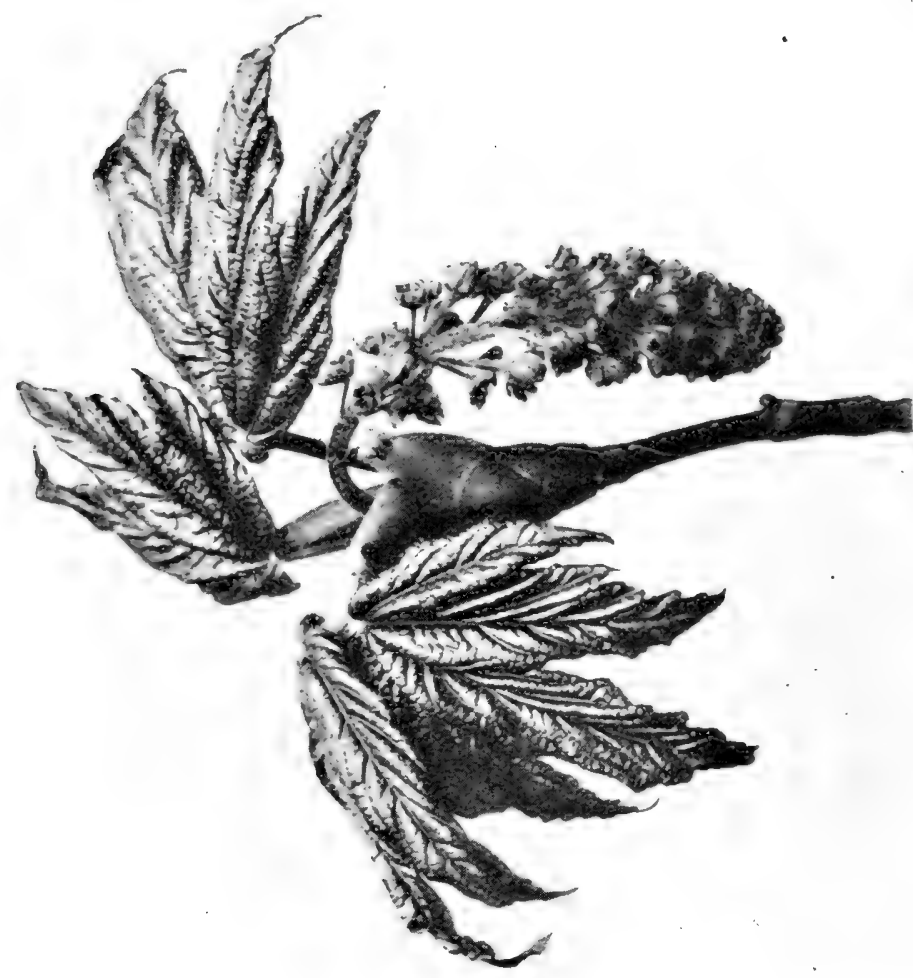

0
0
0

능

$\frac{1}{5}$

5

늠

삔 


\section{THE SYCAMORE "KEY"}

another of these bees engaged in seeking the nectar and pollen of the flowers. (I may say here parenthetically that when these insects are busy amongst the flowers it is very difficult to show them in a photograph, since their colours so closely resemble those of the flowers themselves.) The illustration will, I think, show clearly that each little flower has put forth numerous stalked stamens, or pollen-producing organs, and when the bees and flies climb up the hanging bunches of flowers, they become dusted with fertilising pollen. By the time a fly has travelled over the flowers of a well-developed shoot, his natural colours are more or less obliterated by the yellow dust from the stamens.

Now, when a spray of flowers appears, the first flowers to open generally produce large quantities of pollen; in fact, they are frequently devoted entirely to that purpose, and after performing that function they fall away and perish. Other flowers higher up the stalk, however, when they first open develop like those shown in Fig. I6 (Plate I0), producing first a central object divided at its apex, but with stamens which either come to maturity later, or not at all. Having now grasped these little details of the floral structure, we shall, I think, understand what part the fly, as dusty as "the miller of the Dee," plays in the sycamore's scheme for pollination.

The base of the central objects shown in Fig. I6, and previously referred to, will be seen to be 
pale-coloured (owing to its being covered with tiny white hairs) and divided into two lateral pointed parts; behind these are pollen-producing stamens just developing, and farther behind are the enclosing green parts of the flower. Of course, a fly or a bee, dusted well with pollen, on reaching these later-developed flowers, instead of clinging to the stamens as it moved amongst them-as it is seen doing in the top left-hand corner in Fig. I5 (Plate II)-would have to hold to the central object in each flower while it searched for nectar around the base of the hairy part below. Now the divided part on the end of this central object is both rough and sticky, and as the fly rubs against it some of the pollen is sure to be conveyed to it. In fact, if you saw it under a magnifying lens after a dusty fly had visited the flower, it would appear as shown in Fig. I7 (Plate I2), the irregularities on its surface being due to the tiny pollen grains adhering to it.

Having consumed all the available nectar, the fly then leaves the flower to visit another bloom, still carrying plenty of pollen with it to pollinate other stigmas, or its next visit may be to a branch where pollen only is being produced, and there it will gather more of the fertilising element. And that is what the fly has been doing for the flower; it has pollinated its stigma, which then permits the ovary to develop until it becomes-what? That we have now to witness.

The plant has produced an abundance of flowers, each of which was well provided with 26 


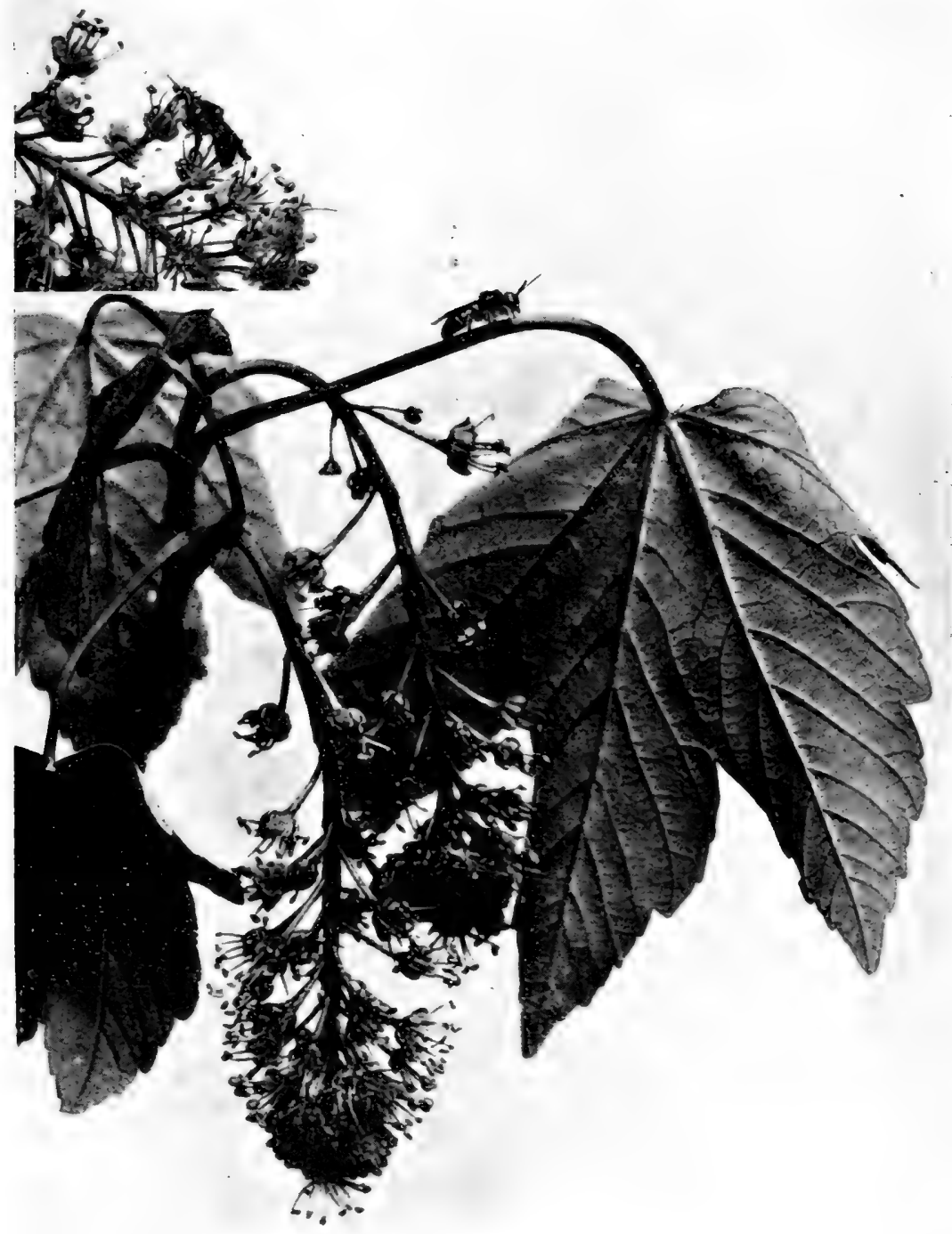

FIG. 15.-THE FLOWERS ATTRACT SWARMS OF FLIES OF MANY SPECIES. INSET SHOWS A WILD BEE FEEDING ON THE NECTAR OF THE FLOWERS 


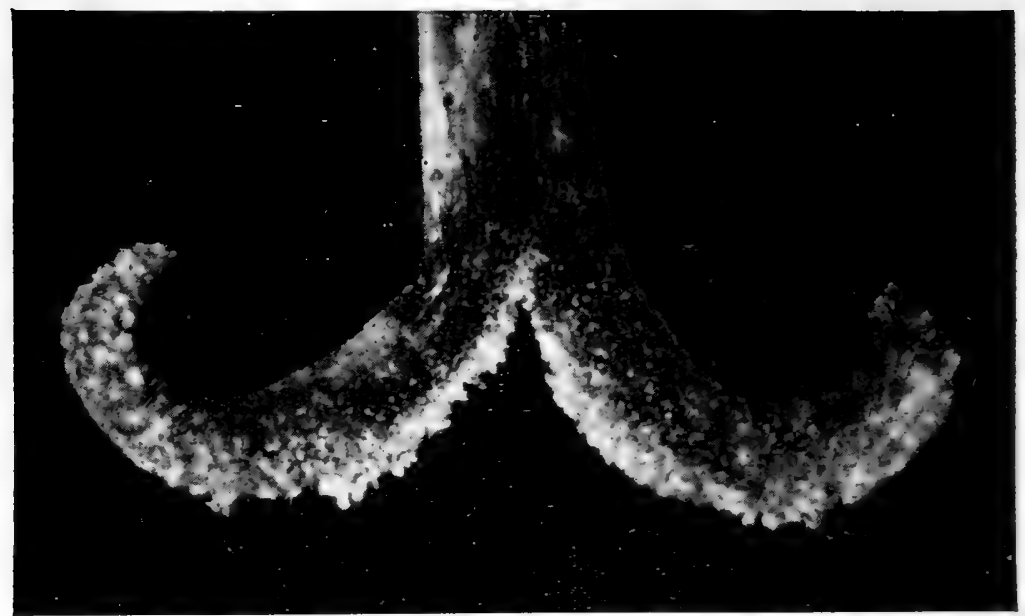

FIG. 17.- STIGMA AFTER HAVING BEEN VISITED BY A FLY SHOWING THE POLLEN GRAINS UPON IT (magnified) '

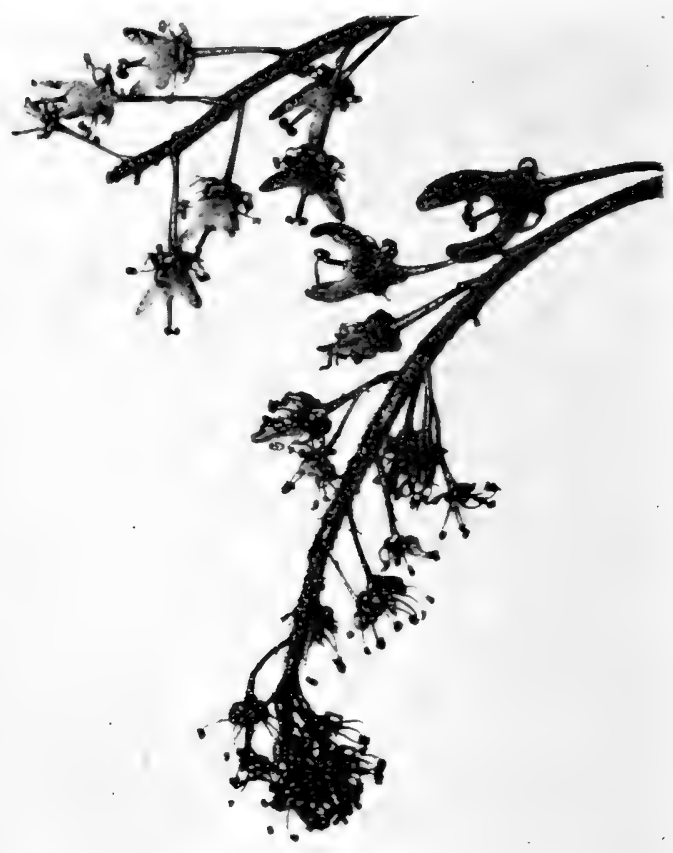

FIG. 19.-SHOWING HOW THE FLOWERS SLOWLY CHANGE INTO SYCAMORE "KEYS" 


\section{THE SYCAMORE “ KEY"}

nectar; some of these flowers bear only pollenproducing stamens, but some have gone farther and produced in addition a central ovary, protected with tiny hairs, in which seeds were to be matured after the pollen-dusted fly had paid a visit; for when the stigma is pollinated fertilisation begins, and so the seeds become perfected and continue their development.

These devices for attracting fly visitors the plant has slowly evolved through having derived benefits from their incidental visits, and the principle of producing some flowers that have no ovary, and others whose stamens never come to maturity, together with flowers which mature both stamens and ovary, is a very economical one. It insures that some flowers, at all events, will be cross-fertilised instead of being fertilised from the pollen of their own flowers. In the course of time it is quite possible, I think, that the sycamore will dispense altogether with flowers that produce both stamens and ovary together, and so make all its flowers distinctly male or female, and thus insure cross-fertilisation for all its seeds. Cross-fertilisation, as has been already observed, produces much stronger offspring than self-fertilisation.

The sycamore therefore presents an exceedingly interesting example of a tree slowly evolving flowers of one sex only, or what the botanist terms unisexual flowers. Many trees have completed their evolution in this direction, for example, oaks, alders, hazel, etc., while some, as the willows, have 


\section{LIFE HISTORIES OF FAMILIAR PLANTS}

gone even farther and now produce flowers of one sex only on each tree, leaving to insect agency the conveyance of pollen from the male tree to the stigmas of the female. So highly is crosspollination valued in plant life.

In regard to the insects a!so, this evolution presents some fascinating sidelights. In Fig. I8 (Plate I3) are shown a few of the hairs on the body of one of the bees seen in Fig. I5 (Plate II), magnified about 350 diameters, and it is interesting to notice the pollen grains adhering to them, assisted by delicate branches from the main hairs; for these hairs are not simple hairs, but hairs specialised to conveniently carry pollen from flower to flower. It need scarcely be said that if the plant evolves devices that assist the bee, the bee will evolve measures of a reciprocal character. This is just a hint of the many interesting aspects of this fascinating subject.

But we have not yet discovered how our sycamore "key" is produced. In Fig. I9 (Plate I2) may be seen the "keys" in the process of manufacture. You will notice that at the end of the lowermost shoot are some male flowers (i.e., bearing stamens only), but higher up on the same shoot there are others in which, if you look closely, it will be seen that the part bearing the stigma has shrivelled up and the ovary at the base has enlarged into a two-sided winged object. In fact, when they grow a little larger, each one of these flowers will form a pair of sycamore "keys." The process of change is more apparent in the 
PLATE 13

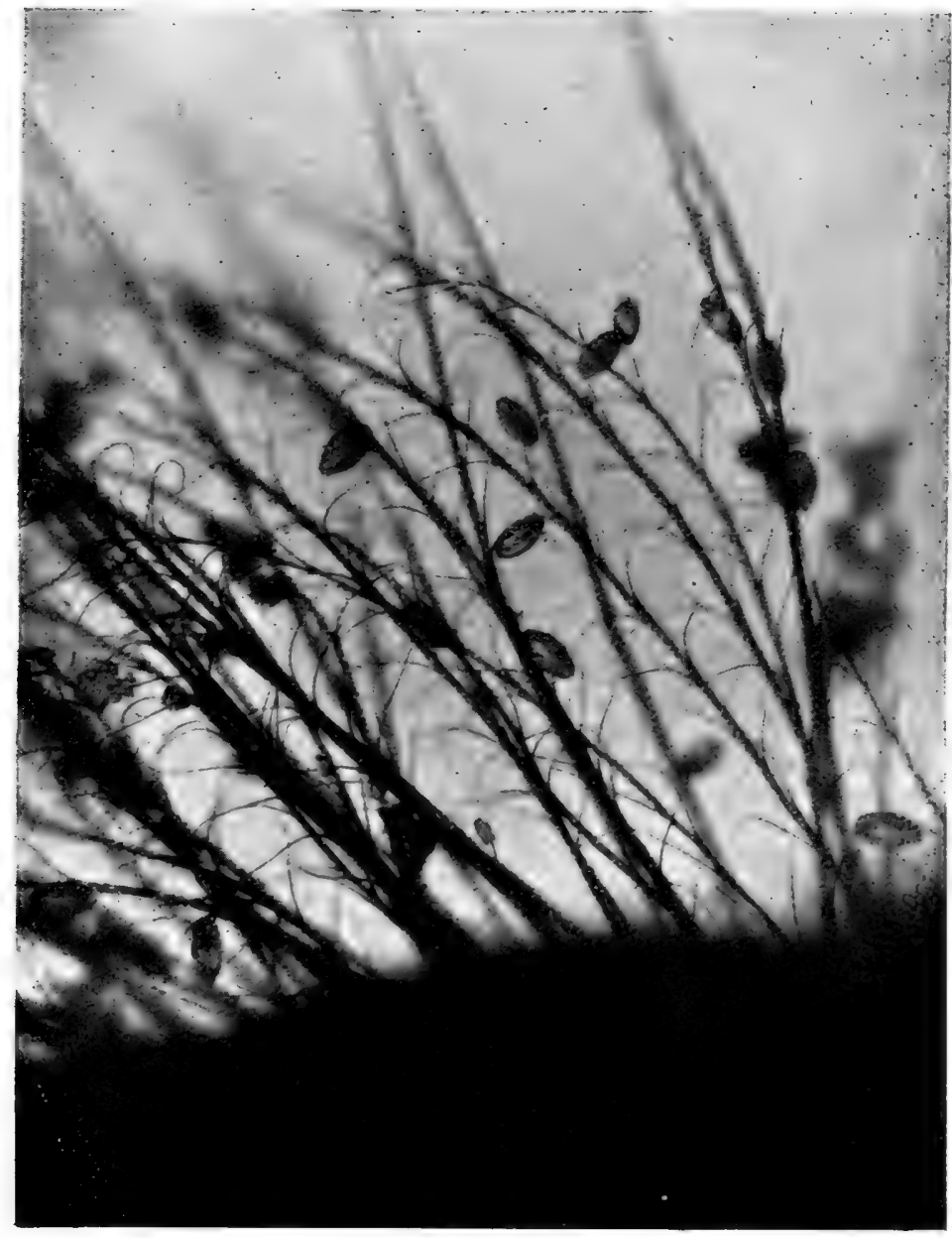

FIG. 18. - HAIRS FROM BODY OF A BEE, SHOWING POLLEN GRAINS ENTANGLED (greatly" magnified) 
PLATE 14

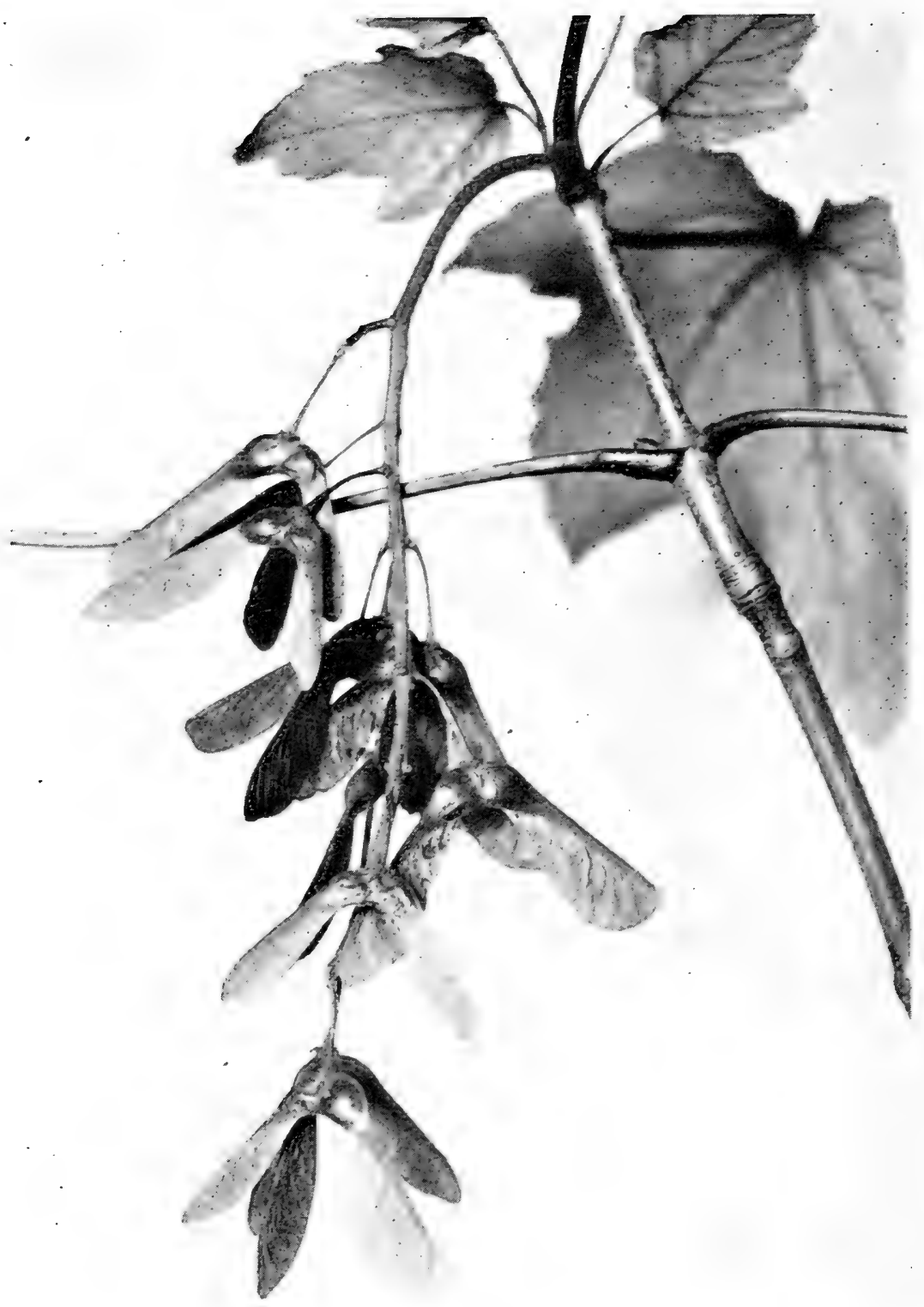

FIG. 20.-THE COMfLeted WORK AT THE END OF AUGUST 


\section{THE SYCAMORE “ KEY”}

upper example, where each hairy ovary is seen slowly developing into two winged seeds. In Fig. 20 (Plate 14) the work is seen completed, and I scarcely need say that in each of these winged seeds there is a little seedling plant, for have we not previously seen one develop from such a seed ? If you need further convincing, you have but to anticipate Nature by carefully cutting open with the point of your penknife the rounded base of a fully-developed seed, and there you will find the little plant carefully packed away, and you may poke it out and unfold its nurse-leaves, as these are quite large enough for you to examine with the unaided eye.

There now only remains the question: how the seeds should have developed wings to soar upon the wind? Well, the answer is exceedingly simple. The ovary, to begin with, is flat and divided into two halves, each bearing a thin edge at its upper corner. Now, naturally, some seeds would, in the early stages of the sycamore's history, occasionally be thinner and flatter at their corners than others, and when the time came for the seeds to fall from the parent tree, these thinnest seeds would get carried farthest by the wind, and would consequently stand the best chance of prospering, and so from these early and accidental examples have been slowly evolved the more efficient forms, until to-day we have the seed, or "key," as we know it.

Finally, how was the graceful whirling flight of the seed acquired? Well, that, I think, is 


\section{LIFE HISTORIES OF FAMILIAR PLANTS}

equally plain. Naturally, a seed winged only on one side, or with nearly all its weight in one direction, owing to its centre of gravity having an eccentric position, would spin in falling; hence, as the seed has developed and broadened its wings, this gyratory movement has continued, and probably been strengthened from the fact, which I have previously pointed out, that it helps the seed to penetrate the earth when its flight is suddenly interrupted. 


\section{CHAPTER III}

THE COMMON ARUM, OR CUCKOO-PINT

(Anum maculatum)

SCIENCE has not only routed the view, once universally held, that this earth of ours is the centre of the whole universe, but has destroyed many closely-related notions as well, such as that the beauties of Nature are designed especially to minister to the æsthetic tastes of mankind. Of course, man may still, if he chooses to delude himself, assume that the beautiful forms and colours of natural objects are there to gratify his eyes and gladden his heart, but the fact remains that the slightest scientific investigation in any direction will soon prove to him that, although these things may brighten man's path through life, yet this is only incidental to their real function-Nature's finishing touch, as it were, the touch that makes the whole world kin.

Even the green colour of the grass has its specific function, and so, likewise, has every tiny hair or spot of colour that accompanies a flower or appears on stem or leaf; and the function of an organ is always associated with the interests of the organism itself. Therefore, when a flower secretes rich nectar or honey, and sends forth sweet perfumes, at the same time developing 


\section{LIFE HISTORIES OF FAMILIAR PLANTS}

showy petals further to advertise the fact that the nectar is there and ready for all the winged insects that care to come to the feast, it is really doing something entirely in its own interests, and not providing these things for the gratification of man, or even of the insects, for that matter; the insect is catered for by the plant only so far as the latter serves its own ends. To put the matter briefly, the plant needs the help of the insect to convey its fertilising pollen from bloom to bloom to make its seeds fertile, and bribes with nectar to gain this end. Beyond that point the plant's interest (if we may term it such) in the insect absolutely terminates.

Now, in our rambles during May we are almost sure to find in the moist woodlands, or by the watery ditches, blooms of the curious wild arum, cuckoo-pint, wake-robin, lords-and-ladies, as you may like to call it, some of which are illustrated in Fig. 21 (Plate 15), and the plant more in detail in Figs. 27 and 29 (Plates 18 and 19). We shall be struck by the quaintness of the form and colouring, for the arum is one of the most singular plants in the British flora. However, before going into particulars regarding this extraordinary floral structure, I want to take you back to the beginning of things, and show how the plant started its career. But, first, let me mention a little secret regarding the bloom itself.

When a bloom is found fully opened, like that shown in Fig. 27 (Plate I8), it will be observed that it narrows off to form a kind of neck just below 


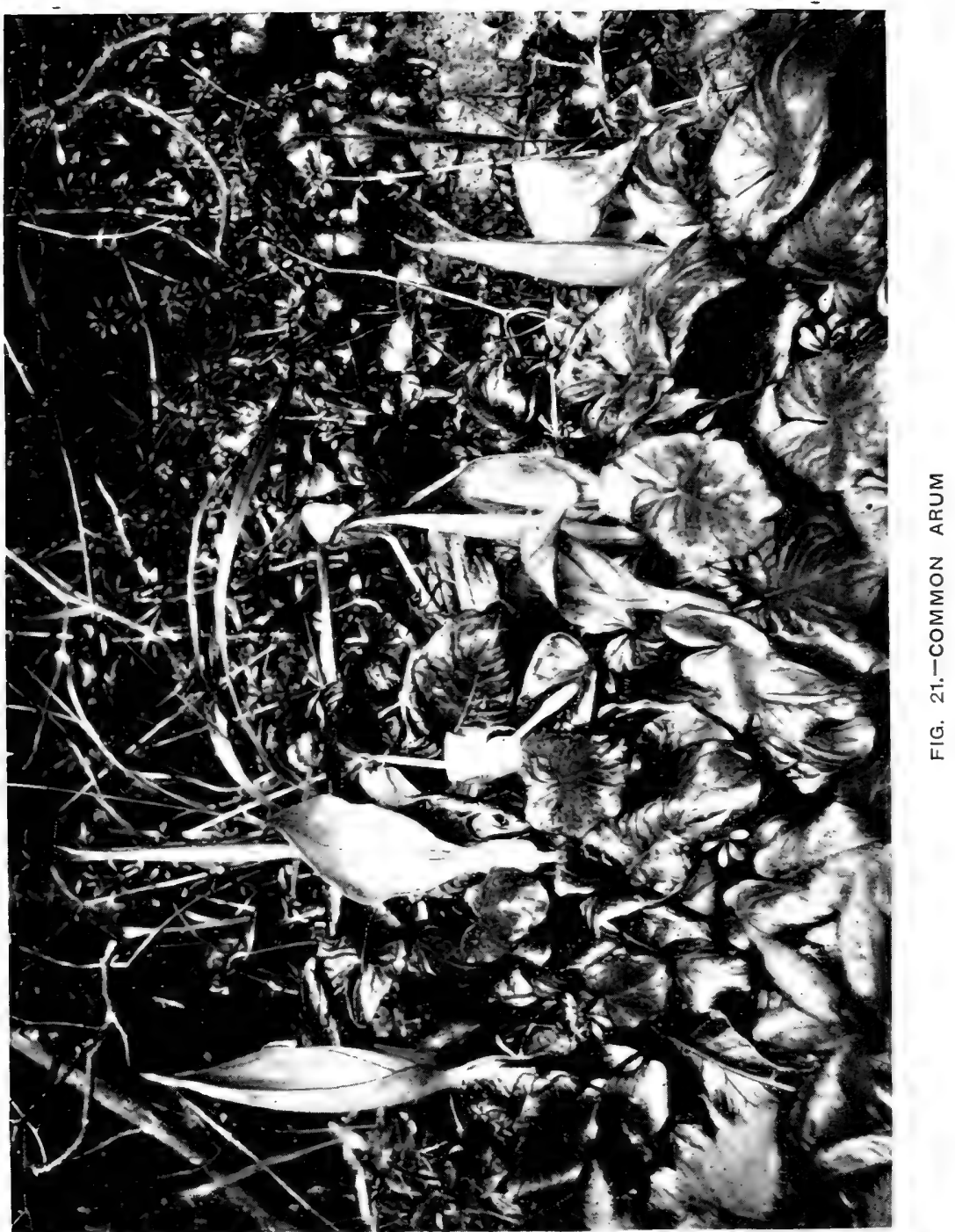





\section{THE COMMON ARUM}

the central portion, and then swells out again forming an oval-shaped sac, as is well shown in the illustration. Now, having obtained such a bloom, cut a tiny portion from the substance of the sac with a sharp penknife, so as to make a small hole. Then turn the hole towards the sunlight and watch what happens. Through the opening will come a tiny midge-fly, which at once takes to its wings and disappears from view. Its place, however, is immediately taken by another fly, and presently, still others appear, until at last a veritable army of midge-flies is trooping through the hole. It is rarely that one can find a fullydeveloped arum without its army of tiny midges within. How came these flies there, and what are they doing? These are questions I will endeavour to answer later; meanwhile we have to learn something of the early history of the plant.

The arum plant, as we know it, may start life from a seed, but it more often develops after the manner of the cultivated potato, and, instead of producing a new plant, simply continues the growth of the old one by means of underground tubers. For, of course, a potato is not a seed, but simply a swollen end of an underground stem, bearing buds, so that when a "new" plant is produced from it, it is really the continuation of the growth of the original plant, growth having been deferred at the tuber or potato stage. Such a plant may be likened to the "new" plants produced by the runners of the strawberry, which are 


\section{LIFE HISTORIES OF FAMILIAR PLANTS}

also only continuations of the development of the original stock. A new plant, properly speaking, is one developed from a seed, for the seed is a sexual product of two parents of the species, a male and a female. Arum plants, then, are spread either by tubers or by seeds.

In Fig. 22 (Plate I6) we see, as it appeared on a certain April 5th, one of the little tubers produced underground by an older plant. It has developed roots below, and above has budded out a single leaf. The rich stores of nourishment in the little tuber gave the plant a good start in life, and as the roots developed below ground, growth went on apace above, and some eight or nine days later the leaf began to assume its permanent form (Fig. 23, Plate I6). A little later still, another leaf was formed to accompany it (Fig. 24, Plate I6). By early May a third leaf had appeared, and, in addition, a curious central object that tapered to a sharp point (Fig. 25, Plate I7).

Then the work of the three leaves was to spread themselves out to their fullest extent to the sunlight, for they have the power of absorbing energy from the sun's rays; and this energy is largely utilised in the building processes of this allimportant central object, which meanwhile was rapidly progressing. By May I6th it had become quite an important part of the plant (Fig. 26, Plate I7), and was unfolding its structure to the light. Within was a curious, purple-coloured, club-like organ, and the sheath or hood surrounding it was of a pale green colour, tinged also with 
PLATE 16
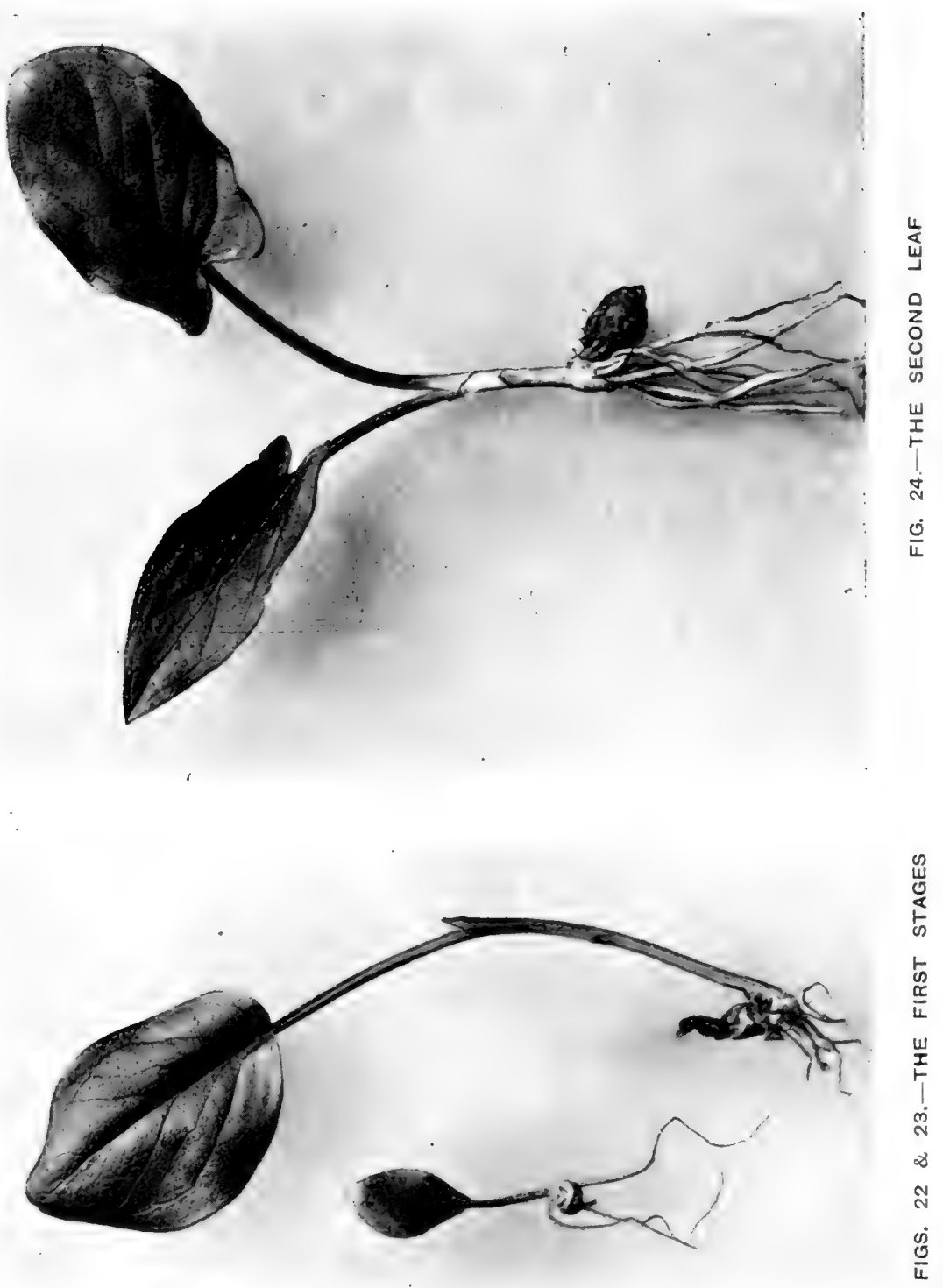

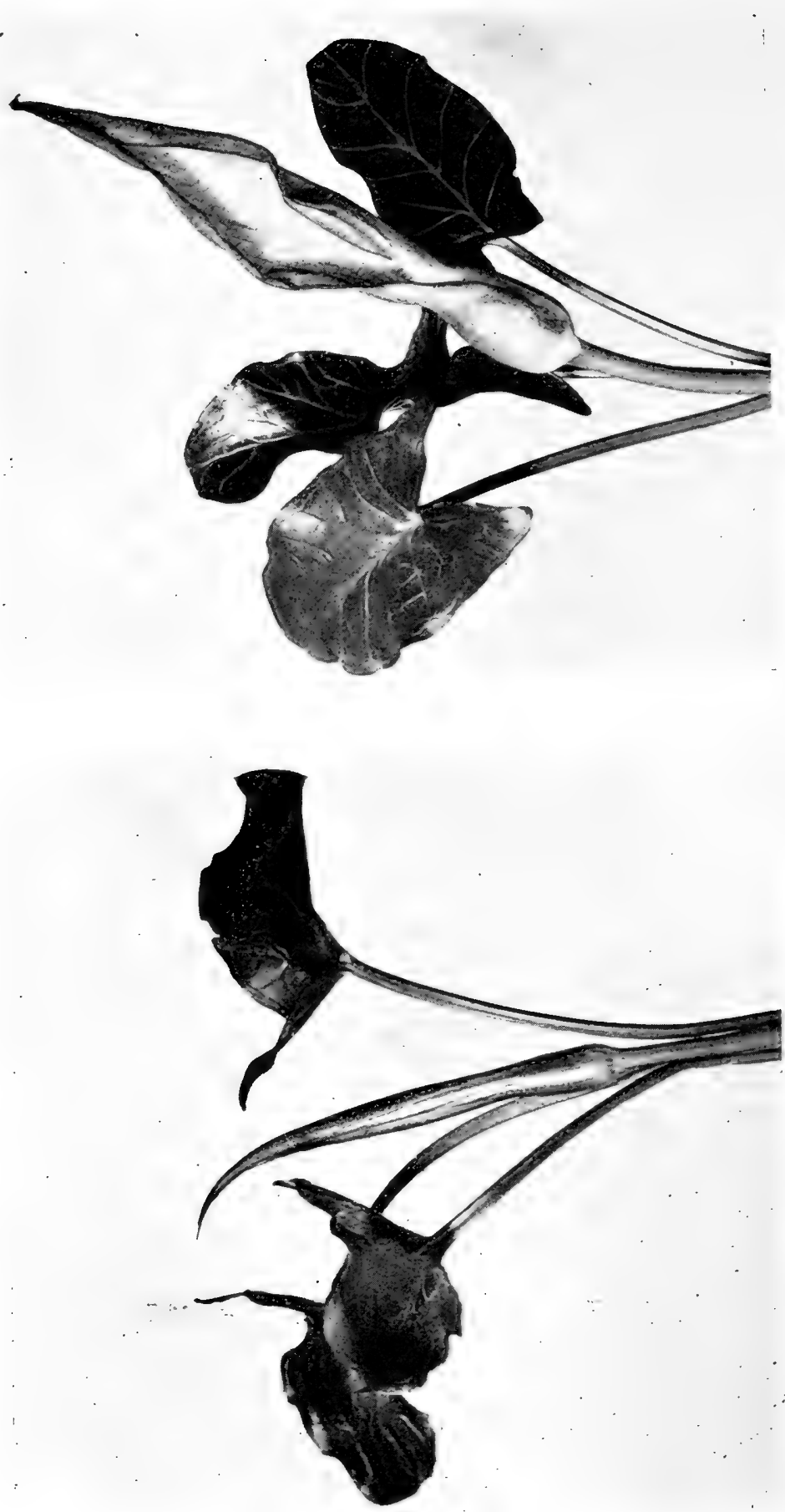

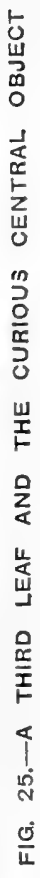




\section{THE COMMON ARUM}

purple. It was on May Igth, though, that it reached its perfection (Fig. 27, Plate I 8).

What did all this mean? What was the purpose of this most quaint floral structure? No butterflies or moths were ever seen to visit this extraordinary-looking blossom; the whole plant had a weird and uncanny look. Its glossy dark green sagittate leaves contrasted strongly with the pale-coloured hood of the bloom, tinted within with a purple hue, against which stood out conspicuously the purple club; the whole plant, too, is very poisonous, and the odour from it, although not powerful, is certainly not inviting. Still there are living things that know full well how to appreciate that mysterious blossom, for within the lower part of our bloom was a merry throng of tiny midge-flies, such as I have previously referred to, in the midst of a revel they dearly loved.

The particular little midge that patronises the arum in England, has no common name, but, to distinguish it from other species of midge-flies, I will (at the risk of being accused of making a big fuss about a very small thing) give its entomological name, which is Psychoda phalcenoides. Probably you will not appreciate the insect any the more for this information, but, nevertheless, when you find it you now have its name ready for it. The little insect is a near relative of the common gnat, and is familiar everywhere during the summer months. A magnified photograph of it is shown in Fig. 28 (Plate I9). With wings closed 


\section{LIFE HISTORIES OF FAMILIAR PLANTS}

it would about cover the space of a pin's head, and it is very commonly seen hopping and fluttering about in a curious, jerky fashion on windows of outhouses and similar places, but it is very difficult to catch.

Concerning the life history of the species, very little is known, yet it is certain that when arums are blooming these midges give little time to anything besides drunken orgies within their shelter. You have only to cut open a bloom at the narrow neck portion and look down to the lower part to see the helpless insects lying in heaps, all more or less intoxicated-intoxicated from over-indulgence in arum nectar. Indeed, they are often almost completely buried in the yellow pollen dust that falls from the stamens, their hairy feelers, legs, wings, and bodies being so thickly covered with it that the insect looks twice its natural size when it leaves the bloom. The temperature, too, inside this enclosed area where the flies are found, is much above that of the external atmosphere, often from ten to twenty degrees higher.

Therefore, in this balmy warmth, with abundance of the nectar they love so much, they, like drunkards, give themselves over entirely to indulgence, doubtless completely forgetting the external world. However, as soon as you cut open the bloom and let in the cooler air, they quickly one after the other begin to revive and shake from their bodies and limbs the thick coats of pollen they have accumulated, and then take to their wings, for they are good fliers. 


\section{PLATE 18}

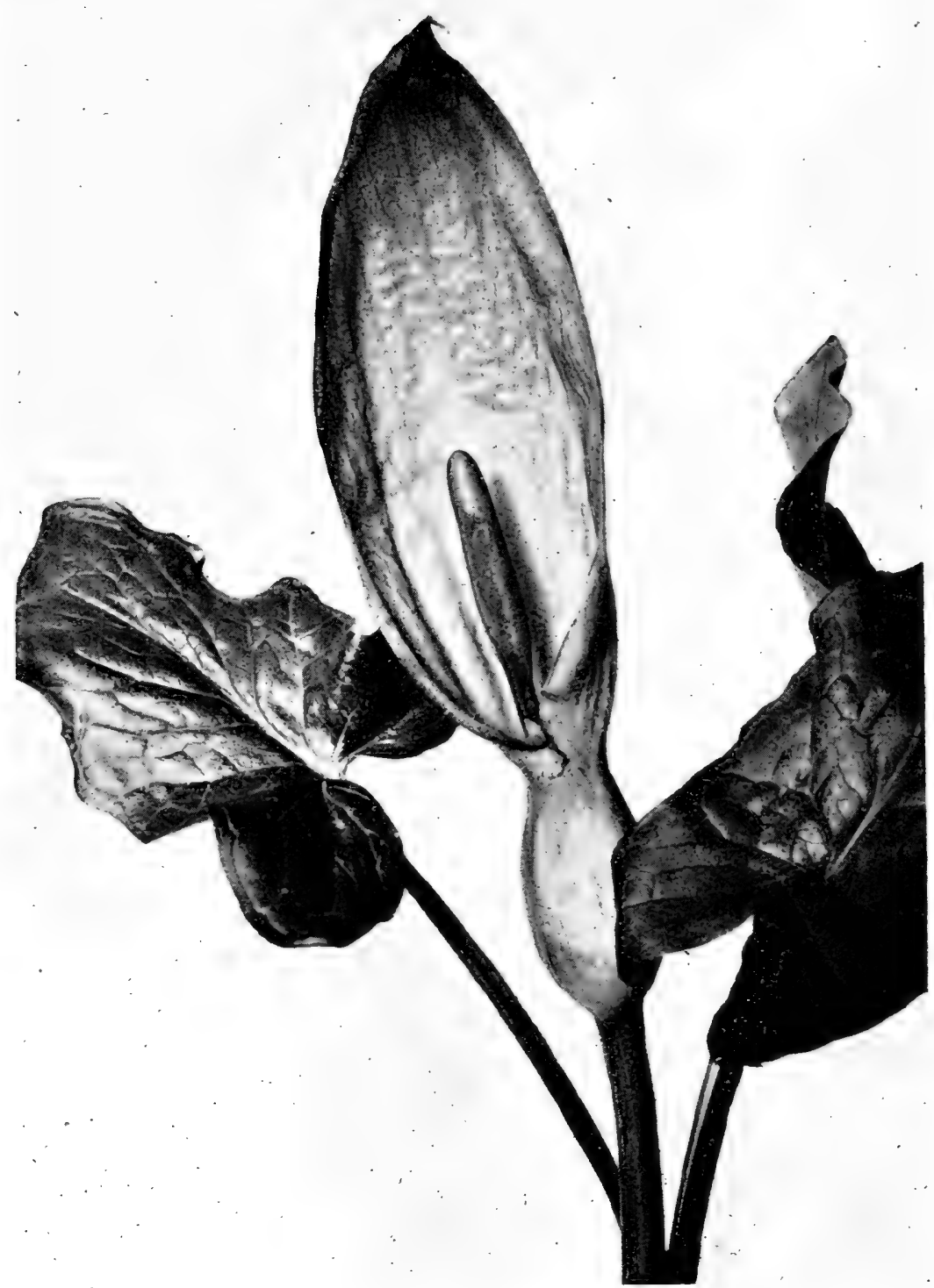

FIG。 27.-THE FULLY-DEVELOPED ARUM 
PLATE 19

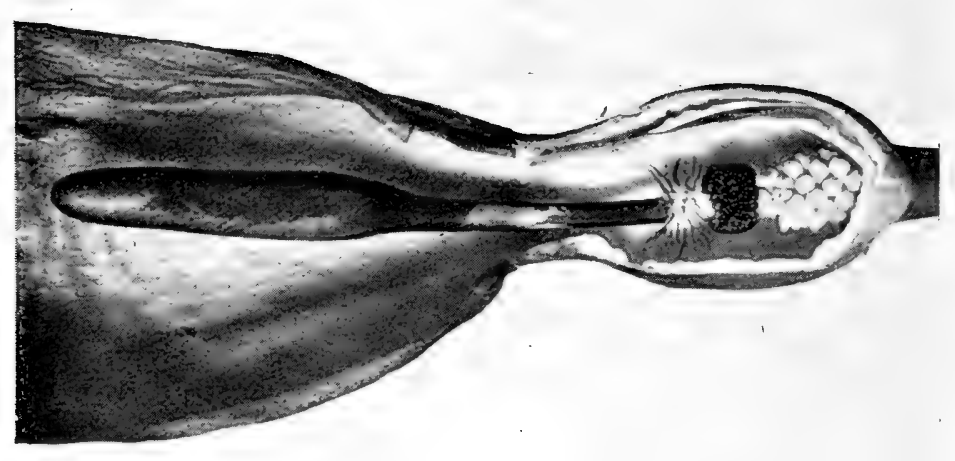

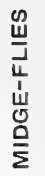

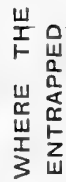

觉

舟

I

U

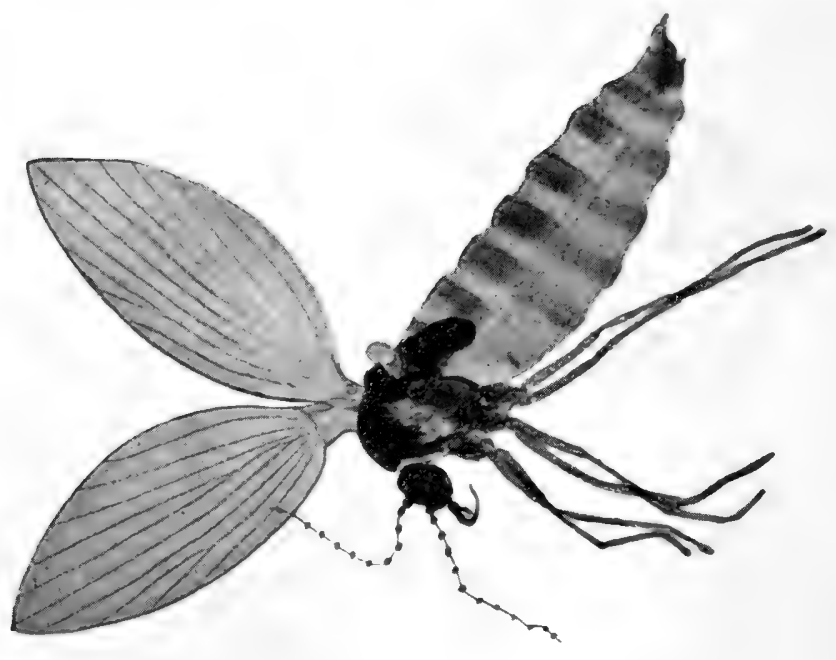

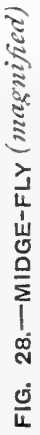




\section{THE COMMON ARUM}

Now that we have followed the arum through its development to the flowering stage, and have incidentally discovered that it provides a royal feast of nectar, often for several hundreds of midge-flies, we may go farther and endeavour to find the reason of the arum's generosity in this direction.

Like other living things, the arum does not work for nothing, nor does it produce nectar for midge-flies out of kindly feeling towards them. We might almost say that the arum's scheme for entrapping these little flies is a most artful one, and more like the ingenious work of a thinking animal than the blind instinct of a mindless plant.

In the first place, the arum bloom is not a flower, but what the botanist terms an inflorescence, that is to say, it is a branch of flowers; just as a shoot of foxgloves is not a flower but an inflorescence, or a branch of flowers. In Fig. 29 (Plate I9) we see one of the blooms cut open, the illustration showing it just before it reaches the stage when the midges visit it. Now, I have pointed out in the first chapter that a perfect or complete flower consists of four whorls, the green sepals, the coloured petals, the stamens which produce the male fertilising pollen, and the central carpels, or unripe fruits, to the surface of which the pollen is conveyed in the process of fertilisation. But a flower need not always possess all these parts; almost any whorl may be missing. However, the stamens and 


\section{LIFE HISTORIES OF FAMILIAR PLANTS}

carpels are essential, although, as we have seen in the case of the sycamore flowers, they need not necessarily be in the same flower. One flower may have sepals, petals, and stamens, but no carpels, when it becomes a male flower; another flower may have sepals, petals, and carpels, but no stamens, when it becomes a female flower. In such cases the pollen is generally conveyed from the male to the female flower by means of the insects that visit them alternately. The simplest and most primitive kind of flower consists of a single carpel or ovary that produces a seed, or a single pollen-producing stamen, without any sepals or petals around it, and this is what we have in the case of the arum. The arum possesses many flowers, botanically speaking, but it can scarcely be said to possess anything worthy of the name in its popular acceptation, although the inflorescence as a whole partly atones for its delinquencies.

If, now, we look carefully at Fig. 29 (Plate I9), we shall observe that, at the lower part of the purple club, in the area where the midges are entrapped, there are three kinds of small bodies. Lowest of all are pale-coloured roundish objects ; each of these consists of a single carpel containing an embryo seed. Above these are some smaller, curious, purple-coloured knobs, which when mature burst open and shed quantities of yellow pollen dust. From what I have previously said, it is plain, then, that we have here two groups of the simplest of flowers, just a single stamen, or a single 


\section{THE COMMON ARUM}

carpel, without any other floral parts. Above these groups of simple male and female flowers we find some other bodies shaped like the lower female flowers, but from their surfaces appear long bristles which stand out from the axis and point downwards. These objects are really abortive female flowers modified to serve another purpose in the plant's economy-and of these more will be said later.

Now that we understand the various parts which constitute the quaint floral structure of the arum, we may proceed to see what connection they have with the tiny midges that so love to visit them.

The purple club is the sign-post that attracts the midges, for it is, of course, quite a conspicuous object as it stands against the pale green hood that envelops it. So presently the arum-seeking flies come along and espy the familiar sign-post. Not a moment is lost. They steer quickly for it, alight upon it, and gleefully descend until they reach the narrow neck portion, where they meet the bristly abortive flowers. These latter, with their bristles pointing downwards, prove no obstacle to the midges so they travel down to the base of the flower.

Many of the insects have just come from other arum blooms in the near neighbourhood, and about their wings, legs, and bodies they carry traces of their previous feastings, in the form of minute pollen grains. When, though, they reach an arum at about the stage of that shown in 


\section{LIFE HISTORIES OF FAMILIAR PLANTS}

Fig. 29 (Plate I9), they meet with disappointment, for the arum contrives to induce the midges to enter the bloom before its pollen and nectar are mature. So, when the insects reach the base of the bloom and find no nectar there, they have plenty of time to sober down and perhaps repent the foolishness of their past orgy. In fact, this period of fasting after one feast often lasts so long that they become really hungry.

Of course, you will ask: Why then do not the flies leave the bloom? They undoubtedly would if they could, and they travel up and down the central axis many times, doubtless with that intention, but when they reach the bristles in the narrowed neck of the bloom they find that, although they could travel down them freely enough when they entered, yet they cannot return the same way, for the bristles point downwards and form a perfect barrier against their leaving. Indeed, they are prisoners until the arum chooses to release them. There is often ample room for such tiny flies to travel up the sides of the hood, and so miss the bristles, but they make no attempt to escape in this manner; it may be that the hood is too steep and smooth for them to climb.

So the midges crawl about within in durance vile, and keep increasing in numbers as new visitors arrive. Meanwhile, however, the lower female flowers arrive at maturity, and the top of each carpel or ovary develops a sticky stigma. Amongst these gummy surfaces the tiny flies wander in search of the nectar which they need 


\section{THE COMMON ARUM}

and which they cannot find, and from their legs and bodies are rubbed most, if not all, of the pollen grains they brought with them from the arums they previously visited. And here lies the essence of the whole scheme. Each carpel in this manner gets cross-fertilised with pollen from a neighbouring plant. Of course, the arum will eventually develop pollen of its own, but, as we have said, cross-fertilisation results in stronger offspring than those produced by self-fertilisation, and so the plant lays itself out to effect that end.

After a time when every ovary is fertilised, the stigmas begin to shrivel and dry, and the hungry insects, now almost on the point of starvation, at last get their reward. Each carpel now secretes a drop of nectar, and the thirsty midges greedily drink it up as fast as it appears. This nectar, however, is very strong, and after partaking of it, the midges are gradually overcome and fall helpless into the lower part of the floral chamber. Yellow pollen then begins to shower down upon them, for the male flowers are now arriving at maturity. This pollen cannot, however, influence the stigmas of the female flowers, for these have now lost their sensitive nature. So there the intoxicated insects lie in heaps as the pollen continues to fall upon them, indeed, they are literally buried under it.

There comes a time of respite, however, later, when the flies begin to revive and feel that they have had about enough of it and to realise that a little fresh air would be an excellent tonic. 


\section{LIFE HISTORIES OF FAMILIAR PLANTS}

So, covered with pollen, they ascend the central axis preparatory to leaving the bloom. The barrier bristles now no longer stop the way, for the plant has no further use for the insects' company; they have done their work, and received their due payment, therefore they are now allowed their liberty. So on reaching the purple club the insect pushes off it into space. The air, together with the insect's flight, refreshes it wonderfully, so much so that probably before it has travelled many yards it becomes fascinated by a most charming purple club standing out fresh and cool against an enfolding pale-green sheath. Thus it is enticed once more into another arum bloom to be prisoner for a few days; and while there, it will have plenty of time to clean its pollen-laden limbs and rub the grains about the sticky stigmas of the flowers within. Thus the whole process is once more repeated.

In Fig. 30 (Plate 20) is shown a magnified view of the wings of a midge taken from an arum that had yet to shed its pollen, and the numerous tiny grains (brought from a previous bloom) adhering to its wings should be observed. Also, it should be remembered that only one of these microscopic grains is needed on the stigma to effect the fertilisation of the ovary of each female flower.

Before our present-day knowledge of the relationship between insects and flowers, the fact that the male flowers are arranged above the female and shower down pollen upon them would have been held sufficient to show how perfectly 
PLATE 20
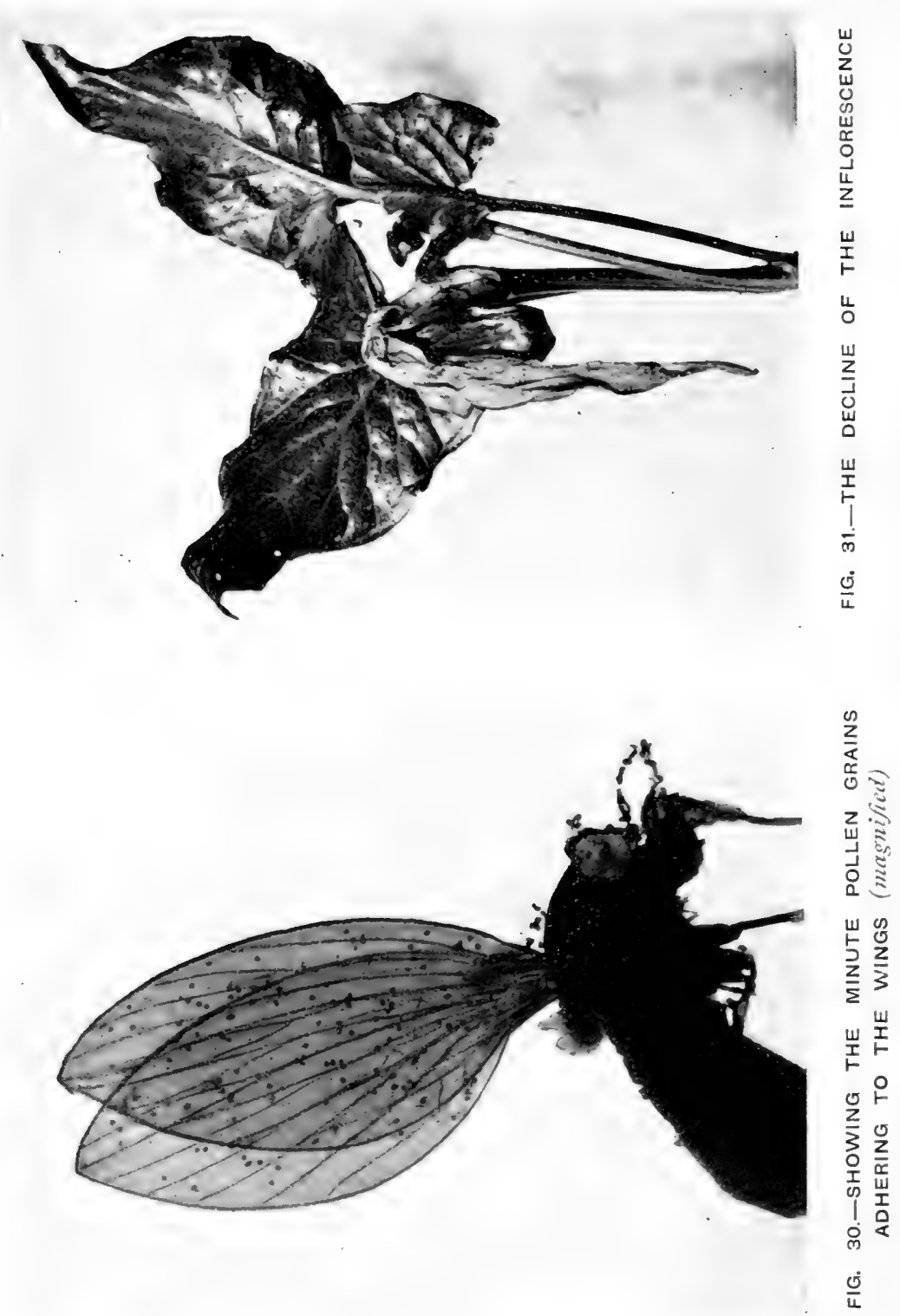

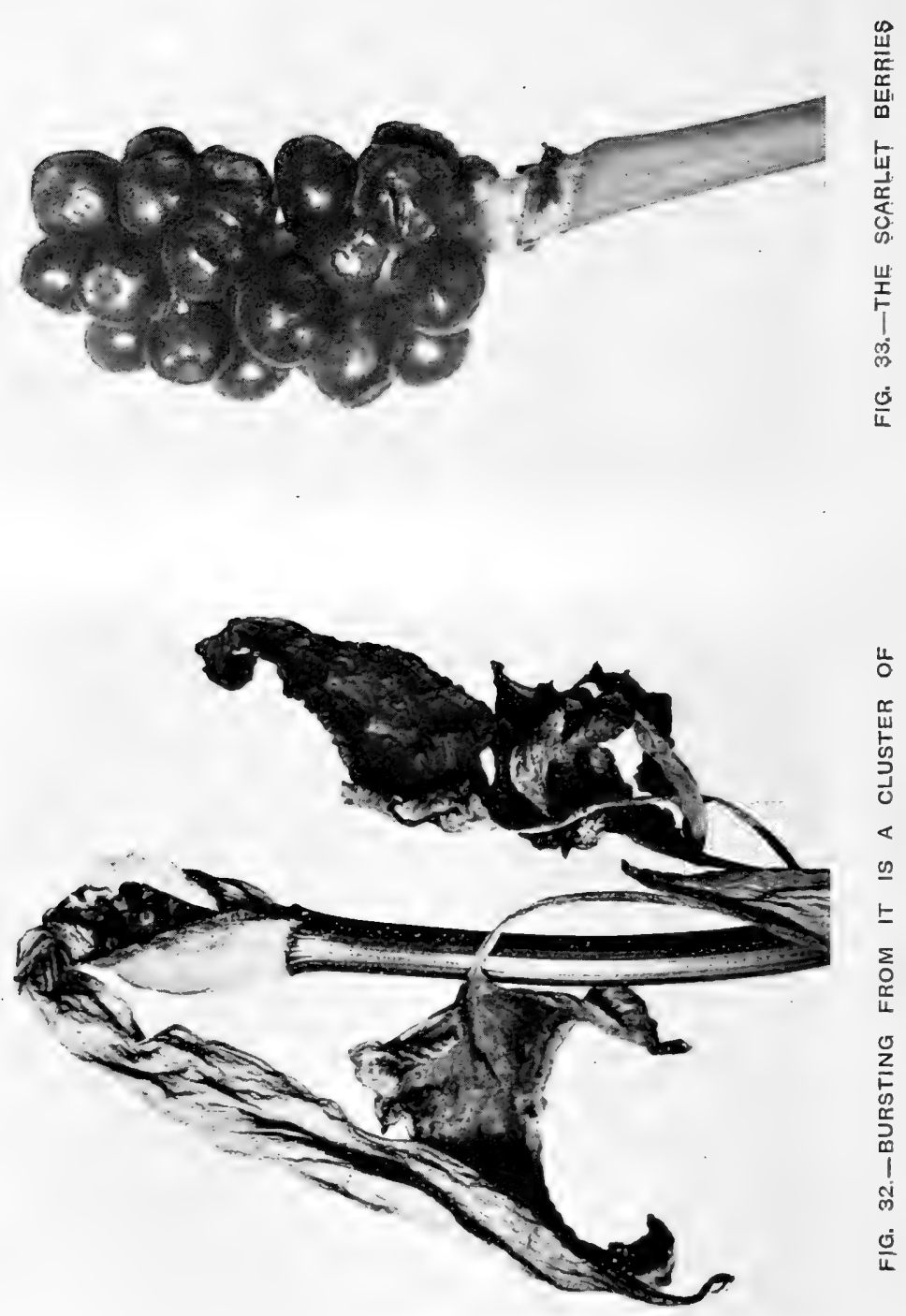

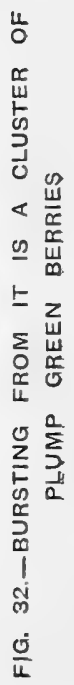




\section{THE COMMON ARUM}

arranged they were for pollination; but the appearance of the insects, followed by the secretion of the nectar, and the fact that the female flowers mature before the pollen of the male flowers above them is ripe, compel quite a different explanation.

The arrangement of the floral parts, combined with their orderly and systematic working in connection with the insects that visit the bloom, then, are surely sufficient proof that their true function has here been described. If, though, further proof be needed, we have only to watch the subsequent development of this singular inflorescence.

After the midges have departed with their loads of pollen, no more insect visitors arrive. In fact, the plant at once begins to take in the signpost. In Fig. 27 (Plate I8) we see the arum as it appeared on May I 9 th, but if we look at Fig. 3I (Plate 20), as it appeared on June 8th, we see that its aspect has changed very much. Not even the most giddy of midge-flies would ever attempt to visit an arum as it appears in the latter illustration. The purple club has shrivelled away and turned down right to the base of the group of male flowers, and likewise the hood that gave the club such prominence, also now cuts a sorry figure. Indeed, at first, you might think that the whole thing was dead. The leaves, however, are still working to build up this central structure.

In Fig. 32 (Plate 2I) we see it as it appeared on August 2oth. There it will be seen that the turn of the leaves to shrivel had arrived, for they had 


\section{LIFE HISTORIES OF FAMILIAR PLANTS}

done their work, and the memorial of that work was conspicuous enough. The shrivelled hood is seen still clinging to the structure, but bursting from it is a cluster of plump, green berries, which immediately they become exposed to the light turn a bright scarlet colour. And so the hood falls away and exposes the berries, which stand on their stout stem looking a most conspicuous patch of brilliant red (Fig. 33, Plate 21). Why this bold front, though? Has the arum some other scheme on hand?

Yes, the arum needs service from the animal world. Many plants not only bribe insects to assist in fertilising their flowers, but also induce larger creatures to disseminate their seeds. The method adopted is generally that of a juicy sweet pulp around the hard seed, so that an animal shall carry off the fruit and cast away the stone, or seed, in distant places where it may germinate. In the case of the arum we have this principle carried out exactly. Each of those tiny carpels of the female flowers pollinated by the pollen brought by the visiting midges, has now become a red, juicy berry containing a hard seed, and this bright berry boldly invites animals to feast upon it. But we find that the berries are extremely poisonous, and thereupon the whole theory is apparently self-contradictory. The fruit is made attractive and inviting to tempt the appetite, but then it is made poisonous to prevent it from being eaten. Surely there is something amiss here !

We have to remember, though, the fact that 


\section{THE COMMON ARUM}

birds are so constituted that what is poisonous to man and other animals is not always so to them. Thrushes, for example, devour the arum berries with impunity, but at the same time there are many smaller birds, such as robins, and large animals, not to mention man, to whom these same berries would probably prove fatal. Most likely the fact is that the arum specially caters for birds of the thrush class that consume its fruits and convey its seeds far and wide, and not for nibbling animals, such as mice and squirrels, which might do the seeds an injury. As the plant has slowly evolved those poisonous properties which prevent undesirable animals from munching its seeds, the thrushes, which best serve the purpose of distribution, have kept even pace in the development of a power to resist the poison; like confirmed opium-eaters, they may now safely consume quantities of poison that would mean death to others.

Let us suppose, however, that a small animal or bird should eat such berries and thereby lose its life. The plant would then gain at the expense of the animal, for the decaying remains would offer advantages to the developing plant after the seed had germinated. By the law of heredity, too, the succeeding generation of arums, on account of this advantage, would develop still stronger poison in their berries, which would be still more attractive in appearance.

Such, then, is the brief history of a very common British plant, and a common plant 


\section{LIFE HISTORIES OF FAMILIAR PI.ANTS}

necessarily means a successful plant, one that has held its own in the struggle for existence. Its success, however, is the just reward of its originality, for Nature is always willing to help an organism that strikes out a successful line of development. And even if the arum's success means the occasional death of a small animal, it does not matter in the least, for a successful plant is more to Nature than a foolish animal that cannot distinguish between proper and improper food material, for that animal can be of no service to its race, so Nature helps the race by briefly terminating the career of this faulty individual. Thus Nature's apparent cruelty is really both wise and kind, for the race of animals benefits as well as the arum plant. 


\section{CHAPTER IV}

\section{CATKINS}

AT the end of January, long before the leaf buds wake up from their winter sleep, the hedgerows and woodlands are once again producing those quaint, floral structures known as "catkins." Throughout February, March, and well into April their variety increases, one species of tree after another putting forth its blossoms. Many people quite overlook the fact that our forest trees all bear flowers ; in fact it may be said that all British plants produce flowers, excepting ferns and mosses and still lower forms that we need not consider. Probably some of my readers will feel certain that they have seen trees and plants which never produce flowers, but that conviction would only prove that either they have failed to notice the flowers in their proper season, or that the plant has failed to flower solely from lack of proper cultivation.

Many of these plants whose flowers appear and are almost unnoticed at the time produce fruits or seeds that are familiar to most persons. Now the mere fact of gathering a nut, berry, or a juicy fruit from a tree is conclusive evidence that it has previously flowered, for the fruit is the product of the flower. We find striking examples 


\section{LIFE HISTORIES OF FAMILIAR PLANTS}

of this amongst familiar trees. Comparatively few people are acquainted with the flowers of the oak, elm, beech, and hazel trees ; yet the acorns of the oak, the winged seeds of the elm (Fig. 43, Plate 27), the beech-nuts and also the hazel-nuts (Fig. 37 , Plate 24) are perfectly familiar to them when they appear.

This unfamiliarity with tree flowers is easy to explain. These flowers develop their parts during early spring, mostly before the leaves appear, when the trees themselves are not very readily distinguished by the ordinary untrained eye. Then, again, the flowers of trees are generally catkins, which all, more or less, resemble each other, and, consequently, are not readily recognised as different species. The hazel catkins of the hedgerows and woodlands (Fig. 34, Plate 23) are the first to make their appearance, and are doubtless the most familiar of this kind of blossom. There is, however, a common error with regard to these catkins. The long, pendent blossoms are often said to develop into hedge-nuts. That this is quite wrong may be readily proved by observing that, when the leaves begin to appear, the catkins drop from the branches just as the leaves do in autumn. Nevertheless, these catkins have performed their functions, and without them there could certainly be no hedge-nuts.

If on a still day you suddenly strike a branch of a hazel tree bearing catkins, you will immediately observe a cloud of yellow dust issuing from the catkins. By studying Fig. 34 (Plate 23), 


\section{CATKINS}

the catkins will be seen to be composed of numerous scales which stand out horizontally from the central axis. Each of these scales covers eight tiny stamens which produce the yellow fertilising dust that falls so readily from the blossoms. It should be observed that the scales are arranged in spiral fashion about the pendent stalk; the average number of scales on each catkin is about I60, so that each catkin bears about this number of little flowers; for each scale with its eight stamens is a flower. The catkin is, therefore, a little pendent spike of flowers; and these flowers are all male flowers, for they consist of stamens covered with a protective scale. In such flowers as poppies and lilies both stamens and ovary are found together with coloured petals in one flower, which make such flowers both male and female, but here we have an altogether different arrangement, for these catkins conduct their floral diplomacy on principles quite unlike those adopted by flowers that woo insects with attractive colours and sweet nectar.

It is obvious that these catkins of male flowers can never produce seeds like those of the lily or poppy, for they have no ovary ; and, as I have previously stated, they drop from the trees after the stamens have shed their pollen. We have, therefore, to search elsewhere for the female flowers, i.e., the flowers that eventually become hedge-nuts.

Glancing along the branches that bear the catkins, you will find here and there a bud with E 


\section{LIFE HISTORIES OF FAMILIAR PLANTS}

some crimson filaments protruding from its apex (two examples can be seen in Fig. 34, Plate 23), and it is these buds which contain the female flowers, together with the future hazel-nuts. These female blossoms are crowded together within the bud-like catkin, a scale placed between each two of the tiny ovaries, the outer scales of the catkin being empty. From the summit of each ovary spring two crimson stigmas, each pair, therefore, representing one female flower within. The female catkin, then, like the larger male catkins, contains numerous flowers.

Now, having mastered the technicalities of structural detail, we may proceed to discover why the hazel has developed these curious catkins of colourless, insignificant-looking flowers; and also why the females and males need different forms of catkin. There are, I think, although probably all botanists will not agree with me, good reasons for thinking that these catkins of the woodland trees were at one time more handsome flowers, and that their remote ancestors may have wooed insects with attractive colours and sweet nectar. All that, however, has passed away; they can now afford to ignore the services of their insect allies.

Sometimes a clumsy bee is seen struggling with one of these catkins, because it has discovered that it can make use of the pollen, which so early in the year is valuable: but no nectar is provided, and to climb a dangling catkin is anything but comfortable; therefore, when better and more profitable flowers begin to appear, catkins are left 


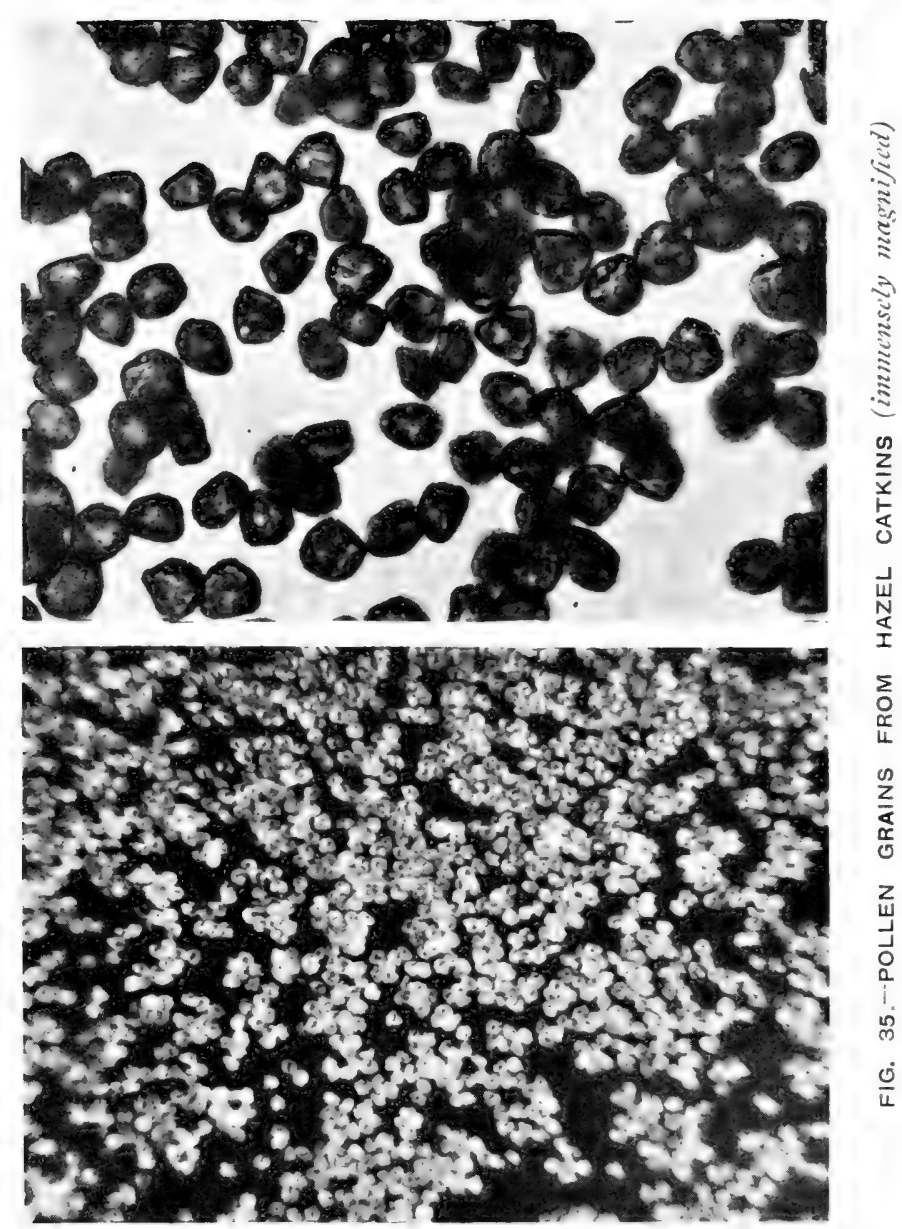





\section{CATKINS}

severely alone. To the catkins themselves the visit of the bee is generally a sheer loss, for the bee does not visit the female catkins and convey the fertilising pollen to their stigmas, but, instead, carries quantities of the pollen away for its own purposes. Besides that, the bee wastes much of the pollen by so clumsily shaking it from the catkins, causing it to be distributed where it will effect no useful purpose. The bee is in the wrong place; the catkins have changed their love, they no longer woo insects, but the wind.

There is the secret of the whole matter. Rich nectar, coloured petals, sweet perfumes, convenient landing stages, with sign-posts such as rows of hairs, coloured lines and spots all converging to the nectary of the flowers, are all absent in the flowers of the catkins, because the wind does not require these inducements. Instead of them we have rows of horizontal scales with hollow cavities in their backs all arranged one above the other, and beneath them stamens that are continually ripening and shedding their pollen, which falls from them into the hollowed backs of the scales immediately below them, accumulating there into little heaps.

In this way, when the atmosphere is still, the catkin becomes, as it were, a row of little shelves all loaded up with pollen. Then comes a gentle puff of wind that vibrates the catkin, and from its scales arise little clouds of dust. Then a larger gust shakes the branches and quite a shower of the golden dust rains down from the numerous catkins, 


\section{LIFE HISTORIES OF FAMILIAR PLANTS}

floating in the atmosphere like a cloud of smoke. After this comes a pause, and the little shelves once more begin to accumulate their loads of pollen; the ends of the catkins go on lengthening out and new scales are spread, and new stamens ripen.

How beautifully adapted is the structure of the catkin for the action of the wind! The complex arrangements of the insect-pollinated flowers are marvellous indeed, but this mechanism for windpollination is none the less wonderful in spite of its simplicity.

The pollen grains that float away so readily are so small and light that they often travel for miles even when borne by gentle winds. A microscopic examination of the branches and bark of trees during early spring will often reveal innumerable pollen grains adhering to them on the sides that have faced the wind, even when the trees are not bearing catkins themselves and are growing at some distance from those that do. This is especially noticeable when the wind arises after rain, and the bark and branches are moist and therefore retain the pollen grains.

Indeed, pollen has sometimes been blown from forests to distant towns and there accumulated about puddles and over the surface of the ground, where it has been mistaken for a fall of sulphur and looked upon as a portent of coming evils, until the botanist, by aid of his microscope, has revealed its true nature. It follows, therefore, that the grains of pollen must be exceedingly minute. How minute they really are Fig. 35 (Plate 22) will 


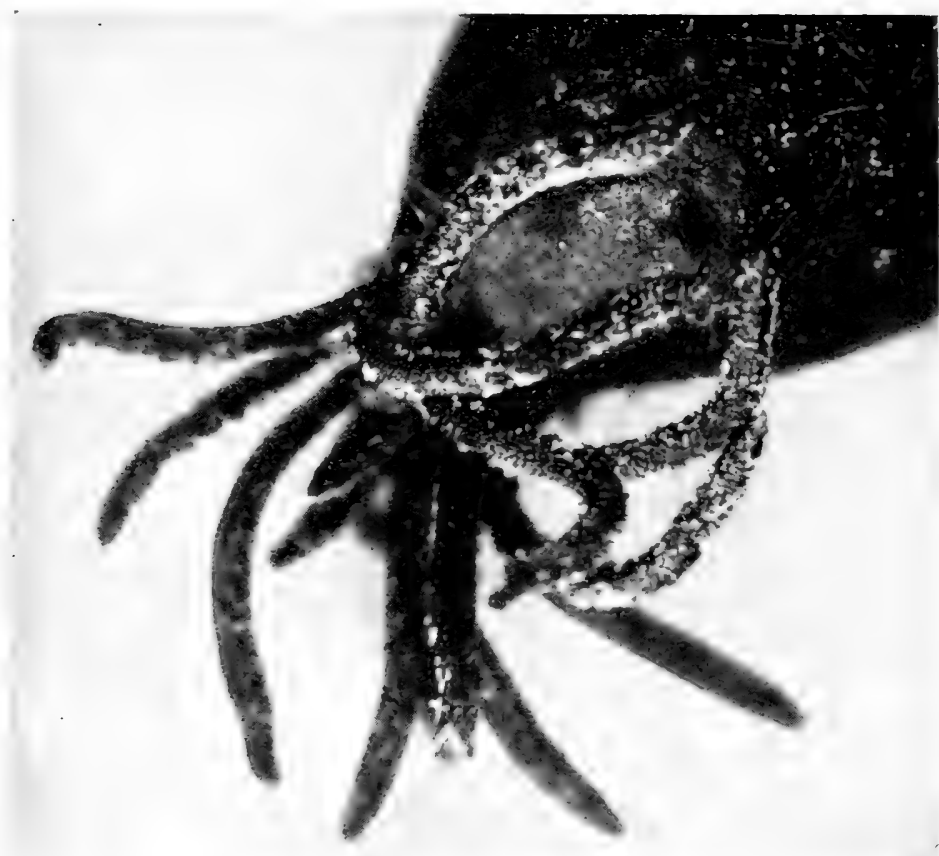

年

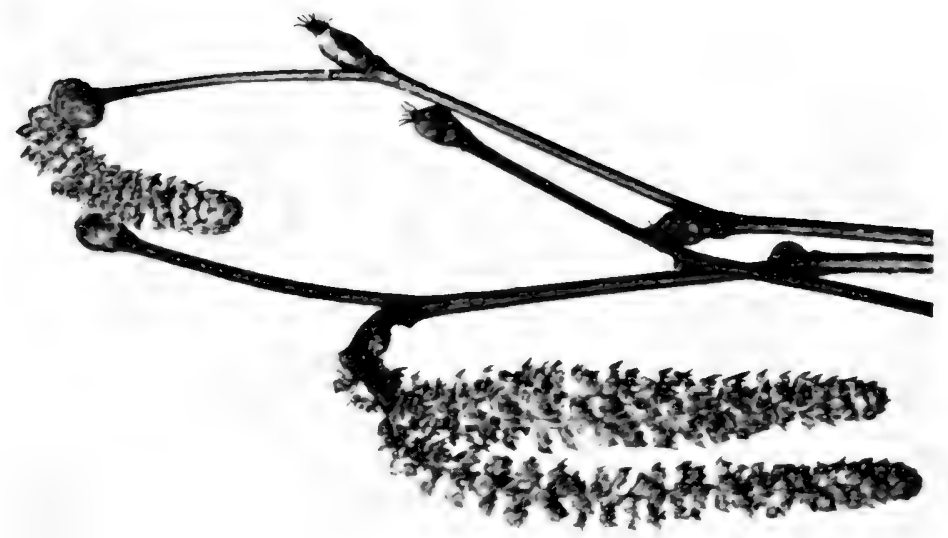

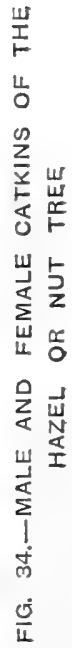



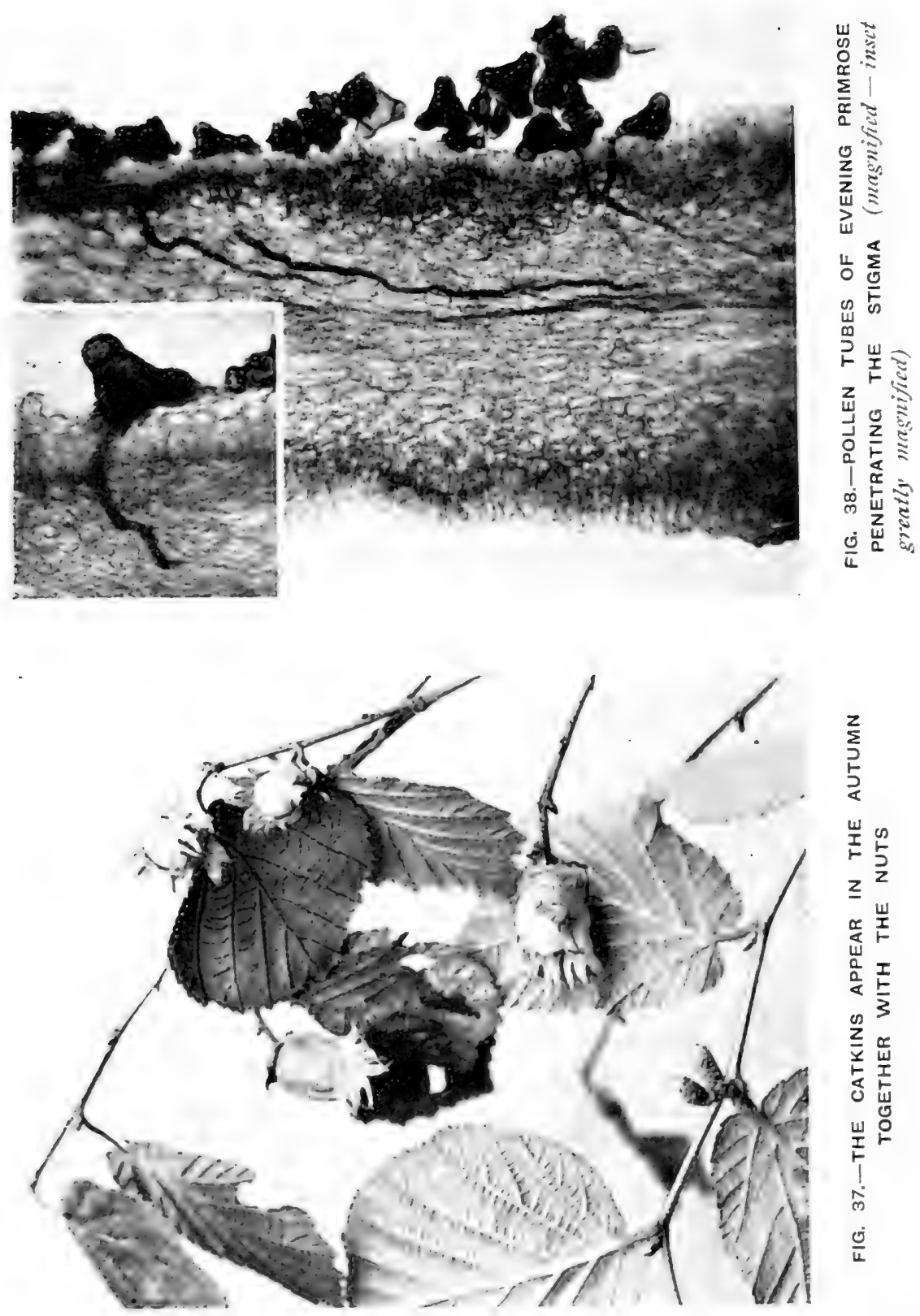

2
5
5
5

I

$z^{z}$

崖

嵌

\&

os $\overline{3}$

$\underline{z} \frac{c}{4}$

贞

迹

딴

$F$

西

in

U⿺ 


\section{CATKINS}

help to make clear. The pollen grains are there shown, to the left, magnified I0o diameters; or to put it more simply, they there appear 10,000 times as large as they really are. Again, on the right, some of the grains are shown magnified 300 diameters, or 90,000 times their actual size.

Having seen, then, how extremely tiny is each of these pollen grains, we are better able to realise that, when we shake the bough of the hazel bush and cause a yellow cloud of pollen to be dispersed, the cloud does not consist merely of thousands of pollen grains, but of many millions.

In view of this, it is not surprising that the rosy stigmas protruding from the female, bud-like catkins should receive some of the pollen from the atmosphere. I have selected at random from a hazel branch one of these catkins, taking care while gathering it not to shake upon it any pollen from the catkins on the same branch. In Fig. 36 (Plate 23) a magnified view of this catkin is shown, and it is particularly interesting owing to the fact that the pollen seems to have adhered to the stigma only on the sides that face in one direction; and the side of the catkin itself that faces the same way is also dotted over with the tiny, pale-yellow grains. These details, together with the fact that the grains are thinly scattered, all point to the conclusion that the pollen visible had slowly accumulated from a given direction; most probably carried by the wind or, it may be, by falling showers in regular succession from the catkins of the branches near by. 


\section{LIFE HISTORIES OF FAMILIAR PLANTS}

Thus the hazel gets its stigmas pollinated without producing colours, sweets, perfumes, or any other devices that will attract insects and cause them to convey the fertilising pollen from bloom to bloom. Of course, in spite of the vast quantities of pollen produced, insect-fertilisation is much the surer method, for an insect flies from flower to flower as it sees them, whereas pollination by the wind is purely a matter of chance. Probably this accounts for the fact that so many of the seeds of the crimson-tipped catkins never ripen. Even the catkins that do mature rarely produce more than two or three seeds, although they often contain nine or ten female flowers. And this is the reason why we find hedge-nuts singly or clustered in twos and threes, according to the product of the catkin (Fig. 37, Plate 24).

What is the use of the crimson stigmas, if colour is of no service to the catkins? This is a question that may naturally be asked. The answer is that, crimson and purple browns are great attractors of heat rays, and during the early months of the year the weak rays of sunlight have to be made much of. If the male catkins are noticed before they lengthen out, they will also be seen to be of a reddish-brown colour, the colour being concentrated on the side that meets the sunlight. Therefore, the crimson filaments of the stigmas attract warmth and stimulate the pollen to carry out the function of fertilisation.

The tiny pollen grain seems almost too minute to be heeded, and yet what marvels it performs 


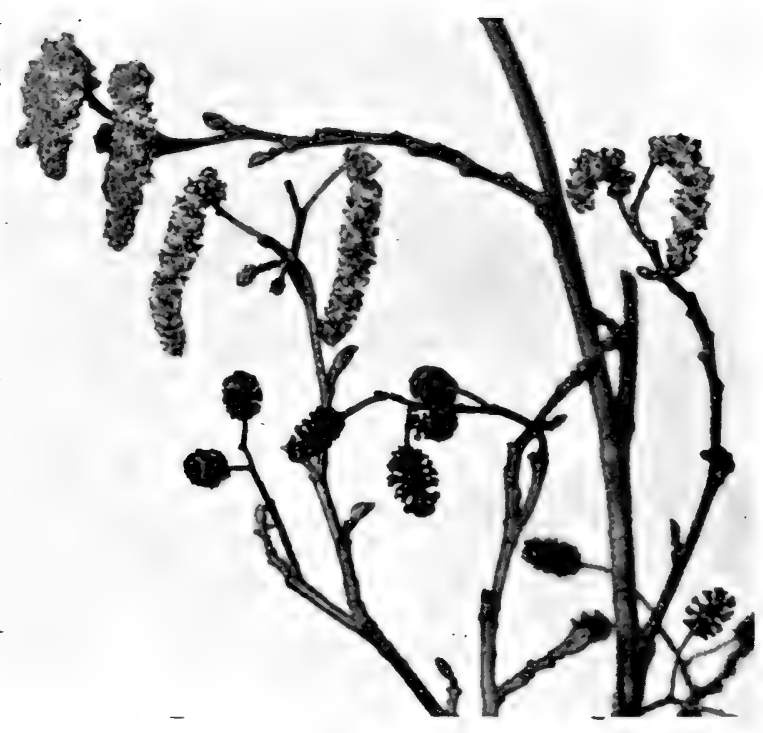

FIG. 39.-ALDER CATKINS

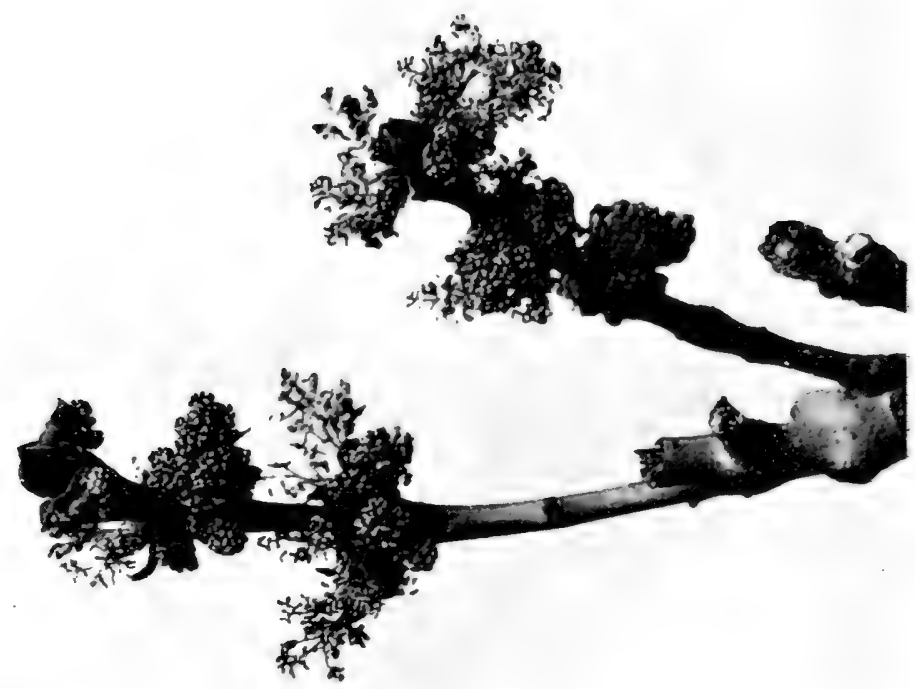

FIG. 40.-FLOWERS OF THE ASH TREE 
PLATE 26
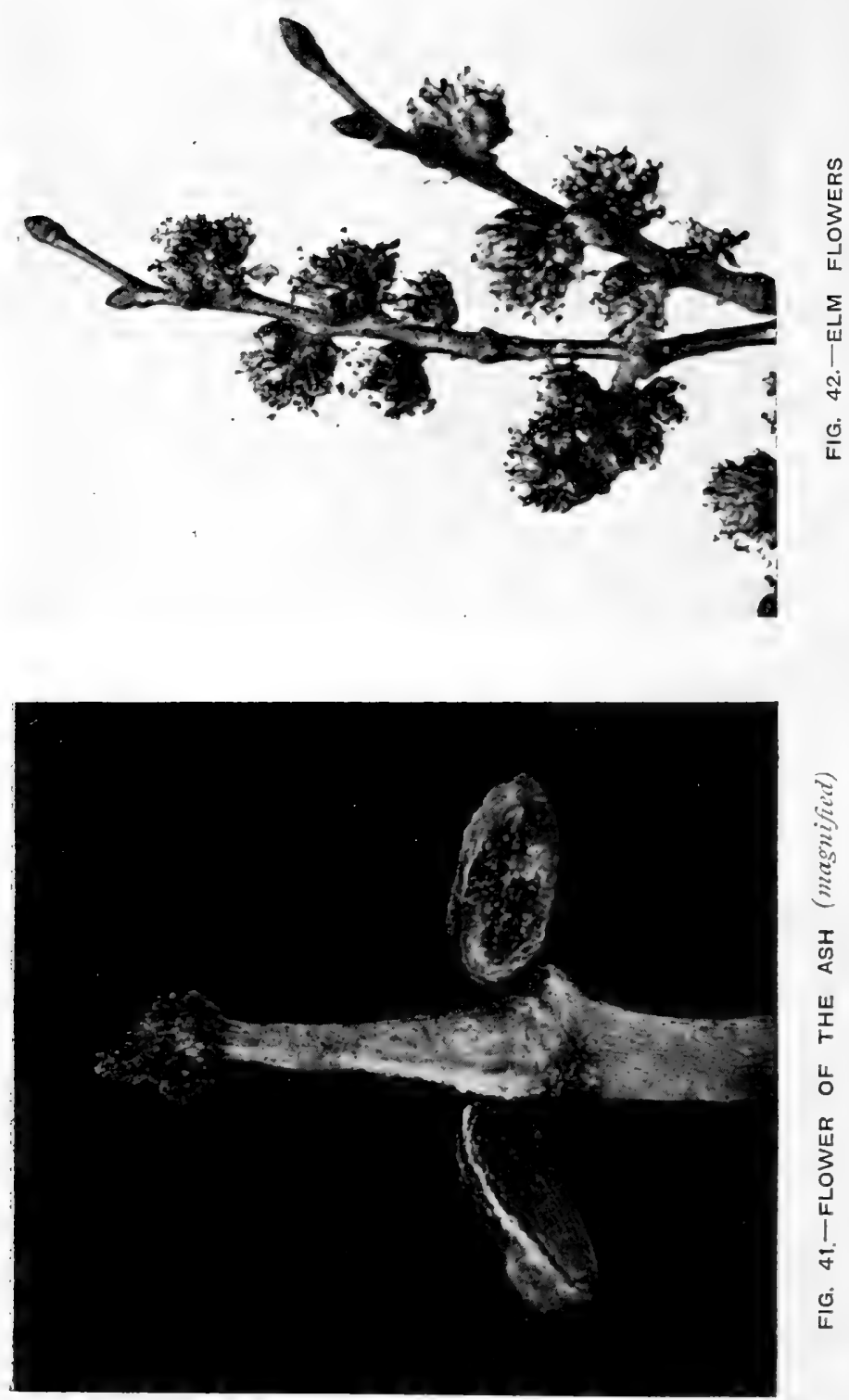

व 


\section{CATKINS}

after reaching the stigma. A kind of germination takes place, and the little grain develops a delicate tube which penetrates the tissues of the stigma. This tube travels right away to the embryo seed within the heart of the catkin, the fertilising element of the grain being thus conveyed to the future seed, which afterwards rapidly develops. A glance at Fig. 36 (Plate 23) will show that the extremely minute pollen grain must extend a tube many hundreds of times longer than its diameter to reach the embryo seed within the catkin. In Fig. 38 (Plate 24) is shown a section of the stigma of a flower of the evening primrose, to show how pollen tubes penetrate the tissues of the stigma. This example is used for illustration because the pollen grains and tissues of the evening primrose are larger and more suitable for photographic purposes. However, the movements of the pollen tubes through the stigmas of the hazel catkins are practically the same.

In the previous chapters I have called attention to the devices which insect-pollinated flowers employ to effect cross-pollination, by means of which stronger and better seeds are produced. The hazel attains that end by producing its male and female flowers in separate catkins; and as the male catkins are pendulous, while the female are held upright, the latter are much more likely to receive pollen blown from other quarters than from their immediate neighbours.

Having thus dealt in detail with the hazel, my reader will now be able to investigate, on his own 


\section{LIFE HISTORIES OF FAMILIAR PLANTS}

account, other catkin-bearing trees; for what I have written here regarding the hazel applies in a general way to others. However, in conclusion, I will just glance at one or two slightly different examples of tree flowers.

Near the river and in watery places we shall find the alder, whose male catkins are very like those of the hazel, but the female catkins form little cones of a red colour, which eventually develop into woody structures with seeds between their scales. The old woody cones may often be found together with the new on the same branches (Fig. 39, Plate 25).

Then there are the curious black buds that break out on the ends of the branches of the ash, revealing clusters of brownish flowers (Fig. 40, Plate 25). These flowers are very simple in structure, some being male and consisting only of a pair of stamens, others female, consisting only of a single ovary, while still others may possess both ovary and stamens, these last being, of course, both male and female. An enlarged photograph of one of these latter is shown in Fig. 4I (Plate 26). The three forms may sometimes be found upon the same tree, and each ovary develops into the winged seeds known as "keys" (Fig. 44, Plate 27).

Finally, we may consider the flowers of the elm. These grow at the summit of the branches and are often difficult to reach, although rooks when building will frequently throw down branches bearing good specimens. In Fig. 42 (Plate 26) some of these flowers are shown. They appear in $5^{6}$ 

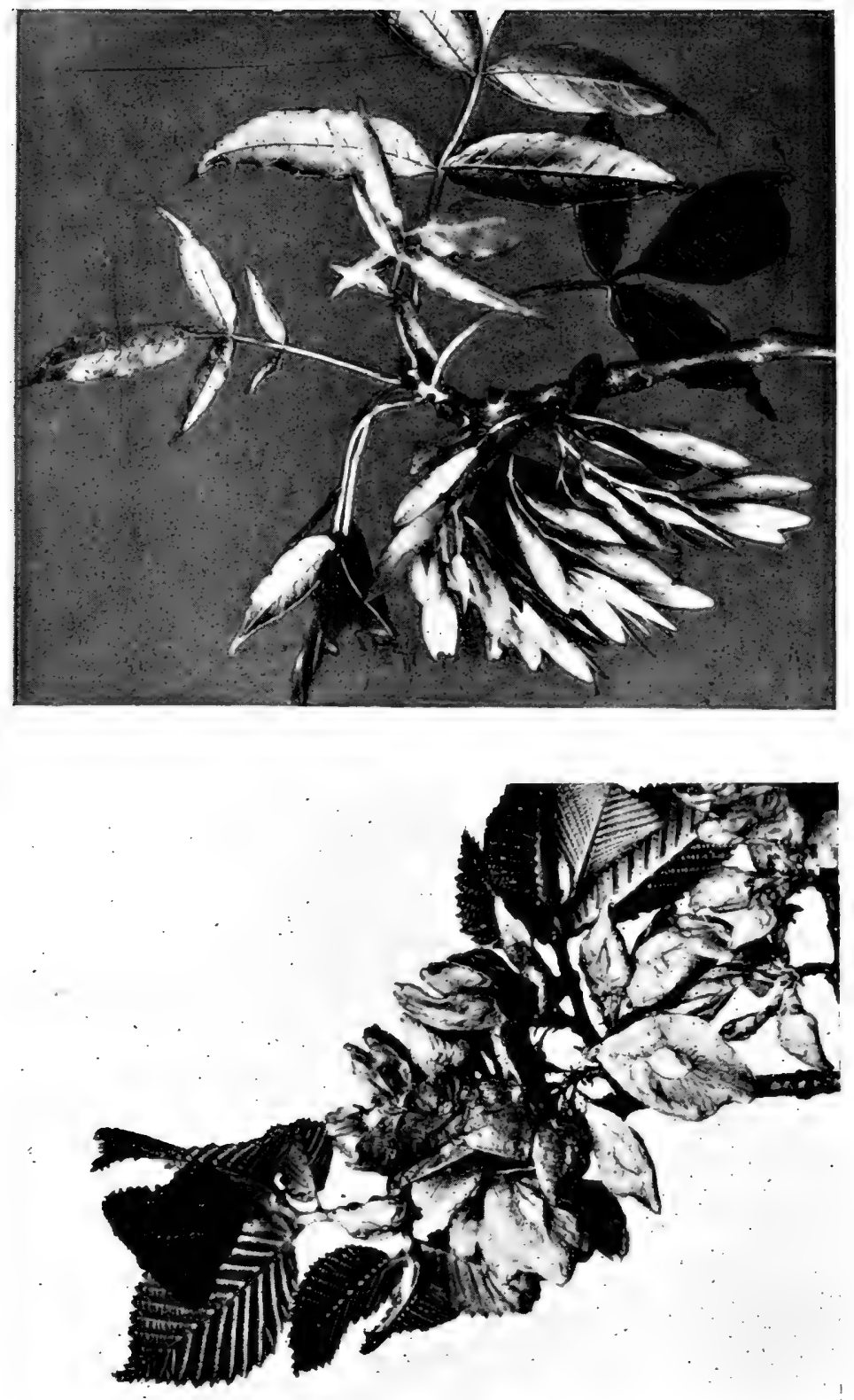
PLATE 28

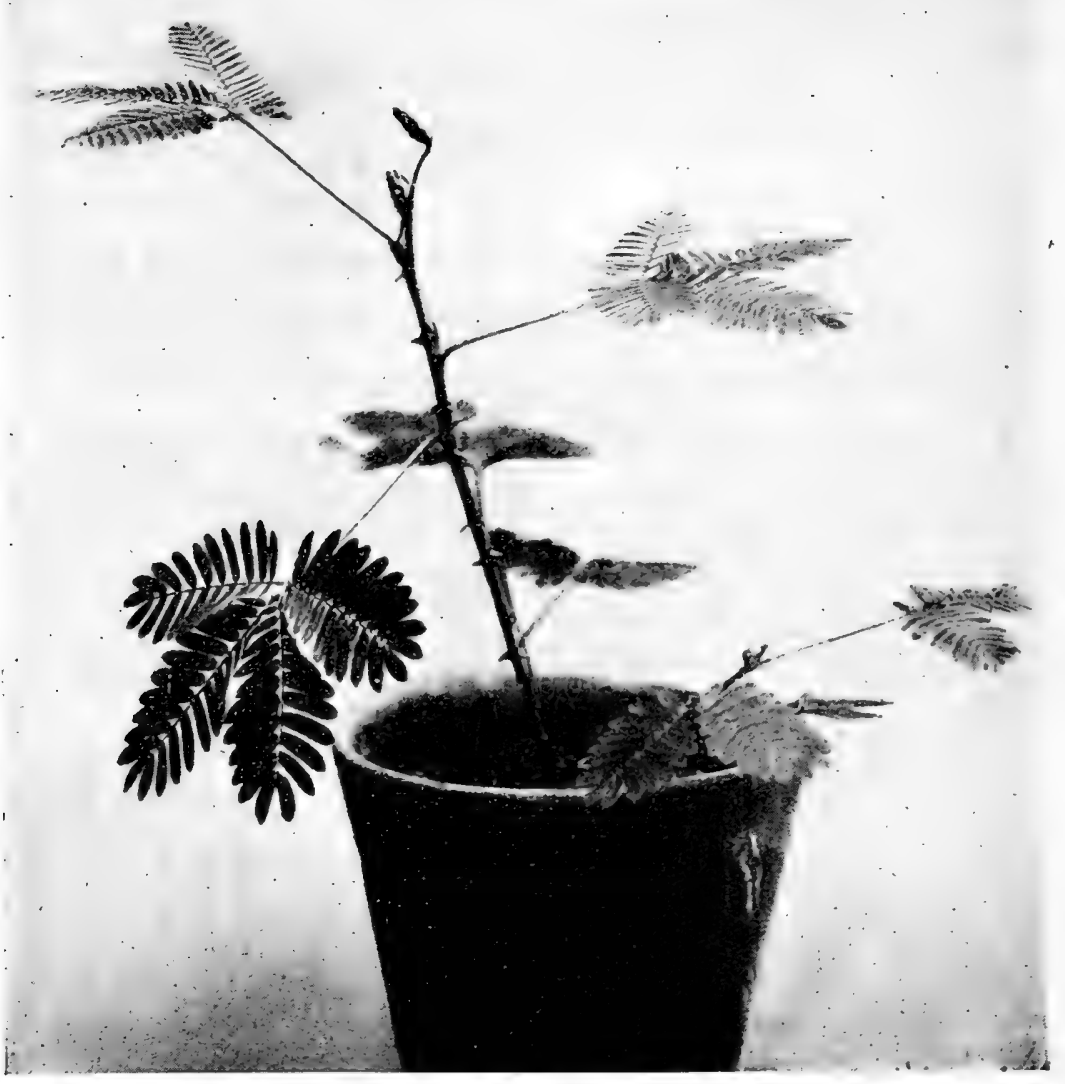

FIG. 45, - THE SENSITIVE PLANT WHEN CIRCUMSTANCES ARE FAVOURABLE BUT IF YOU BREATHE UPON IT- 


\section{CATKINS}

clusters, and each flower consists of an ovary surrounded by a brown cup-like envelope bearing six stamens; so that they more nearly approach such flowers as the lily and poppy previously referred to. Later, when the leaves appear, each of their ovaries develops into a leaf-like fruit with a thickened seed in the centre, the fruit being readily dispersed by its leafy attachment (Fig. 43, Plate 27).

There are many other examples that might be considered, such as oak, willow, beech, birch, hornbeam, etc., but these will all be found, more or less, to resemble those examples I have mentioned above; and the rambler in search of them may fathom their secrets in most cases by means of a sharp penknife and a pocket magnifying lens. And while he is so doing he may think not only of the wondrous details of Nature's minute work, but also how well-planned are her schemes. Glancing at the leafless branches he will ask: Why do not the catkins appear, like most other flowers, together with the leaves? Then let him reflect upon the agency of the thicket of leaves in intercepting the pollen carried here and there by the winds, and the answer is obvious. Then, again, March and April are the two months of the year when the catkins hold their revels; and also these months are the windiest of the year. The infinitely minute pollen grain, the "March winds," and the giant oak or elm tree are all simple links in a perfect chain of interrelated facts-another example of the perfect unity that underlies all Nature's processes. 


\section{CHAPTER V}

\section{SENSITIVE PLANTS}

ONE of the first caterpillars that we find in our gardens in the early spring is that of the familiar brown "woolly bear," the larva of the tiger moth. When we see this insect infant feeding on our plants, we only need to touch it with a finger to cause it immediately to become a hairy ball which at once drops to the ground. We may then try to pick it up from amongst the herbage below, but its long flexible hairs give way so readily to the touch, and are so often left in our fingers that not infrequently the caterpillar escapes by means of these defensive tactics; for leave it alone for a minute or two and it quickly unrolls its body and travels away at a surprising pace out of the danger zone.

There is nothing astonishing in the fact that the caterpillar thus shrinks at our touch. It is as natural as that a hedgehog which we might meet in the lane should assume the defensive and become a prickly ball when we poke it with our walking-stick. It is obvious to us, when we touch the hairs of the caterpillar or the spines of the hedgehog, that these creatures are sensible of the touch ; and it is apparent that the subsequent actions of both caterpillar and hedgehog are defensive. This sensitiveness, therefore, by prompting 


\section{SENSITIVE PLANTS}

them to take measures for their safety, serves a useful purpose in their struggle for existence. Instances of this kind are so familiar in animal life that we often fail to realise how very valuable to an animal is this delicate sense of touch. Indeed, this familiarity with the movements of animals is apt to make us oblivious even to their sensitiveness to external stimuli, and much more oblivious to their dependence on the possession of such sensibility for self-protection.

Turning now to plants, we should hardly expect to find developed in them the sense of touch, because we regard them as organisms without feeling. Also, we have to recognise that plants possess no nerves and brain centres such as we are familiar with in most animals. But, nevertheless, there are numerous plants which are just as sensitive as the caterpillar or hedgehog, or even more so. There are plants so sensitive that if, when standing by them, you should suddenly spread your umbrella or sunshade, it would be quite sufficient to cause them instantly to close together their leaflets and turn down their leaf stalks, just as if they were startled and alarmed by the movement. On a sunny day, when the temperature is sufficiently high, you need not make even so decided a movement; merely your shadow falling on their leaves will often cause them to droop slightly.

In Fig. 45 (Plate 28) is shown one of the most celebrated of these sensitive plants-Mimosa pudica, a native of Brazil-as it appears when 


\section{LIFE HISTORIES OF FAMILIAR PLANTS}

circumstances are favourable. Now I will ask you to look at Figs. 46, 47, and 48 (Plates 29, 30, and 3I); I may inform you that the movements exhibited from Fig. 45 to Fig. 48 occurred in about one second. The photograph, Fig. 45, having been taken, a slight breath of air through the lips was blown at the plant. The results depicted in Figs. 46, 47, and 48, therefore, were brought about entirely without touching the plant or even shaking the pot-simply by blowing upon it slightly.

Now, when upon our approach to a plant it suddenly folds up its leaves and assumes an altogether different attitude we very naturally ask, in wonder, why it acted so. Of course, in the case of our "woolly bear" caterpillar, and also our hedgehog, it was obvious that they derived protective advantages from their movements; but what practical use can this strange manœuvre of the sensitive plant serve in its economy?

Well, when a plant, without the slightest warning, closes together its leaflets and, as it were, "shuts up shop" in this summary fashion, we are naturally rather startled by the performance, and wonder what will happen next; and any grazing animal would have the same feeling. In tropical countries where such sensitive plants are found they frequently cover large tracts of land, and wandering, grazing animals come upon them; indeed, may be often attracted towards them by their bright green foliage. But what happens? The very first plants an animal approaches droop their tempting leaves, sensitive even to the 
PLATE 29

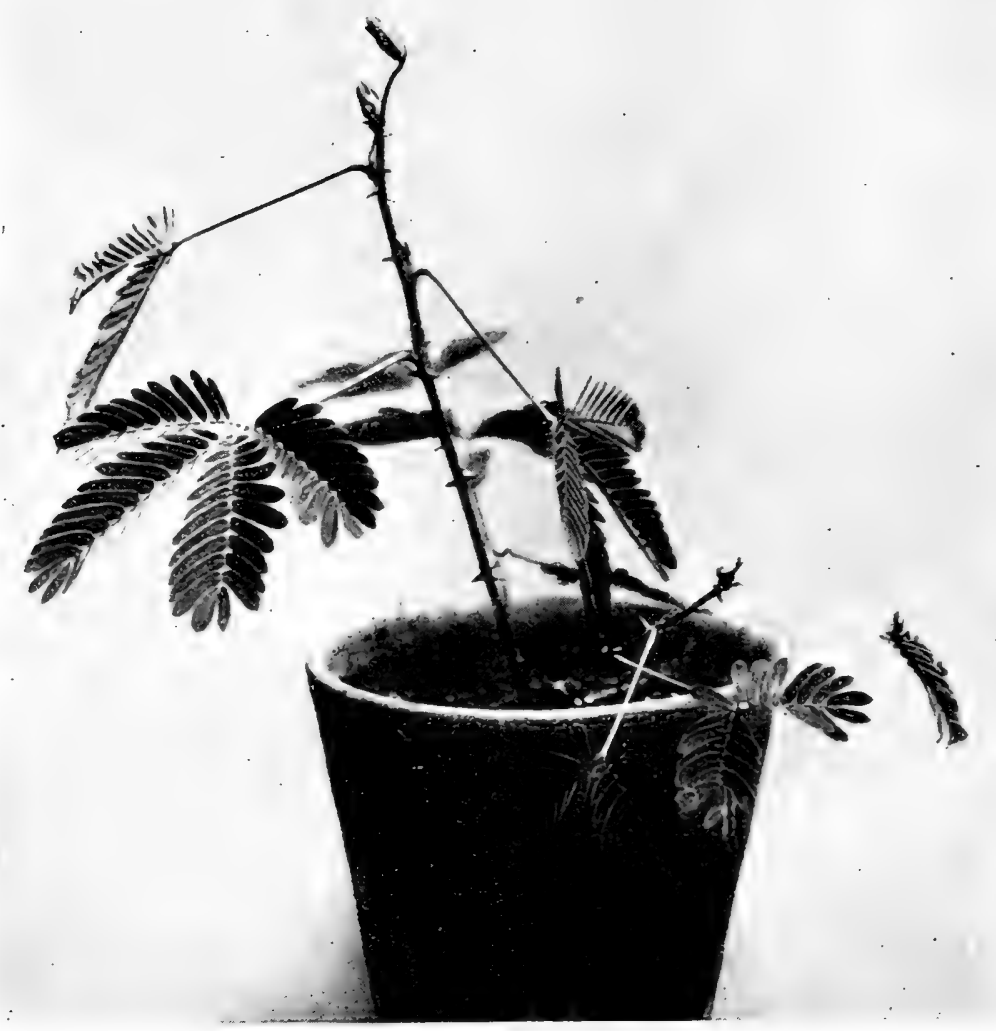

FIG. 46.-IT IMMEDIATELY CLOSES ITS LEAFLETS- 
PLATE 30

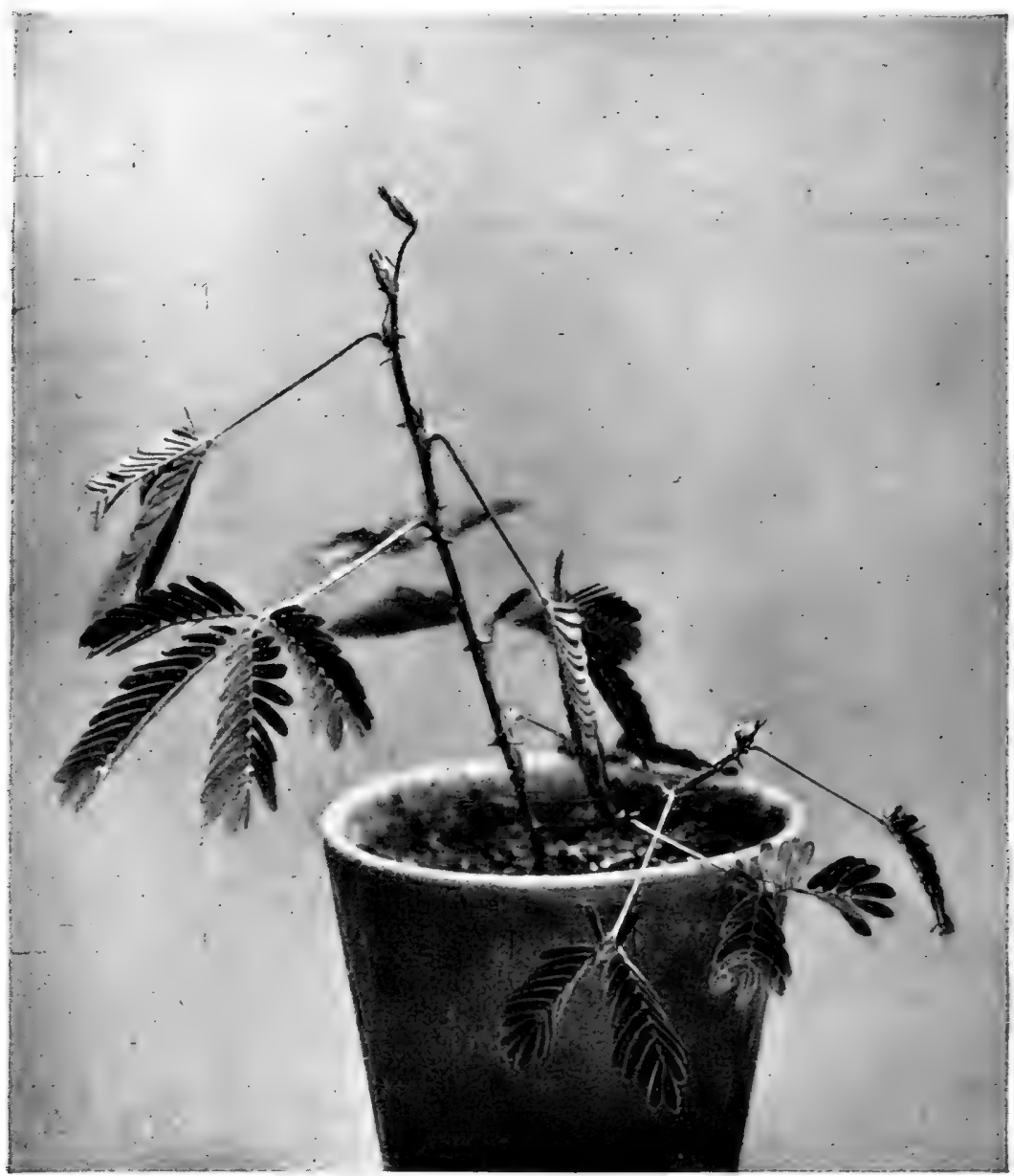

Fig. 47.-LETS falL its LEAF STALKS, and a SECOND LATER-- 


\section{SENSITIVE PLANTS}

vibration of the ground caused by its approach ; and should it step in amongst them, the tempting and juicy foliage shrinks before it, for one plant conveys the shock to its neighbours by the touch of its own leaves as they droop. Thus what was a moment before a mass of tempting green leaves becomes almost instantly in appearance very scrubby fare for the animal which anticipated much better refreshment.

Some readers may, perhaps, be inclined to doubt if the movements of these plants would protect them from the attacks of grazing animals, but it is interesting to observe that the stems of the example illustrated, and of many other species besides, are protected with strong and sharp spines. This feature alone shows that such plants have had to protect themselves against browsing animals; and now when they have turned down their leaves out of harm's way, they present to their enemy, for its first nibble, nothing but prickly stems; so that should the intruder not be awed by their uncanny movements, but proceed with its intention, its first mouthful would scarcely be agreeable after its richer anticipations.

Then, too, let us suppose that a hungry caterpillar climbs the stem of a sensitive plant and endeavours to feed upon its leaves. The caterpillar, of course, has to reach a leaf by its stalk, and in doing so it either gets thrown suddenly to the ground by the prompt drooping of the leaf, or, should it succeed in adhering, finds the succulent leaflets gathered in a tightly-closed bundle, most 6 I 


\section{LIFE HISTORIES OF FAMILIAR PLANTS}

difficult to move upon, let alone feed upon, while the whole arrangement is artfully contrived to conduct it towards the juicy end of this group of leaflets, which are now pointed towards the ground. However, when the caterpillar reaches this part, on which it would naturally begin its meal, the difficulties of feeding there, and the greater difficulty of climbing back up the slopinglyarranged leaflets, usually result in it dropping to the ground-probably more or less disgusted with sensitive plants and their absurd arrangements. Even should it hold to the stem of one plant and endeavour to feed upon the leaves of another, it is equally beaten, for the leaf it touches immediately shrinks from it and drops out of its reach.

It is clear, I think, that the sensitive plant, like the "woolly bear" and the hedgehog, gains some considerable protection in its struggle for existence by its sensitiveness. However, there is another question that arises when we consider the quaint movements of these plants. How did they first acquire these highly-evolved tactics which they now exercise with such conspicuous success against their natural foes? There must, of course, have been a beginning and then a gradual perfecting of the delicate sensitiveness they now exhibit. Apparently a difficult problem is presented when we seek to discover how this habit of shrinking from animal attacks was first acquired.

Before dealing with this point, however, I would ask my reader to glance at Fig. 49 (Plate 32). 
PLATE 31

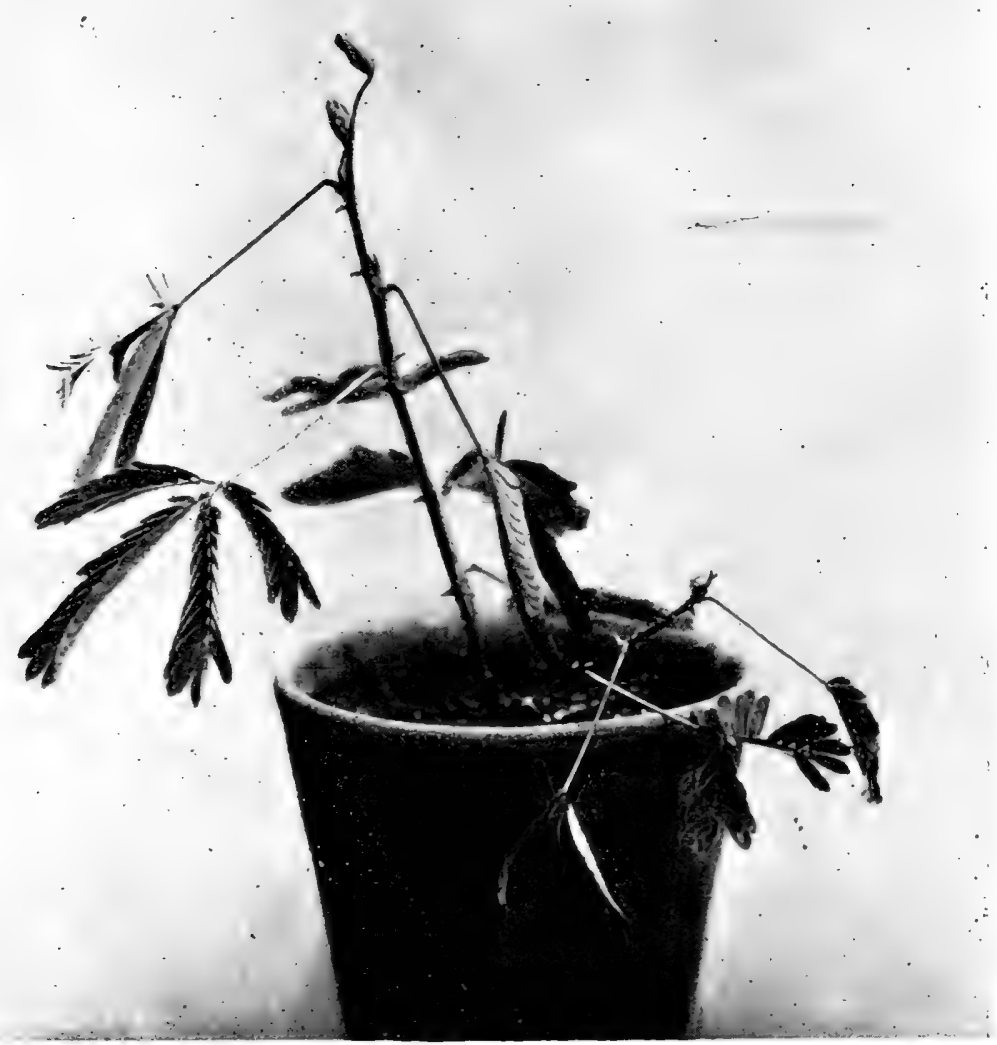

FIG. 48.-PRESENTS THIS APPEARANCE 


\section{PLATE 32}

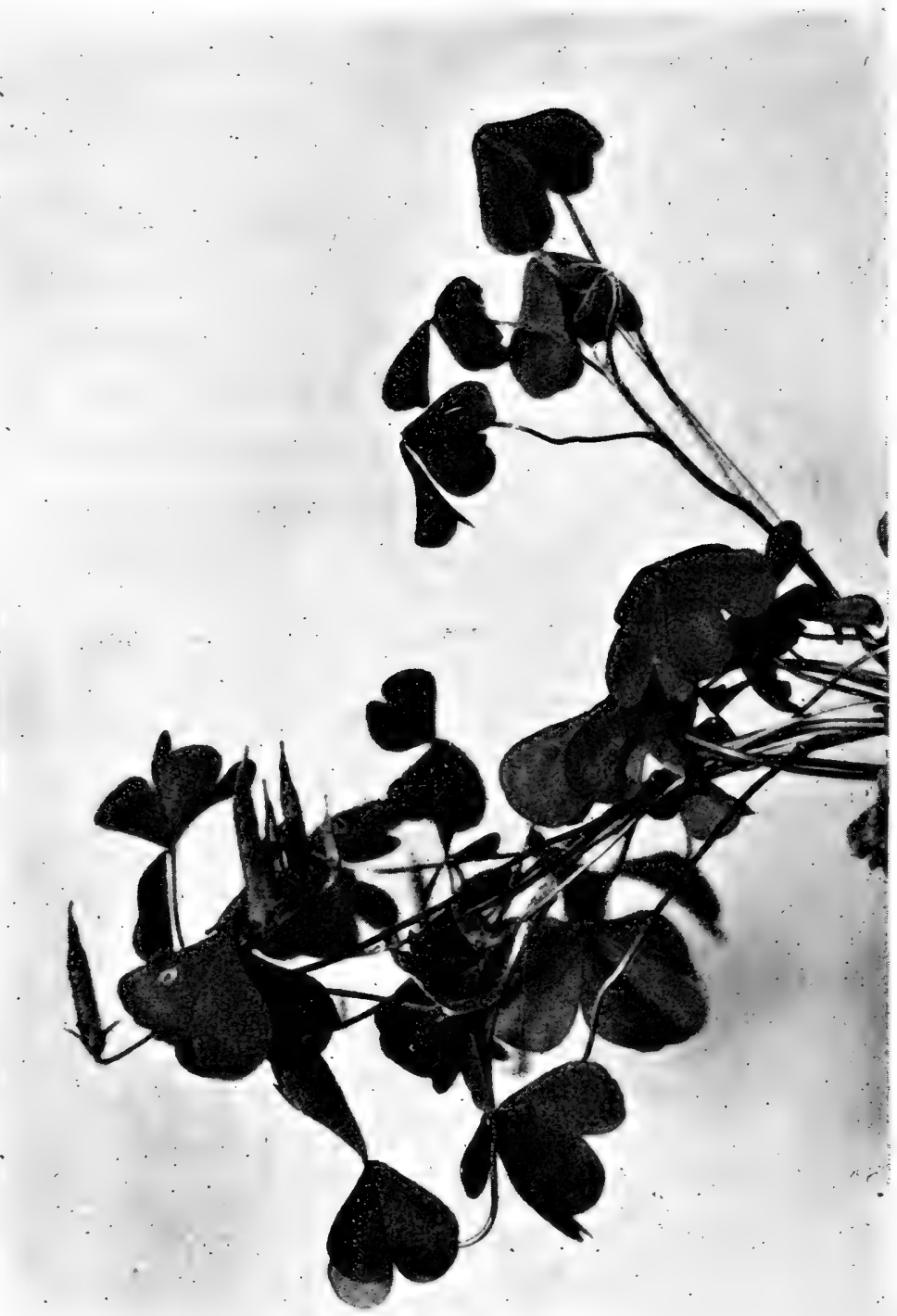

FIG. 49.-SPECIES OF OXALIS WITH LEAVES IN SLEEPING ATTITUDE 


\section{SENSITIVE PLANTS}

The photograph shows a cultivated species of oxalis, whose relative, the Common Woodsorrel (Oxalis acetosella), is familiar during early spring in woods almost everywhere in the British Isles. Its characteristic clover-like leaves (of a pleasant acid taste) and white purple-veined flowers readily distinguish it, The species shown here was photographed just before dusk, and it will be seen that the three leaflets of each leaf have turned down towards their stalks, and are now somewhat like partially closed umbrellas; later, when darkness comes, they will close still more, and become huddled together closely round their stalks. This same characteristic of drooping leaflets at night may also be observed in the common British wood-sorrel. When daylight appears the leaflets once more spread themselves out to the sunlight. It becomes quite apparent, therefore, that they have been to sleep, for each night the leaflets fold together, and each morning they open out again.

Here, then, we have the beginning of sensitiveness in leaves. The leaflets of the various species of oxalis are usually very thin and of frail texture, and their function is the same as that of the leaves of other plants, viz., to spread their tissues out to the sunlight, and under its influence to absorb gaseous food from the atmosphere. At night, when sunlight ceases, the leaves can no longer carry on their feeding process, for sunlight is essential.

Seeing, then, that the leaves serve no purpose 


\section{LIFE HISTORIES OF FAMILIAR PLANTS}

by being spread out at night-time, it is a very useful device on the part of the plant to close them together at nightfall; for then they are kept warm and their tissues are protected from the chilly night air. If the leaves were fully expanded, they would probably accumulate moisture, and at the slightest approach of cold or frost receive a chill which might cause them serious damage. However, with leaflets folded closely together, both in the case of the sensitive plant and the oxalis, rain drops and moisture are conducted to the earth below. So the first oxalis plant, which, in the natural variation of living things (for no two organisms, and no two habits in an organism, are identical) adopted the habit of drooping its leaves slightly when the temperature was lowered, found that it was beneficial, and it forthwith conveyed the hint to its race; and the habit, being good, it became hereditary. Thus the wood-sorrel, and others of its genus, acquired the habit of sleeping leaves; which, of course, represents sensitiveness to external conditions, such as light and temperature.

The species shown in Fig. 49 (Plate 32) has brown or copper-coloured foliage, and the leaves of the common wood-sorrel also often develop on their under sides this same reddish hue. This colouring matter, as I have previously pointed out, has the peculiar property of utilising the rays of light and converting their energy into heat, which naturally benefits the growing plant. For the same reason the buds of many plants, when they 


\section{SENSITIVE PLANTS}

develop in the spring (as the familiar hawthorn of the hedgerows) are red and brown. The coltsfoot which throws up its flower-bearing stems in February or March, well before its leaves, also clothes its flower stalks with reddish-coloured scales, and many other examples might be quoted where early growth takes place and, consequently, all the available heat of the sun's rays is needed.

This copper colour, then, is but another proof of the delicacy of the leaves of the Wood-sorrel family, and it is an additional indication of the sensitiveness of their leaflets and how much they need protection. A species that has evolved and developed a detail of this kind until every leaf has become a deep copper colour is, of course, a progressive one; in this species, too, the sleeping movement is much more readily induced than in the common British species. Furthermore, there are other species of oxalis which, with a little rough handling, will droop their leaflets in broad daylight; and in the Oxalis sensitiva, of India, we have another example of the same genus which has evolved its sensitiveness to almost the same stage as those of the Mimosas, or true sensitive plants, for its leaves contract at the slightest touch, just as shown in the figured representations of the sensitive plant. Also, we may note that amongst the Mimosas themselves all the species close their leaflets as night comes on; and amongst the various species we find exhibited every gradation of sensitiveness, just as we do in the Woodsorrel family. 


\section{LIFE HISTORIES OF FAMILIAR PLANTS}

Seeing that the Mimosas and the Wood-sorrel tribe are distinct groups of plants, their families being in no way related, it is, I think, reasonable to contend that the sensitive characteristic of their leaves was evolved from the sleeping habit. However, it still remains to explain how the plants acquired their habit of shrinking at the approach and the touch of animals.

The explanation is very simple. A plant that has developed the sensitive or sleep movement to a high degree is necessarily affected when light decreases. Thus, at the approach of a storm, when the sky becomes cloudy and dark, its leaflets quickly close together. The rain pelts down with the characteristic force of storms in the tropical countries where these extremely sensitive plants are found ; the leaflets, however, huddle still more closely together, for in that position they most readily throw off the water; and the probability of their getting damaged is, of course, comparatively small. So, in process of time, the leaflets would acquire the habit of drooping at the first spots of rain that touch them, and this quite independently of the influence of light-simply because the leaves benefit by the habit. This, I think, was how sensibility to touch was first acquired and manifested by these leaves. Later, when the habit had become fixed, they quite naturally drooped their leaves also when animals touched them; for they had learned that such was the proper and wise course to pursue whenever anything external came in contact with them. 
PLATE 33

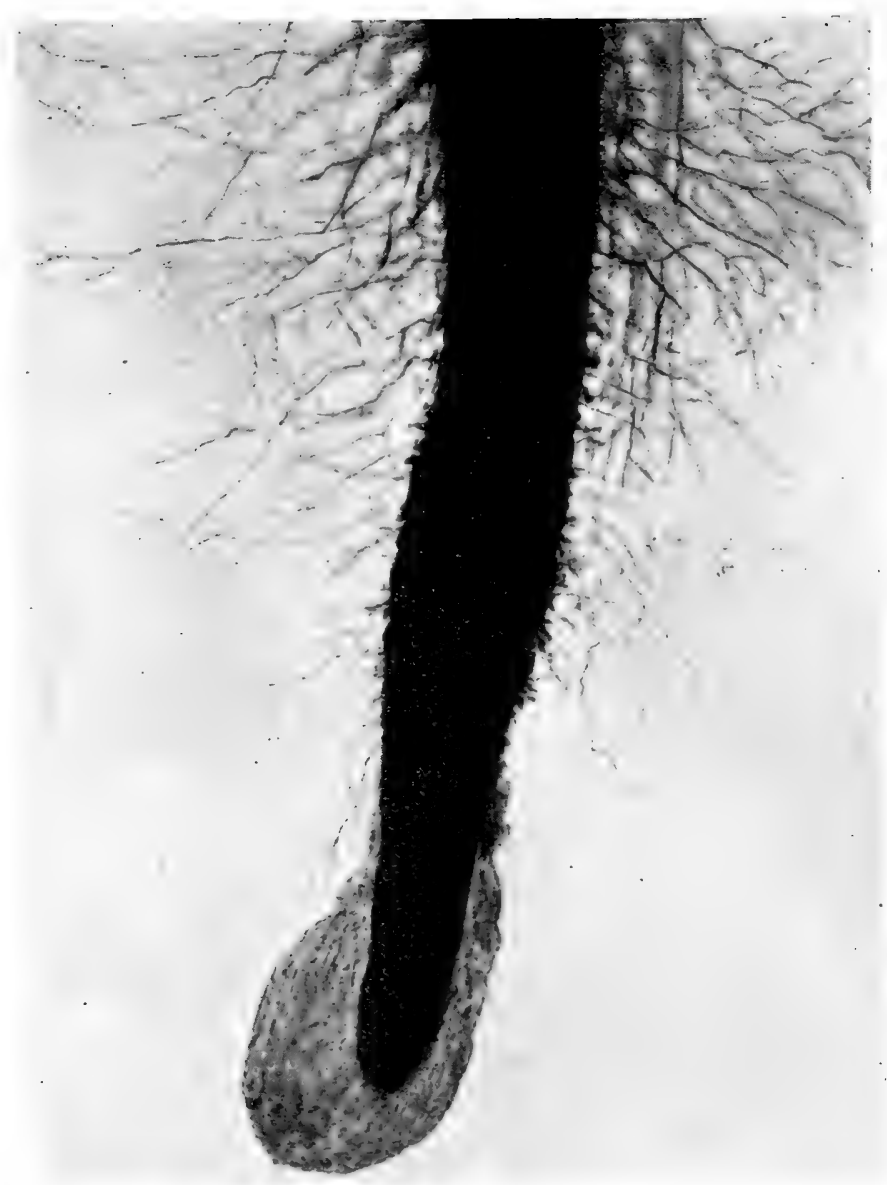

FIG. 50. - TIP OF THE YOUNG ROOT OF BARLEY, SHOWING ITS SENSITIVE ROOT-CAP (magnified) 
PLATE 34

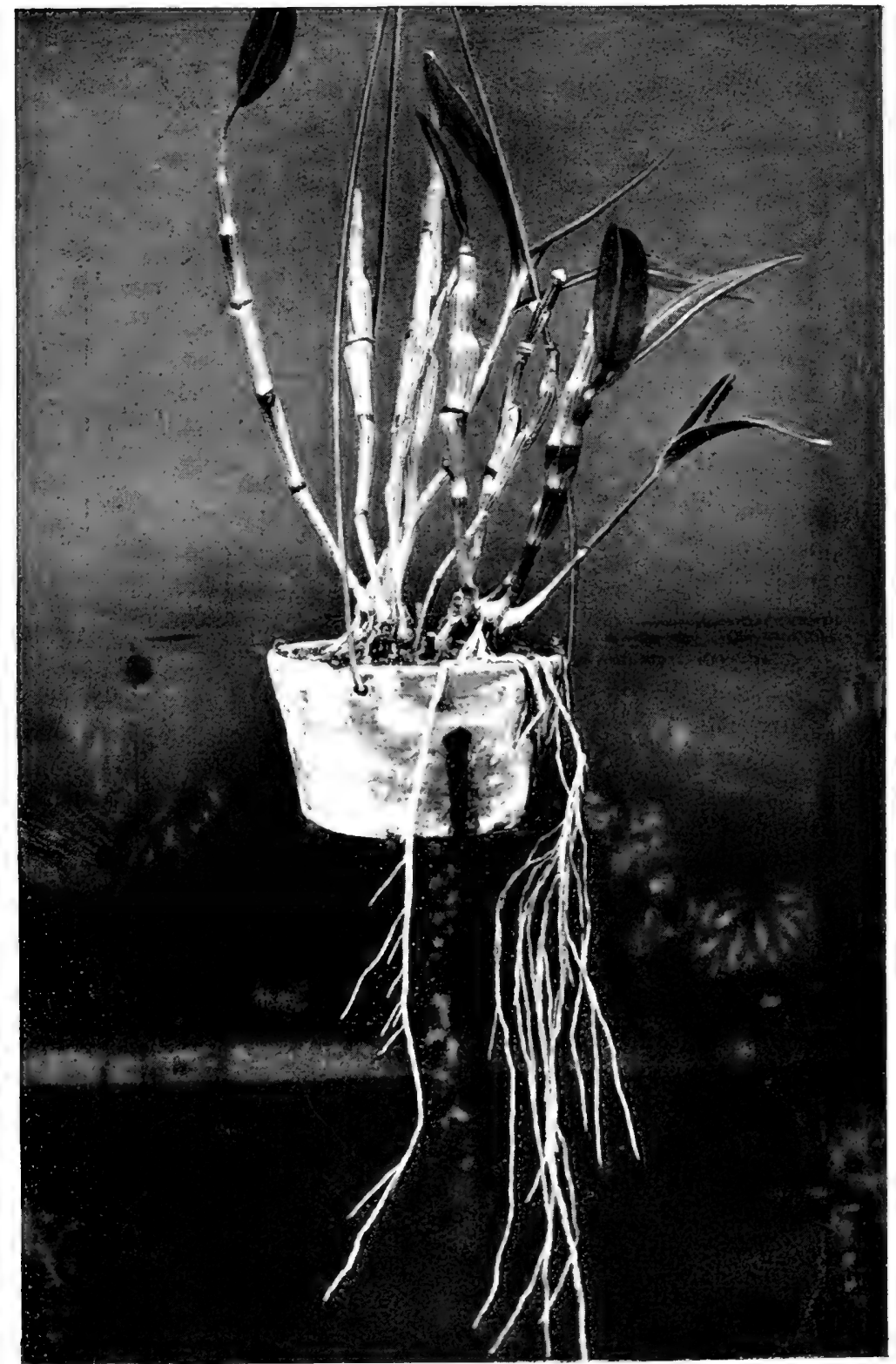

FIG. 51.-AN ORCHID WHOSE SENSITIVE ROOTS LEAVE THE POT AND FEED UPON THE ATMOSPHERE 


\section{SENSITIVE PLANTS}

So the sensitive plant developed its talent accordingly, and to-day we marvel at its cunning when it surprises and tricks the grazing animals and others of its enemies ; but we must not overlook the fact that there is in reality no such subtle discrimination and cunning in its manœuvres. The plant acts exactly the same if a spot of water is dropped upon its leaves as it would if a browsing animal touched them with its nose, or as when I blew at it before taking the photographs; indeed, the plant is quite unable to distinguish between these external influences. But, by the mere fact of these sensitive movements having served so good a purpose in its economy, they became hereditary, and were further evolved until the disturbance of the atmosphere caused by our approach, or by the movement of our umbrella, or by the change of light caused by our shadow being suddenly cast across their leaves, was sufficient to influence them; just as, in a larger degree, would the stronger wind and the greater darkness of an approaching storm influence them.

Sensibility in plants, however, does not begin, or end, in the leaf structures. It exists in the germinating seeds, and in every stage of their subsequent development. From the seed emerges a tiny root which penetrates the soil, but not as a piece of stick might do. The root-tip quite fastidiously selects its path amongst the interstices of the soil, seeking out moist places and avoiding such obstacles as will not provide suitable mineral food.

If you examine the tip of a young root by 


\section{LIFE HISTORIES OF FAMILIAR PLANTS}

means of a microscope (Fig. 50, Plate 33 ), you will find that it is protected by a thimble-like mass of loose tissue, or a "root-cap," as the botanist terms it. Within this is the true growing tip of the root, but it is the sensitive root-cap which guides the root-tip to suitable quarters, where it can set to work its army of delicate root-hairs, which it carries at its rear (see Fig. 50). It is by means of these root-hairs that the plant is supplied with water and mineral food, for the root-tip does not itself feed, nor does the sensitive root-cap. It is plain, therefore, that sensibility in plant structure manifests itself at a very early period.

This root sensitiveness is highly developed in some orchids, an example of which is shown in Fig. 5I (Plate 34). The roots of the orchid shown are seen to have left the pot which holds the plant and suspended themselves in the air; in their natural environment these orchids grow on, and adhere to, the bark of trees, but do not feed upon their hosts, simply using their branches as a support. Attaching themselves with a few root fibres, they then throw out into the atmosphere their feeding roots. The aerial roots are clothed with a paper-like covering, and when moisture is absorbed this membranous covering prevents it from evaporating from the root tissues; thus the orchids stand the long periods of drought; indeed, they become veritable vegetable camels, storing their water like the "ships of the desert" for a time of need. Yet so sensitive are these roots to their natural environment, the atmosphere, that if 

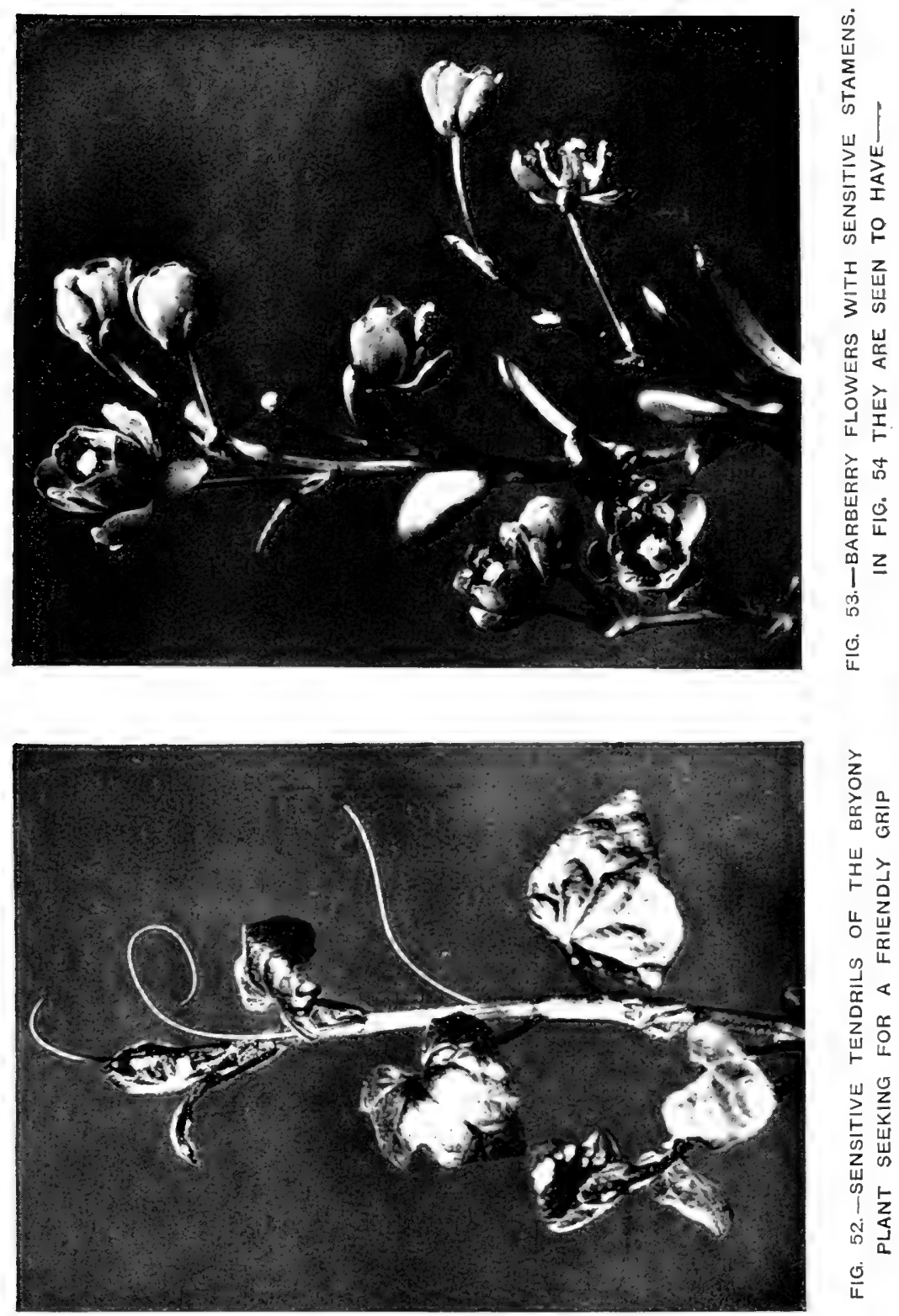

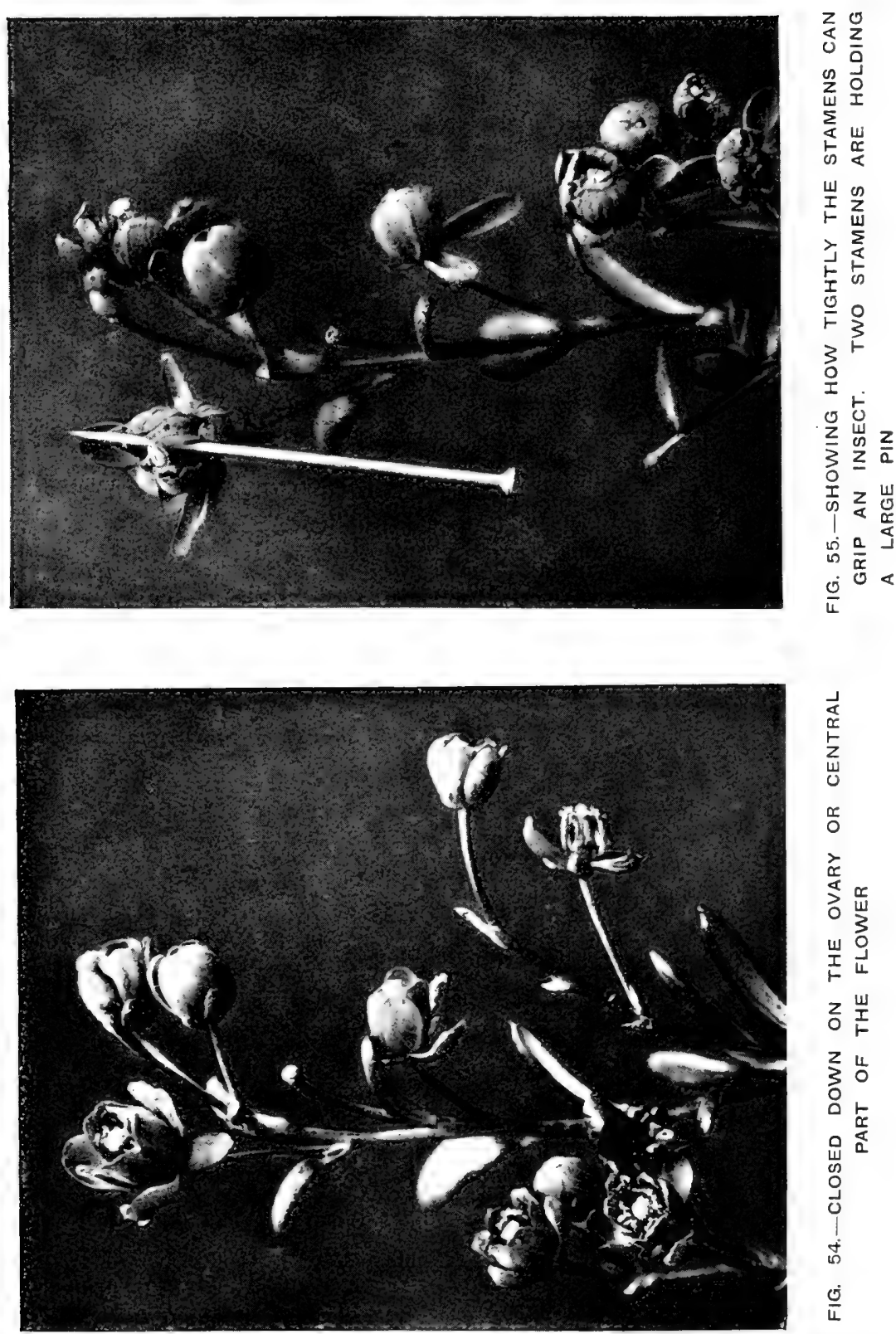
they are buried in the soil, or even laid upon it, the plant generally perishes.

Many seedling plants when they break through the surface of the soil, exhibit striking aspects of sensibility almost immediately. In Fig. 52 (Plate 35 ) is shown a young plant of the common bryony, the sole British representative of the Cucumber and Vegetable Marrow family: note how the climbing tendrils are stretching out into the surrounding air in various directions, diligently searching for a friendly grip that shall give them a pull up in life, that the plant may spread out its leaves to the sunlight. You have only to touch one of these tendrils for a few times at intervals to make it curve in the direction from which it was touched.

Thus, the young climbing plant springs up and develops its stem and leaves, just as all honest plants should do ; but, later, it reveals the worst side of its character, for it then sends out its tendrils which embrace the stems and leaves of neighbouring plants; and then over these stronger plants it scrambles at a reckless pace, spreading out its leaves and holding up its flowers to the fertilising insects-of course, much to the disadvantage of those plants which are gathered within its coils. Thus, by means of these sensitive tendrils it can, in the course of the summer, readily reach the hedgerow top with its weak stem and small stock of material; whereas its woody host has taken several years to get its leaves and flowers so high in the world. Most climbing plants present similar interesting aspects of sensibility. 


\section{IIFE HISTORIES OF FAMILIAR PLANTS}

Finally, I will take an example of sensitiveness in a flower. In the common barberry, the stamens, or pollen-producing organs, are extremely sensitive; in fact, they probably present the best example of active sensibility amongst British plants. You have but to touch the base of these stamens to make them spring instantly forward, towards the side of the ovary, or central part of the flower, which they bear against with considerable pressure. If the reader will look carefully at the central parts of the flowers shown in Fig. 53 (Plate 35), the light-coloured stamens will be seen opened out and pressed back against the petals. But if Fig. 54 (Plate 36) is carefully observed, the flowers there will be seen to be very different; their stamens have all closed towards the central ovary, and this is simply owing to the fact that I had touched the base of the stamens with the point of a pin-an interesting experiment that the reader may try at any time when the barberry is in flower. Cultivated species of barberry (such as that figured) and the common British species show alike this interesting feature of sensitiveness.

It remains now to discover what advantages the barberry derives from its sensitive stamens. With this purpose in view, I proceeded one afternoon to investigate. Almost every flower that I examined contained one or more small black beetles, each about half the size of a wheat grain ; there were thousands of them at work amongst the flowers, all as busy as it was possible to be. They were rifling the nectar of the twelve honey glands 


\section{SENSITIVE PLANTS}

arranged in pairs at the base of the petals in each flower; but not a single beetle reached those honey glands without causing some of the stamens to spring forward suddenly in the manner previously described. Beetles that were resting on the tops and the edges of the ovaries were being continually thrown into the centre of the flowers by the sudden jerk of the closing stamens when touched by another insect below, which had already reached the nectar. And there the dislodged insect would lie on its back struggling to regain its feet until its exertions, together with the movements of other agitated beetles, had brought forward every stamen in the flower. Some of the beetles were gripped between the heads of the stamens and the side of the ovary and held there until they could wriggle out of the clutch.

How tightly the stamens can grip an insect I have shown in Fig. 55 (Plate 36) where I have left the pin used to bring the sensitive stamens into action within the grip of two of themanother interesting experiment that may easily be performed with a little care.

The stamens open to shed their pollen by means of a kind of valve at the top, and with the sudden jerk forward the pollen is showered out at the valve, and falls in all directions amongst the struggling beetles within the flower; and therein lies the secret of the whole matter. Those black beetles, after being so roughly treated by the stamens, became yellow beetles, since to 


\section{LIFE HISTORIES OF FAMILIAR PLANTS}

almost all parts of their bodies the yellow pollen adhered. That the beetles enjoyed the nectar there was no doubt, but to get it they had to undergo a rough-and-tumble experience, whether they liked it or not. And this was the barberry's device for getting its pollen conveyed to other blooms, and for receiving pollen itself from other stamens for the pollination of its own ovary. Thus cross-pollination is insured, and that means fertile seed and the strengthening of its race. 


\section{CHAP'TER VI}

THE COMMON PRIMROSE (Primula vulgaris)

A SUNNY bank bespangled with primroses is irresistible to the country rambler. The sweetscented, pale-yellow flowers are so attractive that to gather a bunch of them follows almost as a natural consequence. But the part they play in this appeal to our lighter human interest often obscures from us certain deep-laid schemes in their economy by means of which they have become possessed of nearly the whole bank, carpeting its surface with their green, crinkled leaves and establishing their colony in every vacant spot favoured by the sunlight. In the haste of gathering their flowers we fail to notice that every little detail of their structure-whether of leaf, or flower, or underground stem and root-has its meaning and purpose in the order of their evolution.

The primrose occasionally favours the open woods, but it revels most in a sunny bank. There it has every facility for carrying out those hereditary tactics which its remote ancestors have found good for their race. Early in the spring its green leaves warily peep up above the surface of the soil, but they do not then look like primrose leaves. They stand erect, each little leaf like a 


\section{LIFE HISTORIES OF FAMILIAR PLANTS}

short green stalk, for the right and left halves of the blade of the leaf are rolled tightly back and only the midrib, or central vein, is visible. Slowly these little stem-like leaves elongate and thicken, but not until the sunlight makes its warmth felt, do the green parts of the leaves unroll and spread themselves out; then, almost in a few hours, the plant presents quite a bold array of leaves, followed almost immediately by a show of flowers. The primrose is a perennial, and prepares for this sudden display of spring by accumulating, during the previous summer and autumn, a large store of rich starches and energyyielding materials in its underground rootstock. Hence, at the earliest favourable moment it is ready to begin business, and so it gets an early start over many of its competitors for space and sunlight.

Its near relative the cowslip (Fig. 56, Plate 37), which grows on the lower ground amongst the pastures, is usually later in getting its blooms forward, simply because it has to develop a long and thick stalk to carry its umbel of flowers. In that respect the primrose has made a distinct advance; it no longer produces a stalk to hold up its flowers. Its stalk is so abbreviated and stunted that the flowers appear to spring directly from the root, although they really arise from the summit of the undeveloped stem. Indeed, I am inclined to think that the primrose is the most advanced member of its genus. It would be rash to dogmatise in the matter and declare positively whether the 

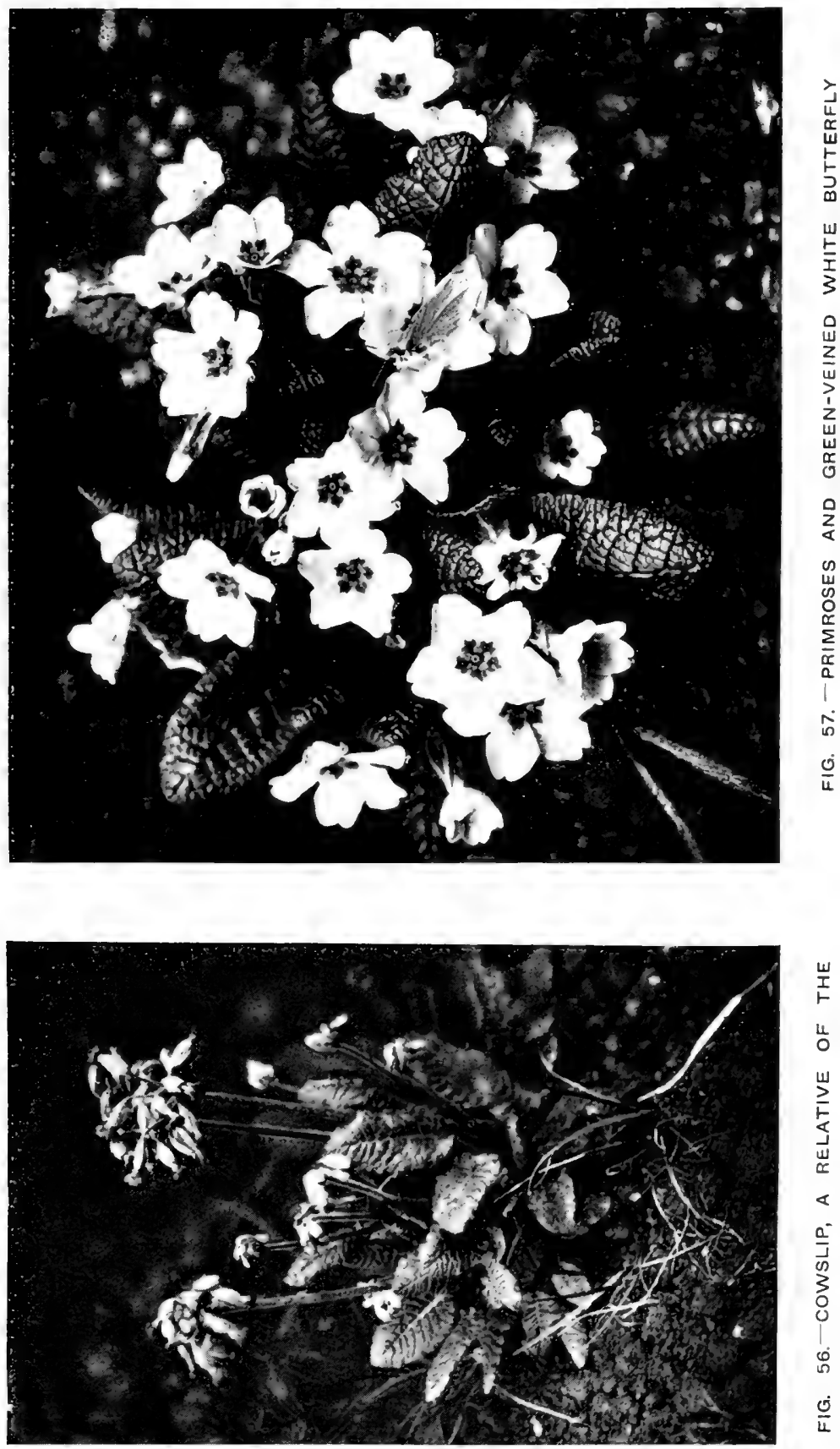

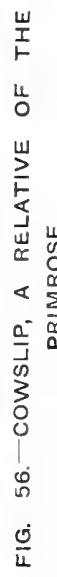




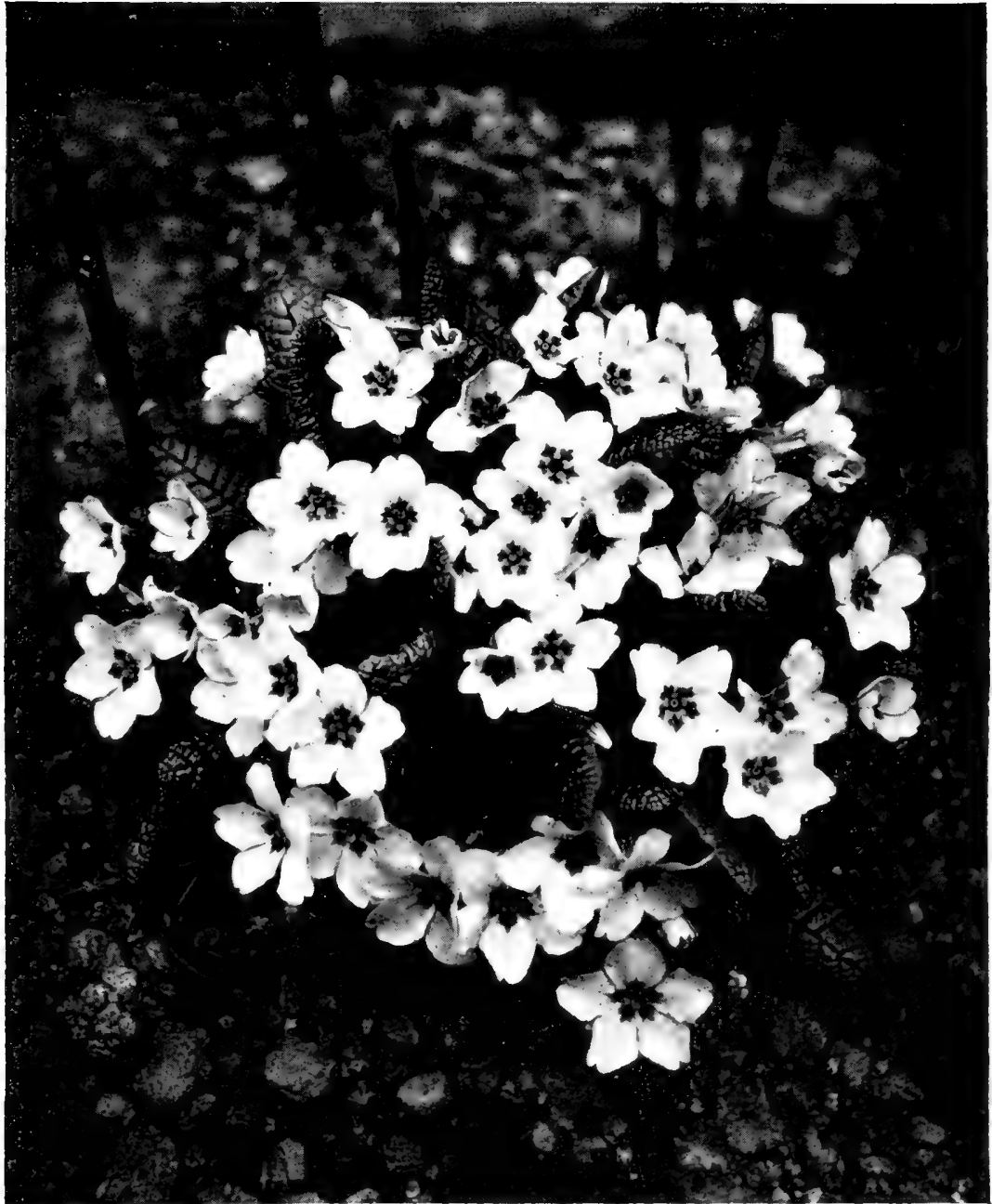

FIG. 58.-THE FLOWERS PRESENT A BOLD SHOW THAT IS CONSPICUOUS EVEN AT NIGHT 


\section{THE COMMON PRIMROSE}

primrose or the cowslip is the more advanced, for some might say that the cowslip, by reason of developing its long stalk and holding up its blooms more conspicuously to the insects, has attained a higher development than its relative the primrose.

It happens, however, that of the four or five species of British primulas all bear their flowers on leafless stallis, such as that of the cowslip, with the single exception of the common primrose. Now, seeing that the primrose has particularly selected the sloping hillside as its home, it is obvious that its flowers would there be visible to the insects without requiring the use of a long stalk. On the other hand, the cowslip that chooses the lower pastures needs its stalk to make its blossoms conspicuous. Moreover, the primrose having no length of stalk to develop would have more material to utilise in the formation of its flowers; hence we find the flowers of the primrose much larger than those of the cowslip.

In northern England the Bird's-eye Primrose (Primula farinosa) is sometimes found, which is a mountain-loving species of Europe, Asia, and even of the Arctic regions. According to the principles stated above, this species-growing on mountain sides-should scarcely need a flower-bearing stem. In fact, however, it possesses one much. longer than its leaves. But, owing to their habitat, these plants have to protect themselves against heavy dews, and we therefore find that this species, along with other plants of quite - different families, have their foliage protected by 


\section{LIFE HISTORIES OF FAMILIAR PLANTS}

a waxy covering. When grown in shady places this protective covering will often disappear, for in such situations there are no alternating heat and moisture.

It follows, therefore, that the bird's-eye primrose would benefit by retaining its flowerstalks in its mountain situation, since its flowers would thus be held higher above the moist earth and therefore kept drier; and the fact that, not only the flower-bearing stem, but also the calyx of each individual flower, is well protected by the waxy secretion, points to the conclusion that the flowers take considerable risks of this kind. Thus this seeming contradiction to my contention regarding the primrose scarcely stands investigation : it only tends to show that, as the bird'seye primrose experiences more varied conditions of temperature than the common primrose, the plant finds it better to retain its flower stem.

The primrose provides its insect guests with a widespread corolla, but that of the cowslip is not so large and the flowers of the latter are pendulous, and thus receive their visitors from below. These differences may arise from the fact that each plant caters for insects of a different class. It is surprising how seldom insects appear to visit the flowers of the primrose, yet Darwin has conclusively shown that when the flowers are protected from the visits of insects few or no seeds are produced; probably, therefore, their fertilisation is largely effected by nocturnal insects. A mere glance at the structure of the flower offers con- 


\section{THE COMMON PRIMROSE}

vincing evidence that it is especially adapted to insects with long tongues, such as bees, butterflies, and moths ; probably it is the last two mentioned (Fig. 57, Plate 37) that are most desired, for, although bees occasionally visit the flowers yet their visits are not nearly frequent enough to account for the large quantity of seeds produced.

Also, the large pale-coloured corolla of the primrose points to the conclusion that it is adapted for nocturnal visitors; moreover, the flowers mass themselves against the dark green leaves and present a bold show that is conspicuous even at night. Figs. 57 and $5^{8}$ (Plates 37 and 38 ) explain this better than any description. The cowslip is more often seen to be visited by diurnal insects, but, nevertheless, it also probably depends chiefly on nocturnal visitors; for, although it cannot make much display with its small corolla, yet it makes up this deficiency somerwhat by distending its calyx slightly and developing it of a pale green colour, sometimes almost white, so that the floral mass then stands out boldly (Fig. 56, Plate 37).

Both the coloured petals and the green sepals of the primrose have united their lower parts and thus form a double tube. The upper parts of the petals spread out as a platform for the fertilising insect to alight upon. There is only one way in which the insect can reach the nectar, namely, by inserting its long proboscis or tongue down the central tube. In Fig. 59 (Plate 39) two primrose flowers are shown, and it will be observed that in the example on the left the centre of the flower is 
occupied with a pin-like head or stigma. In the other example, the mouth of the tube is seen to be closed with five little oblong stamens all covered with yellow pollen.

Now, watch the occasional bee that makes a visit to these two different types of flowers. Here is one alighting. With the sudden weight thus imposed upon it the flower sways; the bee, however, adroitly balances it again and proceeds to bury its head amidst the five pollen-laden stamens, while its long tongue is thrust down the tube to sweep up the nectar, although this latter action is concealed from us. The bee then withdraws its sucking-trunk, hums, and away it goes to another flower on a neighbouring plant, and there performs similar manœuvres.

These actions of the insect are all very commonplace, of course, but nevertheless some wonderful functions have been carried out while we watched the bee visit these two blossoms. An examination of the second flower visited by the bee will show that the mouth of the tube was not occupied with stamens but with the pin-like head of the stigma, as shown in the example on the left of Fig. 59 (Plate 39). In Fig. 60 (Plate 39) the two forms of flowers appear in section. It will there be seen that in the "pin-eyed" flower the stamens occur about midway in the tube, while in the other example the pin-like head of the stigma is similarly placed. Thus the positions of the stigma and stamens are exactly reversed in each flower. 
"PIN-EYED

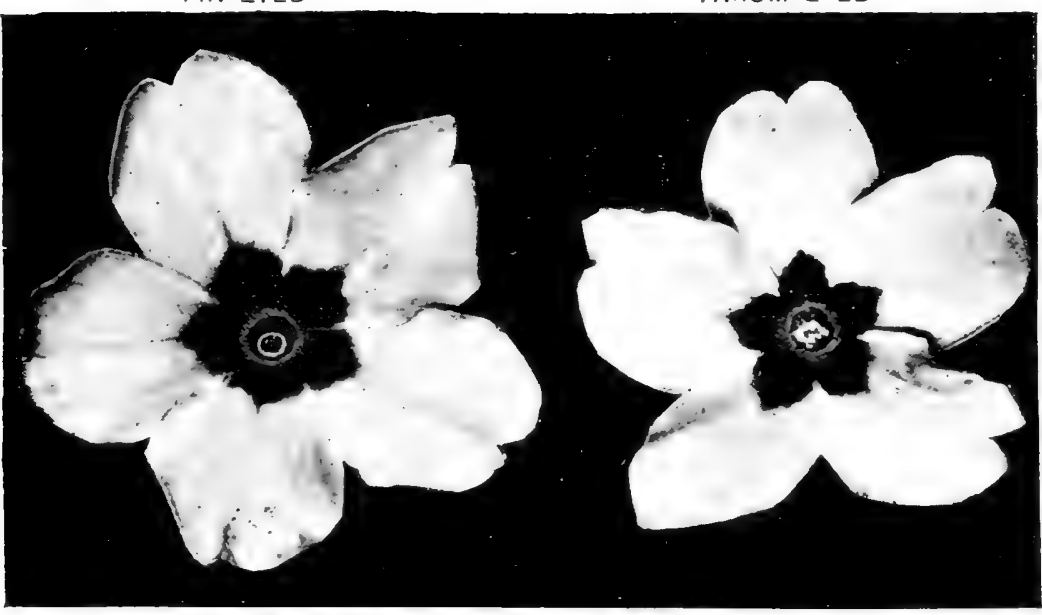

FIG. 59,-THE "PIN-EYED" AND "THRUM-EYED" FORMS OF FLOWER

"THRUM-EYED"

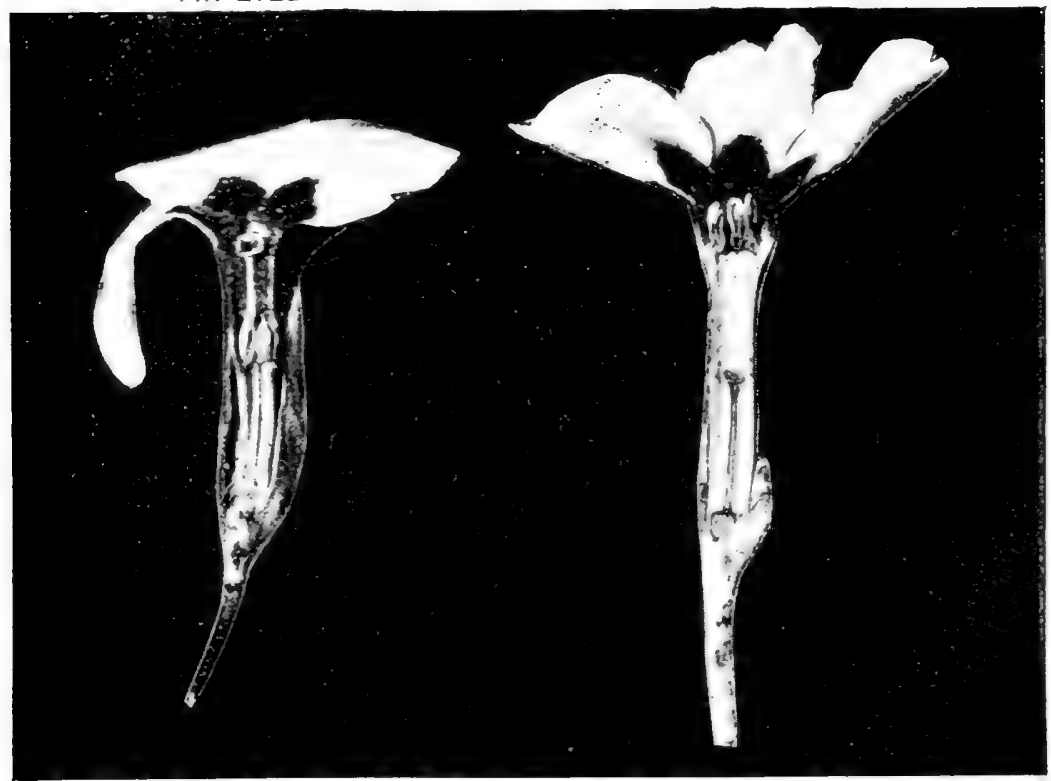

FIG. 60. -THE "PIN-EYED" AND "THRUM-EYED" FLOWERS IN SECTION 
PLATE 40

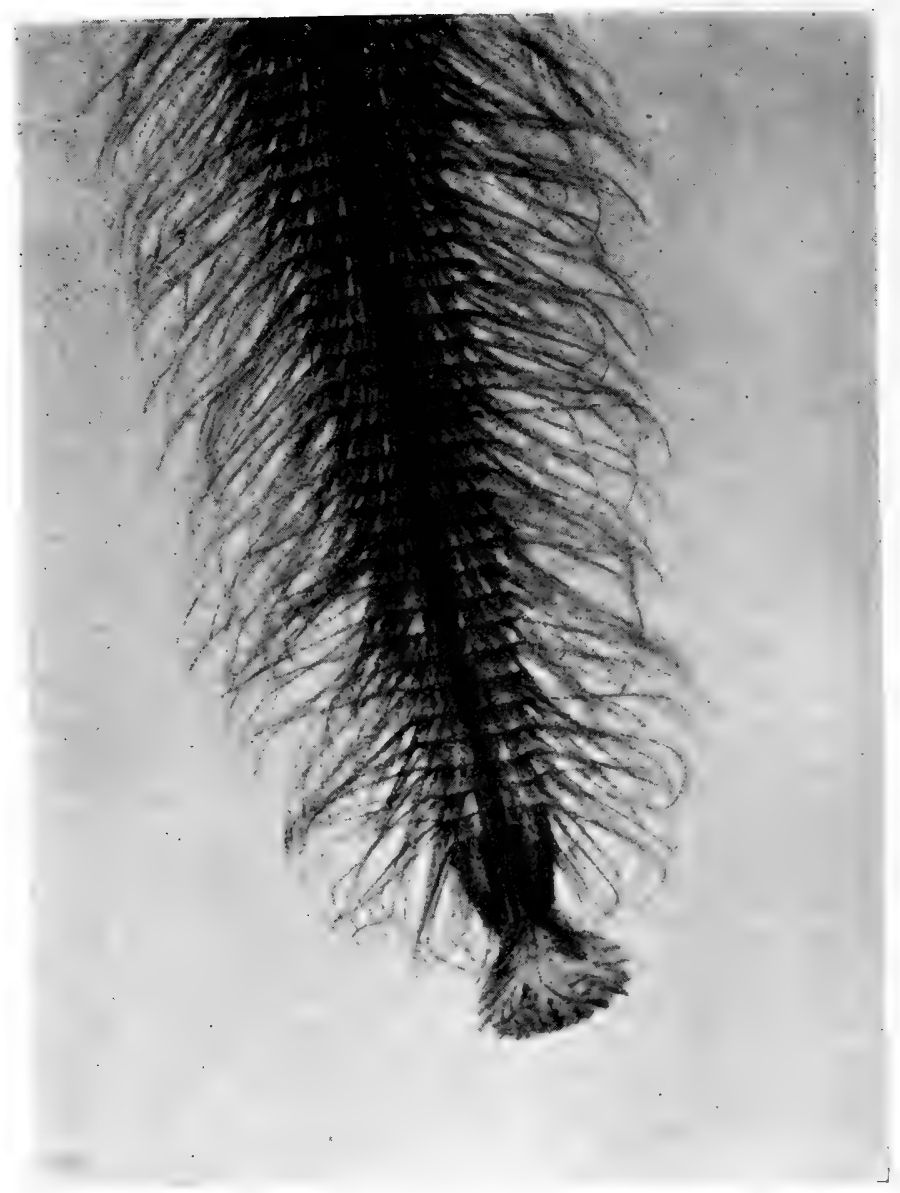

FIG 61.-MAGNIFIED VIEW OF THE END OF THE BEE'S PROBOSCIS 


\section{THE COMMON PRIMROSE}

These two different forms of flowers grow apart on distinct plants, and although they had been long recognised by botanists and gardeners, yet it required the master-mind of Darwin to point out the significance of their contrasting details, and to reveal one of the commonest and most effectual means of cross-fertilisation, not only in the Primrose family but in numerous other groups and genera.

It is plain that the bee, having burrowed its head amongst the pollen-laden stamens in its effort to reach the nectar at the base of the tube, and then visiting another blossom having its stigma at the mouth of the tube, must convey some of the yellow pollen dust to that organ ; for the stigma comes in contact with the exact part of the bee's anatomy previously dusted by the stamens. Such, then, are the functions of "thrum-eyed" and "pineyed" primroses, as they are commonly called; they are simply contrivances to effect cross-pollination by the agency of long-tongued insects. The stigma is rough and sticky to receive the pollen; and when the pollen germinates and fertilisation takes place, much larger quantities of seed are produced where the pollination of the stigma has been effected with pollen from stamens of a corresponding level : i.e., the "thrum-eyed" pollen on the "pin-eyed" stigma; indeed, Darwin has shown that only by that means can full fertility be attained. Conversely, of course, the stigma of the "thrum-eyed" form requires pollen from the stamens midway in the tube of the "pin-eyed" type. 


\section{LIFE HISTORIES OF FAMILIAR PLANTS}

To appreciate properly the beauty and perfection of this arrangement of the primrose, one has also to consider the tongue or proboscis of the insect that assists in the pollination of the flower. Therefore, in Fig. 6I (Plate 40) I have shown a magnified view of the end portion of the proboscis of the bee. It only needs a glance at this figure to understand how readily this organ can remove the pollen from the stamens midway in the tube as it searches for the nectar, and, on visiting a flower of the "thrum-eyed" type, convey such pollen to the stigma there. The proboscis, indeed, acts as a kind of brush sweeping up the pollen within the tube, while the sticky stigma coming in contact with this pollen-laden brush naturally gets well dusted over. Should the insect not visit alternately the two types of flowers, no harm is done; only more pollen has accumulated for the first alternating form that it eventually reaches.

It will be understood that the "pin-eyed" stigma in the mouth of the tube gets pollinated from the pollen gathered by the base of the proboscis, or perhaps the head of the insect. The whole scheme is beautifully and perfectly organised. The butterfly and the nocturnal moth in a like manner uncoil their tongues and search the depths of the tube and perform a service similar to the bee. However, we should not fail to remember that they have no thought of pollinating stigmas; the object of their search is the sweet nectar, and doubtless the stamens, stigmas, and pollen greatly impede their movements, but, 


\section{THE COMMON PRIMROSE}

the primrose produces nectar in its own utilitarian interests, and offers it to the insects as the price for their services in effecting its pollination.

It may seem probable to some of my readers that the bee or moth would, when withdrawing its proboscis from the stamens midway in the tube of the "pin-eyed" form of flower, dust some of the pollen it had gathered on to the stigma in the mouth of the tube, and so bring about self-fertilisation, or that it would perhaps convey such pollen to the stigma of another " pin-eyed" flower rather than to the lower stigma of a "thrum-eyed" blossom where it would prove most fertile. If we pass a bristle down the tube of the flower, such almost invariably happens. However, we are then working with a clumsy tool, but the insect is no such clumsy worker. By means of its legs it balances the flower and adroitly pulls the tube to one side so that its flexible proboscis gets a clear way, and the chances of misplacing the pollen then are very unlikely. Occasionally a careless insect may deposit some pollen wrongly, but conditionally upon some being properly conveyed, the latter, being more fertile, will hold its own and more quickly effect fertilisation. Indeed, the complex organisation of the flower, so perfectly constructed for the class of insects that patronise it, distinctly points to the conclusion that such insects perform the work of pollination with complete efficiency.

Thus have the non-sentient tendencies of the primrose, inherited in the course of long ages, attained a degree of high complexity and perfection. 
How successful the method of fertilisation adopted by the primrose has proved to be, is shown by the progress that the plant makes when it obtains a foothold in suitable haunts. The flowers are at first produced largely at the expense of the material gathered during the previous autumn, but afterwards the leaves begin to develop at a great pace, flattening out and monopolising as much ground as possible. Other flowers are produced at intervals, but the work of the plant is now to ripen its seed-pods that are hidden among the leaves. Meanwhile the stalks which bear the pods go on elongating, and by the time that the seeds are ripened, the pods lie near to the edges of the leaves among which they are hidden. Eventually the pods burst, and the seeds get lodged amongst the crinkled leaves. At the slightest disturbance of the leaves by wind or other agency, some of the little seeds shake from amongst the leaves, and these being down-turned at their ends give impulse to the seeds, with the result that on the tumbled slopes where the primrose thrives best, they get scattered to some distance from the parent plant; and so the primrose gains new ground for its offspring and its species.

The parent plant, after scattering its offspring, then spreads out its leaves even more than ever, to assimilate from the atmosphere those materials that it requires in the building of the store of rich starches for the production of its leaves and flowers during the following spring. Eventually, nipping frosts occur, and the thick clump of leaves slowly 


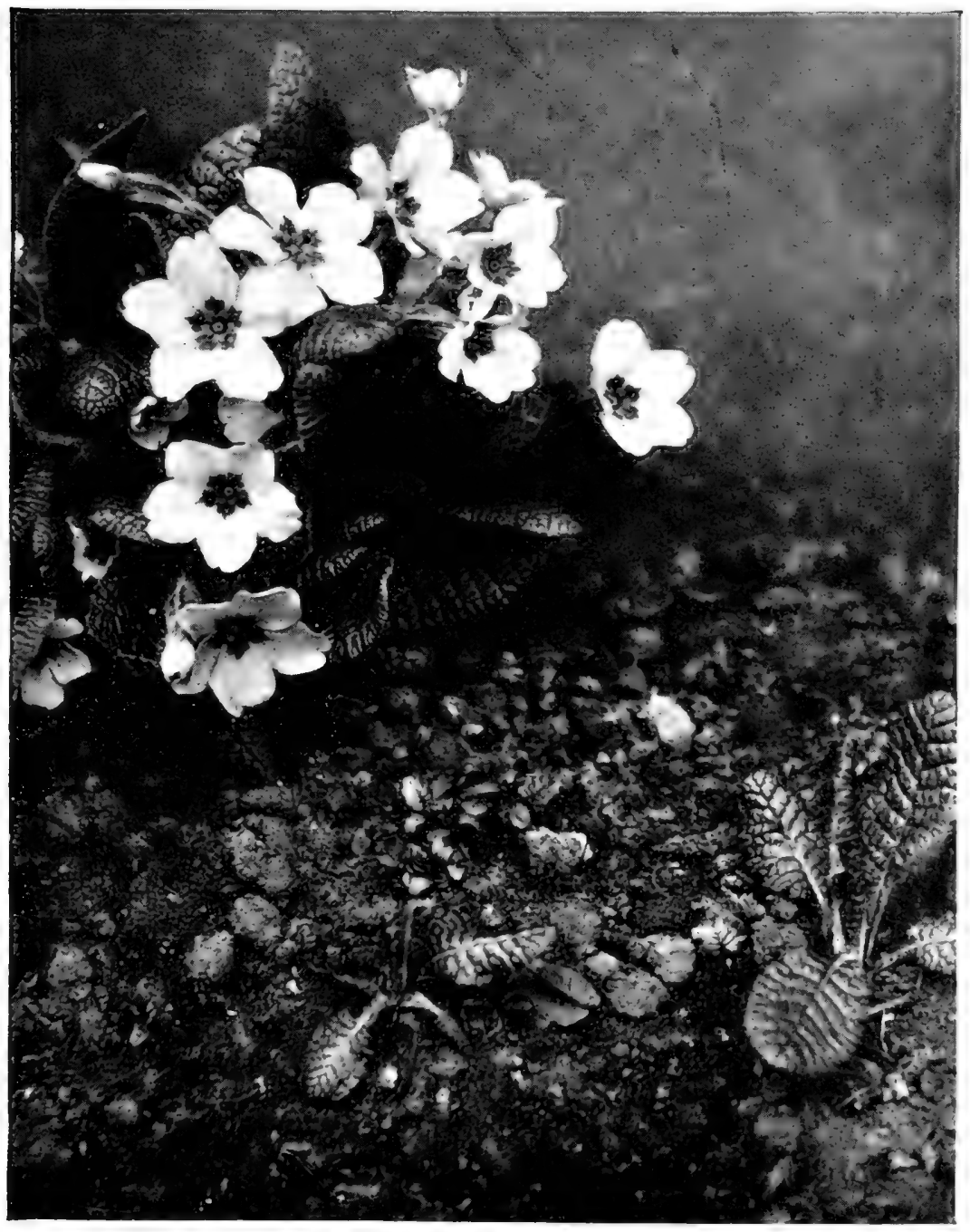

FIG. 62.-THE OFFSPRING GROWING UP AROUND THEIR PARENTS 


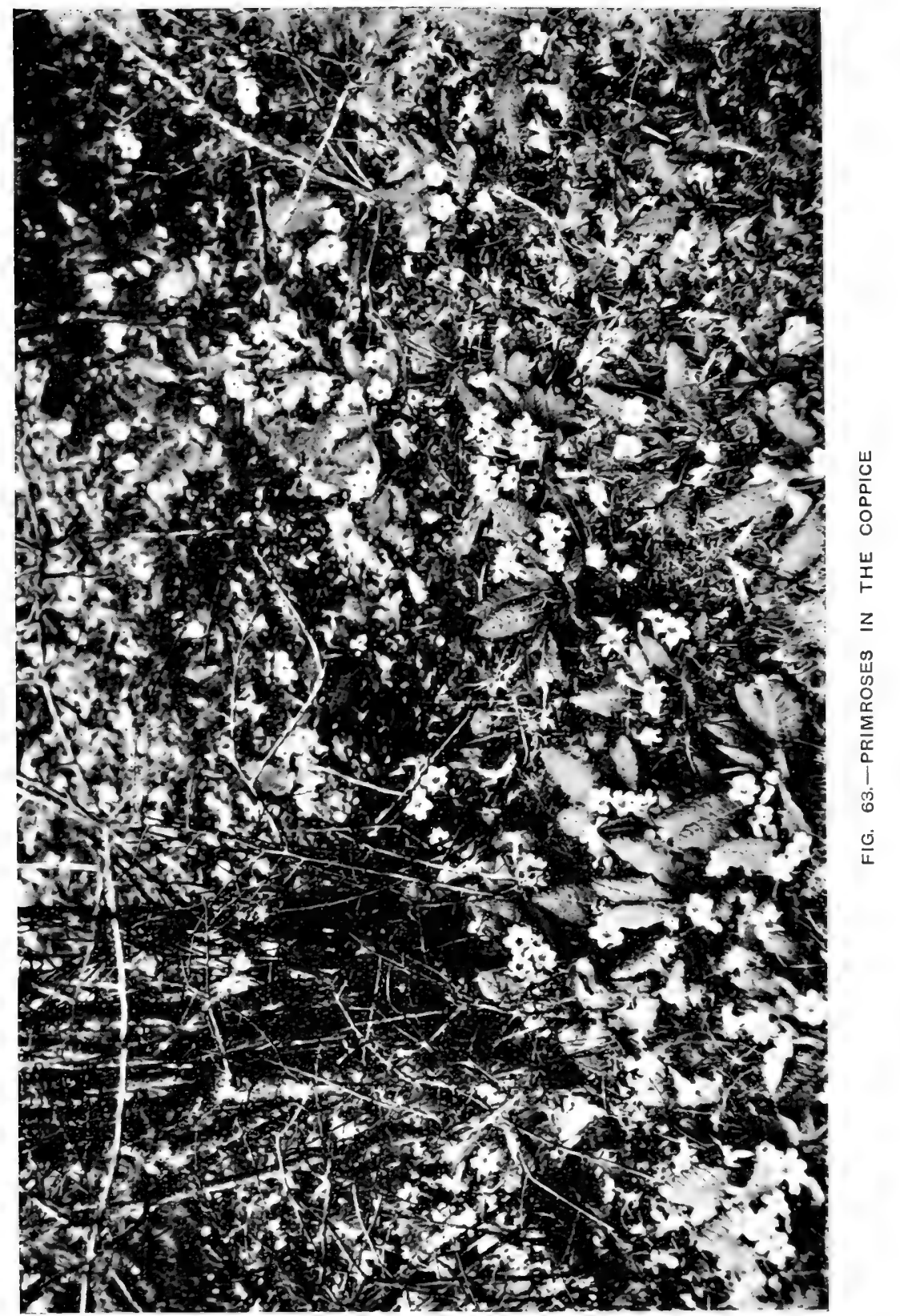




\section{THE COMMON PRIMROSE}

yields to winter's icy grip-but not before ample food-stuffs are safely stored below ground.

The seeds germinate, and in the following spring, by the time the parent plant has got its leaves well above the ground, the offspring plants appear in little clusters round about it. Later we find them growing up under the eyes of their parents, as it were (Fig. 62, Plate 4I). It will take each little plant more than one year of growth to produce a clump of leaves and a show of flowers like those of its parent, but that is the way in which the natural flower-bed on the hillside, which has now crept down into the coppice, was gradually formed (Fig 63, Plate 42). 


\section{CHAPTER VII}

LABURNUM (Cytisus laburmum), BROOM (Sarothammus scoparius), AND GORSE (Ulex europaus)

IN May and June the familiar laburnum makes a strong appeal to our æsthetic tastes. Its graceful, pendent racemes of yellow blossoms are conspicuous in many a shrubbery, enlivening by contrast the green foliage which has so recently appeared to clothe the branches, and now fills up almost all the intervening spaces amongst them. The laburnum never looks so beautiful, however, as when growing near a full bushy tree of deep red may, or hawthorn. I have just seen it thus neighboured, and when the late afternoon sun was casting its glow fully upon it. It was separated from its ruddy neighbour by a dark green yew tree, making altogether a most charming and delightful combination of colour that instantly arrested the attention and held it captive for some minutes.

My enthralment terminated somewhat abruptly, however, when I suddenly remembered that I was a roaming botanist, travelling down to yonder heath, where I knew the broom and gorse bushes would be flaunting their golden flowers. But before I go I am going to beg from the good lady standing at the gate a small branch of these 


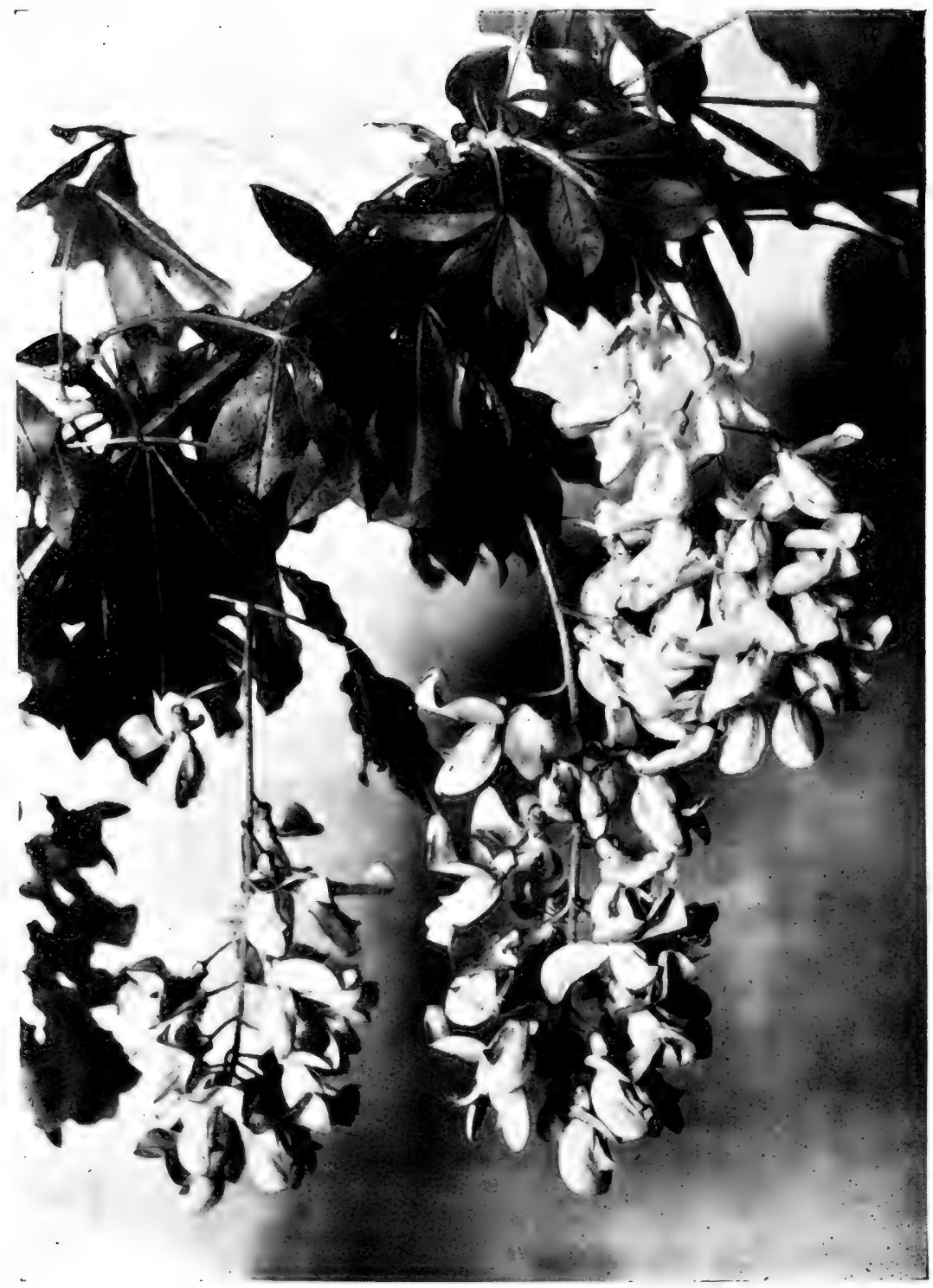

FIG. 64.-LABURNUM 



\section{LABURNUM, BROOM, AND GORSE}

yellow laburnum blooms. I know by her kindly smile, while I have been admiring the trees, that she will tell me to help myself. There! She is asking me if I would like "a bunch."

Now, if you will come with me to where the broom and gorse grow, I will endeavour to show you some details with regard to this garden tree and these wild shrubs that you may not have noticed.

There is no mistaking where the broom lies. In the hollow of the heath there is a blaze of golden yellow, such a display of that colour which no other British shrub or tree can produce. The gorse, or furze, that grows in the same situation, runs it close when at its best, but the larger flowers that so crowd the branches and seem all desirous of greeting the sunlight and the bees together, and the greater height of the bush, leave no doubt that the broom is the predominating painter of the landscape.

Alongside this branch of laburnum that I have brought let us place another of broom and still another of gorse (Figs. 64, 65, and 66, Plates 43, 44, and 45). It becomes obvious at once that the flowers of each are very similar. Each bears a butterfly-like blossom, or, if you prefer it, a peaflower. But we may leave the flowers for a moment while we glance at the leaves.

Each leaf of the laburnum is seen to consist of three somewhat oval leaflets borne on a long stalk. The broom has much smaller leaves, the lower ones on the branches having very short 


\section{LIFE HISTORIES OF FAMILIAR PIAANS}

stalks with three tiny leaflets, similar in shape to those of the laburnum. Amongst the upper parts of the branches, however, you will frequently find that the leaves are stalkless and composed of only one leaflet. To seek for leaves on the gorse is a hopeless task, for its leaves, and also its branches, have all been converted into sharp thorns. That the gorse once had trifoliolate leaves something like those of the laburnum, or the lower stalked ones of the broom, I will endeavour to make clear presently.

Now, these three plants all belong to one very large family; a family which stands next in importance in the vegetable world to that dominant group of Composites that includes the wild camomile, which I have considered in Chapter I. Their flowers at once denote that they are individuals of the great Pea-flower family, which includes the favourite sweet peas of the garden, the cultivated peas and beans, the wild peas, the vetches, and the clovers. The leaves of peas and wild vetches are composed of a number of separate leaflets arranged in pinnate fashion along the stalk.

Indeed, if you take a leaf from the laburnum and look at the piece of bare stalk that bears the three leaflets at its apex, you can readily understand that by placing a few similar opposite leaflets along the stalk you at once produce the pinnate leaf so characteristic of the Pea-flower family. The same thing would apply equally well to the trefoil leaves of clover. Of course, in the peas and 


\section{LABURNUM, BROOM, AND GORSE}

vetches the terminal leaflets are usually converted into tendrils, to assist these weak-stemmed plants in reaching the sunlight. Just in the same manner, too, the leaves of the laburnum, broom, and gorse have been modified from the type of their common ancestor best to serve their individual requirements.

Of the three plants in question, the laburnum has probably seen fewest vicissitudes in the course of its evolution. Its stout trunk, large leaflets, and long pendent racemes of flowers, all indicate that it has not been harassed very considerably. Growing as it does on the mountain slopes of France, Switzerland, and Southern Germany, and often so placed as to be inaccesible to browsing animals, it has apparently been able to develop its structure and spread out its leaves and flowers without much interference.

Its leaves are produced in little clusters arranged along the branches; the larger ones have long stalks, which allow them to extend beyond the smaller ones. It follows, therefore, that, if the longer leaves possessed the pinnate leaflets characteristic of its family, the smaller leaves would be covered by them. In the present arrangement, however, the smaller leaves fill in the intervening spaces, and so all the leaves get exposed to the sunlight. Also, by clustering the leaves together and exposing them to the sunlight on the upper sides of the branches, it allows a clear way beneath in which to suspend the racemes of flowers (see Fig. 64, Plate 43). 


\section{LIFE HISTORIES OF FAMILIAR PLANTS}

When the flowering stem first appears amongst the leaves, it also occupies the upper side of the branch and stands erect, but as soon as its flowers have matured sufficiently to invite the bees to pollinate them, the stalk bends over and elongates, and so the raceme is suspended below the branch where the fertilising insects are well able to see it. By doing this, however, the flowers become placed upside down, i.e., the large overhanging petal, or "standard," becomes lowermost. This difficulty is surmounted by each flower then twisting half round on its stalk; thus the flowers are brought into their correct positions to receive the fertilising bees. The laburnum has met its little difficulties well, and has apparently made fairly smooth progress throughout its development.

Let us now endeavour to read the history of the broom also by considering its structural details. Why are its trifoliolate leaves so small? Well, the ancestral broom has, in the course of its history, learned that on the hilly wastes and open places where it makes its home, the production of large leaves is a mistake, and means a waste of valuable material. Indeed, it is trying its level best to do without leaves altogether, in proof of which you have its frequent tendency to produce leaves of only one tiny leaflet.

Those plants which develop leaves in such open situations necessarily have to protect themselves against the attacks of browsing animals; thus we find nettles, thistles, brambles, dog-roses, hawthorns, blackthorns, and similar heath-loving species all 


\section{LABURNUM, BROOM, AND GORSE}

well protected with stings or thorns against the attacks of their soft-nosed assailants. Yet the broom, without a single sting or prickle to protect it, grows alongside its well-armed neighbours and there holds its own, and fearlessly lifts into sight its golden blossom.

The broom, nevertheless, has not been able to overlook this all-important matter of protection. It does not however, seek to drive off its enemies with the point of the bayonet; its method is of a far more peaceful kind; it prefers to starve them off. From bitter experience it has discovered that its leaves offered the most tempting morsels; a serious problem to face, indeed, because the leaves are its feeding organs. They absorbed its gaseous food from the atmosphere from which it largely builds its structure. Nevertheless, the broom has slowly worked out its own salvation. It has gradually reduced its leaves in size until they have become so insignificant that they are scarcely worth the attention of herbivorous animals.

How, we may well ask, has the broom been able so to dispense with those all-important feeding organs, its leaves? If you will glance at the wiry branches, you will find that these are green, and therein lies the broom's secret; its branches now largely carry on the functions of its lost leaf area, and owing to some bitter and nauseous deposit within them, these branches are distasteful to browsing animals and consequently are left alone so long as other food is obtainable. 


\section{LIFE HISTORIES OF FAMILIAR PIANTS}

The flowers of the broom do not appear in pendent racemes but in solitary ones, or occasionally in twos, along the wiry branches. A pendent raceme of flowers, like that of the laburnum, on these erect branches would be altogether in the wrong place, so we find the flowers arranged in orderly fashion on the rigid branches for the bees to see them. Thus the broom, owing to difference of habitat, has developed on quite other lines than its near relative, the laburnum.

Having thus accounted for the difference between the laburnum and the broom, the gorse now remains for consideration. Why has this close relation of the broom, both of which thrive in identical situations, found it necessary to arm itself so elaborately? The answer to that question is, I think, that the difference came about originally when the two species first diverged from the ancestral type.

Assuming that, in the natural and unceasing variation of living things, some of the offspring of the remote family ancestor happened to develop in their tissues a bitter property that made them distasteful to herbivorous animals, such individuals would be more likely to survive than those which were not so protected. This protective feature, since it conferred an advantage on those individuals that preserved it, would be intensified in future generations, and in that manner the broom would slowly evolve as a distinct species, and perfect its acquired protection. The dwarfing of its leaves and the carrying on of their functions by 
the stems, would probably follow later according as such modifications helped the progress of the species.

Such variations from the parent type are always taking place, for no two individuals of a species are exactly alike. It follows,- therefore, that some other individuals of the ancestral stock may, in the course of such variations, have developed leaves or leaflets with a tendency to produce sharp points or edges that irritated the soft noses of depredating animals. Again, such individuals would derive protective advantages by means of this variation, and by the natural law of heredity such advantages would be handed down to their offspring, and be further evolved and strengthened in the generations that followed.

So the gorse, like the laburnum and the broom, is probably a descendant of the same common ancestor, but a descendant which has gone on modifying its structure in a different direction until its trefoil leaves have entirely disappeared; for although we cannot say just what the ancient type was like, yet I think it would be fairly safe to assume that it possessed yellow pea-flowers and leaves of three leaflets. Probably the still more remote ancestor of the Pea-flower family had more than three leaflets, and these pinnately arranged on the stalk, as in the vetches; for I am inclined to think that the trefoil leaf is a development from the pinnate form. Indeed, there are species which bridge over the trefoil group to the manyleafleted vetches, such as the bird's-foot trefoil, 


\section{LIFE HISTORIES OF FAMILIAR PLANTS}

which usually has five leaflets, while in the kidney vetch the upper leaves often produce numerous leaflets, but in the lower ones there is generally one terminal leaflet of a large size, with a few smaller ones along the stalk. Such species seem to indicate how the trefoil form has most probably been evolved.

Assuming that the gorse differentiated from the family type by a tendency to develop foliage of a thorny character, its tissues, nevertheless, would be just as palatable to its herbivorous enemies, supposing that they were able to resist the prickliness. While food was abundant, however, such plants would be left alone, just as would the individuals of the broom species that developed a bitterness in their tissues; thus the species steals a march on its enemies, and only at times, when the more palatable species were scarce, would attacks be made upon the protected species. During the intervals of attack, though, the bitter property of the broom would be continually increasing, and the gorse would be ever perfecting the points of its thorns, until at last each species, by its own particular method of protection, would be able to stand defiant before their enemies on the open heath, just as we find them to-day.

Where goise is regularly cut down, the annual shoots make a fodder that is greatly appreciated by horses and cattle after it has been bruised sufficiently, by chopping, to deaden the prickles ; many a wayfaring horse is grateful for such a meal of green food during the winter months. Also when 


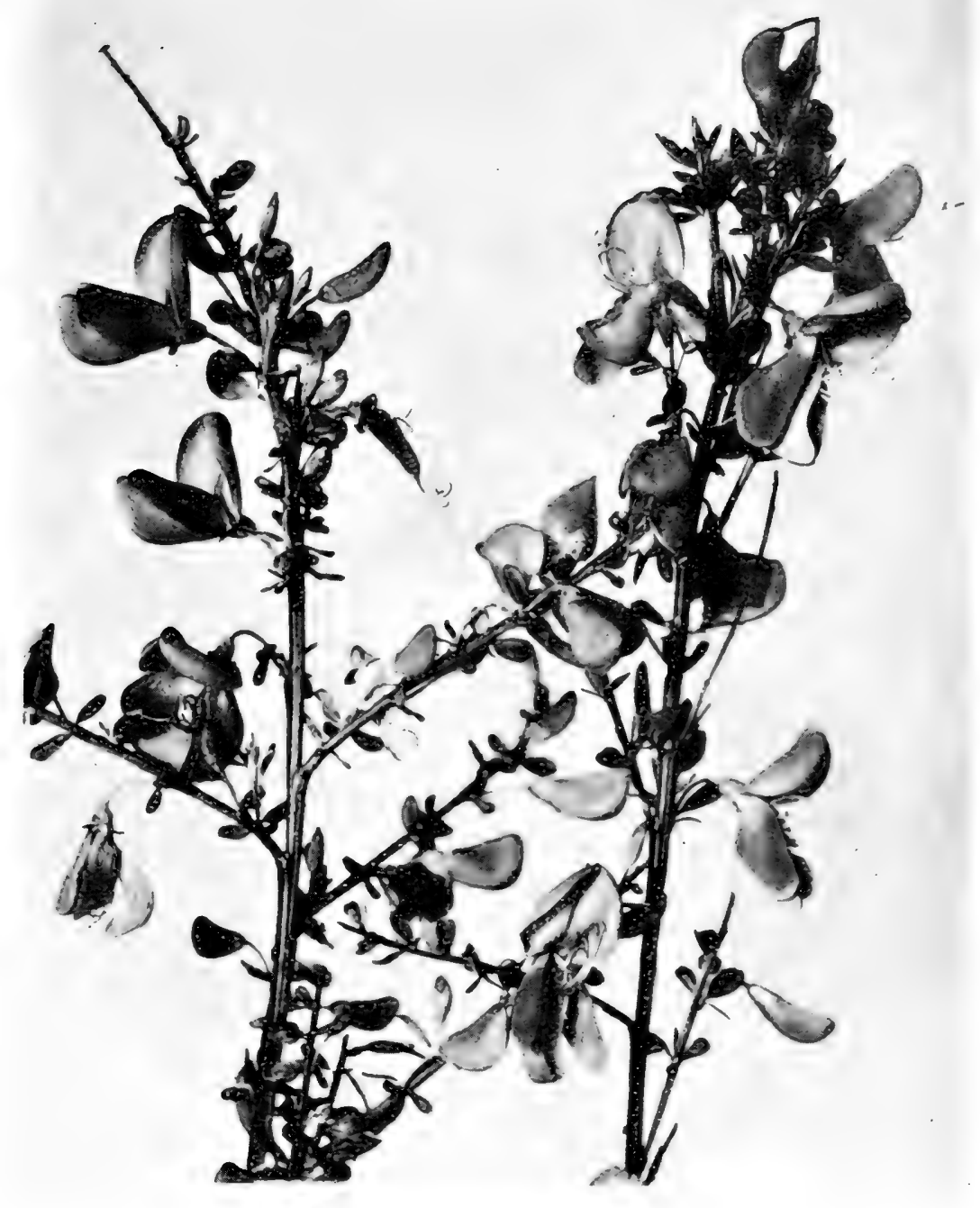

FIG. 65.-BROOM 


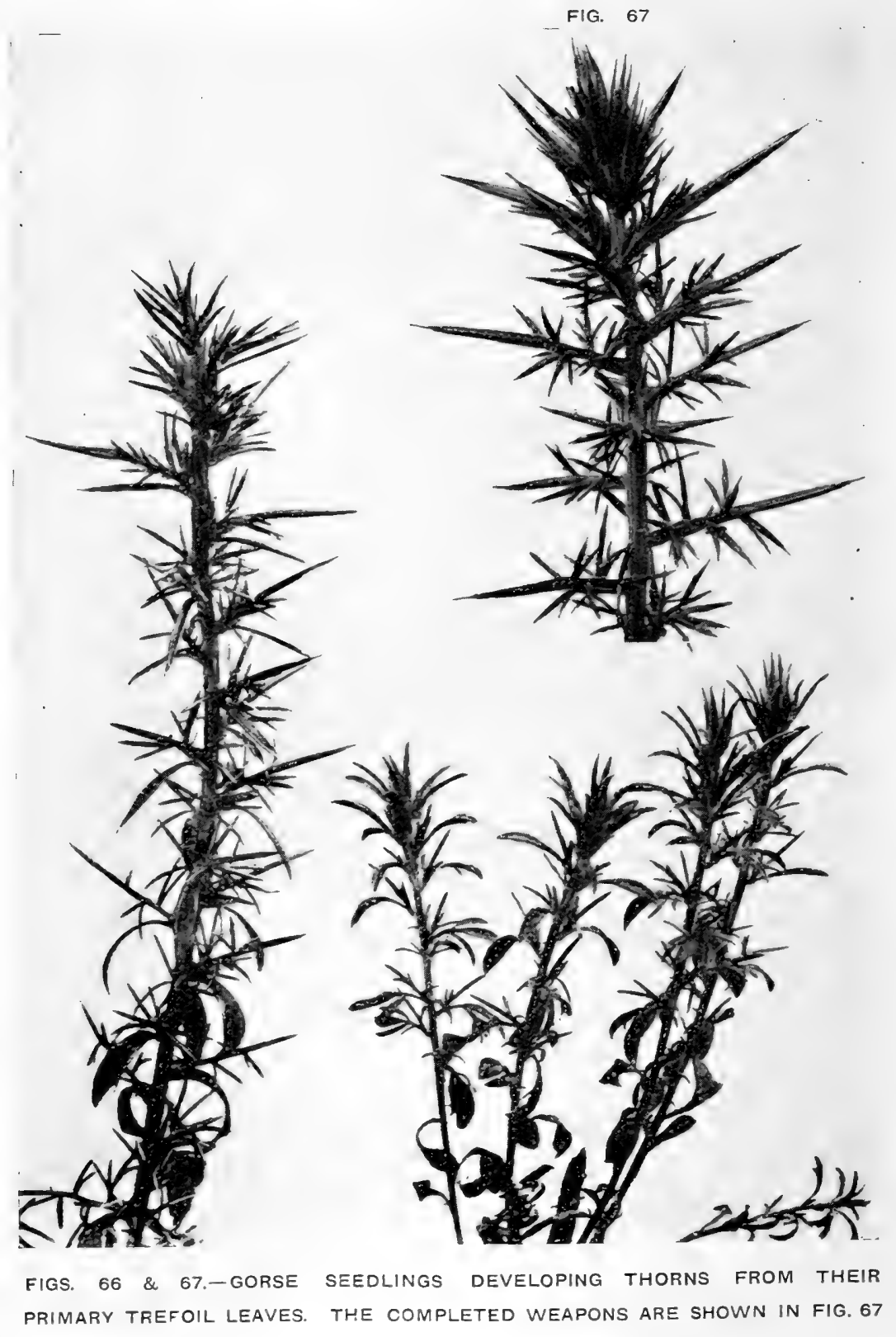




\section{LABURNUM, BROOM, AND GORSE}

the young shoots appear above the ground they are greedily nibbled down by rabbits and larger animals. Therefore, on the open moors, where the gorse has made its home, the development of a prickly armour was an absolute necessity. What proof have we, however, that the gorse did really possess trefoil leaves-like those of the broom or laburnum-which characterise its family?

You have but to search around some gorse bushes and find a seedling plant to get a complete answer to that question. The young plant tells its own story, for after its seed-leaves have appeared above the soil they are quickly followed by trefoil leaves, similar in form to those of the fully developed broom. In Figs. 66 and 67 (Plate 45), the matter is clearly explained. The lower leaves of the young seedling will be seen to be three-foliolate. As the stem develops, some of these leaves change into three-parted spines, while others lose two of their leaflets, the central one remaining, as in the upper leaves of the broom. Still higher up the stem the leaflets get thinner and sharper, gradually changing into thorns, as the upper example on the right of Plate 45 well shows.

Indeed, each young plant records in miniature the whole evolution of its species, from its trefoil stage until it has developed a complete armour of thorns. Amongst the changing leaves appears, here and there, a large thorn which has developed well in advance of the leaves. Such thorns are the modified early branches of the young plant, and their appearance in this order tells us that first the 
ends of the branches developed thorns, and that the device proved so effective that later the individual leaves each acquired a protective point, the tissues of which hardened at the expense of the substance of the leaflets until it had absorbed them and developed into a stout thorn.

Thus, there is ample reason to suppose that the now unassailable gorse was once a soft-leaved plant whose leaves consisted of three leaflets, like other members of its family, but that it was driven perforce into arming itself against persistent animal attacks, and so thoroughly did it carry out the work that, to-day, it represents the most perfect example of bayonet protection amongst British plants. Consequently it can thrive on the open commons and moors, with its most dangerous enemies ever around it, but none of which now dare approach to nibble at its branches.

The gorse, like the broom, in seeking protection from animal attacks has had to reduce its leaf area. Its branches and smaller thorns consequently are green like the branches of the broom. The green thorns, of course, represent the leaves, and, together with the branches, they carry on the functions of leaves. Also, it should be observed that by thus hardening the leaves into thorns, the gorse is enabled to do away with the annual "fall" of its leaves in autumn, and so becomes an evergreen. Therefore, although its leaf area is limited, yet, in view of the fact that it can absorb sunlight energy and gaseous food on every bright day throughout the winter, while most 


\section{LABURNUM, BROOM, AND GORSE}

other plants are denuded of their leaves, it probably derives advantages rather than disadvantages from the change.

After all, then, the laburnum, broom, and gorse, although presenting such different aspects, are, at the bottom, closely connected, and are simply divergent descendants of some ancestral form, a form that may itself have ceased to exist ages ago. Yet, by the mere examination of the structural details of these apparently dissimilar plants, we are now enabled to read their past histories and trace their relationships; indeed we can go farther and form a mental picture of that remote ancestor from which they diverged.

Botany, I know, has a bad name, and is looked upon by many as a dry and uninteresting science, but when a brief study of three common plants reveals glimpses into the unceasing warfare that has, throughout the ages, ever been fought. between plants and animals, and shows that only those species have survived that have utilised to the utmost their opportunities, surely it cannot be so dry-as-dust a science as it is sometimes made out to be.

It is true that the science of botany may be pursued by different methods from those I have adopted in this chapter. I might, after examining these three familiar plants, have arrived at the conclusion that they were Dicotyledonous Phanerogams of the division Calycifloræ, and the natural order Leguminosæ, belonging to the sub-order Papilionaceæ. I might further have added that 


\section{LIFE HISTORIES OF FAMILIAR PLANTS}

the broom belongs to the genus Sarothamnus, the laburnum to the genus Cytisus, and the gorse to the genus Ulex, and that their scientific names are Sarothammus scoparius, Cytisus laburmum, and Ulex europaus, respectively. Such information would convey to the scientific botanist much of what I have previously explained by another method. While I have no particular objection to dry science myself, I am rather inclined to think that the general reader prefers his dry science somewhat adulterated. However, I have put the matter both ways, and my readers, therefore, may make their own choice. 


\section{CHAPTER VIII}

SOME STRANGE GREENHOUSE PLANTS

IT is in the greenhouse, where tropical and subtropical plants are cultivated, that we most often meet with strange and weird-looking plants that do not seem at all to conform to our ideas of plant form as it should be. Indeed, the average person is far too prone to look upon plants as necessarily consisting of a stem, branches, leaves, flowers, and roots. However, only a small proportion of the world's plants possesses all these organs; some plant species carry on their life functions without either leaves or branches, and others without flowers, and still others without roots; also, there are numerous minute species that possess none of these organs, their rhole structure consisting only of a single microscopic cell that moves and lives in pond or sea-water. Such unicellular plants are, therefore, altogether without stem, branches, leaves, flowers, and roots.

In the British climate, most of the plants with which we are familiar are able to develop their parts more or less completely, but in the tropics and warmer regions of the earth where plant life is more abundant, and the struggle for existence is necessarily more keenly fought, plants have to resort to all sorts of strange manœuvres and H 


\section{LIFE HISTORIES OF FAMILIAR PLANTS}

devices to live and hold their own. Thus it is that, when we visit a well-stocked greenhouse, we find many quaint and curious plant forms that puzzle our understanding. On the greenhouse shelves, standing side by side amid incongruous surroundings strangely uncouth, these plant novelties have no meaning, simply because they have been gathered from all the corners of the earth where conditions and environment are entirely different. To understand their (to us) unusual forms and quaint structures we have to consider their natural habitat and the conditions under which they live, together with the enemies they have to combat. Also, when we observe what appears to us as a quaint plant form, we should remember that it is really not quaint at all, but that its extraordinary features are the outcome of its struggle for existence and represent that form in which the plant has best been able to survive.

It would be a poor collection of tropical plants that did not include some specimens of the curious Cactus family. Some examples are shown in Figs. 68, 69, and 70 (Plates 46 and 47). Most species of this family are natives of California, Mexico, and South America. They grow in arid plains where, after a short rainy season, they are subjected to perhaps several months of unbroken drought. In such quarters the scorching sun shrivels up everything of the nature of thin-textured leaves, hence the cacti have completely dispensed with their leaves, in short, their whole structure has been condensed into one thick, fleshy mass; the mass assuming 


$$
1
$$


PLATE 47
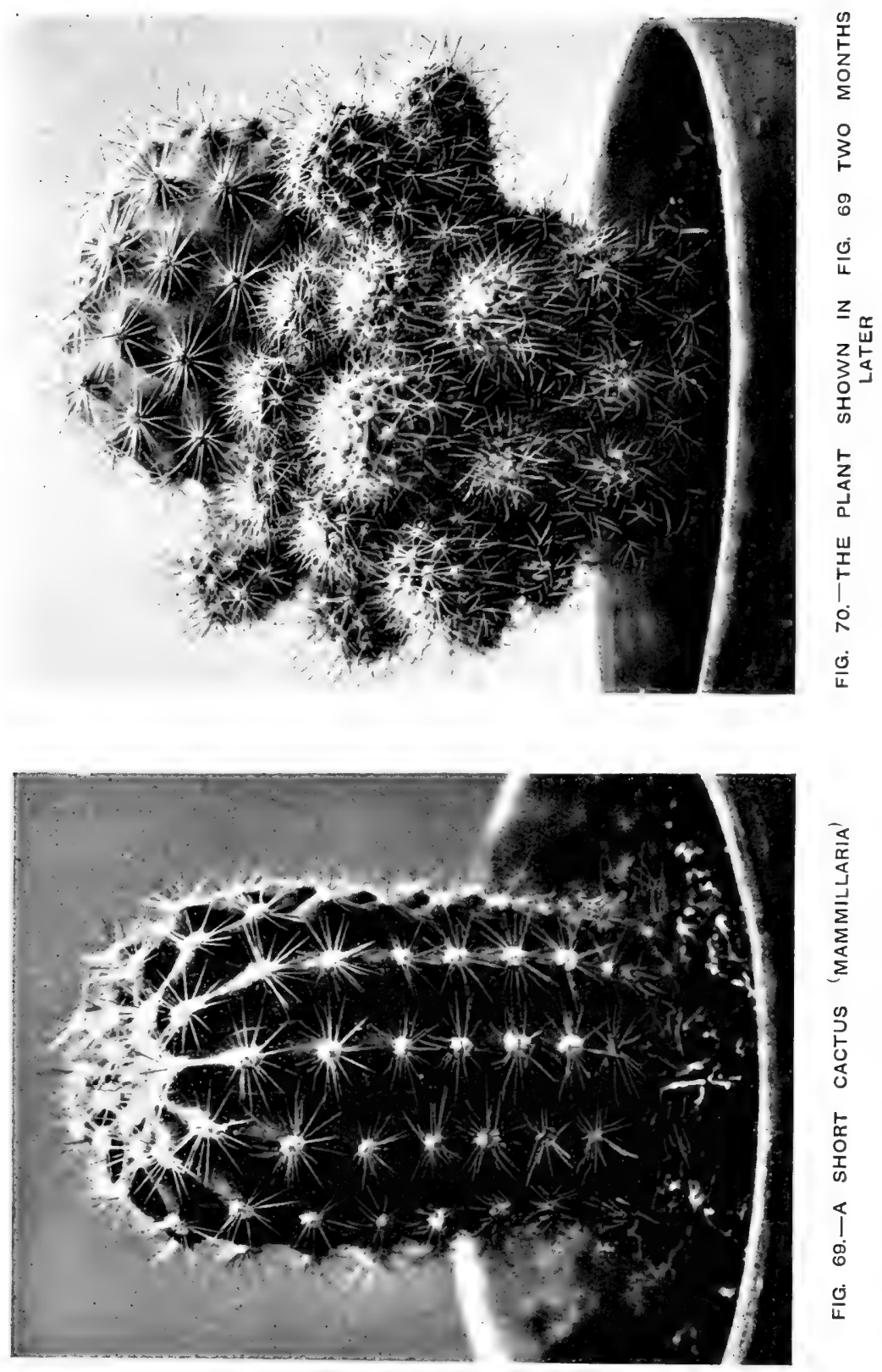


\section{SOME STRANGE GREENHOUSE PLANTS}

various forms from globular to cylindrical, and varying in size, according to the limits of the particular species. Now, what benefits do the cacti derive from this modification of their structure?

In the first place they obviously run no risk of getting their leaves scorched by the hot rays of the sun ; in the dry atmosphere, their thick fleshy structures can retain moisture in a manner that no plant bearing ordinary branches and leaves could possibly do. This is the keynote to their success; these cacti have become storehouses of water against the time of drought. In the rainy season they fill up their tissues with moisture; then comes the long dry period, during which, however, their water is not evaporated by the burning sun, for their outer covering skin is so thick and strong that it retains the moisture within the plant tissues; indeed, these cactiform plants have been very aptly termed "vegetable camels," from the fact that they provide themselves with large quantities of water while it is obtainable, and store it against the time of need, which in such lands is bound to come.

Being without leaves, the leaf function of feeding on gaseous foods from the atmosphere has to be carried on by the plant body as a whole, hence we find that its solid stem or globular mass is green; the green colouring matter being essential to the feeding process. Now, by this concentration of material and storage of moisture, these plants expose themselves to considerable dangers 


\section{LIFE HISTORIES OF FAMILIAR PLANTS}

from the attacks of animals inhabiting the desert districts where they grow-hungry and thirsty animals, ever roaming and seeking succulent material that will quench their thirst.

On the sandy and sun-scorched plains, when every spring has long dried up, and all ordinary green plants have become shrivelled and burnt, the tempting reservoirs of the cacti stand out fresh and green, surviving throughout the greatest droughts; yet the goaded animals, maddened, and sometimes almost dying with thirst, rarely attack them. You have but to make a slight acquaintance with cactiform plants to learn the reason why!

There are no plants on the earth more fearfully armed and, conversely, there are no plants that need greater protection. The leaves they once had have all been modified into sharp and irritating bristles and stout spines with points that can inflict terrible wounds on an attacking animal. Sometimes a single species will possess several forms of weapons, all arranged one with the other to offer an unassailable protection; hence it happens that animals will rather starve than attempt to reach the nourishment that would sustain their lives. Occasionally, wild horses and asses will make an attack by kicking at the plants with their hoofs, in this way exposing some of the softer internal tissues, but even these strong animals often get severely in. jured and not infrequently lamed as a result of their efforts.

Sometimes the cacti are protected only with IOO 
simple rosettes of bristles arranged about their surface, and although it is not possible in individual cases to connect the weapons they produce with the particular foes against which they have to defend themselves, yet the spiny and bayonet protection increases according as the species inhabit drier and more desert regions.

Why some species produce a long straight stem or column and others more or less globular masses is also difficult to understand; sometimes their prickliness serves a double purpose, as, probably in the case of the example shown in Figs. 69 and 70 (Plate 47), where the plant is seen to have budded out numerous offshoots, all as bristly as the original.

The barbed bristles and hairs not only make these offshoots unpalatable to their particular animal foes, but also serve to distribute the plant ; and perhaps by the agency of their foes. The offshoots are easily detached and cling like burs to the fur and hairy paws of animals that move amongst them. In this manner they are carried for considerable distances, eventually being removed by the animal, or falling to the ground, where they throw out roots and develop. Each quaint form assumed by a cactiform plant, then, is full of meaning in the economy of its species.

By way of contrast to these desert-loving cacti, which, in order to live have to suppress their leaves, let us turn to another plant (Fig. 7I, Plate 48) growing in a moister part of the greenhouse. What a different story does this caladium tell! Leaves 


\section{LIFE HISTORIES OF FAMILIAR PLANTS}

measuring several feet in length (compare their proportions with the shelves and potted orchids) present a gorgeous display of colours, white, green, pink, and crimson. Each fully developed leaf is large enough to make a handsome natural sunshade, but I fear that it would be of short service.

Such a large expanse of leaf denotes quite a contrary state of things to that with which the cactus has to contend. It tells of moist, open situations where the leaves can spread themselves out in safety to the shaded light. Plants which grow in, or by, open rivers and pools, like the common water lilies and the water dock, can afford to spread out their leaf tissues in this manner, because they have abundant moisture and few enemies, and scarcely any competitors to contend with for sunlight. So it is with the largeleaved caladiums which grow in moist open places in the warmer regions of the globe, as the West Indies, Sandwich Islands, Brazil and other tropical countries.

I may also point out that this plant belongs to the Arum family, whose British relative we have considered in Chapter III. The leaves are seen to be similar in shape to those of the familiar British species, and an examination of the floral parts of the caladium would still further show its relationship. Yet how immensely different are the two plants; the British species living in a temperate climate and inhabiting the overcrowded, moist woodlands and watery ditches, 


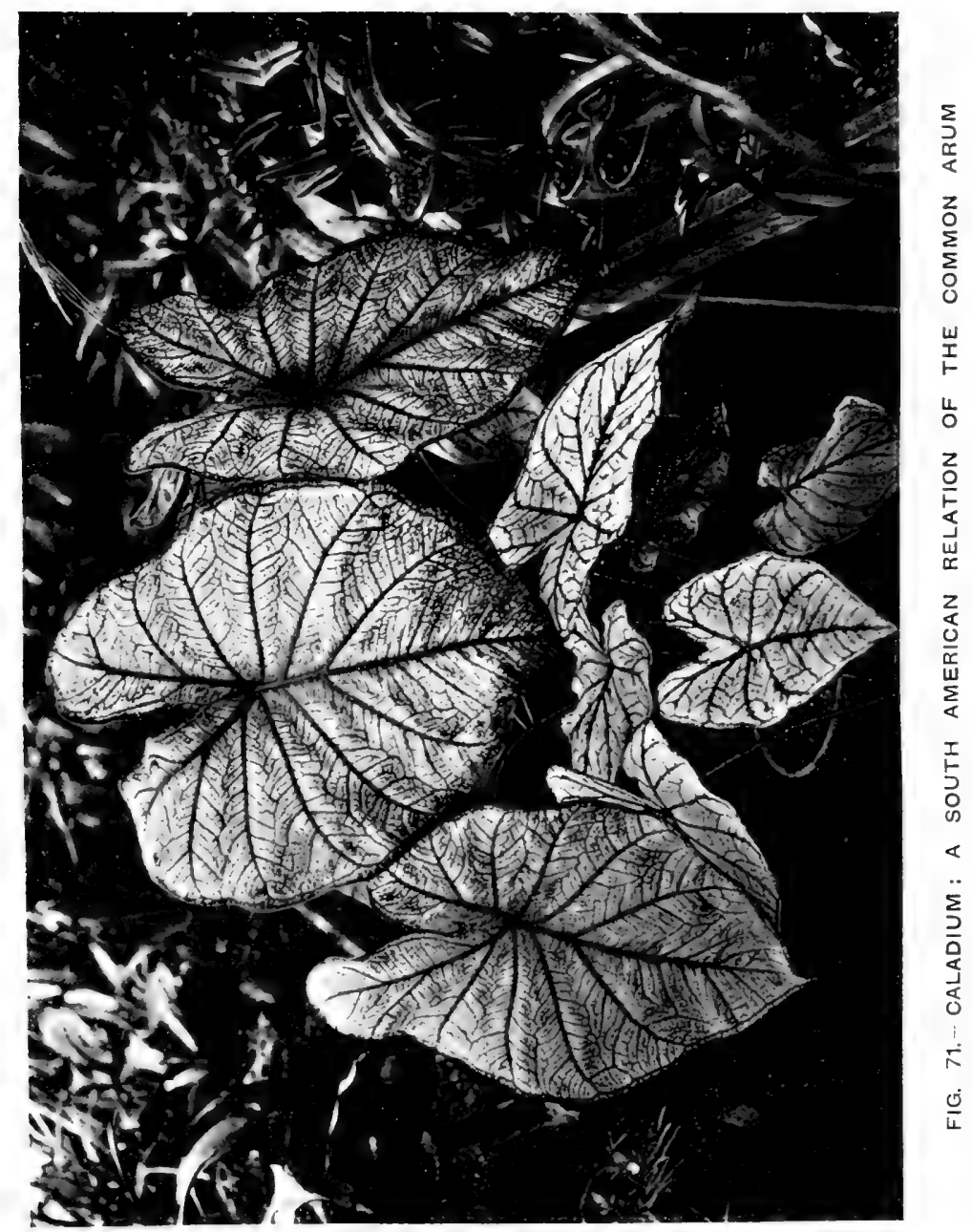


PLATE 49

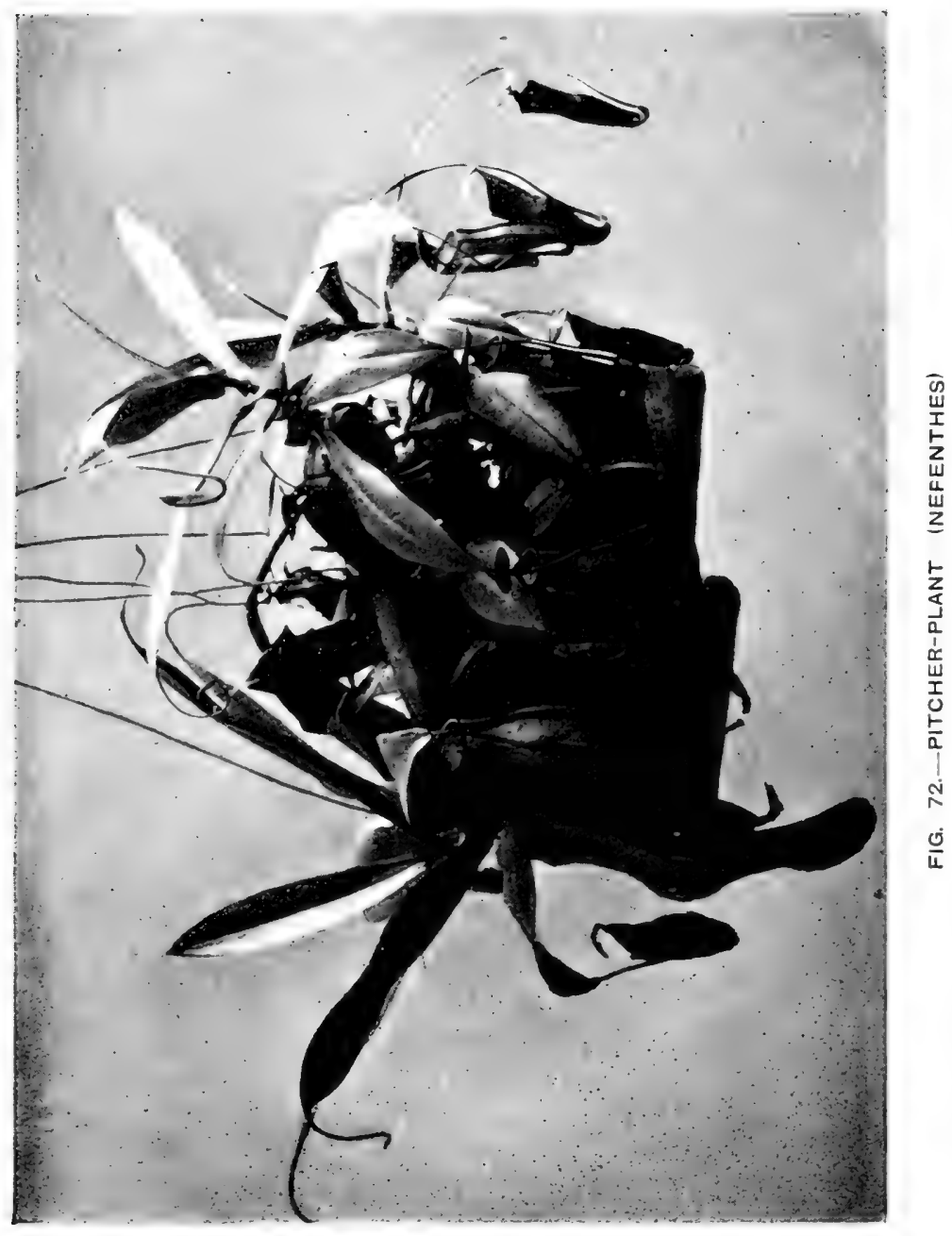


while the habitat of this giant relative is the tropics, by the side of the mighty Amazon, and the numerous lakes formed from the world's largest river.

Another wonderful example of adaptation of leaves to suit particular circumstances is shown in the curious and interesting Pitcher-plant (Nepenthes), of Indo-Malaysia (Fig. 72, Plate 49). These plants grow in boggy soils, where nitrogenous food is difficult to obtain: the soil not being able to supply the wants of the plant in this direction, the plant has to seek elsewhere. So we find the leaves developing at their ends curious pitchers $0^{*}$ vessels, the interior walls of which are lined with glands which secrete a powerful digestive fluid.

Around the mouths of these pitchers a sticky, sweet substance is secreted as a bait to lure flies and other insects into che interior, from which they cannot return wing to recurved spines forming a barrier. cinally, such entrapped insects become exhau,ced, and are drowned in the liquid, their substance being then absorbed into the plant tissues. Thus the pitcher-plants obtain their nitrogenous food, and make up for the natural deficiency of the soil.

Still more novel is the epiphyte orchid shown in Fig. 73 (Plate 50). Here we have a plant that seems to possess quite original ideas as to how it should develop-which, in fact, seems almost to have reversed all the normal conditions that govern plant life. Its roots, on a piece of dry bark, spread, it will be seen, in the air, instead 


\section{LIFE HISTORIES OF FAMILIAR PLANTS}

of into the soil as do ordinary roots. The plant requires little or no moisture other than that provided by the atmosphere, and flourishes well on the piece of bark to which it clings. Then, as if to excel these novel efforts, it grows upside down, pointing its leaves towards the ground with its roots and bulbs turned upwards. If its position is reversed to that of a normal plant, it soon readjusts itself to its topsy-turvy attitude, and in this position flowers and produces its seeds. This orchid is known by the name Cattleya citrina and hails from Mexico; but what benefits it derives from its novel manœuvres the plant seems to understand best.

In its natural habitat it grows adhering to the bark on the branches of trees and sometimes to rocks, and probably by turning down its foliage and flowers in this unusual fashion, it derives shade beneath the boughs or the overhanging rocks. Again (as another suggestion), the plant seems wonderfully adapted for throwing off water. Water poured on from above is immediately conducted to the ground; the flower refuses water in the same manner.

Now these orchids, like the cacti, being subjected to torrential rains alternating with long periods of drought, their thick and fleshy leaves-held more or less closely together-retain water within their tissues and bulbs, while the roots are continually absorbing moisture from the atmosphere. Thus the dry season is met. When the wet period sets in, seeing that the plant is not rooted in the soil, 
PLATE 50

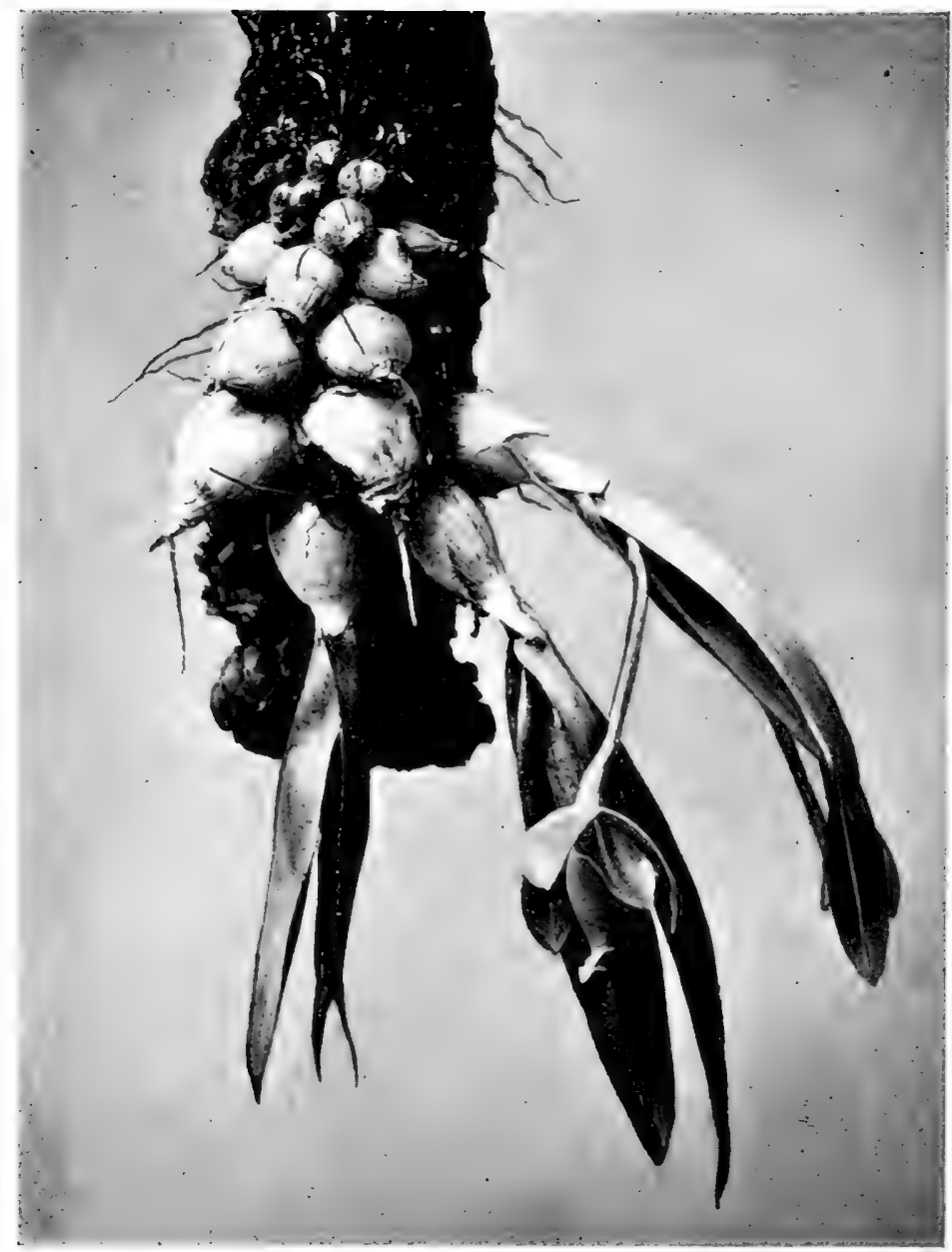

FIG. 73. -AN ORCHID (Cattleya citrina) THAT GROWS UPSIDE DOWN 


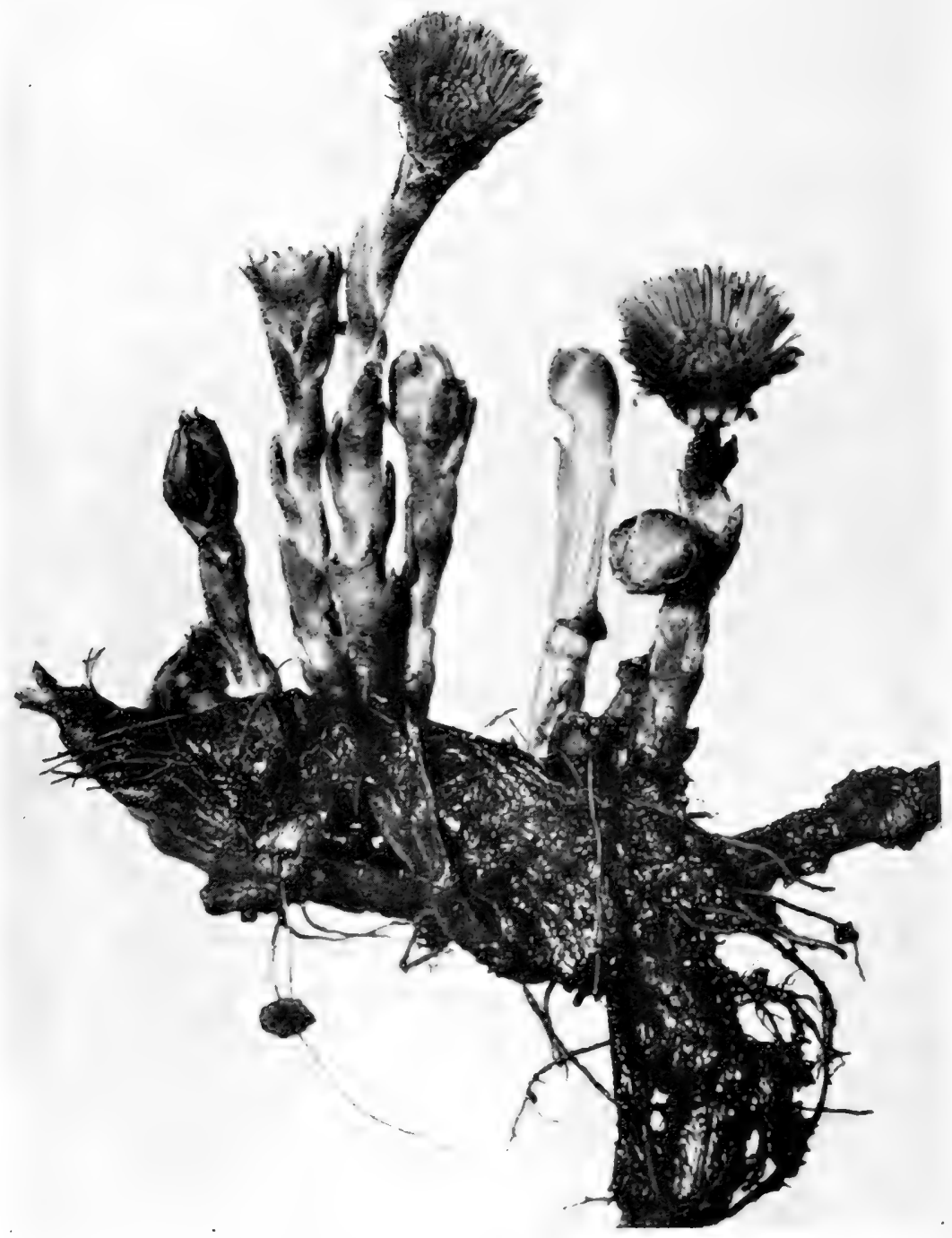

FIG. 74-THE COLTSFOOT DEVELOPS ITS STEM UNDERGROUND IN A HORIZONTAL POSITION 
it can derive no advantages from holding upright its leaves and flowers, indeed in heavy rain it would probably get them seriously damaged; a moist atmosphere is the plant's greatest need, and, consequently, the water is quickly conducted earthwards. From the earth the water rises as aqueous vapour, in which form it becomes of service to the plant.

That, I think, is what I can read from the appearance of this very original orchid plant. I may, however, be altogether wrong, judging it as I do within its present greenhouse home. To understand really the meaning of all its novel characteristics, the plant should be studied in its native haunts ; also, its past history, external conditions, and natural foes would all need consideration. In any case, the business of the orchid is to produce its flowers and seeds, and this inverted position undoubtedly suits its purpose best, just as the curious pitchers of the pitcherplants, the giant leaves of the caladium, and the spiny stems of the cacti best meet the needs of their own plants. 


\section{CHAPTER IX}

\section{THE COLTSFOOT (Tussilago Farfara)}

My friend the farmer has just been giving me some strong opinions about the coltsfoot. $\mathrm{He}$ is bent on warfare. Armed with an instructive leaflet, issued by the British Board of Agriculture and Fisheries, supplying details as to the methods of attack, he is determined to spud and to hoe, to drain, and to fertilise the land, until not a single coltsfoot dare show its face either as a flower or leaf. How far he will succeed in his deadly purpose I am not prepared to say, but I do know that this is a most wily enemy against which he has taken up the cudgels. Although I dare not hint at such a thing to the farmer, personally, I must confess that I am on the side of the enemy. I cannot help but admire the unconscious, but nevertheless artful, moves and tactics adopted by the coltsfoot weed in the course of its evolution. But then, you see, I am only a rambling naturalist (an aimless but harmless person in the farmer's opinion, I feel sure). Were I a farmer, I should doubtless view the coltsfoot with different eyes.

In the pitched battle that is now to be fought the coltsfoot has already made the first move. Although it is only the first of February, the yellow flower-heads are starred about the bare soil 106 


\section{THE COLTSFOOT}

like miniature fairy lights; no other plants have yet dared to venture so far. The farmer has gone off to consider further his plans of attack, but, unless he lays down his leaflet and gets to work quickly, the coltsfoot will have delivered a very successful assault. Every one of those ripe flowerheads is to-day fully opened; for the weather is fine, and fine weather, so early in the year, means a great deal to the coltsfoot. A few fine days at the beginning of February will insure the sowing of its seeds by the end of the month--long before most plants have awakened from their winter sleep. And at the business of disseminating its offspring, the coltsfoot probably stands unexcelled.

The coltsfoot is one of the most successful, and one of the most enterprising, weeds of my acquaintance. In the course of its development it has had to " rough it." There is nothing fastidious about it; its success is plainly due to hard work. Given the poorest and heaviest of clay soils, it goes vigorously to work, and soon is flourishing; abundant moisture is its one and only demand. From the surface of the damp and chilly clay, to which its ancestors in their struggle for existence have been driven, it now proudly holds up its flower-heads.

Few plants can attack it in its stronghold, for a hardy constitution is needed in these cold, retentive soils. The coltsfoot itself, however, often encroaches on the domains of other plants, especially in moist situations, and usually at the 


\section{LIFE HISTORIES OF FAMILIAR PLANTS}

expense of the plants among which it finds itself; for it throws up its flower-heads and scatters its seeds over their ground while they have scarcely peeped from the soil, and then, when its large and clumsy leaves appear, its weaker neighbours get sadly jostled. Standing room and the all-important sunlight daily become less for them until at last the coltsfoot reigns supreme.

How came it to possess such power? Growing, as the coltsfoot does, upon soil so poor that the wonder is it could support any plant, we should expect to find a weakling in such a situation rather than a strong, luxuriant plant with highly developed characteristics for making its way in the world. In the first place, however, we must not overlook the fact that, although the coltsfoot seeks humble quarters, yet it is not by any means a humble plant. It is of the Composite class, belonging to that dominant family of plants of which the field daisy and the wild camomile (see Chapter I.) are members; a family that, as I have previously pointed out, is the most extensive and most progressive amongst flowering plants. The coltsfoot's "credentials, therefore, are good; and the fact that it adopts a poor soil where other plants could not eke out an existence, is only another manifestation of the progressive characteristics of the family to which it belongs.

It so happens that poor, stiff soils lack certain nitrogenous materials which are more or less necessary to all living plants. Now the coltsfoot has so adapted its assimilative processes that it I08 


\section{THE COLTSFOOT}

can carry on its living functions with a minimum of such material. Thus it can pioneer new ground -ground, too, for which there is little or no competition. Also, the fact that a plant builds its structure and living materials in considerable part from the atmosphere and from water, and not from the soil, has to be remembered.

The nitrogenous and mineral matters derived from the soil are, it is true, important in carrying on the living processes, but when the water has been driven off in the substance of a leaf (or if preferred, of a great tree trunk), only some six or seven per cent. by weight would represent their value. The bulk of their dry weight, therefore, is manufactured from the atmosphere, from materials assimilated by the leaves.

Seeing that the soil is only important from the nitrogenous and mineral standpoint, it is clear that if the coltsfoot could only surmount the difficulty of carrying on its physiological processes with a minimum supply of nitrogenous and mineral material, it would then be able to go on building its structure in its poor soil just as well as those plants which grow in more select situations. Indeed, I will endeavour presently to show that it derives advantages from being upon such ground; but, so as to lead up naturally to what I have to point out, we may glance at the coltsfoot's method of procedure as it develops.

Here on this first day of February it holds up its flower-heads, inviting by their golden hues the earliest insects that are abroad. But how came it 


\section{LIFE HISTORIES OF FAMILIAR PLANTS}

to be so early in the field? Well, you can depend upon it, that such early blossoms are the product of a previous season's growth. After some considerable difficulty, I have grubbed up with my stick a piece of a plant which is shown in Fig. 74 (Plate 5I). A glance at this photograph explains the whole matter. The coltsfoot develops its main stem under the ground in a horizontal position, where it branches in all directions. At frequent intervals it does more than this, it sends down a special staple branch in a vertical direction, which sometimes extends three or four feet into the earth. Thus it becomes a network of branches firmly staked in the earth at intervals.

That is the coltsfoot's method of meeting the farmer when he comes hoeing and spudding. These underground branches contain rich stores of starches and building materials, so that immediately the temperature begins to rise, the flowering stems whose buds spring from the upper side of the underground stems, begin to peep above the soil. Observe them as they appear. Each stem is clothed with scales provided with woolly hairs to give warmth and throw off moisture. Also, the scales are of a purplish colour; which colouring, as I have pointed out in Chapter IV., is especially active in absorbing all the available heat of the scanty sunshine of the early months of the year. One after another the scaly stems sprout through the soil, and at the first glimpse of sunshine they suddenly grow taller, and then the summit of each one reveals a fringed yellow head. 


\section{THE COLTSFOOT}

The head of minute flowers, at first glance, is not unlike a dandelion, but you have only to look at it closely for a minute to see that it is really more like a daisy with several rows of fringe-like yellow ray florets. Of the numerous florets themselves I need say but little, as these are very similar to those of the wild camomile described in Chapter I. Like the last-mentioned plant, the outer ray florets are female, possessing no stamens or pollen-producing organs. The inner disk ones, however, produce both ovary and stamens, also like those of the camomile; but although they possess an ovary, they rarely, if ever, mature their seeds; the ray florets alone ripening their seeds.

This feature of an existing ovary losing its power of maturing its seeds is interesting, as it shows how the coltsfoot is struggling to insure that every one of its seed-producing flowers shall be cross-fertilised. The stigmas of the ray florets come to maturity several days before the pollen of the disk florets ripens, hence they receive pollen brought by insects from neighbouring blossoms.

There was always a risk, however, that some of the pollen from the disk florets might be conveyed to the stigmas; at least, if not to the stigma of the same flower, to stigmas in the same head of flowers; but the suppression of the functions or the ovaries of the disk florets completely prevents this, for, seeing that the ray florets are usually fertilised before the pollen on the same flower appears, it follows that the pollen can only be 


\section{LIFE HISTORIES OF FAMILIAR PIAANTS}

used for fertilising the stigmas in other flowerheads. In this way not only is cross-fertilisation of the seed-producing ray florets effected, but they are assured of receiving pollen from a distinct flower-head; and this is as likely as not to be brought from an entirely different plant, which would give still more vigour to the effects of such cross-fertilisation.

The coltsfoot guards its pollen almost as a bird does its eggs. When at first the flower stem peeps above the soil, its head droops while the stem elongates. Then, suddenly, the head becomes erect and the florets are exposed; but only in response to an hour of tempting sunshine; at night, or before if a storm approaches, each flowerhead quickly closes. At the time of the year when the coltsfoot shows its flowers it has severely cold nights to contend with, and continually changing weather, together with heavy rains and perhaps snow, and its pollen and maturing seeds take considerable risks.

Nevertheless, the remote ancestors of the coltsfoot struggled through these trying vicissitudes for many ages, from generation to generation, ever adapting their structures, by bitter experience, how best to overcome their greatest difficulties. To-day we find them at a victorious stage of their history; we see them when they have stolen ahead of many of their keenest competitors, and have become established as a strong and dominant species. So it occurs that in March and April, just when most plants are 


\section{THE COLTSFOOT}

arranging to begin business, the coltsfoot is exhibiting its white fluffy heads of seeds above the tops of the developing grasses and other plants. Not uncommonly these are mistaken for the heads of dandelion seeds, but, although the dandelion is early with its blooms and seeds, the coltsfoot has generally scattered its seeds far and wide on the strong winds before the dandelion has well put forth its flowers.

After fertilisation, the little fruit or "seed" at the base of each floret rapidly ripens, and on its apex appears a hairy pappus, similar to that of the thistle. In the early stages of the coltsfoot's evolution, this fluffy head-gear was the calyx or green outer part which surrounded the petals of the little flower, but since the numerous flowers have become crowded together into one head, a calyx for each is no longer needed; hence a new function has been found for the obsolete calyx, and it has been slowly modified into the hairy pappus that lifts the little fruit on to the wings of the wind, and thus it is often carried for many miles into fields and pastures new, where the seed can germinate and the young plant flourish.

So it frequently occurs that on a newly-made railway cutting, or on fresh-turned soil, one of the first plants that makes its appearance is the coltsfoot; for its seeds must have an open space in which to germinate and the leaves of the young seedlings must have room to spread out.

Although we have followed the development of the coltsfoot from its first appearance above the 
soil early in the year until it has scattered its seeds, never a sign of a leaf have we seen ; nevertheless, the coltsfoot produces leaves, and leaves, too, of a most conspicuous character.

The underground stem, or rootstock, of the coltsfoot by no means exhausts its resources when it produces its flowering branches. No sooner do the seeds begin to ripen than other buds begin to develop, and presently these also peep through the soil. Some two months later the ground where the coltsfoot's flower-heads appeared, will be more or less completely occupied with a mass of broad and angular leaves (Fig. 75, Plate 52). The thought occurs to few people that these leaves are those of the familiar coltsfoot, for the simple reason, that in the ordinary way, we expect flowers to develop with, and amongst the leaves. So these mysterious leaves appear and make a bold show, but no flowers are forthcoming. When they have died down again, and winter has removed every trace of them, the yellow stars of the coltsfoot again become conspicuous about the surface of the bare soil.

Thus, the summer foliage and the flower-heads of early spring alternate; and a little investigation below ground will clearly show that these obtrusive leaves originate from the same rootstocks as the coltsfoot's flower-heads.

It is interesting to observe how the leaves of the coltsfoot thrust their way amongst the grasses and other plants into the sunlight ; which feature I have endeavoured to illustrate in Fig. 76 (Plate 53). Their curiously-angled edges assist in this opera- 


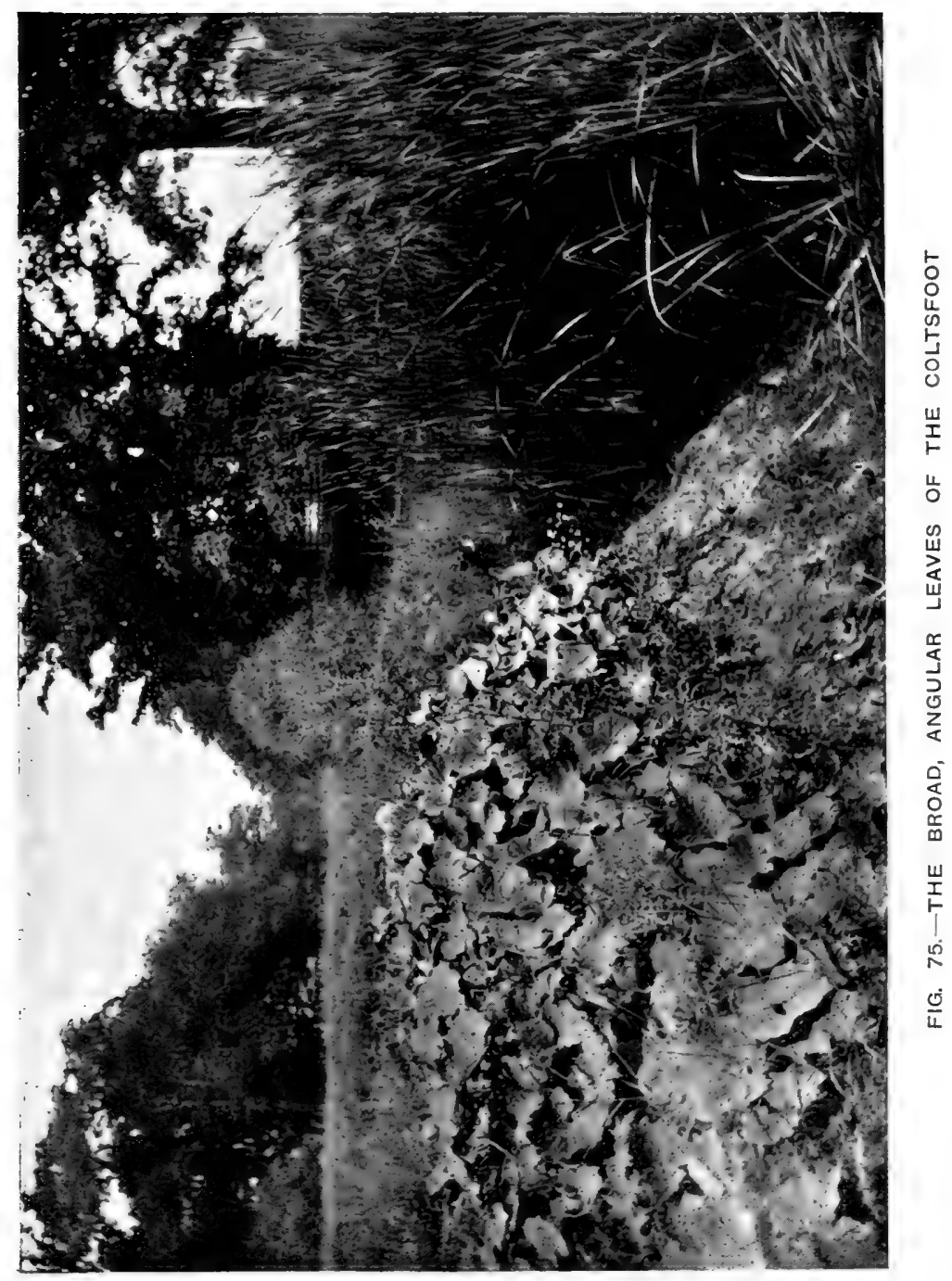




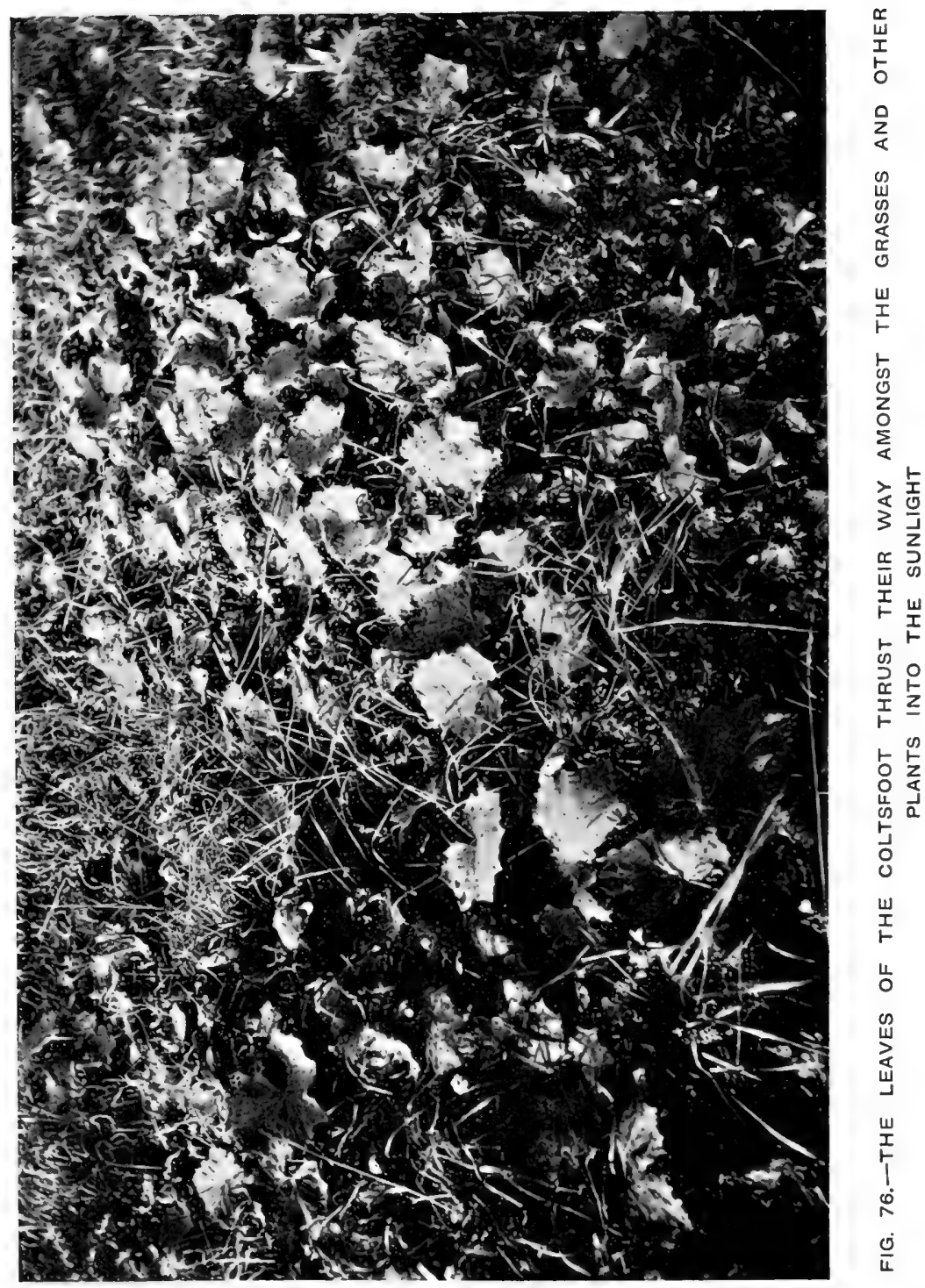




\section{THE COLTSFOOT}

ation; once the leaf gets clear, it spreads out its broad surface (sometimes eight inches across) to the sunlight, and there it absorbs carbon dioxide, or more familiarly, carbonic acid gas, from the atmosphere. The carbon derived from this impure gas is then chemically united with the watery sap supplied from the soil by the roots, the ultimate product of this combination being energy-yielding starches, oils, and similar materials. These lifegiving products are at once conveyed below ground and stored in the rootstock, and there are held in reserve until early in the next year, when they will be utilised in the production of flower and leaf shoots. Thus the work of the summer foliage provides the early growth of the next season.

Now the building of these life-giving materials from inert carbonic acid gas, or carbon dioxide and water, can only take place in the tissues of the green leaves under the influence of sunlight. Hence we see why the coltsfoot requires large and expansive leaves, and we account for their persistence in monopolising all the available sunlight. Flowering stems bearing rich pollen, and seeds containing starches and oils, cannot be produced so early in the season as those of the coltsfoot without a large and rich reserve of material; and the wily coltsfoot has learnt its lesson well. Also, by selecting ground on which other plants find it difficult to thrive, the coltsfoot can spread out its leaves in unrestricted exposure to the sun's rays; hence their large size.

Of plants which grow in open spaces where 


\section{LIFE HISTORIES OF FAMILIAR PLANTS}

competition for sunlight is small, we find the leaves large and broad. Water-lilies present a striking instance (Fig. II5, Plate 83). In the middle of the open river there is ample room, and consequently the leaves of the water-lilies can spread out freely to the air and sunlight, and so they become large and almost circular; but in crowded places such as pastures and thickets, where the competition for light and air is keen, the leaves are usually much divided, as in buttercups and in the wild camomile already discussed.

Therefore the broad leaves of the coltsfoot are the best suited and most economical for the bare railway cuttings and the poor soils favoured by the plant. Note, too, how the under side of each leaf is felted with a thick covering of woolly hairs. By the river bank and in the clay valleys, where the coltsfoot is so often found, the leaves are much subjected to mist and vapour from the heavy. dews of night and morning, and it is on the under side of them that the tiny " breathing-pores," through which the plant effects its interchange of gases with the atmosphere, are found. The leaves could not carry on their functions of starch manufacture if these tiny pores were allowed to get clogged; so it happens that a thick felting of hairs protects their lower surface, and this throws oft water like the proverbial duck's back. Such leaves are common to plants that grow in moist quarters ; some willows, alders, thistles, and the common meadow-sweet exhibit a like feature.

Such, then, is a brief outline of the curious I 16 


\section{THE COLTSFOOT}

habits and quaint details of structure of the familiar coltsfoot. It is one of the commonest of weeds, and this point alone emphasises the fact that it is a successful species, a species that is established and can hold its own against all comers. My friend, the farmer, though, is on its track: he is hoeing and spudding for all he is worth. So he may, but the coltsfoot will not give in ; it will fight for and secure its corner, as it has ever done. The farmer is no new enemy; the coltsfoot has fought him many times before; it knows his strategy well. Its alternating periods for flowering and leafing, and its deep penetrating rootstock are counter-movements against his persistent attacks. But even should he once succeed in eradicating the coltsfoot from his plot, his victory is but for the moment. When the ground is newly-turned the coltsfoot will once more return from the distant railway cutting on its hairy wings, and remind him that the battle has not ended, and also that, if he is determined to monopolise the land, he must fight for it. 


\section{CHAPTER X}

THE CATKINS OF THE WILLOW (Salix Caprea)

THERE is no more familiar hedgerow ornament in early spring than the blooms of the sallow-the "palm" of the country people, who gather them at Eastertide when celebrating their religious festivals. Comparatively few, however, amongst those who pluck these quaint floral structures, that so brighten the appearance of the otherwise bare branches, possess any knowledge of their meaning and function. Now they gather the golden "palm" and again the silver, but why some blooms should be yellow, or golden, and some grey, or silver, is a point that never seems to enter the minds of most of those who seek the branches. Nevertheless, half an hour's study of the details of these blossoms will reveal some wonderfully interesting features, and give the "palm" blossoms quite a new charm; even if that charm arises only from the possession of the knowledge that we really understand what we are gathering. Therefore, assisted with pocket lens and penknife, let us endeavour to read the story of these hedgerow ornaments.

In the first place we have to recognise that these structures are the floral products of a species of willow, and have no relation with the true palms, 


$$
\mathrm{z}^{2}
$$




\section{PLATE 55}
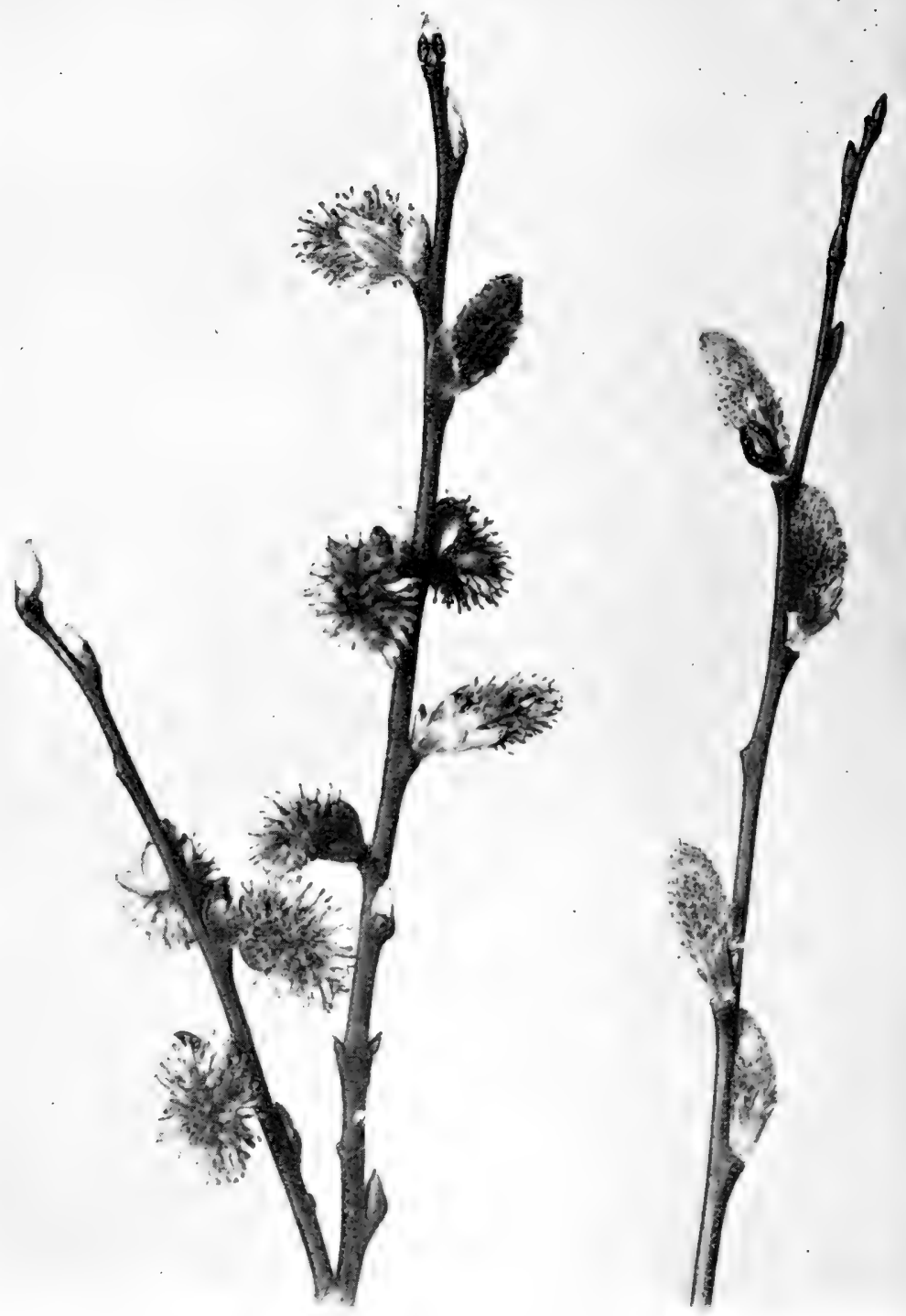

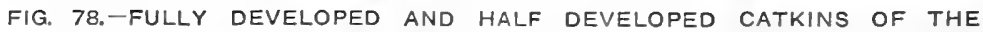
SILVER "PALM" 


\section{THE CATKINS OF THE WILLOW}

which are natives of warmer climates. Owing to their early appearance, the willow blooms have come into use at Easter ceremonies as symbolical of the palms borne before Christ on His entry into Jerusalem; hence their popular name "palm." There are at least some fifteen or sixteen species of British willows; though, for reasons which I will explain later, some botanists list a much larger number than this. The tyro in botany usually recognises some two or three species, such as the weeping willow with its pensile branches; the familiar white willow, either in its natural form as a large tree or in its deformed state with broad trunk and pollard top by the river-side; and perhaps the osier of basket-making fame, which is found in the same quarters as the last mentioned, would make a third species; the "palm" might be added as a fourth example but for the fact that, owing to its popular name, it is not ordinarily recognised as a willow. However, all the species bear an inflorescence that more or less resembles that of the "palm," or sallow; the latter, however, is conspicuous on account of its large size and the wide distribution of its species. It is the species known to the botanist as Salix Caprea, and is a familiar shrub throughout Europe and Asia, extending even to the Arctic Circle ; in Britain it is familiar to most people.

The inflorescence of the " palm " willow (shown in Figs. 77 and 78, Plates 54 and 55) is a catkin. Having dealt with the catkin form of inflorescence, I need only say that these catkins also are 


\section{LIFE HISTORIES OF FAMIIIAR PLANTS}

composed of numerous minute flowers; they differ, though, from the catkins of the hazel and those species considered in Chapter IV., in various ways. Two examples are shown in Fig. 77 (Plate 54). The one on the left is fully developed, while the one on the right has yet to complete its development. It is obvious that the example on the left is the golden or yellow "palm," and apparently the example on the right is the grey or silver. That is a point, though, to which I desire particularly to call the reader's attention.

A specimen such as that shown on the right of the picture will, if its stem is placed in water for a few days, develop into the golden or yellow form shown on the left. There are, however, some of the grey or silver forms that will never change into the yellow kind; in Fig. 78 (Plate 55), an example is shown. Here, again, on the left a fully-developed specimen is figured and, on the right, one at an earlier stage. Another point that should be observed is that the fully-developed silver "palm" is never found growing on the same tree as the fully-developed yellow kind. Sometimes it may appear to be so, but a little observation will show that the apparent silver "palm" is the undeveloped yellow like that on the right of Fig. 77 (Plate 54). Indeed, a glance at the examples figured in the two photographs will demonstrate that the catkins are different in form, even in their earlier stages, when they both bear a grey or silvery appearance; and yet they come of identical species. What, then, is the 


\section{THE CATKINS OF THE WILLOW}

meaning of their differences and their growing apart on distinct trees?

To answer that question we have to examine a catkin of each in detail. Taking, first, one of the yellow examples, we cut it through with a sharp penknife, and then, assisted by a pocket magnifier, dissect one of the tiny flowers from the crowded mass. In the example on the left of Fig. 79 (Plate 56), the little flower is shown as it appears when magnified. It only needs a glance to see that it consists of a scale clothed with silky hairs and two stamens with long filaments, or stalks ; there is also a little gland at the base of the stamens, of which I will speak later. The yellow catkin, then, consists of hundreds of tiny, simple male flowers all crowded together and each composed of a scale and two yellow-headed stamens-for it is the yellow heads of the stamens and the yellow pollen that falls from them that gives the golden colour to the catkin.

Now, in a similar manner we examine the silver catkin. On the right of Fig. 79 (Plate 56 ) is shown one of the little flowers. It is obvious that this is entirely different from the flower of the yellow catkin ; indeed, it consists of an ovary or seedproducing part and a hairy scale. There are no yellow-headed stamens or yellow pollen in this case-nothing but the grey or silvery hairs that clothe the ovary and the protective scale. It is plain, therefore, that the silver catkins produce only female flowers.

When dealing with catkins in Chapter IV., 
I then pointed out how the male and female catkins grew apart, so that the wind might effect cross-pollination by blowing the pollen from the male catkins to the stigmas of the female. Now we see in the case of the willows this device has been carried much farther; their catkins grow on distinct trees, so that not only is cross-pollination effected, but it becomes impossible for the female flowers to be fertilised from the pollen of male flowers growing on the same tree. Thus a still more perfect cross-fertilisation is eventually brought about.

I have previously mentioned that at the base of the stamens in each male flower there is a tiny gland; also at the base of the ovary in each female flower is found a similar organ. These glands produce very profusely a colourless honey or nectar; and the honey smell is very strong when the flowers are maturing. Consequently, numerous honey and wild bees are continually visiting the flowers throughout the day, becoming more or less covered with yellow pollen from the stamens of the male catkins; and this they convey to the female stigmas on distant trees. Also, this same sweet smell of the honey attracts numerous species of moths by night; indeed, visiting the sallow blooms with lantern and "killing-bottle" is a very profitable occupation for the entomologist during spring nights ; the moths likewise visit both male and female trees.

Now catkins are a form of inflorescence specially adapted for wind-pollination. How 


\section{THE CATKINS OF THE WILLOW}

comes it, then, that the flowers of the willow catkins secrete nectar to attract insects? Undoubtedly the willows were once wind-fertilised, as the complete absence of a corolla or floral envelope and the simple structure of their flowers plainly indicate ; but, probably owing to bees and other insects showing great appreciation for their pollen and frequently visiting their flowers in search of it, the flowers have again produced nectar. I say " again produced nectar" advisedly, because I have, in an earlier chapter, already expressed the opinion that the remote ancestors of wind-fertilised flowers once wooed insects with nectar and coloured floral parts, but that they had now changed their habit; therefore, I suggest that the willows have again returned to insect-fertilisation.

However, having once lost their petals and other floral parts, they could not again reproduce these. Nectar has once more been provided, but not necessarily from the same nectaries that the original insect-fertilised flowers possessed; most likely these nectaries are an entirely new and much later development, evolved as a means of saving the pollen that was being carried away by the bees for their own use; for nectar is cheaper to produce than rich pollen, and probably owes its origin generally to that reason. The coloured envelopes having been aborted, all the male flowers can do in the colour direction is to make their stamens as attractive as possible; and the female flowers can only develop the silky hairs 


\section{LIFE HISTORIES OF FAMILIAR PLANTS}

that clothe their ovaries and scales; thus the attractive appearance of these catkins.

Seeing that the minute flowers of the willow catkins have no trace of a corolla, it may be asked what reason there is for supposing that they once had one. With most wind-fertilised flowers (and especially in that great wind-fertilised family the grasses, of which I will say more in a future chapter) there may be found traces of the lost parts of the flowers. In the willows it happens that such traces are very small, but in their near relations the poplars there is a distinct little cup around the base of the ten or twenty stamens in each male flower, and also around the ovary in each female flower. Even in the willows themselves some species produce three stamens and others five, and they vary in other details in different species. Such facts all tend to show that probably the flowers now bearing two stamens once had more, like the poplars ; and it can scarcely be termed "begging the question" to assume that they might also originally have had a similar cuplike perianth around their bases, but that it has now disappeared.

Assuming as correct the suggestion made above, viz., that the bees visited the catkins in search of pollen, and that nectar was provided to check their thievery, another question then arises: How came the flowers of the female catkins to produce nectar? The latter had no pollen to lose, and certainly the bees would not trouble to visit them simply to fertilise their stigmas. Now, the answer 


\section{THE CATKINS OF THE WILLOW}

to that question is, most probably, that at the time the tendency to produce nectar originated, the sexes of these flowers did not grow on separate trees. I have already shown in the case of the sycamore how flowers of one sex are evolved from the bisexual form, and how unisexual and bisexual forms may be found together on the same tree; and likewise in the case of the ash flowers.

Therefore, should the tendency to develop nectar occur while the unisexual catkins were growing together on the same tree, the flowers of each would naturally develop similar characteristics, and so both produce nectar. However, any tendency in a tree to produce an abnormal number of female catkins would confer benefits upon its species, as many of its flowers would then have to receive pollen from another tree; which would result in a more effectual cross-fertilisation than from pollen from flowers on the same tree. And an excess of male catkins would largely prevent their pollen from being used on the females of that same tree. Therefore, encouraged by the continual visits of bees seeking pollen and nectar (which insured cross-pollination), the habit of developing their sexes on distinct trees was strengthened. Thus to-day we find them completely isolated; so much so that great confusion has prevailed amongst botanists in enumerating the species and matching their sexes, especially as many species flower before the leaves appear.

Such are some of the remarkable ups and downs experienced by the "palm" willow in 


\section{LIFE HISTORIES OF FAMILIAR PLANTS}

the course of its history, all plainly written in its silky catkins. It is true there is now scarcely any trace of its earliest period of insect-fertilisation, but the structure and arrangement of its minute flowers distinctly point to a period of wind-fertilisation, such as that of the hazel at the present day; while its honey-producing glands and the obvious visits of insects now clearly show that its habit of wind-fertilisation has become a thing of the past ; although, of course, it may be even now occasionally wind-fertilised. 

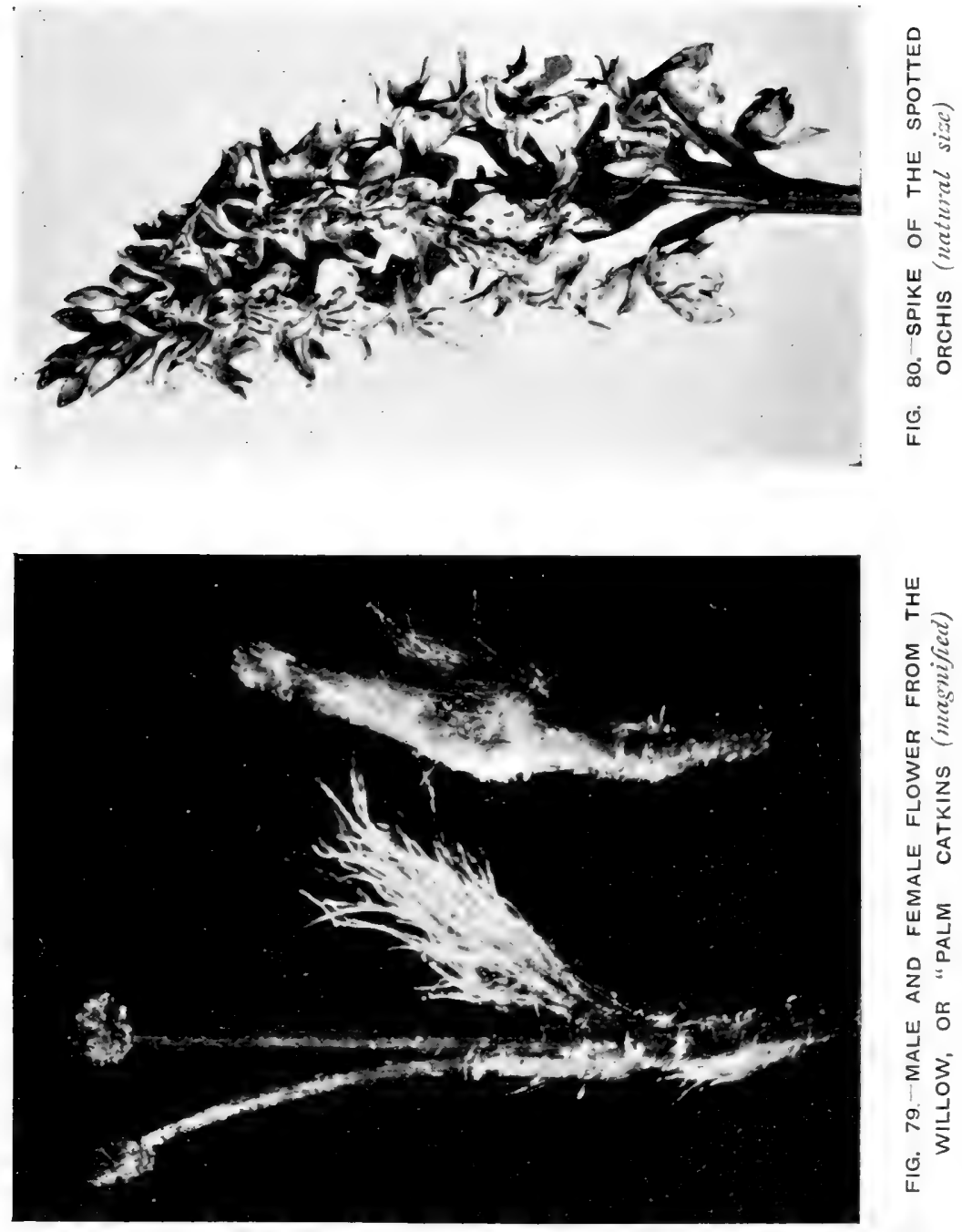
PLATE 57

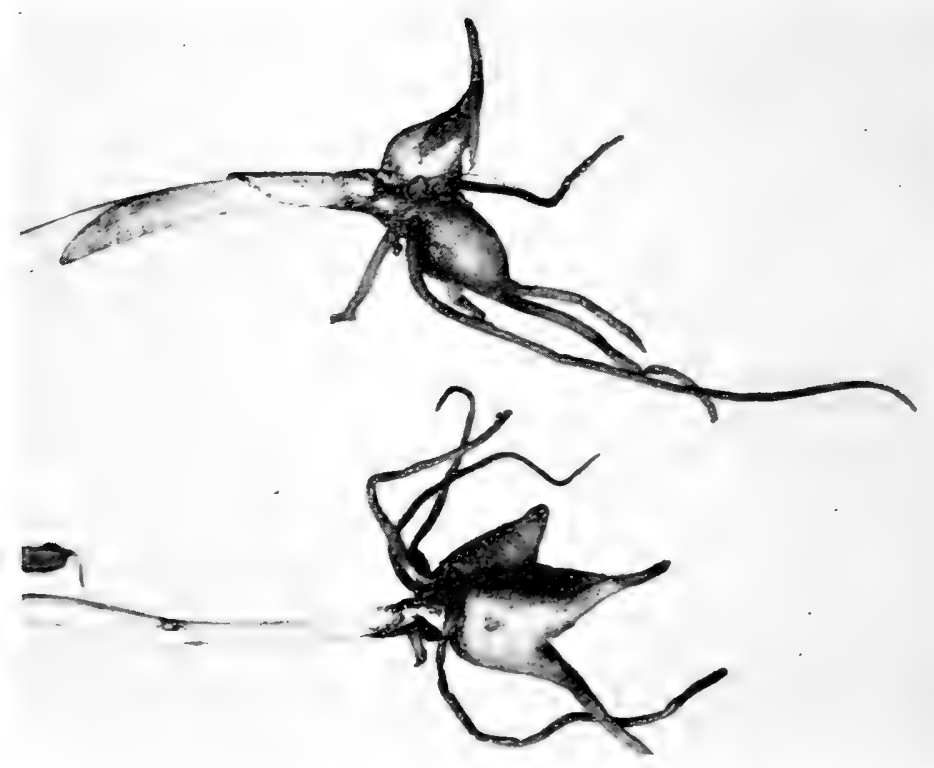

$\stackrel{W}{I}$

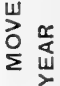

壱

웅요

แ

간

ว

ว

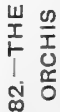

$\frac{0}{4}$

แ

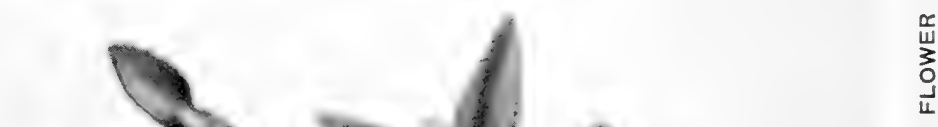

$\frac{\pi}{4}$

$\frac{\omega D}{T}$
$\frac{11}{0}$
$0 \frac{\pi}{0}$

离芦

0 음

แू

政

采岌 


\section{CHAPTER XI}

THE WILD ORCHID (Orchis maculata)

I HAVE just been working amongst my orchids, but have had to leave the work somewhat abruptly owing to an unexpected thunder-shower. It so happens that my orchids are not grown under glass ; in fact, it is quite probable that my orchid garden would astonish most of my readers if they saw it. A friend to whom I introduced this garden, remarked that it was what he should call "a lane." Now that is just what my orchid garden is-a real good, old-fashioned, Warwickshire country lane. On both sides of the rough and cart-rutted roadway there is a broad spread of green grass before the hedgerow is reached, and amongst that grass, the whole long length of the lane, throughout the year, you can always find a choice, wild flora.

The low-lying and broadest of these grassy expanses is generally a semi-submerged area, and it is there that my spotted orchids grow, for they love moist quarters. There they throw up their tall spikes of pale lilac blossoms all spotted with deeper purple. In Fig. 80 (Plate 56) one of these spikes of bloom is shown of natural size. In the mass the little flowers make a show, but individually, they are insignificant. Their insignificance, however, is only a matter of size; 


\section{LIFE HISTORIES OF FAMIIIAR PLANTS}

structurally considered, each is as much an orchid as the choice odontoglossum, cattleya, or cypripedium of the rich cultivator. In Fig. 8I (Plate 57) this is clearly illustrated. Here is shown a magnified view of the topmost part of one of these spikes, with one flower fully opened and the lower flowers removed. So enlarged, its orchid form is readily recognised.

My work amongst the plants to-day has not been cultivation. The spotted orchid, or, to be strictly correct, orchis, needs no attention; it thrives best when left to its own resources. It has, by slow adaptation of its form and structure to the requirements of its environment, attained a marvellous degree of perfection. Indeed, when considering the curious details of its remarkable organisation, one is inclined to wonder if there can be found anything more extraordinary in the whole of the plant world. Perhaps there is nothing more extraordinary, unless it be still other species of orchids ; but as each species possesses its own novel characteristics together with the general family traits, the spotted orchis is as wonderful as any. My work to-day has been investigation into the mysteries or its existence, and I now invite my readers to share my observations.

There are the roots of this curious plant. They are well worth a little study, but it will need some considerable care to get them clear of the soil in anything like a perfect condition. Time after time the stems will break off low down in the ground without revealing any signs of the pair of 128 


\section{THE WILD ORCHID}

tubers. Fig. 82 (Plate 57) will, however, explain matters. Above the flattened and divided tubers are some strong, vermiform roots which direct their growth towards the earth's centre, and consequently exert a downward pull at the base of the stem. One result is that every year the tubers get deeper into the earth; therefore, the older the plant the greater will be the difficulty of removing it uninjured. The tubers spread out somewhat laterally and are divided into finger-like segments. Now this arrangement places the orchids amongst the most up-to-date of plants, so to speak, as regards their roots. These slender roots penetrate the soil deeply and thus sink the tubers into the earth well below the frost level, and so their rich food stores are protected from cold and aboveground enemies. Also the stem above the tubers is weak, and is readily broken at that part, so that a pull from above only results in breaking off the upper part of the plant, a loss which the roots and rich tubers will remedy in the course of time.

The tubers themselves are of peculiar interest. As is common with thrifty and advanced plants that suddenly make a bold show of bloom, the flowering spike of this wild orchis is produced at the expense of a previous season's growth. A further glance at Fig. 82 (Plate 57) will show that both the tubers of the same plant appear to be about the same size; and this arises from the fact that both plants were gathered midway in the growing season. Early in the year we should have found 


\section{LIFE HISTORIES OF FAMILIAR PLANTS}

one large tuber, and possibly the decayed and shrunken remains of another ; and again, as winter approaches, we should find a similar contrast. The large tuber left before winter, is that which is to supply the material for the growth of the following spring and summer. Later the leaves assimilate further material, and from this a new tuber is formed as a storehouse for the next season's growth; midway in the season we find a pair of tubers of almost equal size, but they differ in that while one is half exhausted the other is but halt formed.

This arrangement of two tubers, one for present and the other for future use, is peculiar to the orchids, and the significance of this device has not to my knowledge been observed. Now my examination of the roots of a number of these plants to-day suggests that the spotted orchis has adopted by this double organisation of its root-functions a most practical and most ingenious device. Look again at Fig. 82 (Plate 57), and note that each tuber takes opposite directions. Glance at the example on the left of the photograph, and observe the pale-coloured conical bud that appears at the apex of the tuber against the stem. From that bud will come the main stem of next season's growth.

Now it is obvious that, if the newly-formed tuber directs its course in the opposite direction to the old one, when the latter perishes, together with the stem, the new tuber is left alone on new ground. Then, in due course, when I 30 


\section{THE WILD ORCHID}

growth begins, the new stem slowly uprights itself, and from the top of the tuber new slender roots are formed which eventually fix the tuber in its position. Thus, each season the orchis exploits new ground, and the stem, therefore, begins to grow under the most favourable conditions; indeed, the plant has in this manner accomplished by its own device what is equivalent to a "rotation of crops," the importance of which the farmer fully knows.

This well-arranged root scheme, then, not only provides the plant with water and mineral substances, but also serves to protect it from frost and animal attacks; supplies it with a storehouse of food material for early growth the following season, and withal moves the plant each year into new quarters. With purposes so perfectly arranged for at the foundation, we might naturally anticipate other complex structures as the outcome of such adaptations ; and we are not disappointed.

When the spring sunlight begins to make its power felt, the shoot at the summit of the tuber pushes through the soil and quickly unfolds its quaint, lance-shaped leaves. Many are the half hours during which I have puzzled over those leaves. Striking and mysterious are they in the extreme. They are smooth, glossy, deep olive green, and spotted with stripes and dots of a dark brown pigment; and it is these curious brown markings that make them so mysterious. Their function has always been an insoluble problem; undoubtedly these conspicuous spots have a definite 


\section{LIFE HISTORIES OF FAMILIAR PLANTS}

purpose in the economy of this complex and advanced plant structure, but I am not aware that any naturalist or botanist has ever offered a suggestion as to their use and meaning.

Time after time, when looking on those weird spots and trying to decipher their hidden meaning, it has seemed to me that they possessed an appearance with which I was familiar, but the explanation I was seeking persistently evaded me. To-day, I think I have caught a glimpse of their true significance. My suggestion may by some be thought absurd ; however that may be, the function of these spots remains to be explained, and I have just been forcibly impressed by what I have seen.

By the side of my moist plot where the orchids grow thickest there lies a wood, and I had just reached the edge of it, in my search for choice specimens of the plant, when I observed part of what was apparently a particularly attractive leaf resting against the fresh green of the surrounding grass. I stretched out my hand to remove some of the grass that was covering this fresh-looking plant, when instantly the leaf disappeared from view, and a moment later an adder-a rare reptile in this district-scuttled away into the hedge bottom and disappeared in the wood. That rapid glimpse of the startled reptile awakened my memory, and I was suddenly enabled to explain what, in my mind, the curious spotted leaves of the wild orchis resembled.

The exposed part of the olive body of that viper, striped and spotted with dark markings, as 
PLATE 58

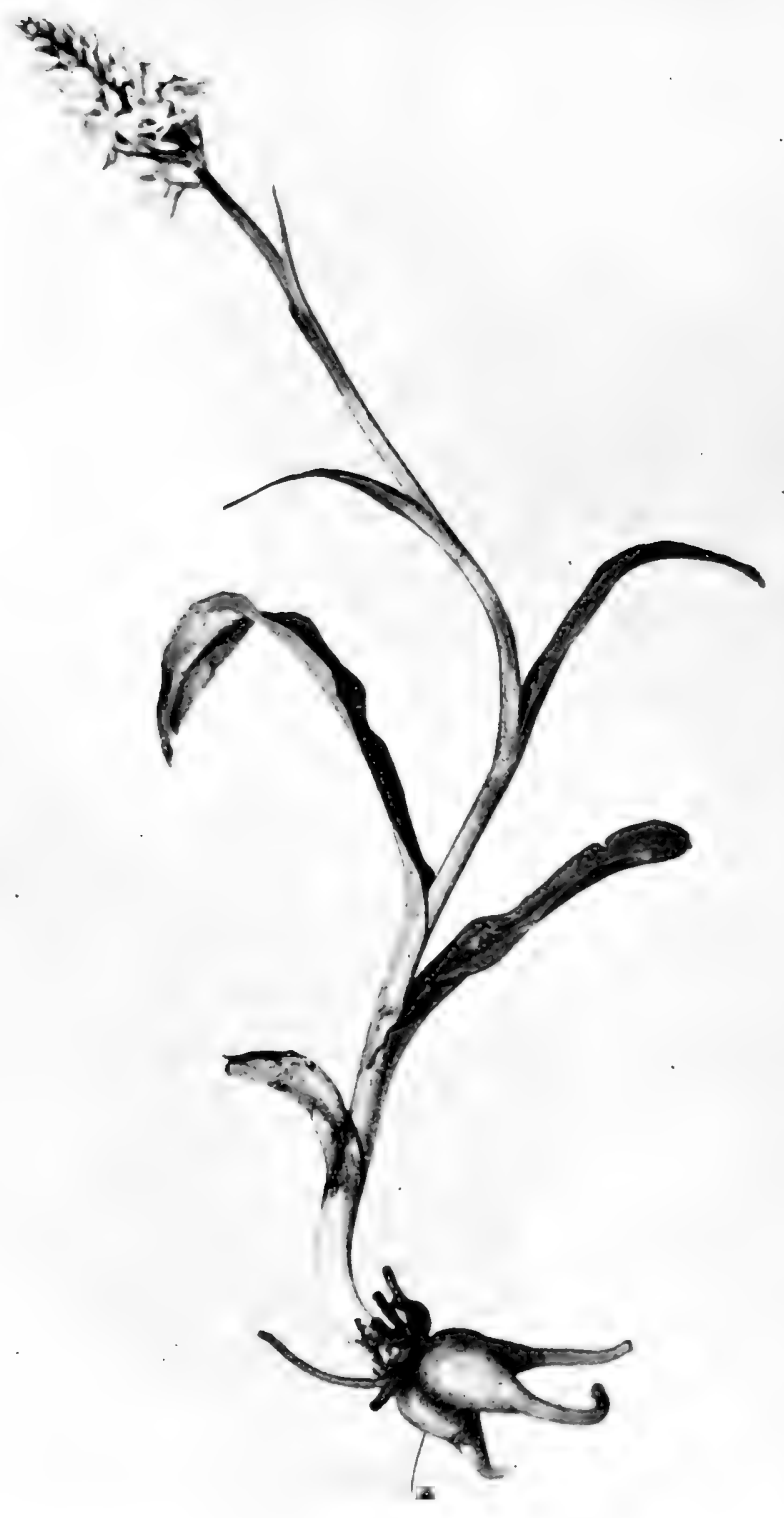

FIG. 83.-YOUNG SPOTTED ORCHIS 


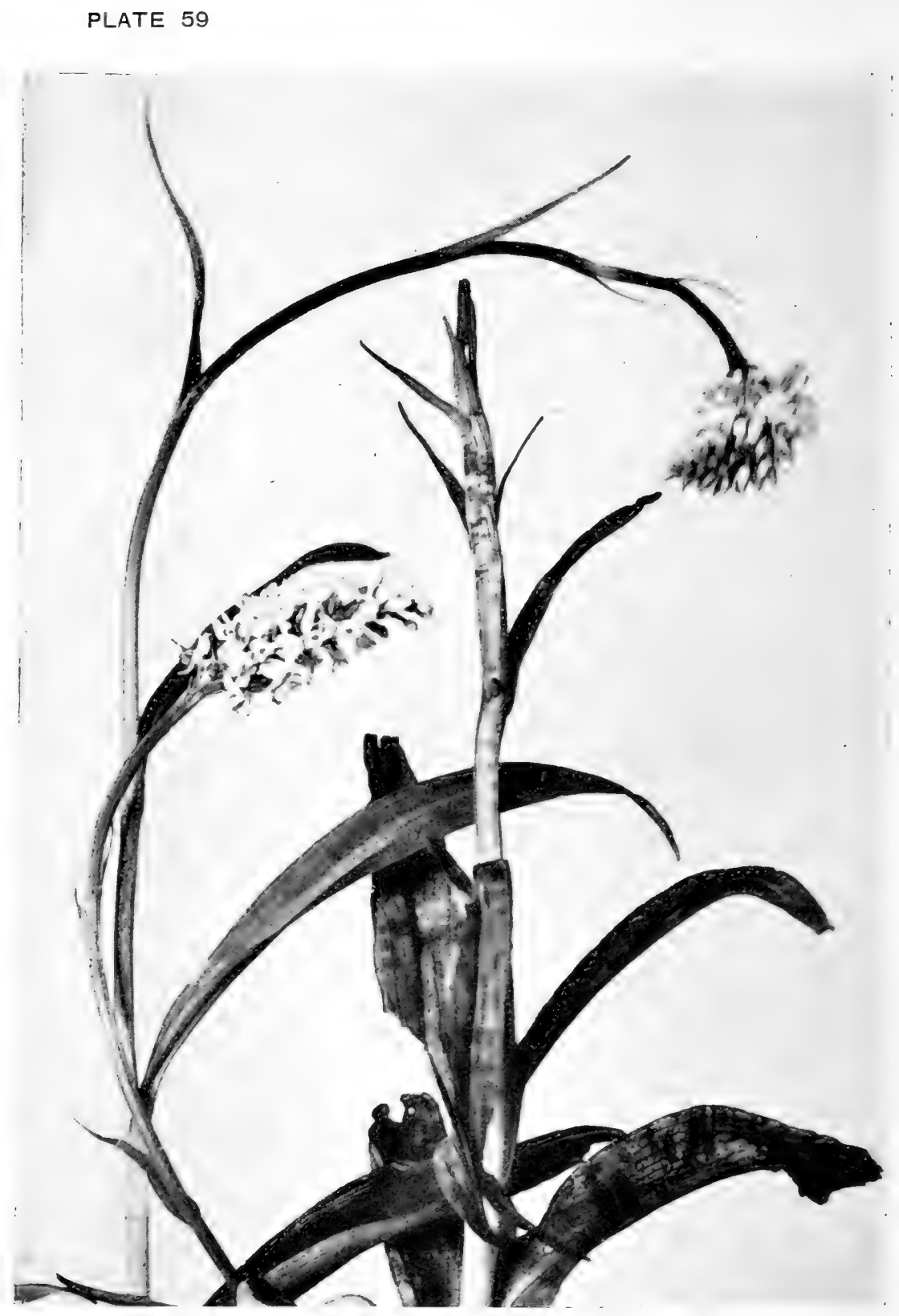

FIG. 84.-THE LEAVES OF THE ORCHIS BEAR WEIRD, BROWN SPOTS AND MARKINGS 


\section{THE WILD ORCHID}

it appeared amongst the grass, was almost identical with the appearance of some of the leaves of the orchis when similarly placed; indeed, the very curves that the leaves assumed as they poked amongst the blades of grass presented an astonishing resemblance. Look at the photograph of the young plant in Fig. 83 (Plate 58), and carefully note how the leaves are arranged to spread out in different directions, and also how each leaf bends over at the end and exposes its upper and spotted surface. The curving of the leaves and their spotted appearance are better shown in Fig. 84 (Plate 59), although the latter feature is difficult to illustrate by means of the camera, as the deep green and brown make little contrast on the sensitive plate.

After noting these things go a step farther and look at one of these orchis plants from above as it grows amongst the thick grass. You will then get only partial glimpses of its leaves, especially of those parts where the spots are most conspicuous, and particularly is this so before the flowers appear. Remember, too, that this is how grazing animals would view the plant. Now, grazing animals doubtless possess a much better acquaintance with snakes and similar. reptiles, and also with amphibians, such as frogs, toads, and newts, than man does. In the course of their daily feeding amongst the herbage no doubt they frequently meet with them, and especially in districts where these creatures are abundant. It follows, therefore, that they naturally avoid them. My reader will now, 


\section{LIFE HISTORIES OF FAMILIAR PLANTS}

of course, see my point; if the leaves of the wild orchis present a superficial resemblance to such animals they also will be avoided.

Seeing that without its leaves the orchis could produce neither tubers nor flowers, it is obvious that; in the dangerous situations in which it grows, the leaves need the greatest possible protection. The method of protection adopted is a most novel one, but, nevertheless, one perfectly in keeping with the advanced characteristics and adaptations of this up-to-date plant.

As I have previously mentioned, to some my suggestion may seem more imaginary than real, and to such I would further say that probably this protection was once of much greater value than it is to-day, as at one time snakes and other reptiles were much more abundant than at the present time. And it is also interesting to note that some near relatives of the spotted orchis, have similar brownspotted leaves, and amongst all these spotted species examples are frequently found which are almost spotless; which fact, it may be, points to the conclusion that the plants are now losing their spots, as such protection is no longer of value to them. (See Note on p. I42.)

Again, still more advanced types of the same family group are entirely without spots. Finally, it would not be remarkable if the leaves of these plants should bear a superficial resemblance to some animal form. There are innumerable known instances of animals resembling their surroundings, and also of animals mimicking by re- 


\section{THE WILD ORCHID}

semblance other animals, as a means of protection from their enemies and as a disguise from their prey ; and conversely in the plant world we have numerous examples of plants that behave like, and mimic, animals, and in no group of plants is this feature more conspicuous than amongst the Orchid family. Even amongst British species we have the butterfly orchis, the bee orchis, the fly orchis, the spider orchis, the lizard orchis, the frog orchis, and others, all of which names have arisen from the fact of the flowers of these species suggesting a likeness to the different creatures. Sometimes the resemblance is fanciful, but, on the other hand, it is sometimes striking and difficult to explain, as in the case of the bee and the fly orchis.

Therefore, I contend it is not at all extraordinary that the leaves of the spotted orchis should bear a superficial resemblance to a reptile, especially as such a feature would assist in the preservation of the species. Indeed, I am inclined to think that my suggestion may provide some explanation of the spotted leaves of some other plants, when considered in relation to their natural environment; although the subject needs further investigation.

As I have endeavoured to show, both the roots and leaves of the spotted orchis exhibit highly advanced devices which doubtless prove of great value in the plant's economy. It is in its floral structures, however, that the complex specialisation of this weed of the country side culminates. The flowers of orchids show such marvellous adaptation 


\section{LIFE HISTORIES OF FAMILIAR PLANTS}

for insuring insect-fertilisation that the slightest acquaintance with their wondrous details is sufficient to reveal what is almost the equivalent of human design. Darwin, in referring to the flowers of one of the species belonging to this same genus, says: "As in no other plant, or indeed in hardly any animal, can adaptations of one part to another, and of the whole to other organisms widely remote in the scale of nature, be named more perfect than those presented by this orchis."

The science of homology has shown that the complex organisation of floral structure found in an orchid is but a modification of some more simple type of flower, such as a lily. A lily consists of five alternating whorls of floral organs, composed of three petal-like sepals, three petals, six stamens in two whorls of three each, and, in the centre, a pistil, or ovary, of three cells, or divisions; however, if the general reader should endeavour to trace these parts in an orchid flower his task would now be a difficult one, for instead of the flower being composed of fifteen parts, as in the lily, only seven now remain. Three sepals and two petals still exist as such; the stamens have disappeared entirely excepting the pollen-producing part of one of them. The lost stamens are combined with the pistil, or ovary, and with the remaining petal, to form the structures known as the column and the labellum respectively.

Such modifications of the original parts of a flower are, of course, not unusual; a familiar instance of such changes is that of the doubling of 


\section{THE WILD ORCHID}

a flower, where the numerous stamens of a poppy or an anemone become petals, and so produce the socalled "double" flower. But why has the orchid disposed of five out of six of its original stamens that produce the valuable fertilising pollen ? Surely a progressive plant such as the spotted orchis cannot afford to dispense with its reproductive parts! The fact is, the orchis conducts its floral diplomacy with such skilful adjustment that it can do, with its one partially-remaining stamen, as much as, or even more than its remote, lily-type ancestors were able to do with their six.

The spotted orchis caters more particularly for the visits of bees and several species of flies. How perfectly it caters I will now ask the reader to observe. Upon looking closely at Fig. 8I (Plate 57) it will be seen that the lower half of the flower is composed of a large petal (which originally was probably a petal and two stamens). This petal is, behind, drawn back so as to form a spurlike nectary and, in a general way, the whole is.called the lower lip, or labellum. On the surface of this lip, it will be noticed, appear some deep purple spots all of which converge into the hollow of the nectary. As it stands the lip is a landing-stage for the bee or fly, and to prevent any waste of time or misunderstanding on the part of the visiting insect the purple-coloured spots immediately conduct it to the nectary ; it therefore has no excuse for blundering by searching underneath the flower, or elsewhere. So at once on its arrival it plunges its head and proboscis into the nectary. Once again 


\section{LIFE HISTORIES OF FAMILIAR PLANTS}

observing Fig. 8I (Plate 57), within the two upper hood-like petals will be seen a dark-looking object with a round, pale-coloured base that projects a short distance into the mouth of the tube of the nectary. This object is the remaining stamen that produces the fertilising pollen, and around its pale-coloured base at the top of the tube are the stigmas to receive the pollen-but the pollen of another flower.

The visiting bee or fly, then, lands upon the stage or lip of the flower, and inserts its proboscis to search the nectary. In reaching to the depths of the tube, its head, eyes, or some part of its proboscis invariably comes into contact with the pale-coloured disk of the stamen that projects into the tube of the nectary. This disk is viscid, and immediately the insect touches it the disk adheres to the part in contact with it, and at the same time the little sac that encloses the pollen bursts open. The insect having quenched its thirst, withdraws its proboscis and flies away; but not as it came, for on its forehead, or on some part of its proboscis, it now has two tiny but beautifully-formed clubs which it withdrew, together with the viscid disk, from the stamen sac, or pouch. These two little clubs stand upright upon the head or some other part of the anatomy of the insect, when first withdrawn from their cover, but, as it flies, in about half a minute, they fall forward, towards the apex of its proboscis.

I have endeavoured to illustrate this proceeding artificially in Figs. 85 and 86 (Plate 60), since a I38 
PLATE 60
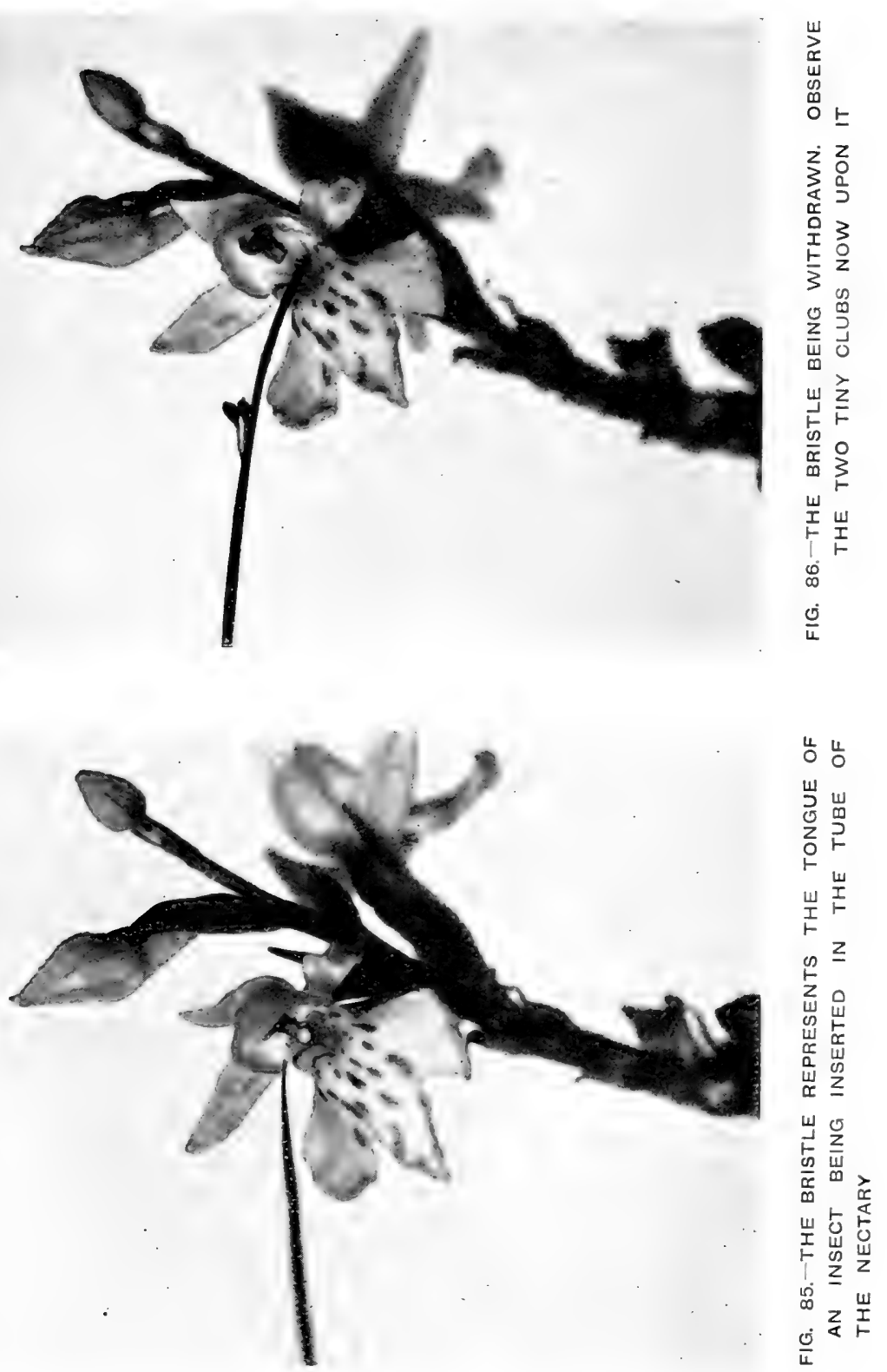
PLATE 61

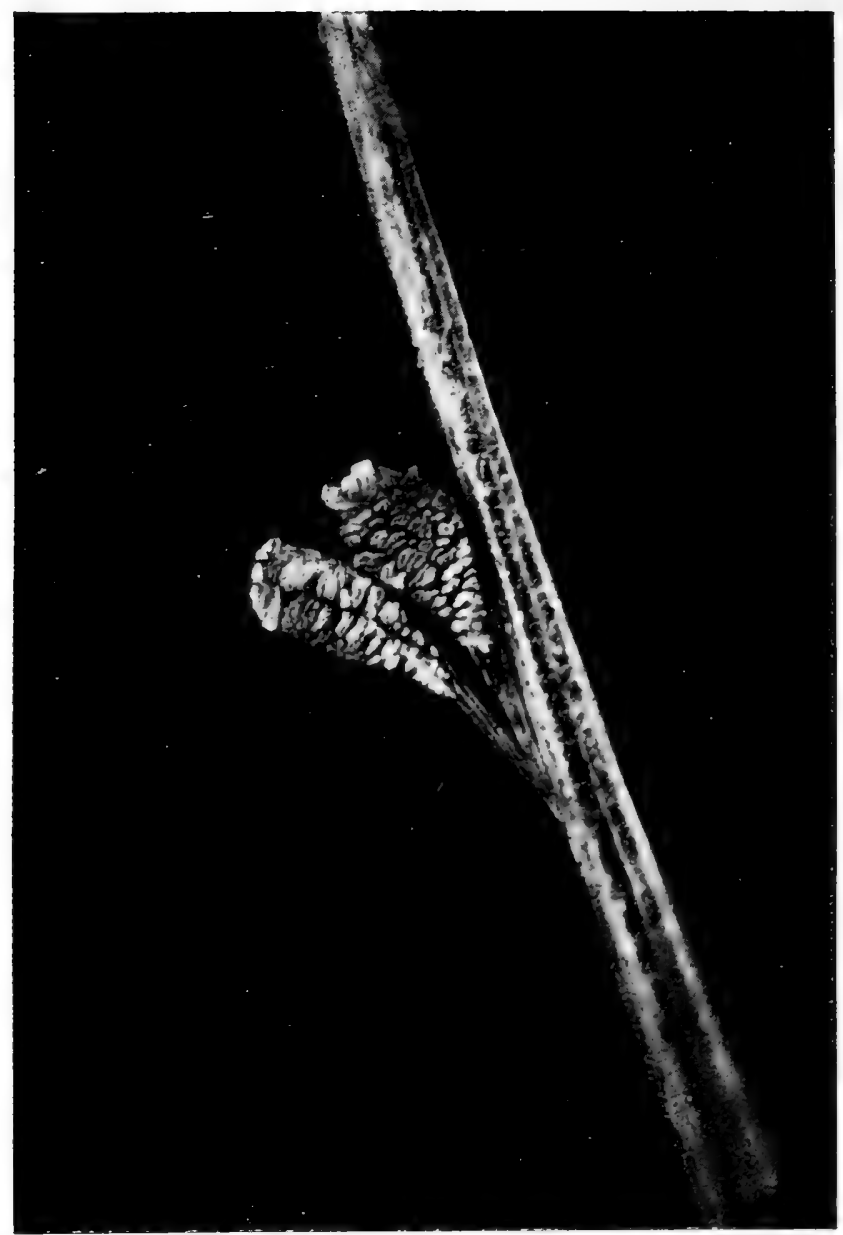

FIG. 87.-MAGNIFIED VIEW OF THE FOLLEN CLUB3 


\section{THE WILD ORCHID}

lively fly or bee scarcely lends itself to the camera for showing the details I am describing. In Fig. 85 appears an enlarged view of some of the flowers (their natural size is shown in Fig. 80, Plate 56) together with a delicate bristle supposed to represent the tongue or proboscis of the bee. In Fig. 86 (Plate 60) the bristle has been pushed into the tube of the nectary and then withdrawn. Observe the two minute clubs now attached to the bristle. Owing to the delay of arranging for photographing, the clubs have had sufficient time to fall from their vertical position and are now pointing towards the end of the bristle, just as they would on the proboscis of the insect.

I have previously remarked that the stigmas which receive the pollen were below the sticky disk of the stamen, so that if this bristle were directed into the same flower again, the ends of the clubs would now come into direct contact with the stigmatic surfaces, and the flower would then be self-fertilised, for each of the clubs is a mass of pollen grains held together in little groups by means of elastic or viscid threads. The insect, however, does not visit the same flower twice in succession, but flies to another, and as it travels the little pollen clubs adjust themselves from vertical to horizontal positions, so that the next flower visited will receive the pollen. Such is the ingenious device by means of which the spotted orchis effects the cross-fertilisation of its flowers. Provided that an insect visits the flower, it is scarcely possible for things to go wrong; the 


\section{LIFE HISTORIES OF FAMILIAR PLANTS}

results of its one stamen are so sure that it is of more value than the six of its remote ancestors.

In Fig. 87 (Plate 6I) is shown a further magnified view of the little pollen masses. Each tiny flake of which they are seen to be built is composed of numerous grains, corresponding to the pollen dust so familiar in lilies and other flowers, held together by sticky threads. When the clubs touch the stigma some of these flakes adhere to it, for the viscid secretion of the stigma possesses a greater pull than that of the threads of the pollen masses. A pair of clubs, therefore, may fertilise the stigmas of several flowers.

Surely, then, this wild orchis that revels in my roadside plot has attained a most complex development. Each modification of its original structure that has served its species in good stead throughout the ages of its evolution has been faithfully preserved until we find now this complex aggregate of their merits. The obvious adaptation of the floral structure, and the ingenious method adopted for the removal of the pollen masses and for their safe and sure conveyance to a neighbouring flower are striking features indeed, but it is the minute details, the insignificant nothings, as it were, of the scheme that are perhaps most striking.

For instance, several observers discovered that after all this complex arrangement of a landingstage, honey guides, and a spur for the nectary, no nectar or honey was secreted by flowers of this genus, a most contradictory state of affairs, for it 


\section{THE WILD ORCHID}

was scarcely reasonable to assume that insects would persistently visit flowers where they received no payment in return. Darwin examined the flowers after sunshine, after rain, and at all hours and under various conditions, but no nectar could he find ; yet he observed that flies continually visited the flowers and inserted their probosces for considerable periods of time. Later he discovered within the nectary tube a delicate lining membrane which could be penetrated very easily, and which when punctured yielded copious juices. Now this arrangement occupies the insect much longer than if it had simply to insert its proboscis and suck up the free nectar, and Darwin suggests that this delay serves to insure that the viscid pollen disk is securely attached before the insect leaves the flower.

So we might investigate a hundred other little points of striking interest, such as the changing of the position of the pollen masses; or the fact that the viscid base of the stamen remains sticky while in the flower, but dries immediately on its removal, attaching itself to the insect in such a manner that it cannot be removed until it has visited many flowers. It is impossible to shake the pollen masses from a bristle or similar foreign body after they are once attached; the insect therefore, has no alternative but to work them off in the course of its travels.

Finally, I may mention that the ovary or seed vessel of each flower is twisted. What is the necessity for that curious feature? It so happens 


\section{LIFE HISTORIES OF FAMILIAR PLANTS}

that the large petal used as a landing-stage was in the primary arrangement of the flower the upper petal; as, however, it could not in that position serve any useful purpose, by twisting round the seed pod and bringing it to the lower level it provided an excellent landing-stage for insects; thus it came to hold its present position.

There is much work yet to be done on my orchid plot, many features still remain that need investigation; but perhaps I have said enough to make the thoughtful reader reflect that plants are not quite the insentient organisms that we lordly members of the human race sometimes consider them to be. There is purpose in even the minutest detail of their complex structures; their intelligence may be unconscious, but it is none the less real on that account.

[NoTE.-With reference to the theory broached in pp. I3I to 135 , a correspondent from Ireland who has read this chapter writes: "It occurred to me that, as we have no reptiles of any sort here in Ireland, if the leaves bore no markings it would be additional evidence in proof of your theory. I found plenty of specimens of the plant and the leaves are unmarked, as you will see by enclosed." How far this will prove correct I am unable to foretell. Personally, I am inclined to think that spotted specimens will be found in Ireland; tubers or seeds could readily be conveyed there. The specimens sent were the correct species, and bore no spots or markings of any description.] 


\section{CHAPTER XII}

THE QUAKE.GRASS (Briza media)

IN the lane where my orchids grow, I find, flourishing close beside them, an abundance of the familiar quake-grass. It seems remarkable, at first, that these two entirely different plants should thus be existing side by side, since their structure and habits are so essentially unlike that we should not expect to find them in the same situation. Our wonder is increased when we learn that the quake-grass-like the wild orchis which I have described in the previous chapter-is also a modified member of the Lily family ; indeed, I may go farther and say that all species of grasses are degenerate lilies. As we have previously seen, the wild orchis has evolved its primitive lily structure until its once simple petals, stamens, and ovaries have become complex and marvellously adapted in their organisation for insect-fertilisation ; the grasses, however, have taken a contrary course and have lost nearly every trace of their primitive petals and those parts jwhich serve to make them attractive to insects, and have now become most perfect types of wind-fertilised plants.

In the hazel and other catkins, previously considered, we observed that the flowers had 


\section{LIFE HISTORIES OF FAMILIAR PLANTS}

become dwarfed, crowded, and insignificant, because when insects are not required to assist in pollinating the stigmas, the plant derives no advantages by producing large and conspicuous flowers. So long as the plant can so arrange its blossoms that the wind can readily remove the pollen from the stamens and distribute it amongst the stigmas of other plants of the same species, cross-fertilisation is effected, and the plant is enabled to produce strong and healthy seed, and thus attain its highest functions by maintaining the strength of its species.

Look carefully at Fig. 88 (Plate 62). Of course the inflorescence of the quake-grass is quite familiar; even those who have never seen it growing know it as a favourite decorative plant in vases in nearly every home. Nevertheless, few who observe its little, hanging spikelets of flowers (for each scaly spikelet consists of six or eight distinct flowers) ever think how perfectly adapted is this delicate and elegant floral arrangement for the functions it has to serve in the interest of its species. Therefore, let us for the moment, forget the æsthetic and ornamental aspect of the quakegrass and consider only the utility of its structure ; for, although we gather it on account of its delicate beauty, yet the latter has no function in the economy of the plant. The inflorescence it presents to us is one most perfectly adapted to wind-fertilisation, and the charm its delicate form possesses for us, is purely a coincidence.

We have but to consider attentively these 
PLATE 62

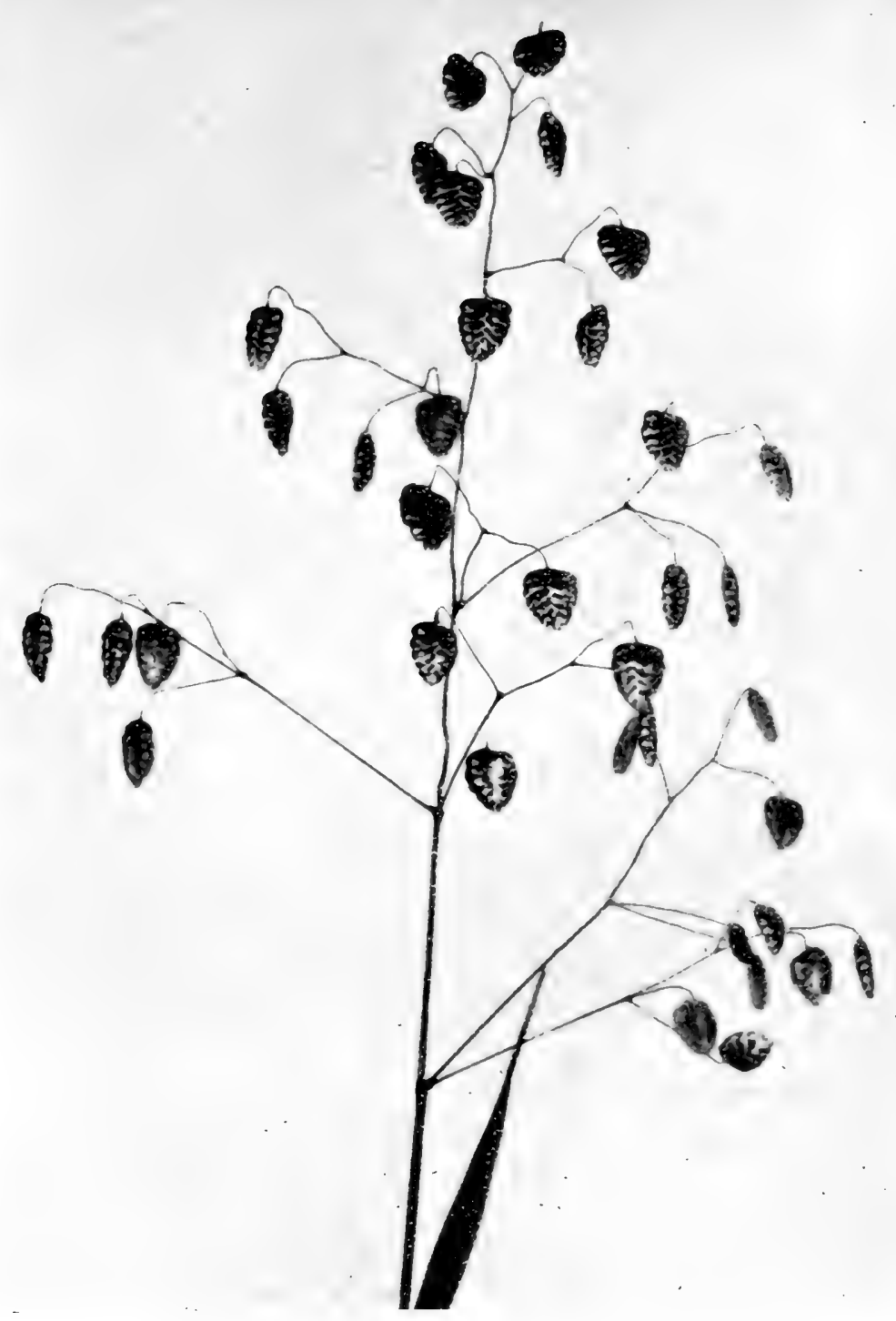

FIG. 88.-QUAKE-GRASS WITH UNOPENED SPIKELETS 
PLATE 63

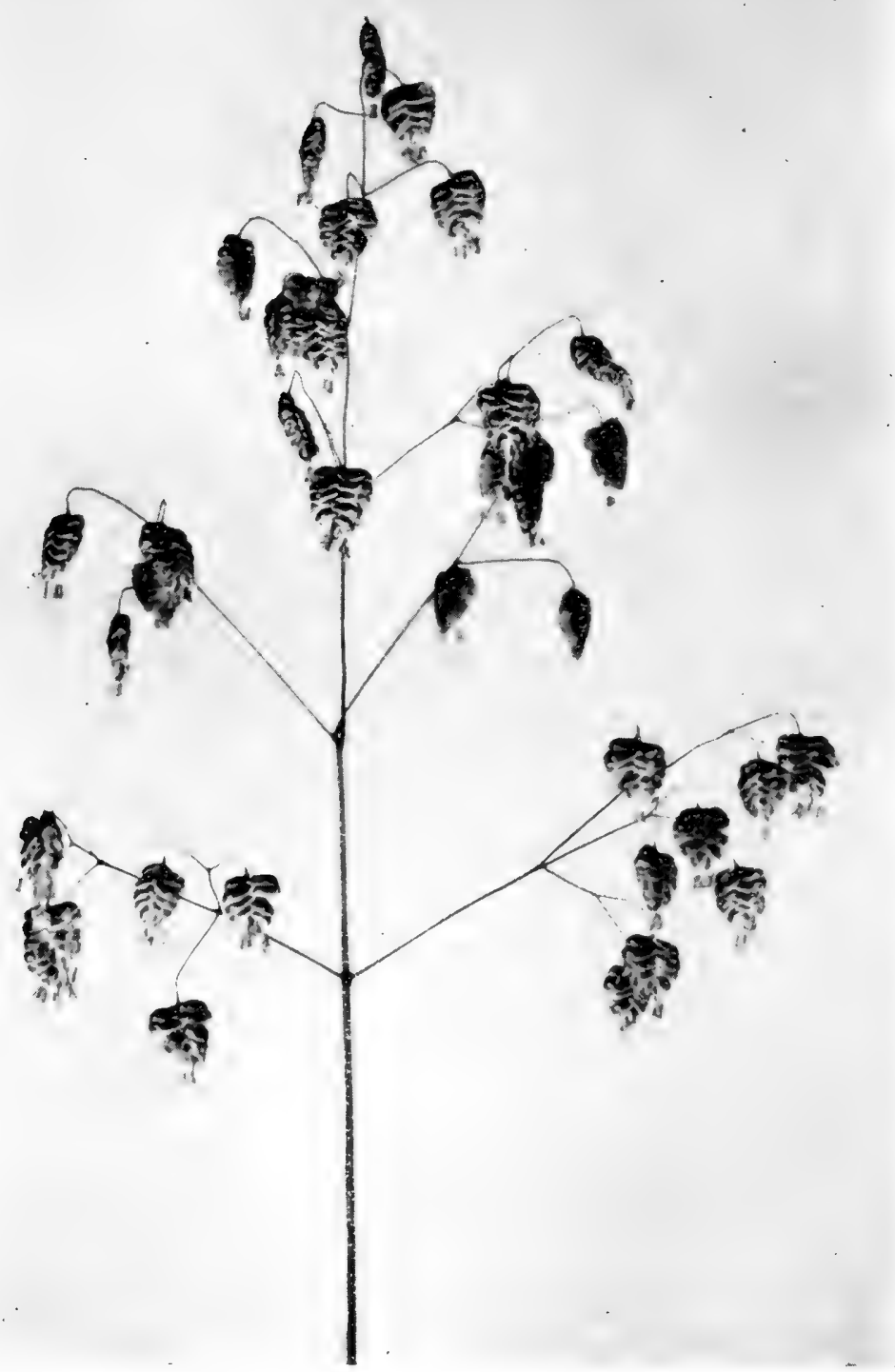

FIG. 89.-QUAKE-GRASS WITH OPENED SPIKELETS AND STAMENS PROTRUDING 
slender branches to realise that their delicacy is of the greatest utility. Each little spikelet is suspended, as it were, on a delicate wire, susceptible to the slightest vibration, as its popular name implies. The quake-grass largely inhabits warm regions-even in the northern parts of Scotland it becomes scarce-and its structure consequently must be adapted to vibrate under the gentlest of breezes. A specimen, such as that shown in Fig. 88 (Plate 62), serves excellently for drying and preserving for decorative purposes, but it does not reveal the functions of the inflorescence, simply because the spikelets have not yet opened. In Fig. 89 (Plate 63) another example is shown, and there the spikelets are seen opening their flowers.

As I have previously stated, each spikelet consists of about six or eight complete little flowers, all packed closely together; sometimes the lower scales are barren. From between these scales, or glumes as the botanist terms them, of the fertile flowers some feathery stigmas first protrude, and these receive the pollen blown from older plants whose stamens have arrived at maturity. Later, the three stamens of each flower appear, their relatively large anthers, or pollen sacs, being suspended outside the scales on long delicate filaments, as seen in Fig. 89 (Plate 63), and more in detail in Fig. 90 (Plate 64). When they are fully extended, the anthers burst and shed their innumerable, tiny pollen grains, every delicate breeze moving the anthers on their $\mathrm{K}$ 


\section{LIFE HISTORIES OF FAMILIAR PLANTS}

fine filaments and shaking out into the atmosphere some of their pollen, while every stronger breeze vibrates the slender branches more vigorously and shakes out the anthers and pollen more effectively.

A single glance at the structure and details of the inflorescence will show how perfect is the whole arrangement. In oats and other grasses we find similar loose panicles of spikelets, likewise adapted for wind-fertilisation, but it seems to me that the familiar quake-grass comes first in the adaptation of its structure for wind-pollination. Its minute, well-protected flowers are so obviously suspended in space, on branches so delicate that even when growing closely they can scarcely intercept the course of the pollen through the air, while on the other hand the structure offers every facility for pollen dispersal through its extreme susceptibility to vibration.

Having observed the meaning and purpose of the inflorescence, we may now ask what proof there is for saying that these suspended spikelets are in reality degenerate lilies?

I have previously mentioned that the typical lily consists of three sepals (frequently coloured like the petals); three petals; six stamens in two whorls of three each; and a pistil or ovary of three cells. Now in the grasses the flowers have become so crowded together that many of the separate parts of these whorls have either united or entirely disappeared. Thus the calyx is usually represented by two dry scales, termed pales, and

$$
146
$$






\section{THE QUAKE-GRASS}

the petals generally consist of two other minute and almost obsolete scales, called lodicules; for petals are no longer needed. The stamens are usually three in number, one whorl being completely aborted; in some species the two whorls still remain, and in others one stamen from the remaining whorl disappears, leaving only two. The ovary is one-celled but bears two feathery stigmas. In Fig. 90 (Plate 64) appears a dissected flower from one of the spikelets of the quake-grass, and the pair of feathery stigmas and the three stamens together in one of the pales are there distinctly shown.

The flowers of grasses, therefore, now show very little of their original trinary arrangement, only the stamens keeping up a full three; nevertheless, there are many reasons for assuming that at one time they had all their whorls arranged in threes similar to those of the lilies of to-day. One of the two pales of the quake-grass even now bears two distinct midribs, showing that it was originally two; thus the calyx must have consisted of three sepals. Even the lodicules (the rudiments of the primitive petals), although often so minute as to be detected only by careful observation with the aid of the microscope-when represented at all in British grasses, - are only two in number, the third having been entirely crushed out in the smaller flowers, yet in the larger flowers of the bamboos (which are tall, exotic grasses) the three petals still remain entire. Thus we have direct evidence of these parts still existing in a large group of grasses. 


\section{LIFE HISTORIES OF FAMILIAR PLANTS}

The stamens remain three, probably because they hang outside the flowers, and having plenty of space for development there is little or no occasion for suppression. The ovary is only onecelled, but above it are two feathery stigmas, these indicating that once there were two cells; and just as one cell has entirely disappeared leaving only its stigma to record its former existence, so we may assume that the third one, together with its stigma, has been crushed out of existence still earlier in the history of the plant.

To deal with so large and controvertible a subject as the grasses in a brief chapter presents many difficulties. I trust, however, that I have written enough here to serve my present purpose in showing that this great group of plants, which numbers between three and four thousand species, over one hundred of which are British, consists, like the orchids, of highly evolved types of some lily-like ancestor. I say "highly evolved types" advisedly because, although the grasses have become degraded from their original form, yet they have made considerable progress as a family in other directions; indeed, they have carried adaptations for wind-fertilisation to their highest perfection, and consequently, they have become possessors of vast tracts of land all over the world. Their slender waving structures and hardy constitution, together with their perfect methods of windfertilisation, allow them to pioneer new districts largely irrespective of climate, and, of course entirely without dependence upon insect allies. 


\section{THE QUAKE-GRASS}

The grasses, therefore, as a family have been eminently successful in taking possession of the earth, but it is through their degeneracy that their success had been achieved; on the other hand the Orchid family has slowly evolved and developed to a greater complexity those characteristics it inherited from its remote lily-like ancestors.

Thus the two groups of plants have each reached the topmost points on entirely different branches of the organic tree. So different have they become that it is only by investigating the details of their structure, and guided by modern theories of evolution, that we are now able to understand how the Lily group has given origin to our choicest orchids and humble grasses, the latter, be it remembered, including man's most important cereal food-plants, such as rice, millet, wheat, barley, etc. 


\section{CHAPTER XIII}

THE WHITE OR DUTCH CLOVER (Trifolium repens)

At first glance one would scarcely think that the familiar red and white clovers are descendants, still further evolved, from that great family of Peaflowers to which, as previously seen, belong the laburnum, broom and gorse. It seems quite paradoxical to have to add, moreover, that these herbs of the meadows and pastures stand at the head of their family group, representing the most advanced and most highly specialised species. There are more than twenty recognised British clovers, and some of the simpler species still retain their primitive yellow flowers. It is, however, the better and more advanced kinds, those with white, pink, and purple flower heads, that most appeal to the non-botanist. But even they scarcely explain to those unacquainted with botanical science why the clovers should hold such high rank in their family group. Let us, thereore, give this point immediate consideration.

In the first place we have to recognise that the coloured heads of clover blooms are not single flowers like those of broom or gorse. In the case of the laburnum, previously referred to, it will be remembered that it produced its flowers in showy, pendent racemes. Also, I then pointed out that 
PLATE 65

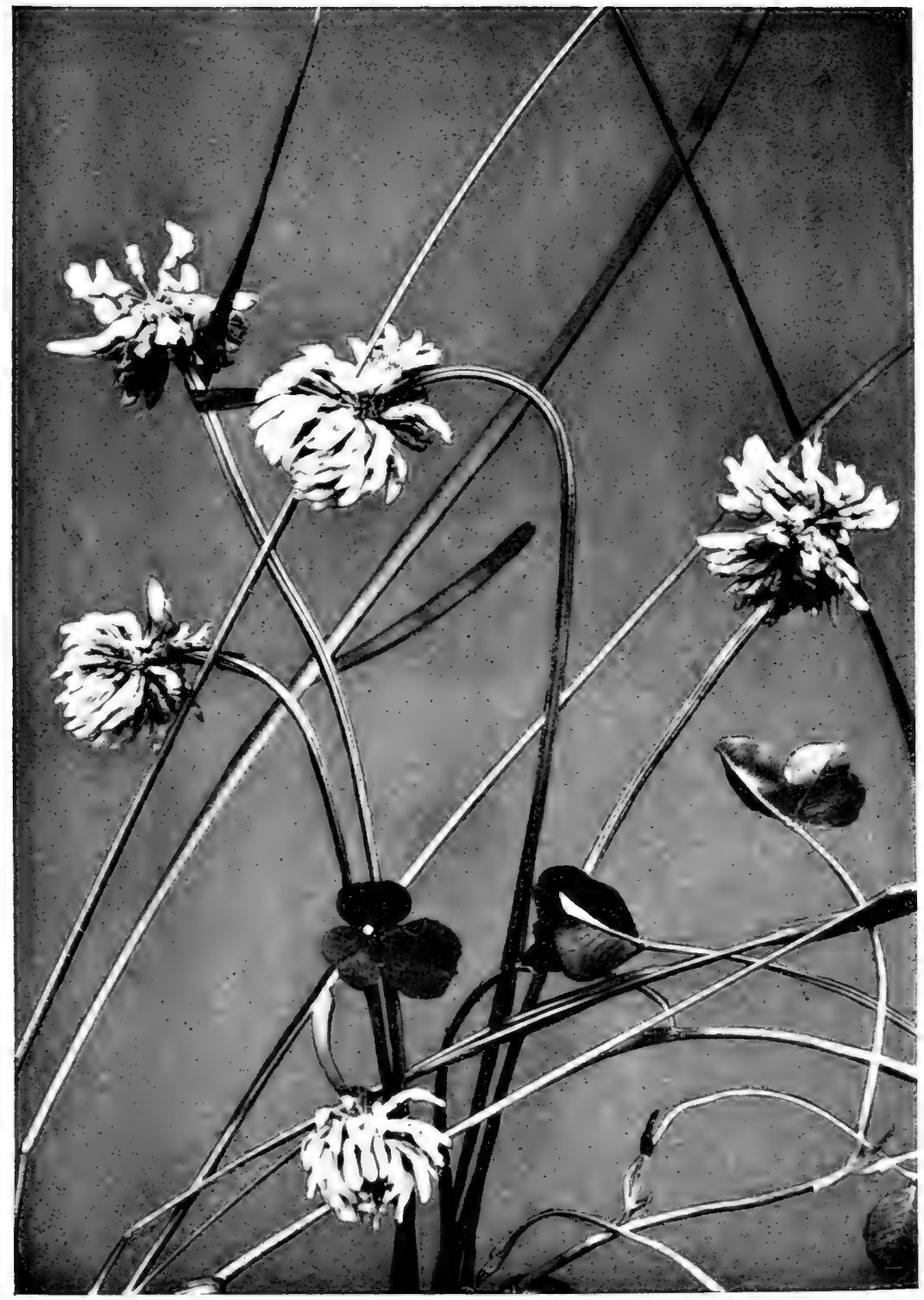

FIG. 91.-WHITE OR DUTCH CLOVER 


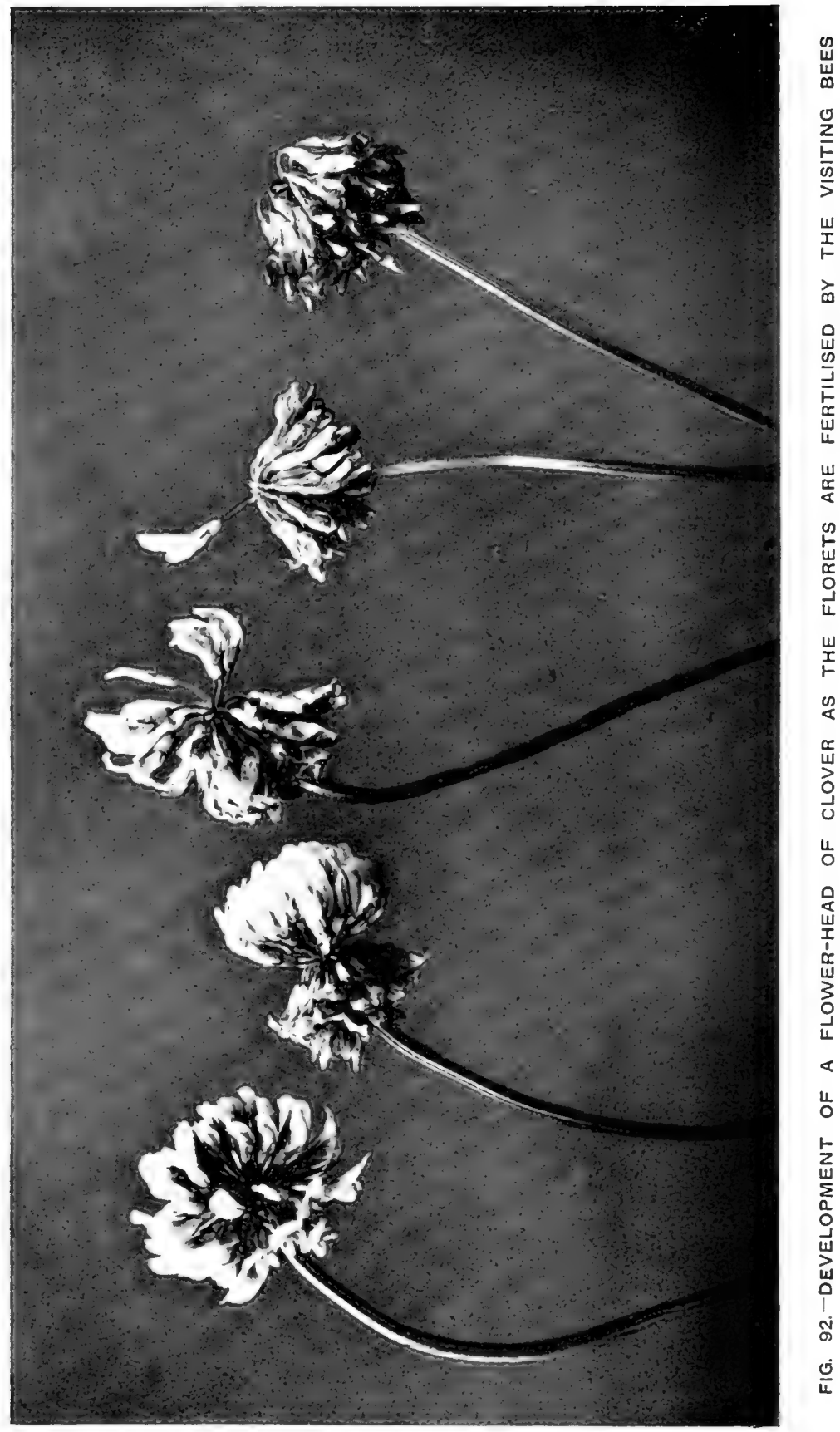




\section{THE CLOVER FAMILY}

the laburnum had probably seen comparatively few vicissitudes in the course of its evolution, and consequently, it most likely retains best the main characteristics of the ancestral type.

Now, the raceme of yellow flowers was, I think, the kind of inflorescence possessed by the progenitor of the Pea-flower family. My reason for thinking this is because all the other forms of floral arrangement in the family could be readily produced from a raceme such as that of the laburnum by simple modifications. In the vetches (which probably best represent the leaves of the family ancestor) and wild peas we have presented every gradation from the clustered raceme with numerous flowers to those of two or three flowers only, and finally to solitary blooms in the axils of the leaves, such as those of the broom and gorse.

Now it only needs a glance at Fig. 9I (Plate 65) to see that the heads of Dutch clover there shown consist of numerous small flowers-pea-flowerswith the youngest in the centre and the older flowers forming the outer whorls of the group. Similar methods of grouping often occur when the individual blossoms are small. It will be remembered that the wild camomile, the coltsfoot, and the Composite family generally, arrange their minute flowers into compact heads. By thus grouping themselves, such tiny flowers can make a larger show and so succeed better in attracting the attention of passing insects.

Indeed, it is quite a common device amongst 


\section{LIFE HISTORIES OF FAMILIAR PLANTS}

plants of entirely different families, all of which seem to have hit upon similar means of clustering their minute flowers and thus, by their numbers, competing with their neighbours bearing larger blossoms. How well this purpose is effected is readily appreciated by glancing at the flowers of meadow-sweet, elder, lilac, and the large compound umbels of the wild angelica (Fig. I I2, Plate $8 \mathrm{r}$ ), and other members of its family.

So it occurs that in the Pea-flower family, the clovers, which bear the smallest flowers, have them grouped into compact heads; in the bird's-foot trefoil and the kidney vetch they are arranged in looser heads; and in the true vetches and wild peas, where the flowers are a little larger, we find them, more or less, in closely arranged racemes, a form of inflorescence that is well developed in the laburnum. Finally, we have the larger flowers of the family, as the broom and some of the peas, produced singly. Of course, no hard and fast line can be drawn regarding this floral arrangement, because exceptions occur in all branches of the family ; it may, however, be applied in a general way, for the exceptions can usually be accounted for when their habits and environment are taken into consideration.

Now this grouping of the minute flowers into showy heads tends to show that the clovers have been considerably specialised and evolved. It may be asked, however, why not view the matter from the other side and say that the raceme of flowers was evolved from the clover's compact 


\section{THE CLOVER FAMILY}

head of florets, that it was slowly lengthened out and the flowers gradually made larger? The suggestion is reasonable enough, but it so happens that the clovers possess other features, besides that of their closely arranged heads of florets, which tend to show that they are more evolved and of a higher type than the other genera of their family.

By pulling to pieces one of the larger peaflowers, such as broom or sweet pea, we shall find that it possesses five coloured petals. A glance at Fig. 65 (Plate 44) will show these. There is first a large petal above, known as the "standard," and below this is another pair termed the alæ or "wings," and inside these still another pair (often more or less united) designated the carina or "keel." These same parts may also be readily traced in one of the little blossoms of the clover ir a magnifying lens is used when examining it. There is, however, one important difference. The clovers have joined together their petals at the base to form a tube, at the bottom of which the nectar is stored.

Now I have previously pointed out (p. Io) when dealing with the inflorescence of the wild camomile and foxglove, that this joining together of petals is a sure sign of advancement, because the flower is then adapting its structure to the requirements of some particular insect visitors. Seeing that this feature is, in the Pea-flower family, conspicuously developed only amongst the clovers, there is good reason to suppose that they are more highly evolved than genera with separate petals. 


\section{LIFE HISTORIES OF FAMILIAR PLANTS}

Furthermore, there is the consideration of colour in the flower-heads of the clovers. The progenitor of the Pea-flower family doubtless had yellow blossoms, and this colour, as Grant Allen demonstrated so ably, is the lowest and most primitive colour of flowers; white, pink, red, purple, and blue representing the order in which floral colouration was evolved. Now, amongst British pea-flowers yellow and orange reds are the predominating hues. Here and there in the various genera a species has progressed sufficiently to produce pink or blue-tinted flowers, but it is in the clovers that we find a complete evolution from the family yellow through white, pink, red, and purple stages. The latter colour is a favourite with the bees, insects for which the clovers particularly lay themselves out when uniting their petals into a narrow tube.

It is now, I think, fairly clear that the clovers have, like the wild camomile, by continual adaptation acquired blossoms specialised both in form and arrangement to meet the convenience and requirements of their particular insect guests. The little flowers begin to mature with the outermost whorl, the inner whorls then succeeding just as in the daisy type of inflorescence; and the bee quickly works around amongst the ripe flowers, sucking up their sweet nectar and at the same time conveying to the stigmas the pollen it has brought from the flowers of other heads it has previously visited. Naturally, the bee fully appreciates this arrangement of flowers which permits 


\section{THE CLOVER FAMILY}

it to get a large supply of honey in a short time with very little work. Even in the convenient racemes of blossoms the bee must move from one flower to another, but in these closely-arranged heads, it may thrust its proboscis into flower after flower with the slightest change of position; while, conversely, this keen appreciation of the bee results in the clover getting nearly all its stigmas pollinated, and so, by the law of heredity, the plants are enabled further to evolve in their offspring their specialised features.

The familiar white or Dutch clover may be found in almost any field or piece of waste ground or even at the edges of the dusty roadside, and it is curious to observe how the plant assists (unconsciously) its insect guests. I have endeavoured to show this in Fig. 92 (Plate 66), where first a newlyopened head of bloom is seen. In the second example a head is shown that has been visited by the bee, and all the flowers that were then mature and received its attentions have, it will be observed, turned down out of the way towards the stem. Later, most of the remaining flowers receive a visit, and in the third example all excepting some two or three are seen bending their little stalks towards the stem. Even the youngest central flowers are not neglected as they ripen, and the fourth example shows one unfertilised blossom left alone endeavouring to attract, with its tiny petals, the eye of some busy bee; eventually its turn comes, and it also turns downwards to join the other members of the head, as in the last example. 


\section{LIFE HISTORIES OF FAMILIAR PLANTS}

No bees are seen to visit a flower-head such as that shown in the final example; indeed, as soon as the stalk of each little flower bends down the petals begin to lose their colour and become brown and shrivelled; nevertheless, they do not fall away, as petals often do, for they have yet another function to fulfil. Within the centre of each little flower is a minute pod in which will ripen from one to four tiny seeds.

For, although but few people notice them, yet the clovers produce their seeds in pods, just as do peas, laburnum, broom and gorse ; indeed a peaflower postulates a seed pod more or less like that of the cultivated pea, or the broom. However, the clovers' little pods are so well hidden, wrapped in their brown and shrivelled petals, that the flowerheads appear dead while they are maturing their seeds; hence we fail to observe the tiny pods. Furthermore, as the seeds ripen, the pods burst open and, being down-turned, the tiny seeds drop from them and fall amongst the grasses, where they germinate. If, when the young white clover plants develop, they find themselves too crowded, that difficulty is overcome by their creeping stems which work their way amongst the herbage, rooting here and there at intervals as they travel.

Such, then, is the manner in which the familiar white or Dutch clover conducts its life economy, and how successful its working principles have proved is readily testified by the fact that it appears on almost all land where grasses will grow; and, as we have seen in the previous 


\section{THE CLOVER FAMILY}

chapter, the grasses are a particularly successful group of plants, although their success is brought about by entirely different means from that employed by the clovers.

What I have written above applies only to the familiar white or Dutch clover, for the red and purple species do not turn down their flowers as they are fertilised; indeed, it may be said that each of the twenty or more British species of clovers has its own particular devices in the struggle for existence. The red and purple clovers, therefore, conduct their affairs on quite different principles from the white species.

There are a few other white and also pink and yellow species which turn down their flowers after fertilisation, just as the Dutch clover does, but even these species differ amongst themselves very considerably in the manner in which they protect their pods while their seeds mature. Sometimes the pod is covered by the calyx, or green outer parts of the flower, which enlarges and develops about it irritating hairs or sharp prickles, thus making the pods unpalatable to sheep, donkeys, and other grazing animals; in other cases they are considerably hardened for the same purpose; and, finally, there is the Subterranean Clover (Trifolium subterraneum) that only bears some two or three flowers in each head, and consequently has to take great care of its pods. Its method is not to turn down its individual flowers, as the white clover does, but, instead, immediately after fertilisation, the whole head is turned earthwards; and, 


\section{LIFE HISTORIES OF FAMILIAR PLANTS}

marvellous though it may seem, the plant then buries its pods in the ground, and so sets its own seeds.

It happens that, although the subterranean clover has now only two or three perfect flowers in each head, yet by descent it should have many. more, and when the pods begin to ripen, traces of its undeveloped flowers then appear from the centre of the head in the form of several curious, short, five-spined fibres.

All the five spreading spines on these blunt fibres are the modified remnants of the five lobes of the calyx of one of the abortive flowers of the head; these now are developing for an entirely different purpose. As the head bends down and comes in contact with the soil, the ripe seed pods bend back close to the head, and thus the spiny fibres lead the way; slowly they work their way nto the ground like an auger, and in this manner the seed pods are sown, and at the same time protected while the sowing process is taking place. By this modification of its flower-head the subterranean clover can afford to dispense with all its flowers but two or three in each head, and can even then better hold its own on the dry and closely-grazed pastures where it is generally found. Its adopted methods of sowing its seeds insure so well the development of the offspring that the abortive flowers are more valuable to the species in their modified form than if they fulfilled their ordinary functions in the flower-head.

Indeed, this straggling little clover probably $15^{8}$ 


\section{THE CLOVER FAMILY}

represents the most specialised and most highly evolved of all British pea-flower plants. Its heads of only two or three flowers might, without reflection, be looked upon as a sign of degeneration, but a reduction in the number of fruits or seedproducing parts, is often a sign of advancement. Plum and cherry trees, for example, produce only one seed as the product of each flower and fruit, but other members of their family, as the raspberry, blackberry, strawberry, etc., develop numerous seeds in each "fruit." The plum and cherry type of fruit is particularly attractive to man and the larger animals, and this insures a greater chance that the hard seed of the fruit will be distributed than is the case with the numerous smaller seeds that largely depend upon birds for their distribution. Thus one large fruit with a pretty sure prospect of dispersal is of more value than a number of smaller ones, many of which may be overlooked by the natural distributing agents.

So it is with the subterranean clover. It has discovered that, with two or three pods of seeds, and a well-organised scheme for their protection and sowing, it is able to hold its own much better than if it produced a bold head of little pods full of rich seeds that would make a tempting mouthful to the first hungry sheep or goat that happened to see it. 


\section{CHAPTER XIV}

\section{THE STONECROPS (Sedrm?)}

THERE is a piece of the flower border in my garden that faces full south, and the soil in this area is dry and stony. In the summer-time nearly every plant that grows there gets scorched by the heat of the sun and for lack of moisture. There are two species of plants there, however, that thrive and flourish amazingly; and, although they are very unlike in appearance, yet a botanical eye will readily detect that they come of the same genus.

These plants are known familiarly as Stonecrops. The first is the common Orpine, or Livelong (Sedum Telephium), a fleshy-leaved plant (Fig. 93, Plate 67), about twelve or sixteen inches high, whose corymbs of pink or purple flowers begin to appear about the middle of August. Its nectar is dearly loved by numerous insects, as bees, drone-flies, hover-flies, and especially by the peacock, red admiral, and tortoiseshell butterflies.

The other plant is the familiar Wall-pepper (Sedum acre), a low-growing plant that spreads itself over the ground in stony and sandy places like a green carpet, its golden yellow flowers appearing about the middle of June. The wallpepper derives its popular name from the fact that I60 
PLATE 67

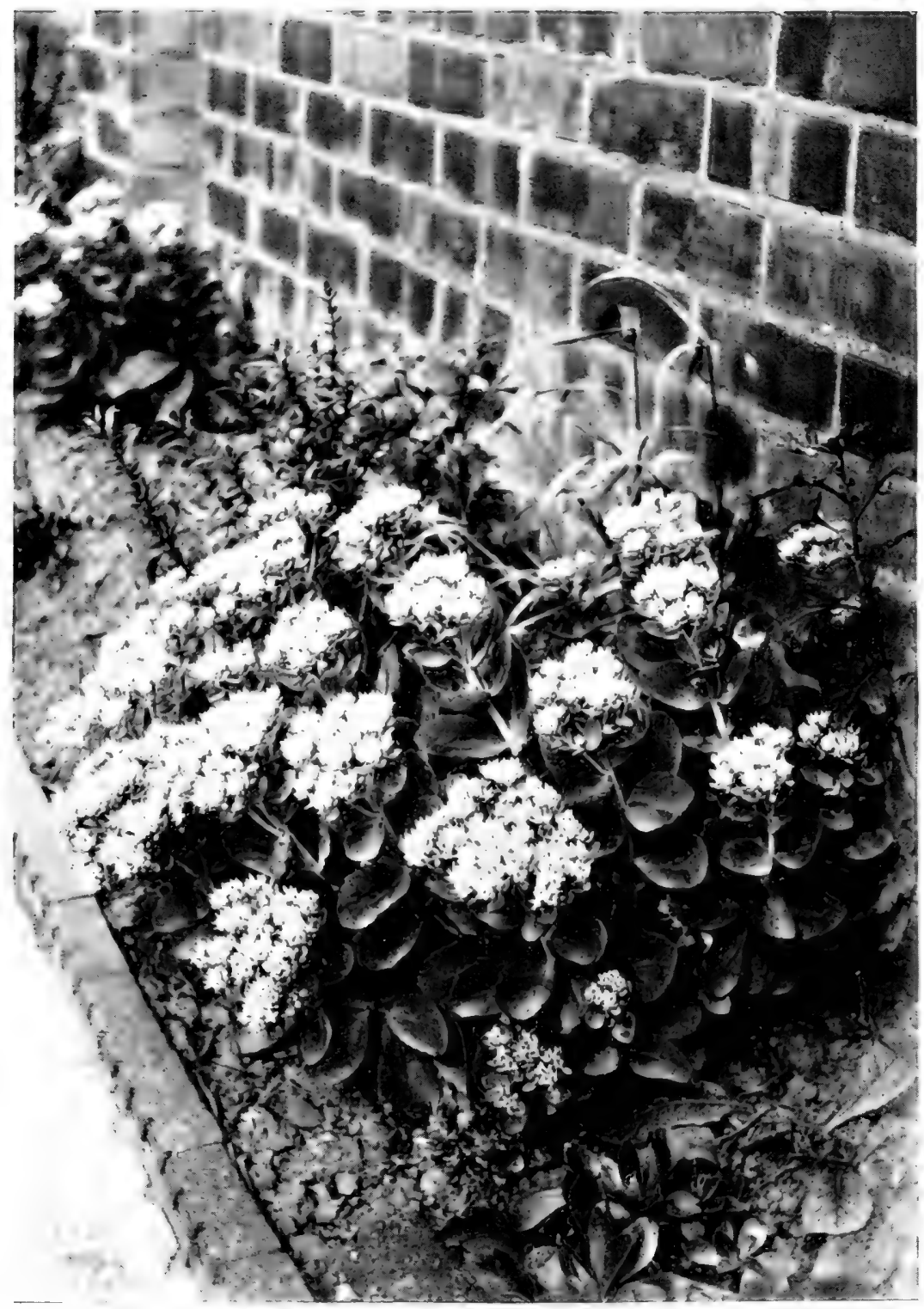

FIG. 93.-THE ORPINE, OR LIVELONG 



\section{THE STONECROPS}

its favourite habitat is the tops of walls and similar places, and from the additional fact that its small thickened leaves and stems are biting to the taste. In Figs. 94 and 95 (Plate 68) the plant is shown in detail, and also growing in the mass on the roof of a barn ; but to appreciate it properly in the latter case, its expanse of bright green, surfaced with its golden star-like flowers, should be seen in the bright sunlight.

There are some nine or ten species of these stonecrops found in Britain, and the wall-pepper represents the smallest of them, while the orpine is the largest; between the two plants we get species showing almost every gradation from the little thickened and closely-imbricated leaves of the wall-pepper, to the large, fleshy ones (often more than two inches across) of the orpine. All the nine or ten species, however, are succulent; and it is this latter feature to which I particularly wish to call attention now.

These plants have, like the cacti considered in an earlier chapter, adapted their structures to dry rocks and stony situations. They absorb moisture and store it in their tissues against a time of drought. I have endeavoured to illustrate this characteristic in a practical way in Figs. 96 to 99 (Plates 69 and 70). The first figure shows a branch of the orpine placed beside another of a thin-leaved plant, the Mock Orange (Philadelphus vulgaris). As will be seen, both branches are arranged on the end of a perforated box, and exposed to ordinary daylight, and without a 


\section{LIFE HISTORIES OF FAMILIAR PLANTS}

supply of water. Fig. 97 shows them half an hour later; the mock orange is seen to have almost half collapsed, owing to the evaporation of water from its tissues. Fig. 98 depicts them again six hours later. The orpine looks very much the same as it did in Fig. 96 ; but the mock orange presents a very different appearance. Finally, Fig. 99 shows the branches twenty-six hours later. The orpine is there seen just beginning to show signs of exhaustion. However, it only needs a little moisture quickly to regain its former appearance : but as much could not be said of the mock orange.

It is obvious, from the experiment thus illustrated, how well equipped are these succulent plants for growing in the dry and stony places they inhabit; hence, too, their popular name "stonecrops." These plants are the "cacti," as it were, amongst British plants, our native "vegetable camels"; although they bear no relationship to the true cacti, which are entirely exotic. How very differently, though, do they conduct their economy when compared with the desert-loving cacti. Here we find little or nothing in the way of protective devices, such as irritating hairs and sharp spines.

Why are not these succulent plants likewise protected? The answer is, that in the clefts of the high rocks and on walls, where the stonecrops grow, the plants have had few or no dangerous enemies to contend with in their habitat. Also, as they chiefly throw up their branches in the I62 


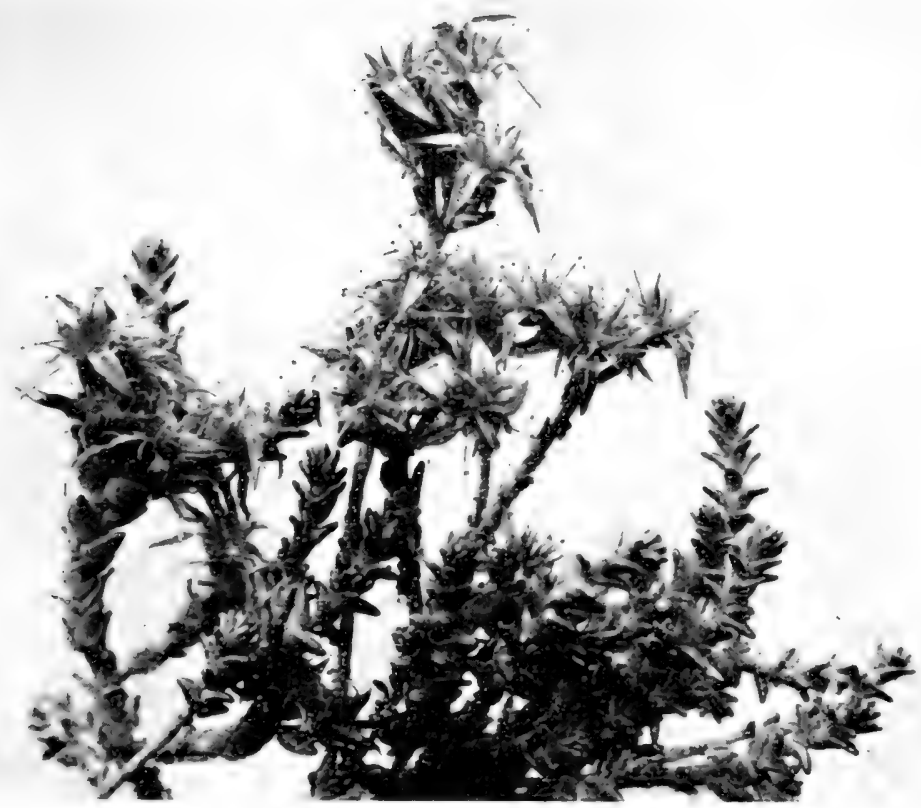

FIG. 94.-WALL-PEPPER (natural sizi)

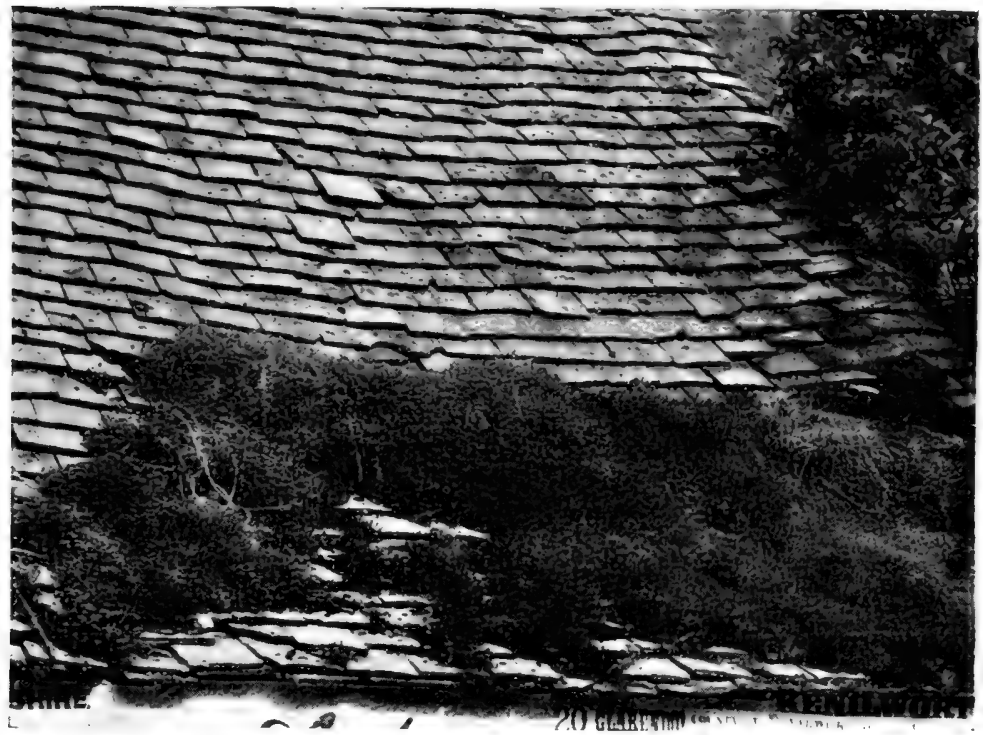

FIG. 95.-WALL-PEPPER GROWING ON A ROOF 


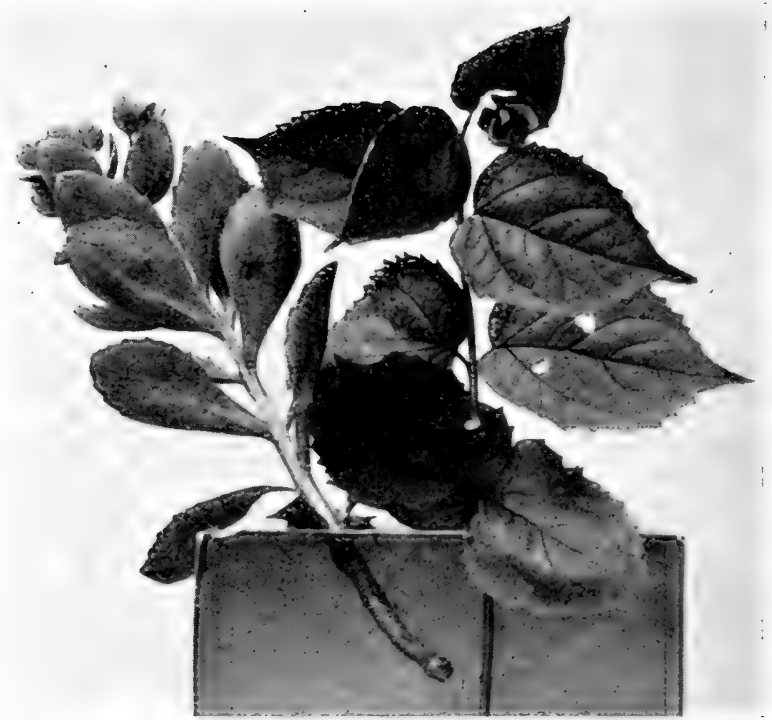

FIG. 96.- BRANCHES OF ORPINE AND MOCK ORANGE EXPOSED TO DAYLIGHT AND WITHOUT WATER

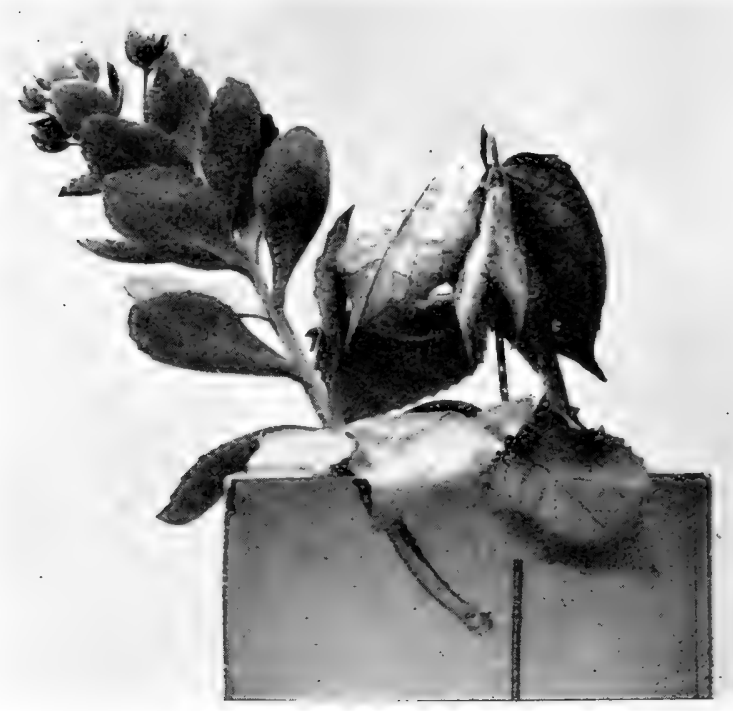

FIG. 97.- HALF AN HOUR LATER THE MOCK ORANGE HAS HALF-COLLAPSED 


\section{THE STONECROPS}

summer season, when vegetable food is abundant, vegetable-feeding animals would scarcely trouble to climb difficult rocks and heights in search of them.

Hence, the stonecrops have had a very uneventful career, going their way more or less unmolested; even the ground they occupy is easily held, for few British plants can tolerate a stony soil and a scorching sun.

Consequently, we find that the structure of these plants is very simple. The leaves, in the larger species, are more or less round, like large fleshy scales. Competition for sunlight has not necessitated that they should assume lobed or deeply divided forms, like the plants of the meadows, hedgerows, and woodlands, where the struggle for light and air is ever keen and constant. Hence they have retained, more or less, their primitive shapes. In the smaller species, as in the wall-pepper, the little leaves have become closely arranged against their stems, for in this manner their smaller amount of retained moisture is better protected from the heat of the sun's rays and its evaporation retarded.

Turning to the flowers we find still greater evidence of the primitive simplicity of these plants. At some remote period in plant evolution, a great division into two distinct groups seems to have taken place (although why and how this division came about is one of the unsolved problems of science). One group proceeded to develop the whorls of its flowers in fives; i.e., five or ten 


\section{LIFE HISTORIES OF FAMILIAR PLANTS}

carpels, five, ten, fifteen or more stamens, five petals, and a calyx of five sepals. The other group arranged the parts of its flowers in threes; i.e., three or six carpels, three or six stamens, three petals, and three sepals. Concomitantly, other distinctive features were associated with each of these floral arrangements. The quinary division produced net-veined leaves and had two seedleaves in each seed; while the leaves of the trinary form were parallel-veined, and its seeds contained only one seed-leaf. Botanists distinguish these two groups as monocotyledons and dicotyledons-two ugly names which are used to indicate whether one or two seed-leaves (cotyledons) are contained in the seeds respectively.

From these two great groups of plants have descended all the flowering plants with which we are familiar to-day. Few are the species, however, whose flowers now retain their original numbers of fives or threes in each of their whorls. In the lilies, as we have previously noted, whorls of three are fairly well maintained, although their three carpels have combined to form one central pistil or ovary of three divisions; but in the orchids and grasses we find striking instances of divergence from the original trinary arrangement.

In the fivefold group of dicotyledons, the original symmetry is generally much more difficult to follow, although buttercups, dog-roses, daisies, etc., all show traces of their quinary arrangement. I64 


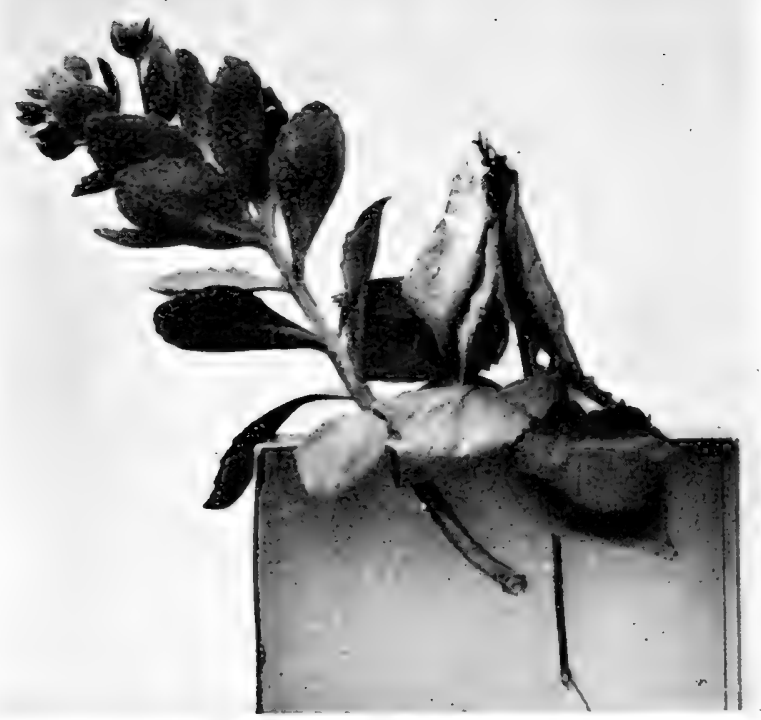

FIG. 98.- SIX HOURS LATER. THE ORPINE IS STILL FRESH

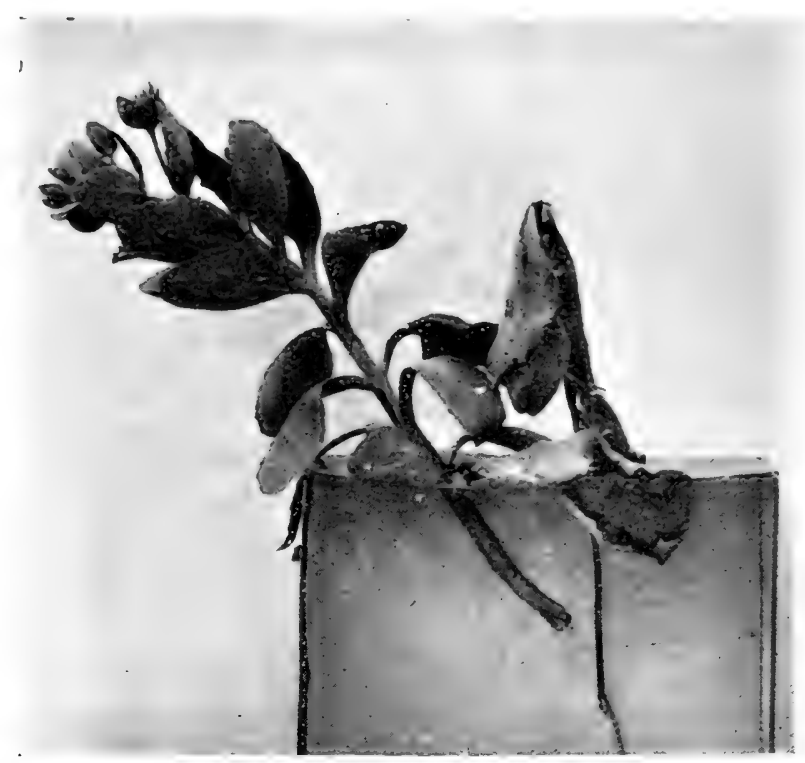

FIG. 99.-THE ORPINE BEGINNING TO FLAG TWENTY-SIX HOURS LATER 



\section{THE STONECROPS}

It is in the flowers of the orpine and the wallpepper and their allies, however, that we find preserved better than in any other dicotyledonous plants, the original arrangements of five. Their calyx usually consists of five sepals; their corolla of five petals ; their stamens of two whorls of five each, and their pistil of five distinct carpels or ovaries.

Thus the flowers of the stonecrops, like their leaves, have largely retained their primitive form, and for the same reason; namely, lack of competition. Their comparatively simple life has not necessitated complexity of structure in their floral organs such as that adopted by some of their neighbouring plants which have been continually harassed by competitors in their struggle for existence. At least, that is my reading of the structural details of these rock-loving plants. 


\section{CHAPTER XV}

THE DAFFODIL (Narcissus Pseudo-narcissus)

The wild Daffodil, or Daffy-down-dilly, is a most interesting flower. Only a glance at it is needed to see that it belongs to the monocotyledons, or to that group of plants which bear threefold flowers. Also, there is the further evidence of its grass-like, parallel-veined leaves (Fig. I00, Plate 7I); and if its little seeds are examined they will be found to have only one seed-leaf or cotyledon. Or, to put it more simply, the seeds will not split into halves as peas and beans will, for peas and beans are dicotyledons, and each half of their seeds represents one seedleaf, or cotyledon.

It may be said that botanists alone properly distinguish daffodils from lilies, because structurally considered the flowers are very similar. Both daffodils and lilies possess three petal-like, or coloured sepals; three petals; six stamens; and an ovary of three divisions. The daffodil has, however, in addition, a large tube or crown in its centre, but the botanist does not take this into consideration when distinguishing these plants from lilies; for in the narcissus and the jonquil this crown becomes very insignificant, and in the snowdrop, and also in the snowflake, it entirely 166 


\section{THE DAFFODIL}

disappears; and all these plants are daffodils, i.e., they belong to the Daffodil family.

The botanist's concern is merely whether these plants have a superior or an inferior ovary; a matter of interest to botanists only, for it simply relates to the situation of the ovary with regard to the perianth, or petals and sepals. If these floral parts come from below the ovary, the latter is said to be superior, and the flower is then distinguished as belonging to the Lily group. If the sepals and petals have combined at their base, and united themselves with the sides of the ovary, and therefore appear first from the top of the ovary, the latter is said to be inferior; and the flower is placed with the Daffodil family. Thus the daffodil, the snowdrop, and the snowflake all have inferior ovaries; while the lily-of-the-valley, the bluebell, and other lily types have superior ovaries. Apart from this difference, however, the flowers, when structurally considered, are very much alike.

Why, then, does the botanist attach so much importance to this apparently insignificant detail ? When considering the little florets of the wild camomile and the flowers of the primrose, I pointed out that when petals coalesce to form a tube it is a sign of advancement, for specialisation is then taking place. Now, although the coloured sepals and petals of the daffodil, the snowdrop, and the snowflake all appear to be free, yet in reality they are free only at their outer ends, for, as I have already explained, they have united at their 


\section{LIFE HISTORIES OF FAMILIAR PLANTS}

base with the sides of the ovary. Thus the botanist looks upon the Daffodil group as a higher and more evolved class of plants than the lilies; for, although some of the latter have joined together their petals and sepals, yet these all have superior ovaries. Indeed, to put the matter simply, we may say that the Daffodil family is an advanced group of lilies on account of its members possessing inferior ovaries.

By such simple stages of progression, of course, the higher and more complex lily types have been evolved. From the daffodils we turn to the Iris and Crocus family. In these two plants we find the floral parts arranged very much as in the case of the daffodils, but they possess only three stamens; a reduction in the number of their parts implying a still higher organisation, as I have pointed out in some of the previous chapters. In the gladiolus, which is a very advanced form of the Iris family, the circular shape of the flower has given way to a bilateral form - a specialisation that adapts the flower to admit special insects in a particular manner.

Now it only needs a moment's consideration of these bilateral flowers with the diminishing numbers of their floral whorls, to understand how the complex orchids (previously considered) with their bilateral flowers, three sepals, two petals, a single modified stamen, and one-celled inferior ovary, were evolved. Indeed, this brief study of the details of the daffodil's inferior ovary, tends to throw much light on the probable methods of r68 


\section{THE DAFFODIL}

evolution adopted by these highest of the trinary flowers while attaining their complexity, or at least it helps us to understand how their complex details could have evolved from the primitive flowers of their lily-like ancestors.

On account of its large entrance tube, or crown, the daffodil becomes a highly specialised individual of its group. In the case of the garden narcissus, it will be remembered that the crown is small and edged with red and orange colour, which features make the flower more attractive to insects and more readily guide them to where the nectar is stored. The daffodil's tube, however, is large and almost exactly fits the body of the humble-bee which visits it; and as the stamens shed their pollen from their sides facing the ovary, the bee cannot move between them and the ovary, as it seeks the nectar, without its legs and body becoming more or less completely dusted with the pollen.

Seeing that the pistil occupies a central position with its stigma just above the mouth of the tube and higher than the stamens, the bee is almost certain to convey to the stigma pollen from a neighbouring flower, as it alights upon it to enter the blossom.

When seeking nectar inside the flower, the bee is well below the stigma, and in making its way out it scrambles amongst the stamens lining the inside of the tube, and so accumulates a store of pollen about its legs and body to deposit upon the stigma of the next blossom it visits.

The tube or crown of the daffodil, therefore, 


\section{LIFE HISTORIES OF FAMIIIAR PLANTS}

makes fertilisation almost certain; and in view of the fact that the stigma matures just before the stamens, it is usually cross-fertilisation that is effected; for, early in the year when the daffodil opens its flowers, they are eagerly sought for by the humble- and honey-bees.

That which most excites our curiosity in connection with the crown of the daffodil is: How it ever came to be. Outside its own group there are no lilies or other related types that to my knowledge, give any hint of ever having possessed a similar vestibule to their floral chamber. We should observe that the daffodil's crown distinctly shows six sinuous lobes at its edges. We may reasonably assume, therefore, that the tube originated from six parts. Now, it is apparent that these parts could not be the three sepals and the three petals, because those organs still exist.

Turning to the garden narcissus we find that the crown there consists of only a wavy edging around the mouth of the flower. Let us imagine this same narcissus at an earlier stage, just before its petals and sepals had properly coalesced around the ovary. Then this wavy edging must have consisted of six little scales, one on each sepal and one on each petal. In the Pink family (which belongs to the dicotyledons, or class which bears fivefold flowers) we find frequent examples of such scale-like appendages on the petals, and the botanist terms them ligules. The Red and the White Lychnis (Lychnis vespertina and L. diurna), found almost everywhere in Britain, present 


\section{THE DAFFODIL}

familiar instances; and in the Comfrey (Symphytum officinale) we have an example of a tubular corolla with five similar scales, which, however, have not united.

Probably, then, the crown of the daffodil originated from a lost ancestor whose petals had similar ligules to those of the lychnis and the campion of to-day. Indeed, these members of the Pink family are probably now evolving a flower similar in arrangement to that of the daffodil. Their calyx lobes have in many genera already united, and the petals (although now free) are arranged so closely together within the calyx tube that they almost form a tube like that of the common primrose, and they bear similar spreading petals around its mouth. At the entrance to the tube the ligules form a little crown. Nevertheless, we should remember that the pinks belong to the group of dicotyledons, and the daffodils to the monocotyledons, and therefore, the plants are quite unrelated. Nature, however, often adapts features and devices that have proved successful in one group of organisms to entirely different groups ; but I shall have more to say on this point in Chapter XVII. 


\section{CHAPTER XVI}

\section{BUTTERCUP EVOLUTION}

AMONGST that great fivefold group of plants, or dicotyledons, as the botanist terms them, there are none more familiar than the buttercups of the meadows. The golden yellow of their flowers gives one of its greatest charms to an English landscape during early summer. Yet these flowers are amongst the most primitive that are found in the British flora.

Like the stonecrops, which I considered in Chapter XIV., the yellow buttercups have largely retained the fivefold arrangement of their flowers ; five calyx lobes, five petals, numerous stamens (some multiple of five), and likewise a pistil composed of many distinct tiny carpels, or ovaries. The Buttercup family, however, differs from that of the Stonecrops in the fact that many of its members have become very highly evolved. Indeed, a walk into almost any old-fashioned, country flower garden will provide the botanist with numerous examples of pedigree buttercups. Globe-flowers, hellebores, anemones, clematises, columbines, paeonies, larkspurs, monkshoods, and many other showy garden blooms, are buttercups with altered and evolved architecture ; and some of these specialised plants I will now consider. 
PLATE 72

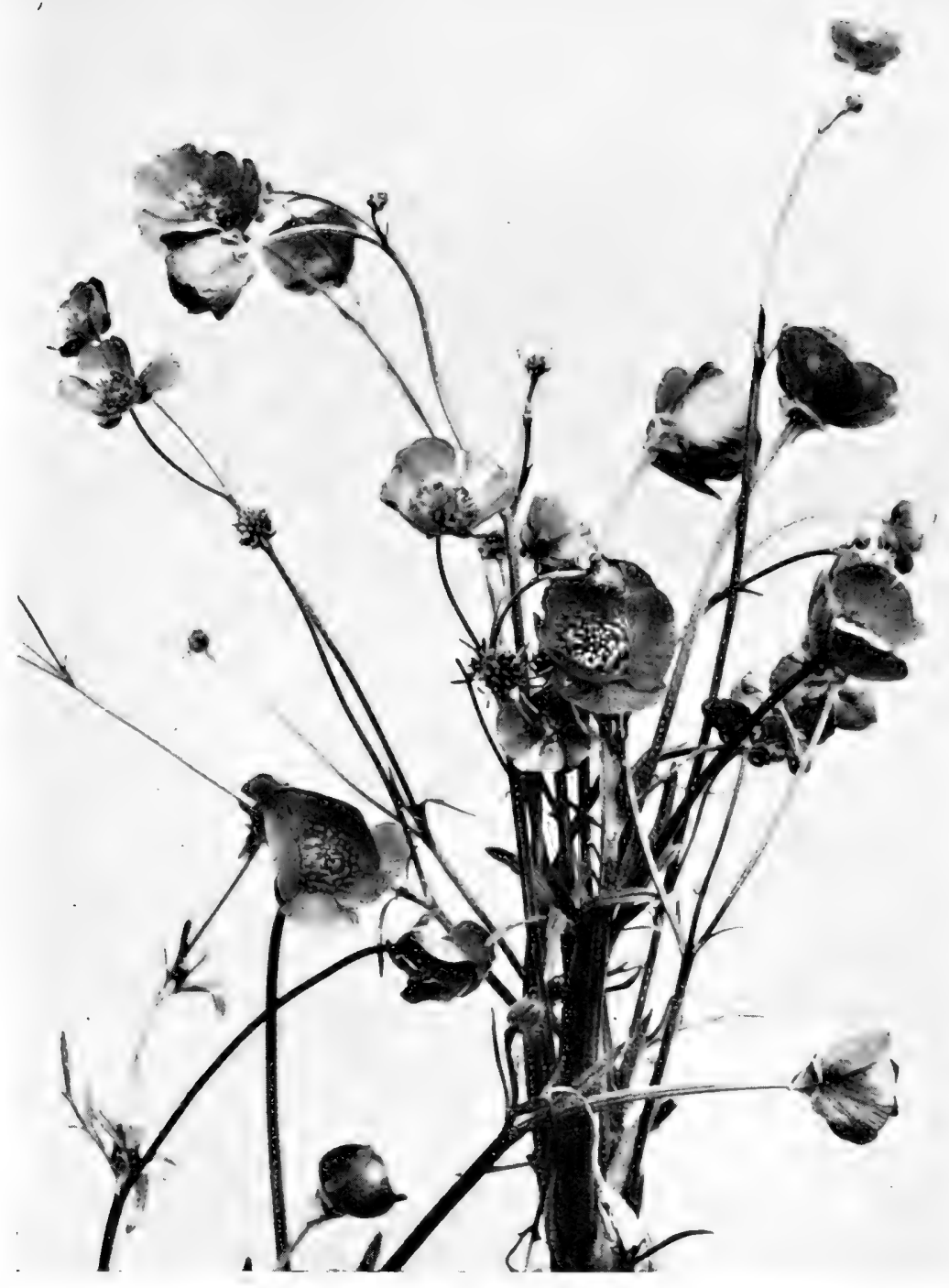

FIG. 101.-MEADOW AND BULBOUS BUTTERCUPS 



\section{BUTTERCUP EVOLUTION}

In the first place I will ask the reader to glance at Fig. Ior (Plate 72). There some of the familiar meadow buttercups are shown, but careful inspection of the illustration will reveal two distinct kinds of flowers. The buttercups that first appear and paint the meadows golden in early summer are a distinct species from those that develop a month later. The flowers of the two species, however, closely resemble each other, and as one species quickly succeeds the other, the change is but rarely observed except by botanists.

The smaller flowers in the illustration will be seen to have their five sepals pressed against their coloured petals, but the larger flowers have theirs held back away from the petals and pressed against the stem. A glance at the roots of the two species will reveal a more striking difference (Fig. 102, Plate 73). The root of the species bearing the smaller flowers is shown on the left, and that bearing the larger ones on the right. The latter is the Bulbous Buttercup (Ranunculus bulbosus), which is the first to appear in early summer. Its bulbous root explains its earlier appearance, for, throughout the winter months nourishing starches and food materials are stored therein which enable it to get an early start : and so it steals a march on its neighbour the Meadow Buttercup or Crowfoot (Ranunculus acris), which is forced to gather most of its building material as it requires it.

Also, the bulbous buttercup rarely needs to grow more than a foot in height, because at the time when it holds up its flowers the grasses have 


\section{LIFE HISTORIES OF FAMILIAR PLANTS}

not grown tall. The meadow buttercup, which comes later, has often to develop its stem to more than twice that height, otherwise its flowers would be hidden from the fertilising insects.

We have here, therefore, two plants whose close relationship is obvious and which grow in identical situations, but on account of slight variations in their structure to adapt them to varied circumstances with regard to the time of their appearance, they have become distinct species. In the same way there are some thirteen other species of British buttercups.all bearing a superficial resemblance, but all of which differ one from another very considerably in details. Only the botanist, however, stops to distinguish between the Wood Buttercup (Ranunculus auricomus), the Corn Buttercup ( $R$. arvensis), the Hairy Buttercup ( $R$. hirsutus), and the other species of the genera; yet a little study of their details reveals many interesting facts and sheds a wonderful amount of light on the reasons for their differences.

I have not the space at my disposal in this little volume to consider all the various species of the true buttercups, especially as I have to deal with their advanced relatives also in this chapter, but probably readers will find some pleasure in investigating on their own account amongst the different buttercup species. I will take one other example as a further indication of the methods which such investigation should follow.

Here, over the surface of the pond, is the I 74 
PLATE 73

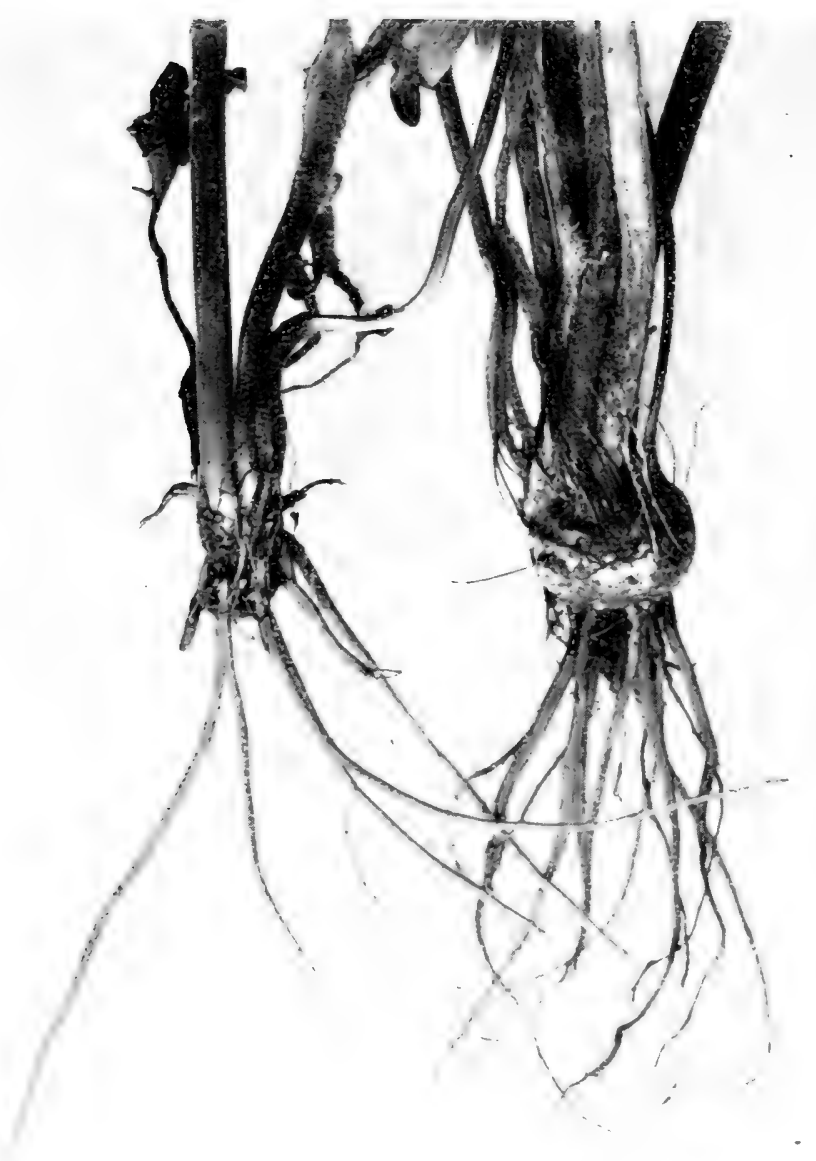

FIG. 102.-ROOTS OF THE MEADOW AND BULBOUS BUTTERCUPS 


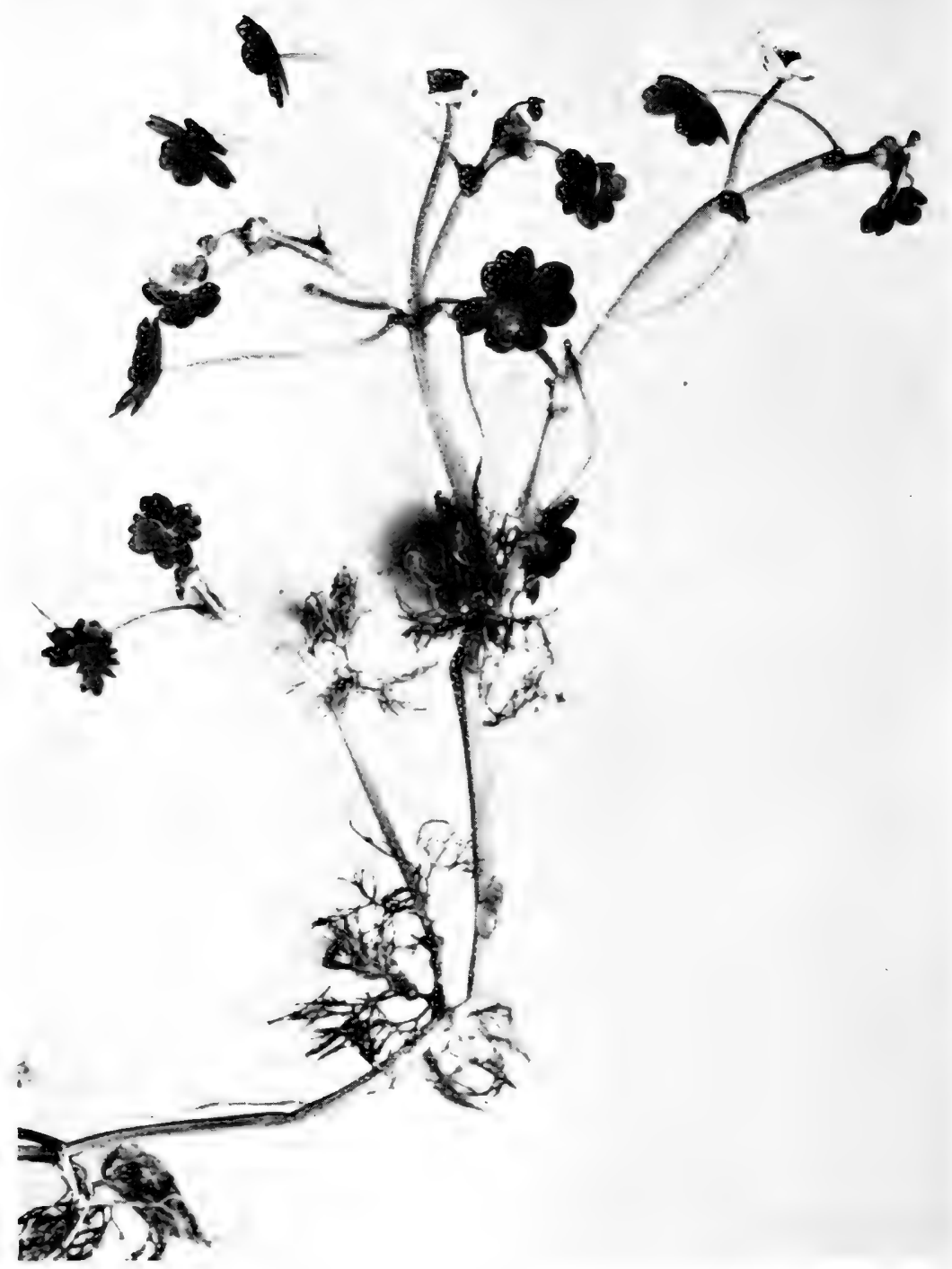

FIG, 103.-WATER BUTTERCUP WITH AQUATIC AND AERIAL LEAVES 


\section{BUTTERCUP EVOLUTION}

Water Buttercup (Ranunculus aquatilis)-a species that has developed aquatic habits. Probably at some remote period in buttercup history the land on which some species grew developed a tendency to become marshy and, as this tendency increased, only those buttercups would survive that adapted their structure to meet the altered conditions of their surroundings. In the water buttercup we have the survival of the fittest-a species that has so far modified its structure that it has become completely aquatic; now it flourishes in streams and ponds.

For a terrestrial plant to become aquatic means much adaptation of its structure, for the function of the leaves of land plants is essentially to absorb gaseous food from the atmosphere, and the submergence of their leaves would eventually mean starvation. In Fig. I03 (Plate 74) a branch of the water buttercup is shown, and it is there seen that it possesses two distinct kinds of leaf. Below they are divided into fine thread-like segments, and this form constitutes the submerged leaves. Above they are of a rounded type with cut and lobed edges, and these are the floating leaves.

Now the submerged leaves of habitual water plants are almost always small and narrow, often quite thread-like, because in this form they can best move with the currents and disturbances of the water, and are thus enabled more freely to search for and absorb the small quantities of carbonic acid and oxygen dissolved in the water. 
Some aquatic plants, like the water lilies, have developed air cavities in the tissues of their leaves, which cause them to float; then, as I have mentioned in Chapter IX., the leaves take the opposite course and spread themselves out into a rounded form on the surface of the water where they are fully exposed to the atmosphere (Fig. I I5, Plate 83); the rounded form being the outcome of lack of competition for space.

Now, the water buttercup holds a unique position amongst aquatic plants for it has, as it were, taken a hint from both the ordinary types of aquatic plants; it has developed leaves of fine segments like those of the submerged species, and also floating leaves. It is true that its upper leaves often stand above the water instead of floating directly upon its surface, but we must not overlook the fact that the water buttercup has had to modify its original structure, and that at present it is comparatively young at the business, so to speak. We have only to compare the shape of the upper leaves with those of the buttercups of the field to see readily how the deeply-divided segments of the family type of leaf are being filled in to produce a rounded form. Then if we observe how, when the leaves reach the surface of the water they buoy up the stems, the path that the water buttercup is pursuing is obvious.

Two further points we should notice with regard to this species. First, that its petals have become almost white, only a small patch of their original yellow still remaining near their base. 


\section{BUTTERCUP EVOLUTION}

This change has doubtless been brought about owing to adaptation to a different class of insects, which the watery surroundings would account for. The second point is that the plant is entirely free from hairs.

Now, many of the buttercups possess hairy stems and leaves, because they are troubled by creeping insects, such as ants, which climb their stems and rifle the flowers of their honey without pollinating their stigmas. Nothing baffles such depredating insects so effectually as a thicket of hairs. You have only to examine the turned-back and hairy calyx of the bulbous buttercup as it presses closely against the stem to see how perfectly it bars the entrance to the flowers from below-no ant can reach their nectar. The water buttercup has no such protection; surrounded by water, as its stems are, no creeping insects can reach its flowers, only the winged and proper fertilising insects can approach its nectar; hence hairs on its stems or leaves would be superfluous.

Thus we see that, even amongst the buttercups themselves, each species possesses particular characteristics that are of service in its economy; also, it is obvious how external conditions influence the course of the evolution of the species. The same facts, too, explain how the higher types, such as the Globe-flower (Trollius europaus), the Green Hellebore (Helleborus viridis), the Christmas Rose ( $H$. niger), the Marsh Marigold (Caltha palustris), the Anemone (Anemone nemorosa), the Traveller's Joy (Clematis vitalba), etc., came 


\section{LIFE HISTORIES OF FAMILIAR PIAANTS}

to be. Each of the plants mentioned had a simple buttercup origin, but so altered have they become that we no longer recognise them as buttercups.

The distinguishing features of the typical buttercup flower are these: it should have five separate sepals, five separate petals, numerous stamens in whorls of five, and numerous carpels, or ovaries, also in whorls of five, and the stamens, petals, and sepals should all arise below the central group of ovaries. Also, each of the petals has, near its base, a simple honey gland covered with a tiny scale.

Now, in some of the more evolved genera of the Buttercup family, as in the clematis (Fig. 104, Plate 75), the anemone, and the marsh marigold, we find but a single coloured whorl around their stamens and ovaries. Apparently these flowers have lost the five green sepals of their calyx; however, that is not the case, it is their petals which have disappeared. In the course of their evolution their petals have become more and more insignificant until they have been completely lost. But the most curious part of the matter is that with the loss of their petals the sepals have become coloured-i.e., taken on the functions of the petals.

This feature of the suppression of the petals and the promotion of the sepals is, when one comes to think of it, very extraordinary. Why should several genera in the Buttercup family that required coloured display to attract fertilising insects, 


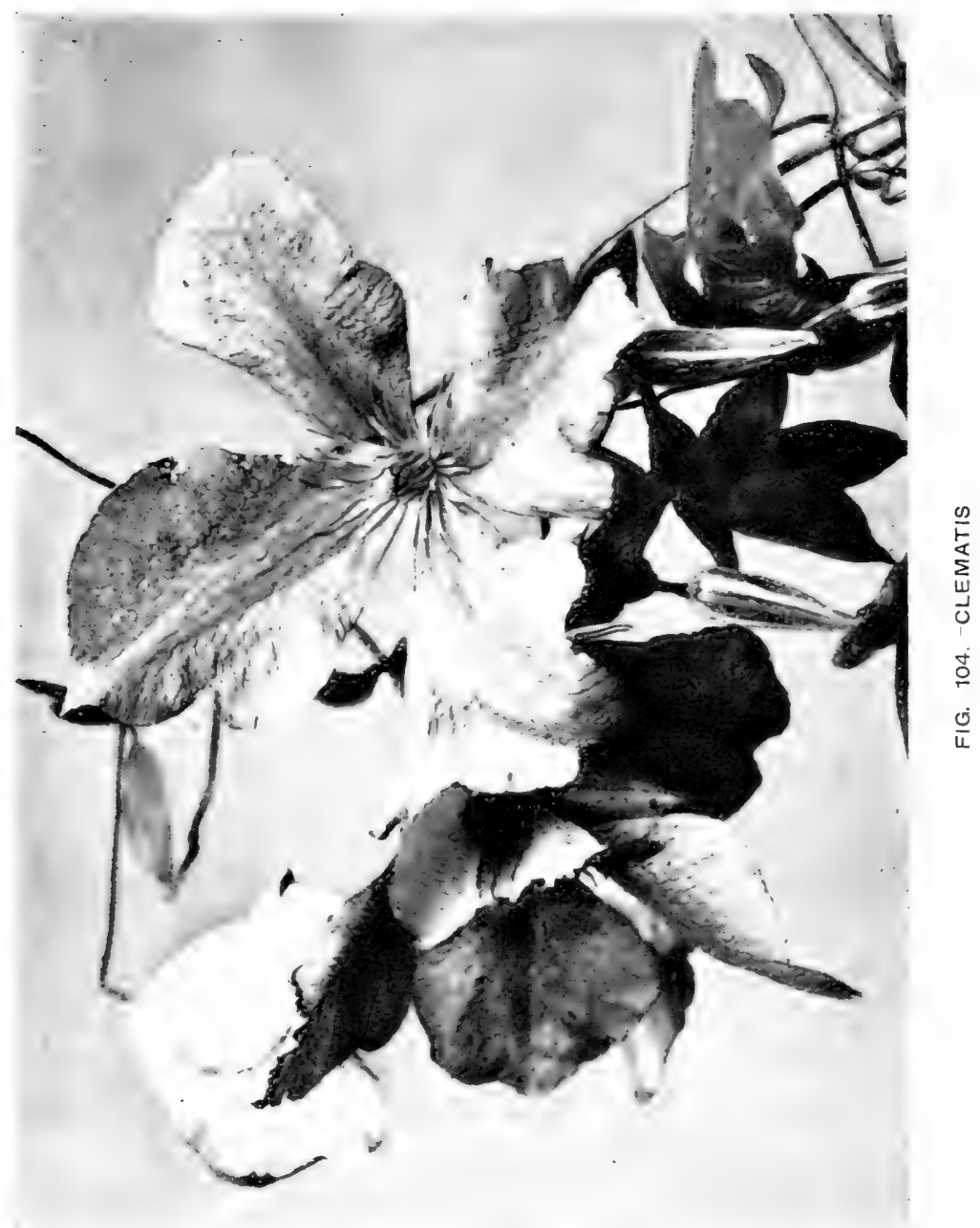




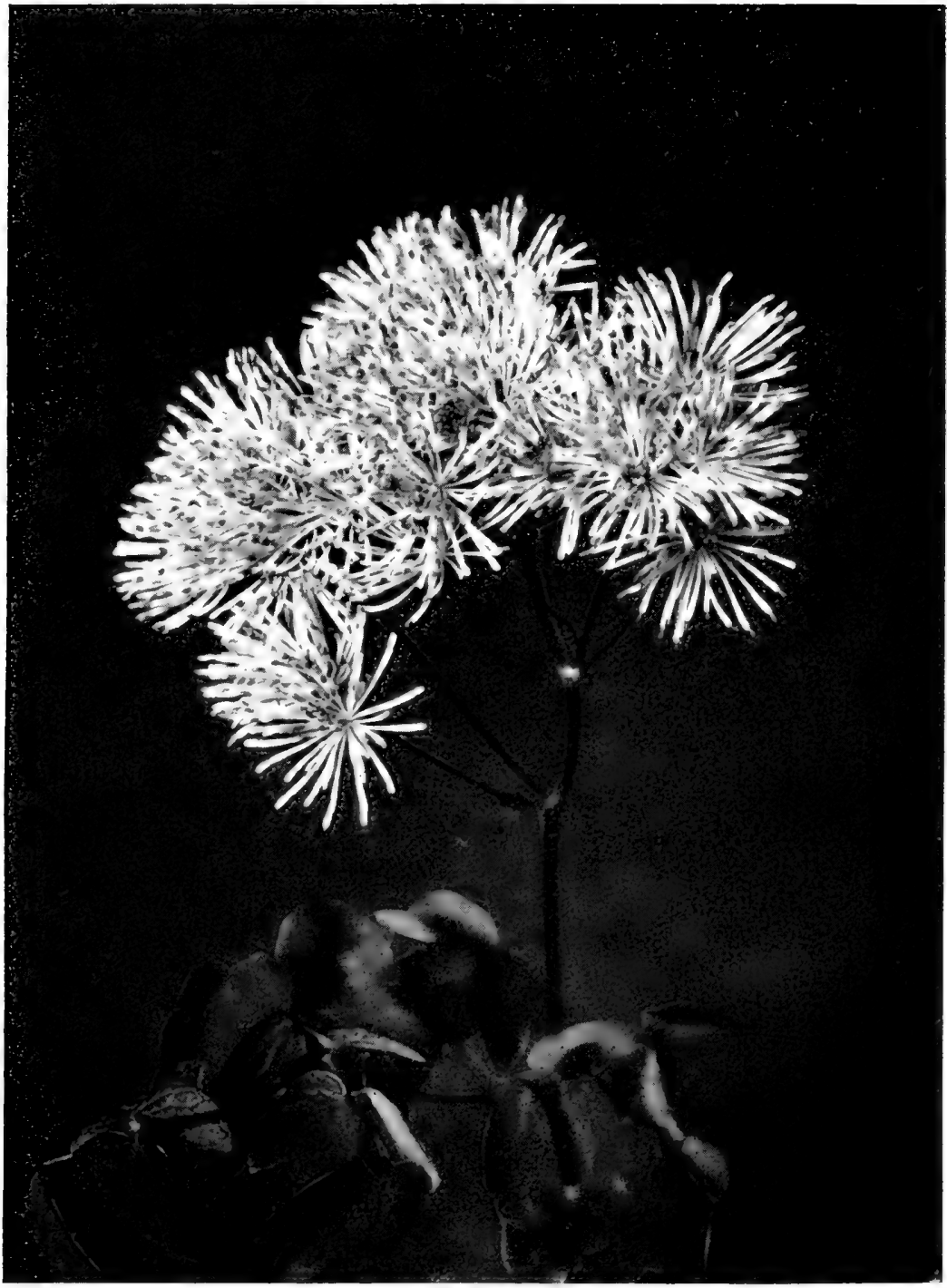

FIG. 105.-COLUMBINE-LEAVED MEAdOW RUE 


\section{BUTTERCUP EVOLUTION}

suppress their coloured petals merely to promote their sepals into similar coloured organs? That is a point which, so far as I know, seems uniformly overlooked in explanatory botanical works.

The explanation can be found, I think, from analogy in comparing these with other members of the family group. I have before mentioned that the typical or simple buttercup has a little honey gland near the base of each petal. Now, if we turn to the garden hellebore and the globe-flower, we find that these flowers, like the clematis and the anemone, possess a coloured calyx ; but they also have petals besides. However, these petals are dwarfed and serve only as nectaries. That fact is the key to the explanation of the coloured sepals. Originally, as seen in the buttercups, the nectaries were insignificant little honey-secreting glands, and the globe-flower and the hellebore in developing their nectaries necessarily had to sacrifice their petals, for the nectaries were part of the petals. Colour and size were then largely evolved in the sepals to advertise the developing nectaries.

So far the explanation is simple enough. How came the anemone and the clematis, though, each to possess a conspicuously coloured calyx and yet have no nectaries? All flowers that do not produce honey are rich in pollen, usually having numerous stamens; dog-roses and poppies are familiar examples. As we have seen, one of the chief characteristics of the Buttercup family is its numerous stamens. Now there are many polleneating and pollen-collecting insects, and these 


\section{LIFE HISTORIES OF FAMILIAR PLANTS}

naturally patronise flowers with numerous stamens. The original buttercups, however, were well equipped, possessing both numerous stamens and also nectaries, but as the genera came to differ more and more from the ancestral form, the characteristic features of each resulted in differentiating the patronage from their insect visitors; and since in some instances the pollen was appreciated more than the nectar, in such cases the nectaries slowly lost their function, became obsolete, and eventually disappeared.

So the clematis now depends entirely upon its scent, its four or five coloured sepals, and its pollen to attract fertilising insects. In the anemone, however, insects have been observed to pierce some easily perforated tissues at the base of the flower and suck its juices. Also, in the case of the marsh marigold, which, likewise, has a coloured calyx, honey is secreted amongst the carpels. I am inclined to think that both these developments have appeared since the original nectaries were lost, as I suggested in the case of the willow catkins in Chapter X. Probably as time has passed some of the pollen-feeding insects have become scarce, or have changed their habits, and now the marsh marigold and the anemone are again developing their dormant trait and alluring insects by means of honey and liquid food, but from new nectaries, as their original ones, together with their petals, were lost.

In this manner the anemone and the marsh marigold may probably save themselves from 180 


\section{BUTTERCUP EVOLUTION}

degeneration. When flowers begin to lose their petals there is always the danger of their degenerating into habits of wind-fertilisation. Indeed, there is some considerable reason for thinking that even now the clematis is developing that habit; while the Meadow Rues (Thalictrum), in some of their species, already depend upon the wind as their pollen-carrier.

The meadow rues have, like the anemone and the marsh marigold, lost their petals and nectaries, but they have gone farther than this ; their sepals have dwindled into greenish scales which are now only tinted with the pink and yellow colours they once possessed. In the Lesser Meadow Rue (Thalictrum minus) the flowers are arranged in a loose panicle, and each one is suspended on a slender stalk, so that the wind can readily shake its pollen from the long stamens that project beyond the calyx; indeed, the whole floral arrangement has become well adapted to the requirements of wind-fertilisation.

In some of the Meadow Rue species the stamens have become large and showy, like those of the willow catkins previously considered, and in this way insects are attracted to their pollen. Also, as if to assist this purpose, when at the height of their showiness the sepals are thrown completely off, whereby the coloured filaments of the stamens are exposed. The familiar Columbineleaved Meadow Rue (Thalictrum aquilegifolium) shown in Fig. I05 (Plate 76), and common in country gardens, exhibits these features. Thus I8I 


\section{LIFE HISTORIES OF FAMILIAR PLANTS}

some of the species are, as it were, struggling to regain their lost ground.

Then, on the other side, there are the aristocrats of the Buttercup family; those genera which have retained and evolved their original parts to a higher degree of perfection. These begin with the Columbine (Aquilegia vulgaris) which is commonly cultivated in gardens (Fig. I06, Plate 77).

The columbine has attained the highly-evolved blue colour, which denotes that it seeks pollination from the higher insects, as bees and butterflies. Its petals have been converted into horn-like spurs, knobbed at their ends, in which honey is stored. Also the five sepals have become coloured like the petals, and are displayed alternately with the open mouths of the five honey tubes of the petals.

Thus the columbine has evolved its primitive nectaries to a high degree, for now the honey can only be reached by insects that possess a proboscis sufficiently long to reach to the end of the tube. The stamens and stigmas project from the centre of the flower and serve as a landing-stage for the fertilising insects (Fig. I06, Plate 77). Its stamens come to maturity first, so that their pollen is removed by the body and the legs of the bee as it turns about to search each of the five honeybearing petals, and is then carried to older flowers whose stigmas have ripened; thus cross-fertilisation is effected. The ovaries number only five, and each one contains several seeds-another sign 


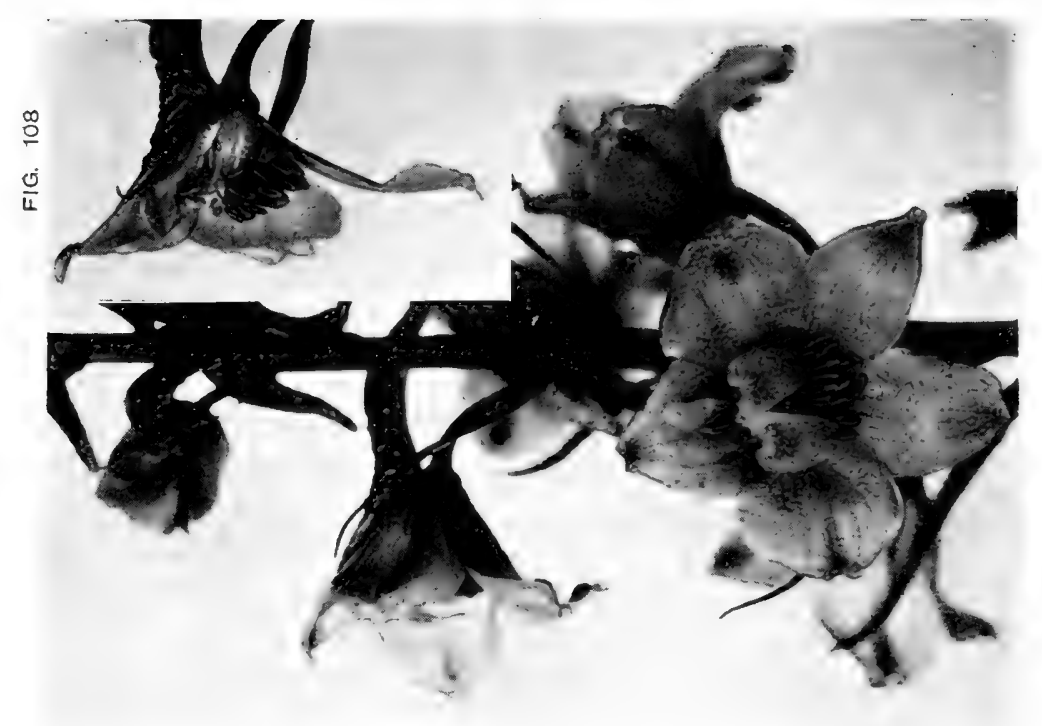

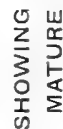

z岌

용

एं

แ

造

离

㟧

I

1. 2

옹

ए

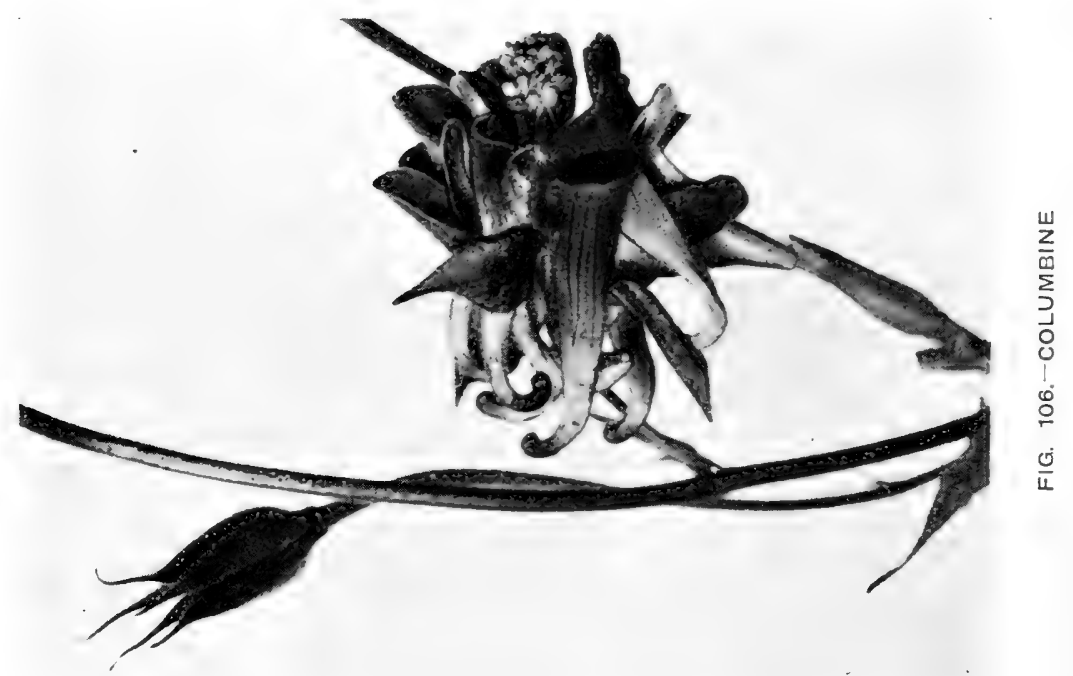




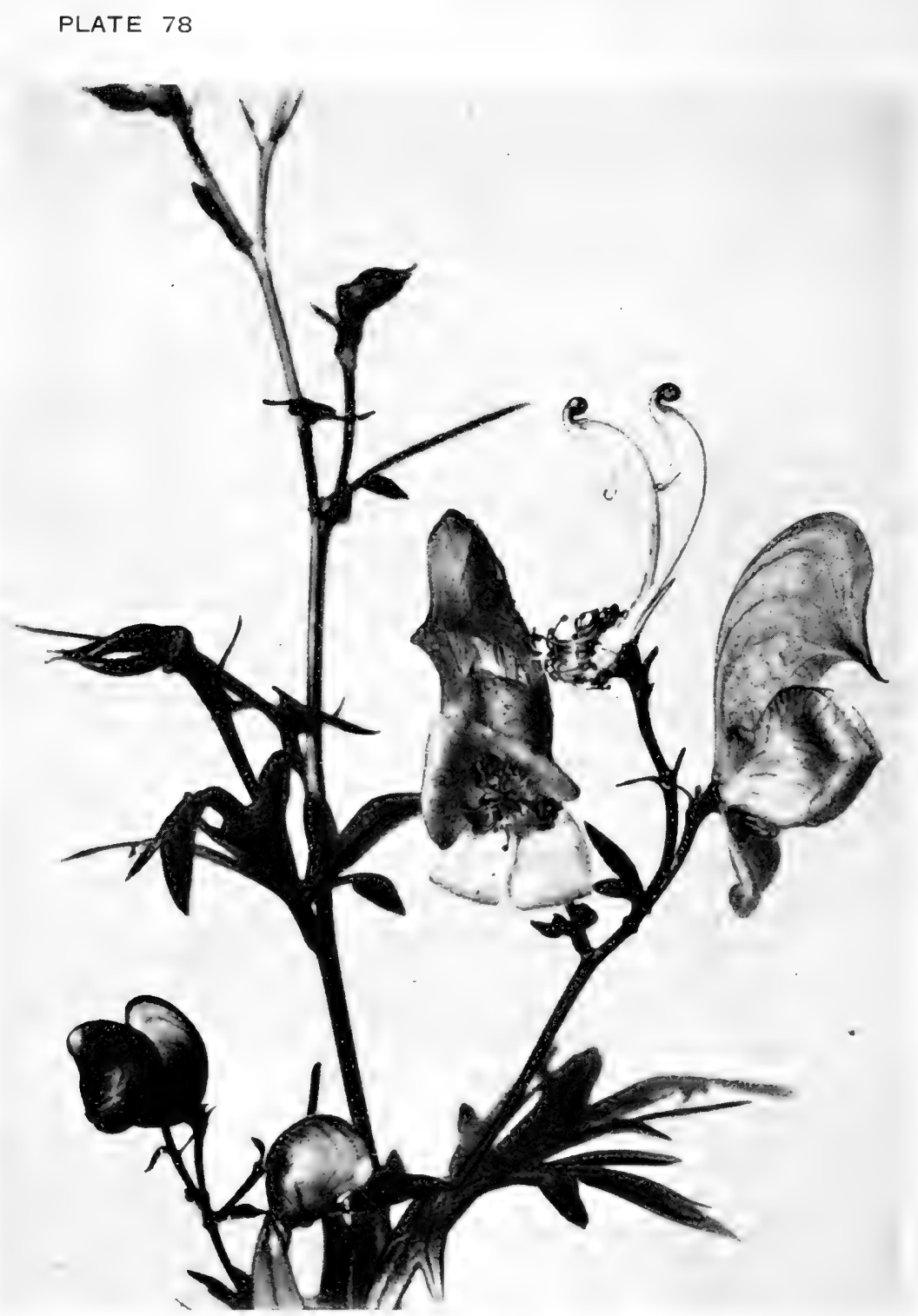

FIG 109.-MONKSHOOD FLOWERS AND THEIR NECTARIES 


\section{BUTTERCUP EVOLUTION}

of advancement, for with the more complex adaptations to insure fertilisation the numerous singleseeded carpels characteristic of the family can be dispensed with. This latter feature is conspicuous in all the advanced types; indeed, in the highest forms there are rarely more than one to three carpels, so secure are they of fertilisation.

The Larkspurs (Delphinium) show a still higher evolution. Their calyx is coloured blue, is large and showy, and prolonged into a spur at its base. There are only two petals in the British species, and these have both developed into spurlike nectaries, and even these have combined at their base. The spurred nectaries are enclosed within the calyx spur; and in this way the honey is protected from short-tongued bees which cannot legitimately reach the nectar, but which, instead of entering the flower and assisting in its fertilisation, would bite open the spur to get at the honey. It may be, too, that the calyx spur possesses some distasteful property. Its tissues are certainly tougher for the bee or wasp to penetrate than the nectary tubes would be ; at all events, it is discouraging to such robbers to find that, after all their work, there is another spur within.

Why is the larkspur more highly evolved than the columbine, seeing that it has lost three of its petals while the columbine has retained its five? Well, the larkspur has lost three of its petals because the complex adaptations of its structure have permitted it to economise in this manner. In Chapter XI. we observed how the one stamen of 


\section{IIFE HISTORIES OF FAMILIAR PLANTS}

the wild orchid performed its functions even more successfully than the six of its remote ancestors; likewise with the larkspur's nectaries, in its present arrangement its two combined petals are of greater service in its floral economy than its original five would be.

The loss of its three petals is a very different matter to the similar loss in the case of the anemone or the clematis, for the petals of these plants were lost by a gradual degeneration. The larkspur, however, has developed two of its nectaries at the expense of the other three; its flowers have evolved a tendency to lose their circular form and become one-sided (a feature that denotes considerable evolution), and in this form of flower nectaries arranged all round the floral structure would be superfluous.

In the present arrangement the bee can only thrust its proboscis into the nectaries in a particular manner, and as the stamens mature they each turn up and meet the bee's proboscis as it seeks the honey from the base of the nectaries. After shedding their pollen they again bend down and the solitary stigma takes their place, for the larkspur is so certain of fertilisation that it often reduces its carpels to a solitary one containing several seeds.

The methods of fertilisation can be well seen in the case of the garden Larkspurs. A front view of one of the flowers of these is shown in Fig I07, Plate 77 (Delphinium elatum), which shows the opening through which the bee inserts its proboscis. 


\section{BUTTERCUP EVOLUTION}

In Fig. 108, Plate 77, (inset), a section view of the flower is shown, where the stamens are seen bending upwards into the opening as they mature. As the stigma does not ripen and bend upwards until all the stamens have ascended and returned, it need scarcely be added that it is cross-fertilisation which is effected.

What I have said above applies in a large degree to the Monkshood (Aconitum Napellus), only that here the bilateral feature of the bluecoloured calyx has still further evolved; while the two nectaries have become much more complex, their honey-bearing parts being hidden in the upper helmet-shaped sepal. In Fig. Io9 (Plate 78) various aspects of the flowers are shown, including one from which I have removed the coloured calyx and exposed the two curious nectaries which, as a little observation will show, only humble-bees can reach - so evolved and specialised have these floral structures become.

Thus the complex structures of these highest buttercup types are the direct outcome of the selective tastes of the various insects that have most profitably patronised them in the course of their evolution; by their unconscious agency have the various and complex forms been moulded. Thus originated all the choice Buttercup species man now delights in cultivating under other names; cultivation has enlarged their merits, the foundations of which were laid, however, ages ago. 


\section{CHAPTER XVII}

\section{SOME FLORAL ADVERTISEMENTS}

THE more one studies floral structures the more obvious does it become how perfect is the specialisation of each for the visits of the particular insects that best convey their pollen from bloom to bloom. There are reasons for even the most insignificant detail in their mechanism; every allurement is offered to attract their special insect guests. Look at the tall racemes of the Foxglove (Digitalis purpurea) shown in Fig. I Io (Plate 79) Each axis stands from two to four feet in height, and, arranged along its length, its drooping bellshaped flowers open from below upwards. The foxglove is never so comfortable as when backed closely by the edge of a wood, or even the roadside hedge; there its tall flower stems are sheltered from the wind and run little risk of getting broken. That protection, however, presents a problem; in such a situation one side of the plant is necessarily shaded. The humble-bees, for which alone the foxglove flowers are designed, love the sunlight; there lies the difficulty. Thus the foxglove's flower stem is what the botanist terms a simple, one-sided raceme. Or, to put the point more suggestively, the foxglove turns all its bell-shaped flowers from the shady hedge- 


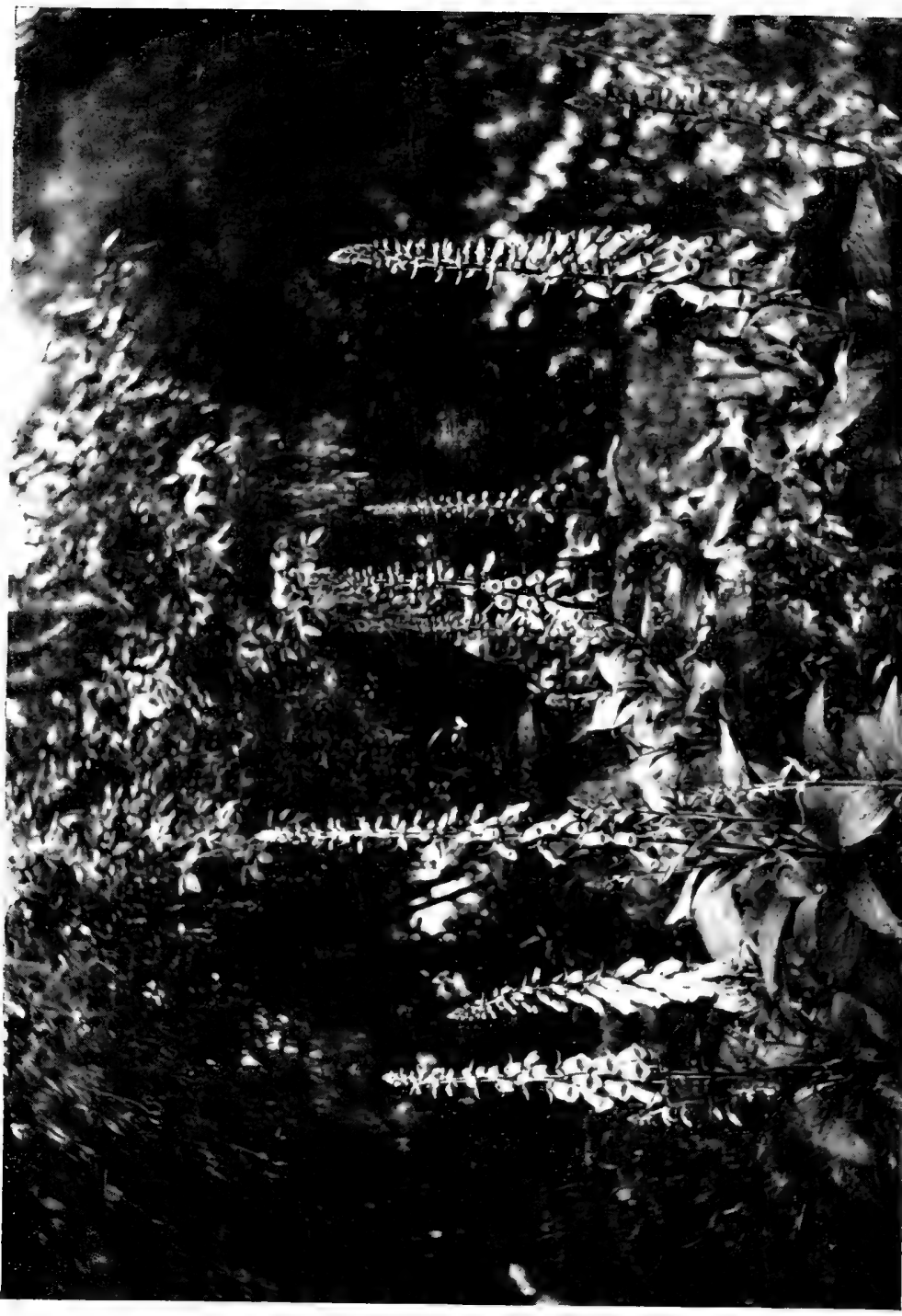




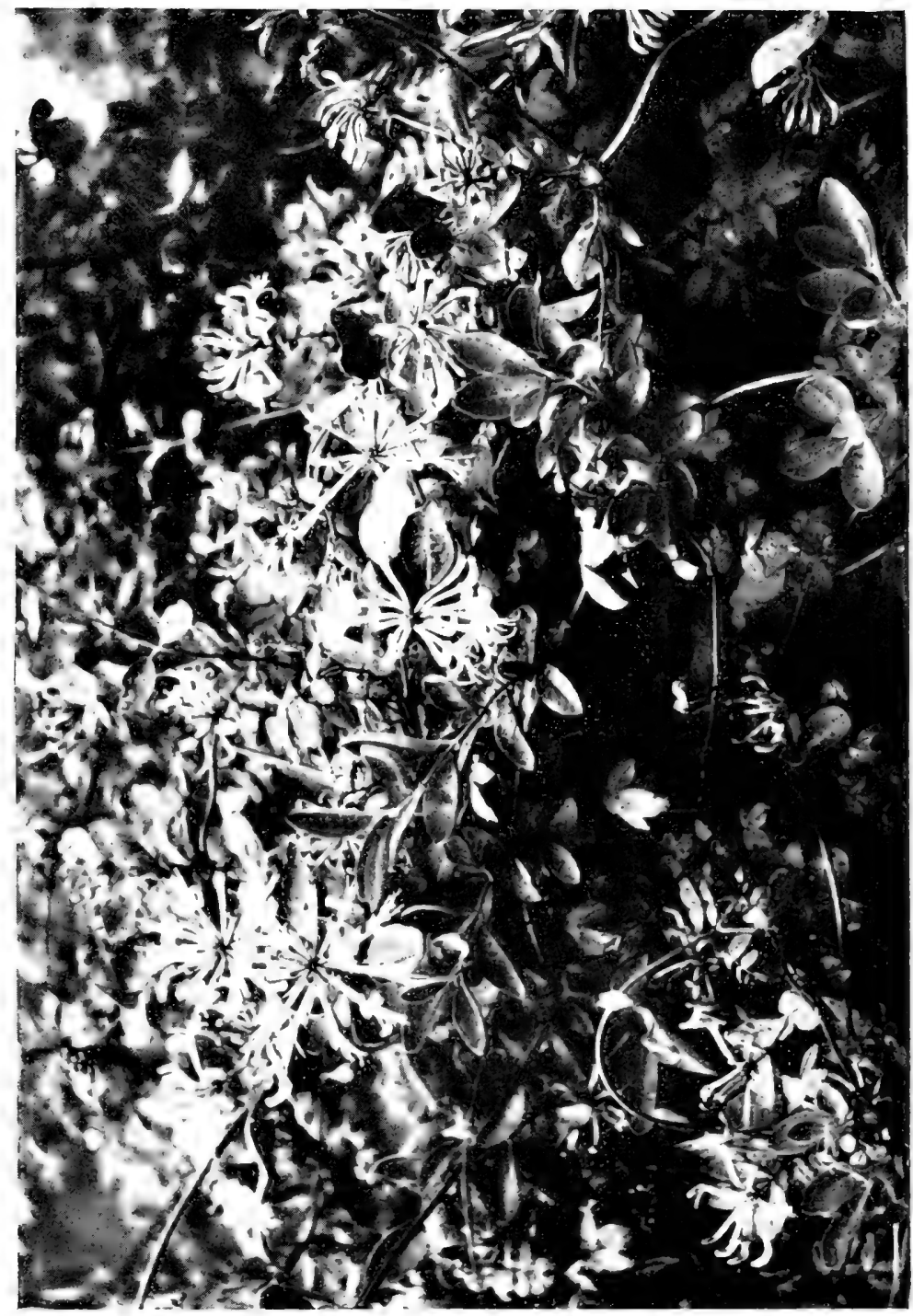




\section{SOME FLORAL ADVERTISEMENTS}

row to the sunny meadow where the large humblebees are seeking nectar.

There the tall stems stand, their purple bells contrasted against the deep green of the dark woodland, the bank, or the hedgerow - a huge and striking advertisement.

Just as the business man seeks the site that best exhibits the posters advertising the merits of his wares to his clients, so do plants offer every temptation and inducement to their customers. Competition in the plant world is every bit as keen as it is in the trade warfare of man.

The foxglove has adapted each of its flowers to fit the body of a burly humble-bee. Each flower is suspended mouth downwards and turned to the sunlight to receive its (paying) guest. The four stamens are perfectly arranged in the upper part of the bell to dust the hairy back of the bee while it seeks the nectar. Only the body of a humblebee is large enough to brush against the stamens in the younger flowers and the stigma in the older ones, and thus effect cross-fertilisation. Hence, the down-turned tube of each flower is perfectly adapted for the alighting and reception of these large bees; while to other insects which endeavour to reach the honey the tube presents enormous difficulties. It is obvious then that the bold show of foxgloves that skirt the wood and the hedgerow side, is simply a huge advertisement designed exclusively for humble-bees.

Such specialised floral advertisements are very common; while the foxglove advertises for 187 


\section{LIFE HISTORIES OF FAMILIAR PLANTS}

humble-bees, other flowers want moths and butterflies, others beetles, and still others flies. Also, just as the foxglove advertises for a particular class of bees, so do other plants advertise for certain kinds of moths. The Honeysuckle (Lonicera Caprifolium), (Fig. II I, Plate 80), for example, crowds together its tubular flowers into a cluster, thereby making a greater display to contrast against the hedgerow foliage. The flowers are richly scented and pale in colour, because these features make them attractive to the nightflying moths for which they are specialised.

The unopened flower-buds are directed upwards, but, as they mature, each tubular blossom bends down and the lower lobe of the tube then spreads out, the others quickly following. Within two or three minutes the flower has opened and its stamens are spread ready to receive the fertilising moths. Its scent is faint until the approach of evening, when it becomes powerful, and so it remains until well upon midnight, for that is the period during which its winged visitors come to feed.

The particular kind of insects for which it caters are known as hawk-moths. These moths, while poised on their rapidly vibrating wings, sip nectar from the depths of the flowers by means of their long tongues or probosces. Of course, such insects require no platform to alight upon; and therefore the blossoms provide none.

How powerful a factor the scent of the honeysuckle is in attracting insect visitors is instanced I88 


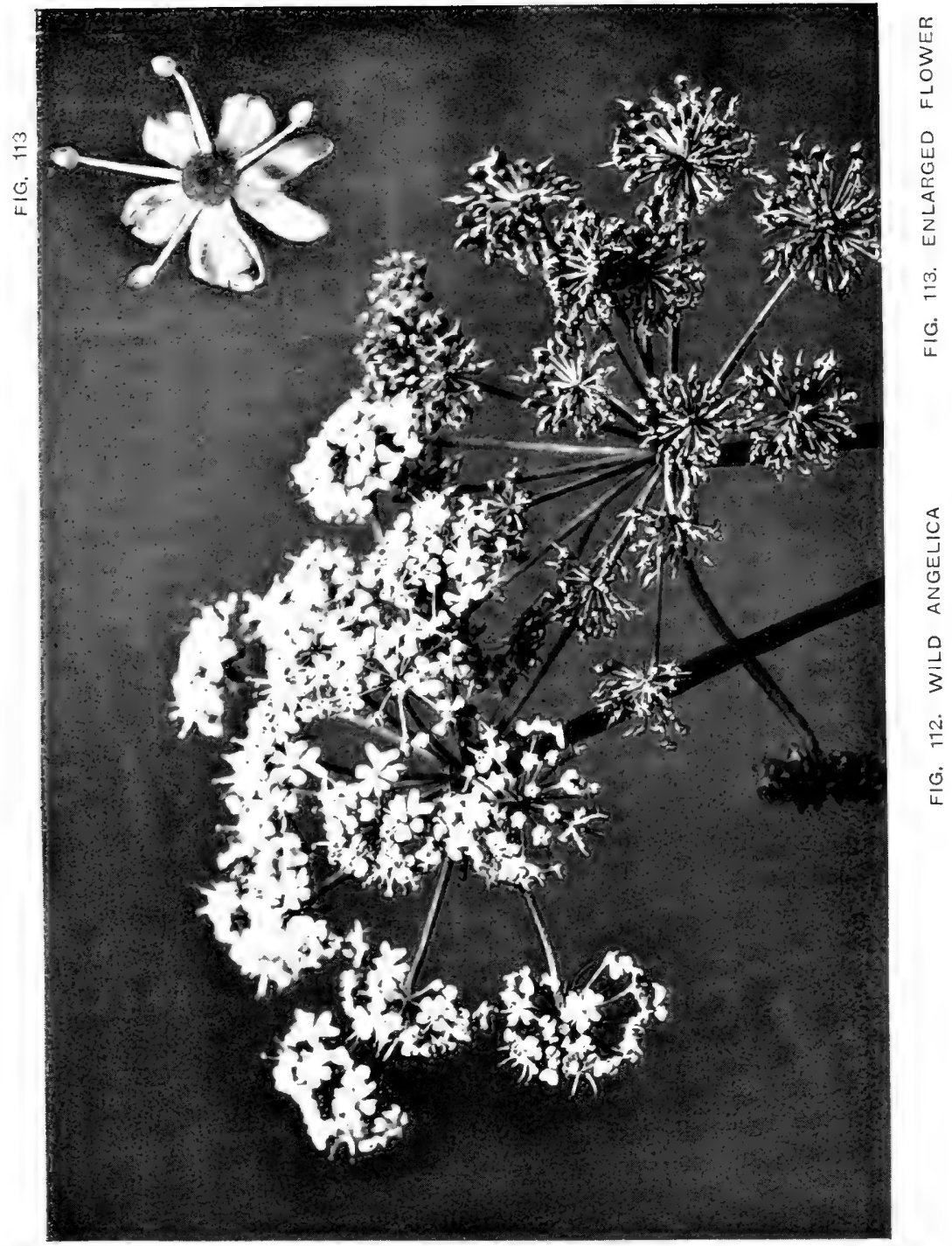





\section{SOME FLORAL ADVERTISEMENTS}

by Kerner, who relates how he found a convolvulus hawk-moth resting near some honeysuckle plants, and removed it to a garden three hundred yards away, first marking it with cinnabar so that he could recognise it again. "When twilight fell," he states, "the hawk-moth began to wave the feelers, which serve it as olfactory organs, hither and thither a few times, then stretched its wings and flew like an arrow through the garden towards the honeysuckle. Shortly afterwards I met the hawk-moth with the cinnabar mark hovering over these flowers and sucking the honey. It had flown straight to the plant, and must have been able to smell the scent of the flowers even at so great a distance."

Of course, there are the general advertisers; flowers that keep open house, as it were, and cater more or less for all. The common yellow buttercups are flowers of this order. Also another example is that of the familiar White Water Lily (Nymphea alba), illustrated in Fig. II5, (Plate 83). I am inclined to think, however, that this plant somewhat favours small beetles and flies that fly, in the sunlight, above the surface of the water. At first glance its pure white colour might incline one to think that it catered for night-flying moths. A little observation, though, will show that at evening the flowers close, and that they open again between six and seven in the morning; also that on dull days they remain closed throughout the day. Evidently, therefore, it is sun-loving insects that the water lily courts; at all events, its I89 


\section{LIFE HISTORIES OF FAMILIAR PLANTS}

white colour, contrasted with the black surface of the water, and its large size, are striking advertisements for visitors.

Where the individual flowers are very small they are usually massed together so as to present a bold show. The Umbellate family offer conspicuous examples of this. The Wild Angelica (Angelica sylvestris) (Fig. II2, Plate 8I) will serve as a type. Here flies, wasps, and other short-tongued insects are catered for; they roam over the mass of flowers sipping their exposed drops of honey and rubbing amongst the stamens and stigmas as they feed.

Fig. II3 (Plate 8I) is a magnified view of one of the flowers from the edge of the group, showing how its outside petal is enlarged. This unsymmetrical feature is commonly found in the outer flowers of the groups in this family; and its purpose is obvious. By extending the petals of the outer flowers the mass is made more conspicuous. So crowded are the flowers that only the outer ones can successfully develop this onesidedness. In the corymbs of the familiar garden Candytufts (Iberis) the same feature appears; the plants, however, belong to entirely different families.

In the chapter on the Daffodil I called attention to the fact that Nature had, as it were, in constructing the flowers of the Pink family, worked on a similar principle to that employed in the case of the daffodil. Now this development of enlarged outer flowers, likewise, may be found 


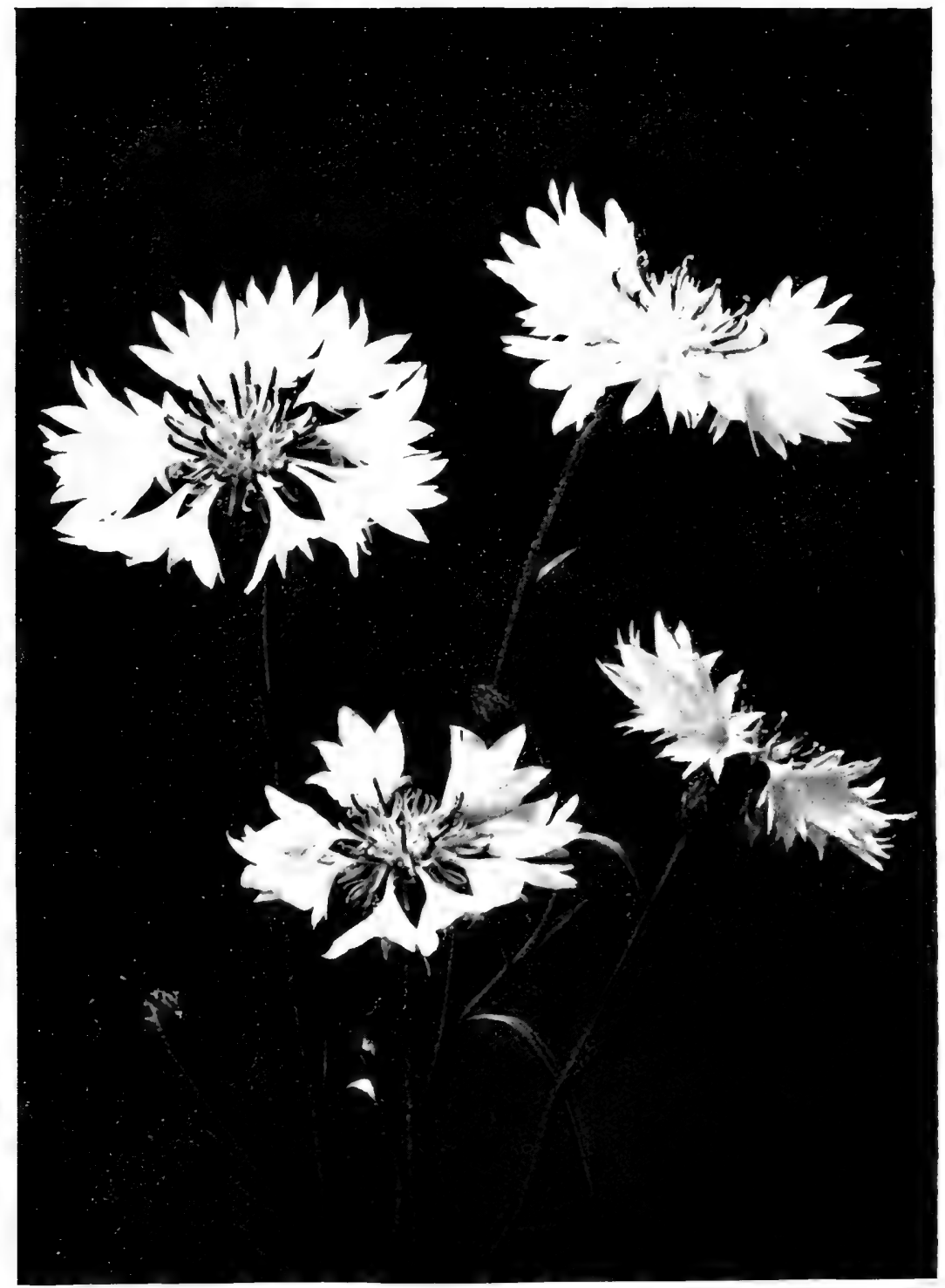

FIG. 114.-CORNFLOWERS 
PLATE 83

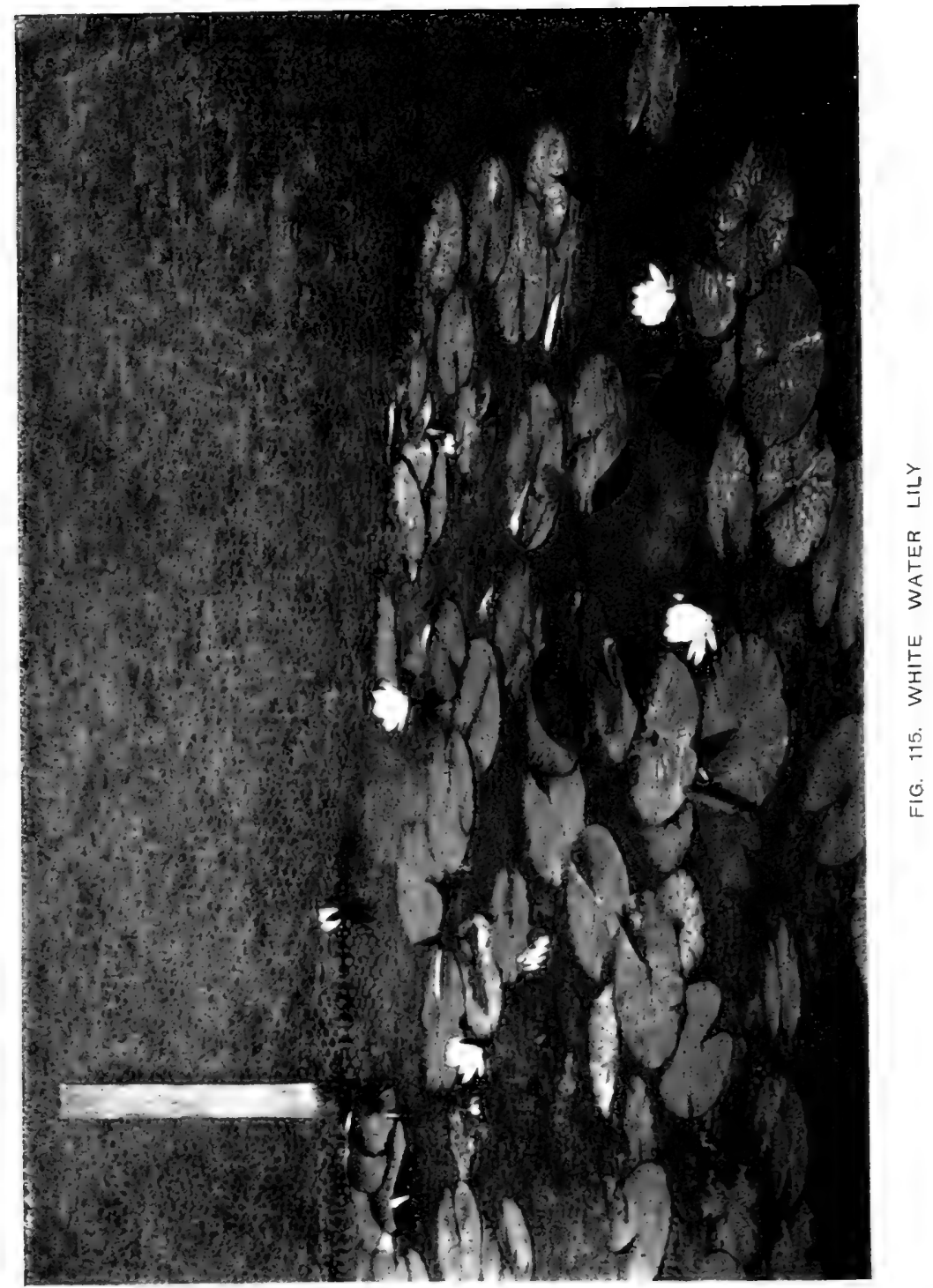




\section{SOME FLORAL ADVERTISEMENTS}

existing in a great number of entirely different families of plants.

In the Umbellate family the feature is sometimes carried beyond the stage of enlarged petals ; the outer flowers themselves often being of a larger size. The frontispiece to this volume shows a very striking development of this order belonging to quite a different family. The Guelder Rose (Viburmum Opulus), which belongs to the Honeysuckle family, has, like the wild angelica, crowded together its insignificant flowers, but it has carried the principle of utilising the outer whorl for advertising purposes to a much greater perfection. It has not only enlarged the outer flowers, but has sacrificed their stamens and ovaries to that end; the flowers are now neuter blossoms, bearing neither stamens nor stigmas, and are used entirely for display, to advertise the insignificant seed-bearing flowers within the group. How effectively they perform their function the frontispiece well shows.

It will be remembered that in the crowded head of florets of the wild camomile the outer ones showed a one-sided development of their petal tubes at the expense of their stamens. Now in some other members of the same Composite family further specialisation in that direction has gone on until the same result has been attained as in the guelder rose.

In the common Cornflower (Centaurea Cyanus), (Fig. II4, Plate 82), the outer florets of the head consist of large and showy neuter blossoms, which 


\section{LIFE HISTORIES OF FAMILIAR PLANTS}

have entirely sacrificed their stamens and ovaries in the development of their large corollas.

Thus we find an advertising device which has proved successful in one family imitated in several others; but the various families all agree in one point, viz., that they have small and insignificant flowers which offer honey in return for insect-fertilisation-hence the advertisement. 

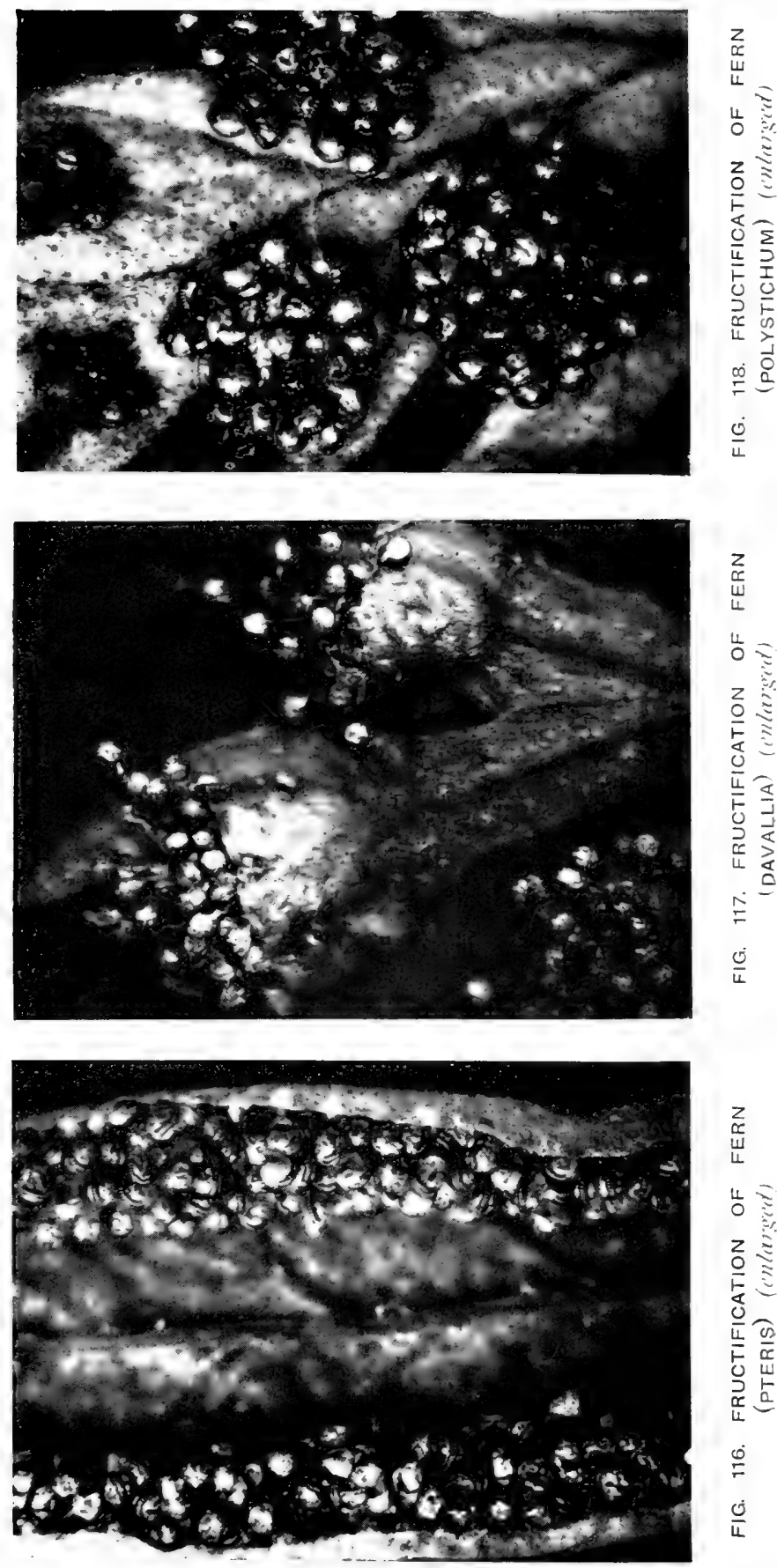

采

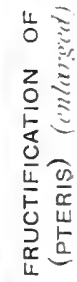

$\stackrel{0}{\circ}$

एั 


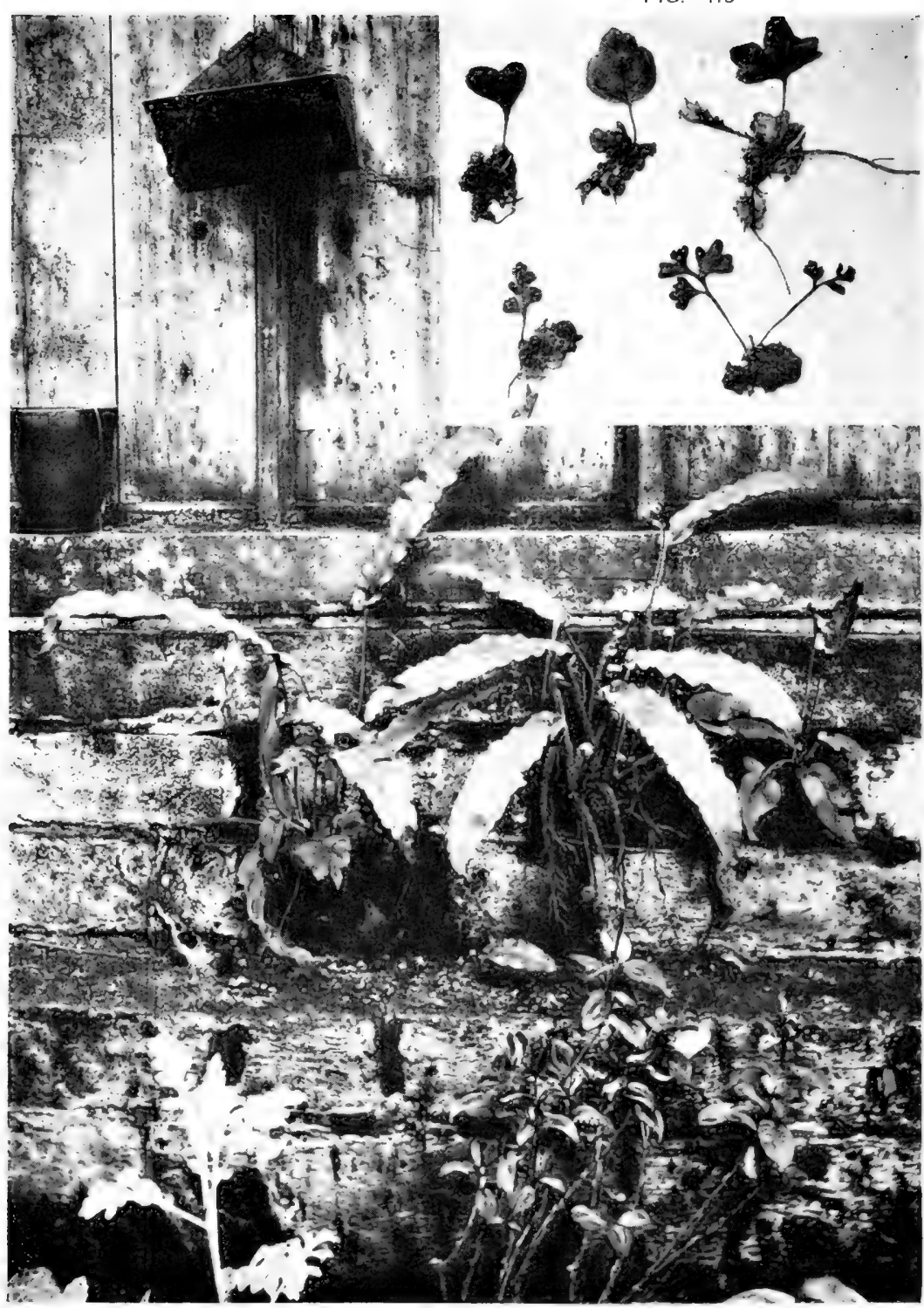

FIG. 110.-GERMINATING FERNS

FIG. 121.-HART'S-TONGUE FERNS GROWING FROM BETWEEN BRICKS OF A WALL 


\section{CHAPTER XVIII}

\section{FERNS (Filices)}

THE subject of ferns hardly comes within the scope of this little volume, whose main purpose is to deal with familiar flowering plants, either wild or cultivated. I am, however, devoting the concluding pages to the consideration of the ferns, because, in the first place, they are undoubtedly familiar plants, and in the second place, they represent the highest order of Cryptogamia or Flowerless plants, in contradistinction to the Phanerogamia or Flowering plants.

In the former chapters we have seen that flowers are specially organised buds produced by plants exclusively for the one purpose of reproduction, or the formation of their seeds. It is obvious, therefore, that a flowerless plant does not produce seeds; flowerless plants are therefore called "spore-plants," and flowering plants "seedplants."

The fructification of ferns may be readily observed on the under sides of their leaves, or fronds. These structures are arranged in various ways; sometimes they appear along the margins of the frond, as in the Bracken (Pteris) genus (Fig. I 6, Plate 84); in other cases, as in the genus Davallia (Fig. I I7, Plate 84) they are enclosed in a 
pocket-like covering at the tips of the frond segments; in still other genera they are seen as isolated bands on the under surface of the fronds, as in the Hart's-tongue Fern (Scolopendrium vulgare), or in spots, which may be covered with a protective scale, as in the common Male Fern (Aspidium Filix-mas), or uncovered as they get older, as in the genus Polystichum (Fig. I 18, Plate $84)$; indeed, the variety of their arrangement is almost endless. The Royal Fern (Osmunda regalis) (or flowering fern, as it is incorrectly called) bears its fructification in clusters on the ends of the fronds, distinct from the leaf-like part ; hence it appears to produce a flowering or fruiting branch.

It is a common idea that each of the little bodies that constitute these brown clusters is the spore, or seed, from which new ferns are developed; but, although they are so small that they generally need a magnifying lens to reveal their individuality, yet each one is a little capsule containing some sixty-four spores. In the enlarged figures shown in the illustrations each little capsule, or spore-case, will be seen to be nearly surrounded with a thickened and annulated band. This band, under atmospheric influence, develops a tendency to straighten out as the capsule dries and matures. Eventually it suddenly uncoils, and so ruptures the walls of the spore-case and, by the sudden explosion, the microscopic spores are discharged into the atmosphere like a tiny puff of smoke. 
PLATE 86

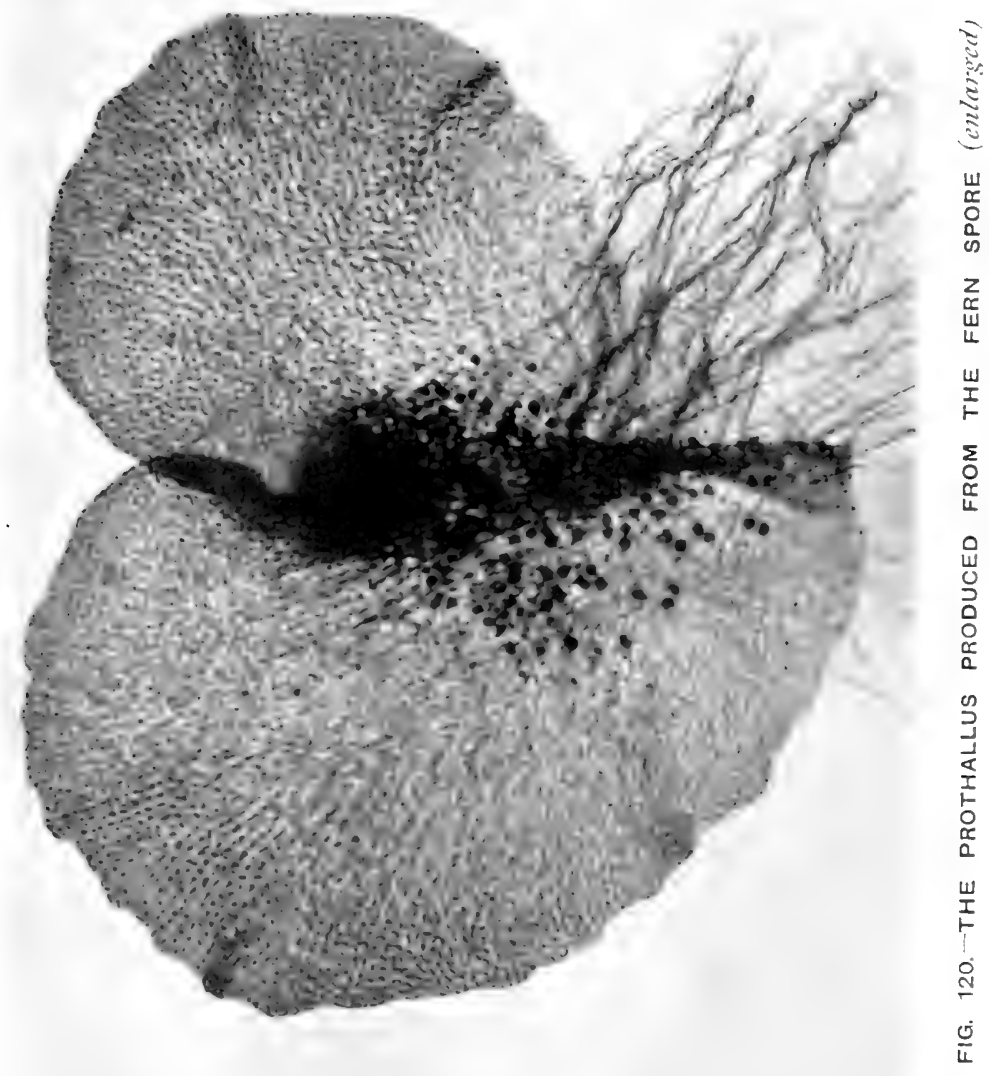





\section{FERNS}

The spores are so minute and light that, in a dry atmosphere, they get wafted for considerable distances. By this means, too, they land in all sorts of curious situations; thus we frequently find ferns growing from the mortar between the bricks of a wall (Fig. I21, Plate 85); or from the bark of the shaded branches of trees that overhang rivers and moist places, and in other similar positions. The most remarkable fact, however, is that these spores, when they develop, do not produce ferns; indeed, the structures that originate from them are something altogether different.

When the tiny spore reaches a damp and warm place with plenty of light, it sends out a tubular development which extends its tissues by division of its cellular structure; first it increases in length, and later transversely. Ultimately, by the continual division of the cells of which it is composed, a flat plate of green tissue is produced. This little heart-shaped structure, known as the prothallus, develops on its under surface delicate "root-hairs," which attach it to the soil. A magnified view of the whole structure is shown in Fig. I 20 (Plate 86).

Thus we see the fern spore produces not a fern, but a little plant-like structure consisting of a heart-shaped green scale which rests upon the surface of the soil, and which in actual size is scarcely one-fifth of an inch in diameter; yet its green tissues can absorb gaseous food from the atmosphere, and its tiny root-structures can supply all its needs from the soil.

This curious little structure exists perhaps for 195 


\section{LIFE HISTORIES OF FAMILIAR PLANTS}

several months as such, and seems to make little or no progress; however, during this time there are mysterious happenings beneath its green frond. Soon after the tissues have completed their growth in area, some of the cells, in a thickened part of the frond near the notch in its upper part, begin to develop into curious flask-like structures that stand out from the surface. Then lower down some rounded bodies appear; Fig. I 20 (Plate 86), just shows the distinction between these structures, but it needs high powers of the microscope to study their details.

Marvellous though it may seem, these are the "ovaries" and "stamens" of the fern-its reproductive parts. Under this little green scale, just visible to the eye, fertilisation has to take place. The rounded bodies are known as antheridia, and they produce within them a large number of extremely minute, spirally-coiled sperms, termed antherozoids. These little organisms are provided with a tuft of delicate cilia by means of which, when they are in water or in moist situations, they are endowed with locomotion, wriggling like eels, as they appear in myriads from the mature antheridia.

At the time they appear, the flask-shaped structures (archegonia) secrete an acid fluid from their mouths, which attracts the lively antherozoids as they plunge about amongst the dew and moisture beneath the prothallus; thus they find their way into the interior of the archegonium and unite with the egg-cell; in that manner fertilisation 


\section{FERNS}

is effected, and the egg-cell becomes a spore that will, on development, produce a fern.

Thus, to put the matter briefly, the spores that fall from the familiar spore-cases attached to the fronds of the fern, give origin to a prothallus whose function is that of producing and maturing the sexual parts ; fertilisation results in the formation of a spore-body which, by division of its cells, gives birth to the fern plant. The prothallus supports the young fern until it has a tiny frond and roots of its own. In Fig. II9 (Plate 85) is shown some "seedling" ferns bearing their first frond and while still attached to their prothalli.

How different are the marriage methods of the humble Cryptogams, or Flowerless plants, from those that have been described in the highlydeveloped Phanerogams or Flowering plants! Yet in that remote period of the earth's history which the geologist terms the "Carboniferous Age," these Flowerless plants were the dominating form of vegetation, just as Flowering plants are in the present day. Twice as many species have been found preserved in the English Coal Measures as can now be found living in the whole of Europe. Once the ferns formed a great race in the plant world, and many of their species reached gigantic proportions; but to-day they are a decaying family, a family that has lost heavily in the struggle for existence, and has been driven from the best situations in the sunlight to the shaded woods and secluded spots which the higher and better developed plants now scorn. 


\section{LIFE HISTORIES OF FAMILIAR PLANTS}

In the day of the ferns, the pollen- and nectarseeking insects had to make their advent; and from thence throughout the ages, by their selective agency, have been instrumental in moulding from lowly types the complex floral structures such as we have glanced at in the earlier chapters of this work. How well they have performed their function only the evolutionary botanist can properly appreciate; however, I trust that this little volume will help to make clear to the general reader a few of the steps in that wonderful process. 


\section{INDEX}

A

Aconitum Napellus, 185

Alder catkins, 56

flowers, 27

Anemone, Buttercup origin of, 177, I7 8

Coloured sepals of, 178-180

-, Nectaries of, 180

Angelica sylvestris, rgo

Angelica, Wild, and insects, 190 -

Animals, Defensive tactics of, 58,59 , Grazing, and sensitive plants, $60,6 x$

Ants and hairs of plants, 177 honey, 8

Aquilegia vulgaris, 182

Arum and midge-flies, 33, 35-43

berries, 44,45

Common, 32

Cross-fertilisation of, 41

Inflorescence of, $34,35,37-39$

, Intoxicating nectar of, 41

Leaves of, 34

maculatum, 31

Midge-flies entrapped in in. florescence of, 40

Pollen of, $4 \mathrm{I}, 42$

, Purple club of inflorescence, $39,42,43$

Start in life of, 33,34

Temperature within inflores cence of, 36

, Tubers of, 34

Ash, Flowers of, 56

Aspidium Filix-mas, 194

\section{B}

Bamboos, Flowers of, 147

Barberry, Gripping powers of sta mens of, $7 \mathrm{I}$

Sensitive stamens of, 70

Stamens and pollen of, 7 I
Bee and catkins, 50, 5 I

- Primrose, 78-81

- - Proboscis of, 80

Bees and nectar, 13

Beetles in Barberry flowers, 70-72

Birds and Arum berries, 45

Bird's-eye Primrose, 75

Bird's-foot Trefoil, 9I

- Floral arrangement of, 152

Bracken, Fructification of, 193

Bramble, 6, 9, Io

Bramble Flower, Structural details of, 4

Briza media, 143

Broom, Branches of, with leaf functions, 89

- Flowers of, 90

-_, Golden yellow of, 85

$\longrightarrow$, Leaves of, $85,86,88,89$

- Protection of, against animal attacks, 89, 90, $9^{2}$

Bryony, Sensitive tendrils of, 69

Buttercup, 6, 9, 10

Bulbous, flowers and roots, 173 , 177

- Details of flower, 4

_- Features of typical, 178

_. Meadow, 173

species, I74

Buttercups and fivefold flowers, I72 and pollen-eating insects, 179

Obsolete nectaries of, 180

Origin of species of, 185

, Reduction in number of ovaries of, 182,183

_, Suppression of petals of, 178

\section{C}

Cacti and animal attacks, 100, 101 Leaves of, 98-100

, Offshoots of, conveyed by animals, rol

, storing water in tissues, 99

Caladium, 102

$$
\text { , Large leaves of, } 102
$$




\section{INDEX}

Camomile, Wild, and Field Daisy at night, 15,16

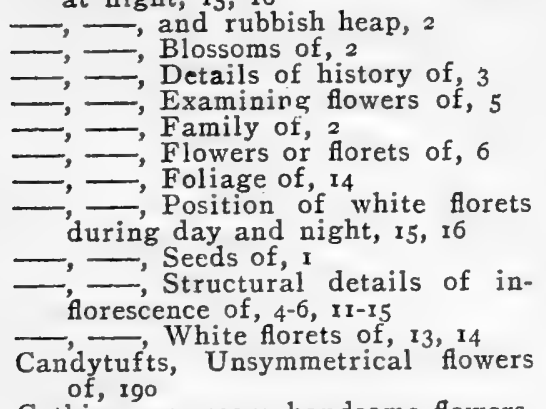

Catkins once more handsome flowers, 50,123

_- See also Alder, Bee, Hazel, and "Palm"

Cattleya citrina, 104

Centaurea Cyanus, 191

Christmas Rose, Buttercup origin of, I77, 178

Clematis, Coloured sepals of, $178-180$

- Obsolete nectaries of, 180

Clover, Dutch, and insect guests, 155

- - Creeping stems of, 156 - 156 , Flower-heads of, ${ }_{151},{ }_{155}$

$\longrightarrow$ - - Seed pods of, 156

- flowers and bee, I54, 156 leaves, 86

- - Subterranean, a highly-evolved plant, 159 ,$- \frac{158}{15}$, sowing its seed pods, 157 ,

Clovers and Pea-flower family, 150,

- ${ }^{15 I}$ Colour of flower-heads of, 154

Evolution of, $152,153,154$

Coltsfoot and competitors, 107, II2

- and railway cutting, 113,116

— and soil, 107-109

_ and the farmer, 106, 107, I10, II7

--, Credentials of, 108

_. Cross-fertilisation of, III

- Florets of, III

- Flower-heads of, 106, 108, 111, I12, 114

- Flowering stem and scales of, IIO

guarding its pollen, II2

leaves and sunlight, 114-116

$\longrightarrow$ and woolly hairs, I16

—, Seeds of, 107, 108, II3

- Suppression of function of ovary of, III

- Underground branches of, Iro, I I 4,115

Columbine, Nectaries of, 182
Columbine, Stamens and stigmas of, 182

Comfrey, Ligules of, 171

Cornflower, Neuter florets of, 191

Corn Marigold, 3

Cowslip and insect visitors, 77

- Flower-stalk of, 74, 75

- Pendulous flowers of, 76

Crocus family, Evolution of, 168

Cryptogamia, 193, 197

Cuckoo-pint, 32

Cytisus laburnum, 84, 96

\section{D}

Daffodil and humble-bee, 169

-, Cross-fertilisation of, 170

-, Evolution of floral crown of, 170,171

_ family and inferior ovary, 167

- - Evolution of, 167,168

Daffodils and Lilies, 166-168

Daisies lasting as cut "flowers," 13

- mimicking a single flower, 14

Daisy, Field, 3

- inflorescence and bee, 12-14

- tribe's inflorescence, 4

Darwin and cross-fertilisation, 6

and flowers of Orchis, 136

- and nectary of Orchis, I4I

- and Primrose, 76, 79

Davallia, Fructification of, 193, 194

Delplinium elatum and cross-fertilisation, 185,186

Dicotyledons, $164,171,172$

Dog-rose, 6, 9, 10

, Details of flower of, 4

"Double" flowers, 9

\section{E}

Elm, Flowers of, 56,57

Evening Primrose, Pollen tubes of, 55

F

Fern, Antheridia of, 196

-, Archegonia of, 196

- Fructification of Hart's-tongue, 194

Male, 194

_- Prothallus of, 195-197

- Reproductive parts of, 196, 197 


\section{INDEX}

Ferns, Fructification of, 193, 194 Germination of spores of, 195 in Carboniferous Age, 197 Spore capsules of, 194

Fertilisation, Wind- and insect-, 54

Feverfew Chrysanthemum, 3

Flies and Sycamore flowers, 24-27

Floral structures and insect agency, 198

Flower, Parts of a, 4, 37, $3^{8}$

Flowers, Abortive, 39

and wind-fertilisation, 18I

"Double," 9

-, Minute, Grouping of, II, 13, I52, I9I

of forest trees, 47,48

- Simplest forms of, 38

Foxglove, Cross-fertilisation of, 187 flowers and bee, 10, 11, 186, 187

- inflorescence and Camomile Daisy compared, II, 12

One-sided raceme of, 186,187

Fruit as evidence of flower, 47

Fruits, Reduction in number of, 159, 182,183

\section{G}

Gladiolus, Flower of, 168

Globe-flower, Buttercup origin of, 177,178

- Nectaries of, $x 79$

Gorse as fodder, 92, 93

branches with leaf functions, 94

Evolution of, 90-94

Leaves of, $86,93,94$

Grasses and wind-fertilisation, 143 Evolution of, 148, 149

Guelder Rose, Enlarged neuter flowers of, 191

\section{$\mathbf{H}$}

Hazel catkins, 48

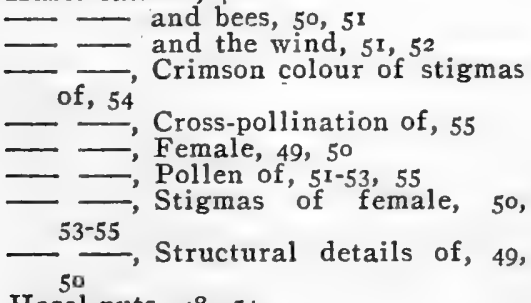

Hazel-nuts, 48, 54

Hedgehog and sense of touch, 58-60
Hedge-nuts, 48, 54

Hellebore, Garden, Nectaries of, 179 - Green, Buttercup origin of, I77, 178

Honeysuckle flowers and hawk-moths I88, 189

-

\section{I}

Insects and composite flowers, 14

- and cross-pollination, ?

- and plants, Reciprocal evolution of, 28,198

- eating pollen, 7

Iris family, Evolution of, 168

K

Kidney Vetch, 92

- Floral arrangement of, 152

\section{$\mathbf{L}$}

Laburnum, Evolution of, 87

- Flowers of, 87,88

-, Inflorescence of, $150-152$

- Leaves of, $85-87$

Larkspur and bee, 184 -, Evolution of floral parts of, 183 183

Livelong, or Orpine, Nectar of, 160

Lonicera Caprifolium, 188

Lords-and-ladies, 32

Lychnis, Red, Ligules of, 170

, White, Ligules of, I7o

\section{M}

Marigold, Marsh, Buttercup origin of, 177,178

,,-- Coloured sepals of, $x 78$

- Nectaries of, 180

Matricaria Chamomilla, I

Meadow Rue, Columbine-leaved, Showy stamens of, 18I Lesser, Wind-fertilisation of, $18 \mathrm{I}$

Midge-flies and Arum inflorescence, $33,35-43$ 


\section{INDEX}

W

Wake-robin, 32

Wall-pepper, Flowers of, 160,165 $\overrightarrow{\text { Water Buttercup and hairs, } 177}$ 177 , Colour of petals of, 176,

-177
Water Dock, Leaves of, 102

Water Lilies, Leaves of, 102, 116, 176 Water Lily, White, and sun-loving insects, 189

Willow, Flowers of, 27, 28 , "Palm" (see "Palm" Willow) Willows, British, 119, 125

Wind-pollination, $7,51-54,144-146$ Wood-sorrel, Drooping leaflets of,

"Woolly bear" and sense of touch, 58-60

Printed by Cassell \& Company, Limited, La Belle Sauvage, London 2 E.C. 




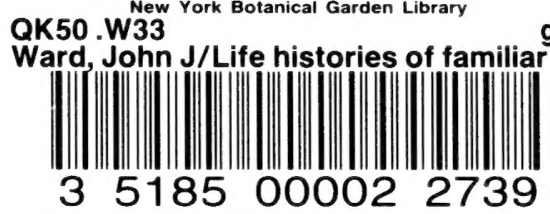


$\div$

5

is

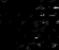

$\because$

$\ldots$

E

\%

$-$ 